\title{
Lithostratigraphy of the Upper Oligocene - Miocene succession of Denmark
}

Erik Skovbjerg Rasmussen, Karen Dybkjær and Stefan Piasecki 


\section{Geological Survey of Denmark and Greenland Bulletin 22}

\section{Keywords}

Lithostratigraphy, Miocene, Upper Oligocene, North Sea, Denmark

\section{Cover}

Upper shoreface sands of the Billund Formation in the Addit gravel pit, central Jylland showing prominent burrows (Ophiomorpha isp.); illustrated section is $40 \mathrm{~cm}$ high. Photo: Tom Pallesen.

\section{Frontispiece}

Outcrop of the Kolding Fjord Member, Klintinghoved Formation at Hagenør, Lillebælt. The succession is dominated by organic-rich, lagoonal, silty clay and sand beds deposited as washover fans on the back-barrier flat. Photo: Peter Warna-Moors.

Chief editor of this series: Adam A. Garde

Editorial board of this series: John A. Korstgård, Department of Earth Sciences, University of Aarhus; Minik Rosing, Geological Museum,

University of Copenhagen; Finn Surlyk, Department of Geography and Geology, University of Copenhagen

Scientific editor of this volume: Jon R. Ineson

Editorial secretaries: Jane Holst and Esben W. Glendal

Referees: Dan Evans (UK) and Claus Heilmann-Clausen (DK)

Illustrations: Stefan Sølberg

Digital photographic work: Benny M. Schark

Layout and graphic production: Henrik Klinge Pedersen

Printers: Rosendahls · Schultz Grafisk a/s, Albertslund, Denmark

Manuscript received: 15 December 2009

Final version approved: 1 November 2010

Printed: 31 December 2010

ISSN 1604-8156

ISBN 978-87-7871-291-2

\section{Citation of the name of this series}

It is recommended that the name of this series is cited in full, viz. Geological Survey of Denmark and Greenland Bulletin.

If abbreviation of this volume is necessary, the following form is suggested: Geol. Surv. Den. Green. Bull. 22, 92 pp.

\section{Available from}

Geological Survey of Denmark and Greenland (GEUS)

Øster Voldgade 10, DK-1350 Copenhagen K, Denmark

Phone: +45381420 00, fax: +45381420 50, e-mail: geus@geus.dk

or at www.geus.dk/publications/bull

(C) De Nationale Geologiske Undersøgelser for Danmark og Grønland (GEUS), 2010

For the full text of the GEUS copyright clause, please refer to www.geus.dk/publications/bull 



\section{Contents}

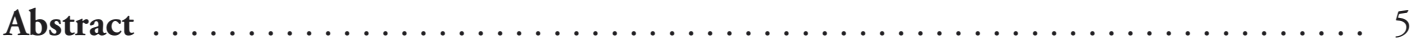

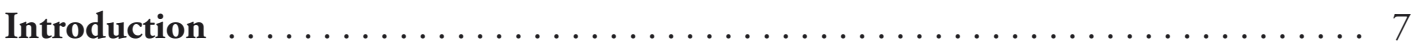

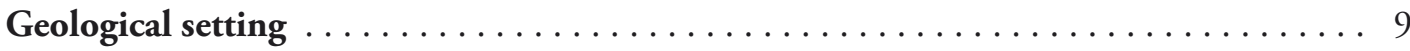

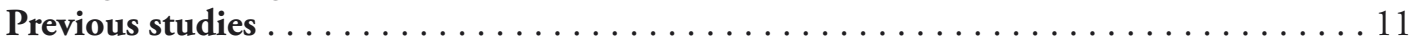

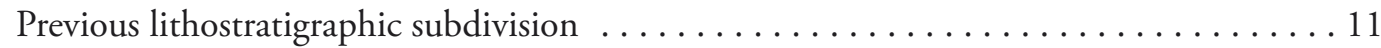

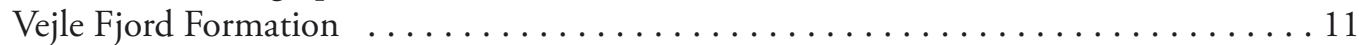

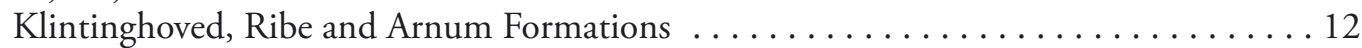

Arnum, Hodde, Gram and Sæd Formations . . . . . . . . . . . . . . . . . . . . . . . 12

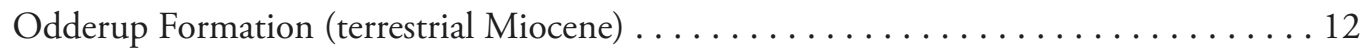

Sequence stratigraphy and onshore-offshore correlation $\ldots \ldots \ldots \ldots \ldots \ldots \ldots$

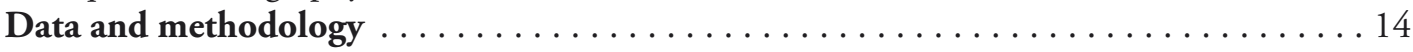

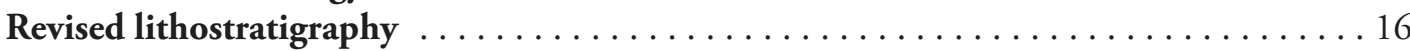

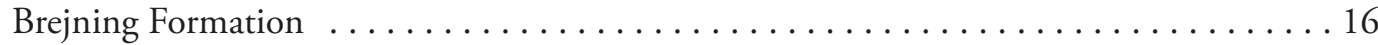

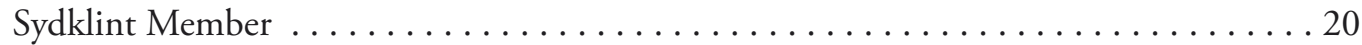

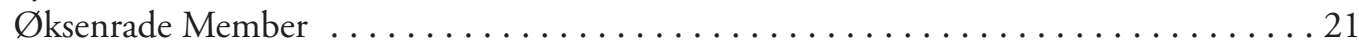

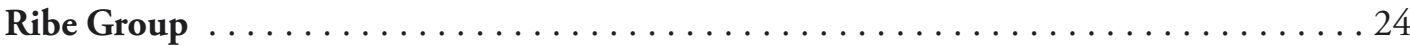

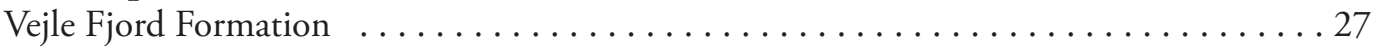

Skansebakke Member ................................... 32

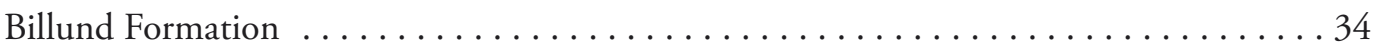

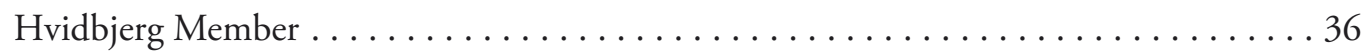

Addit Member . . . . . . . . . . . . . . . . . . . . . . . . . 40

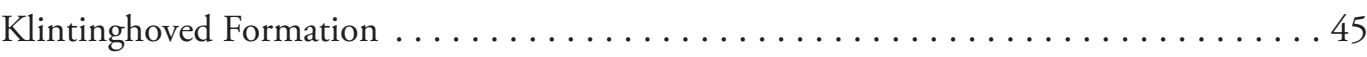

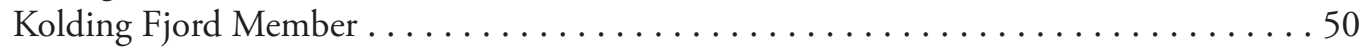

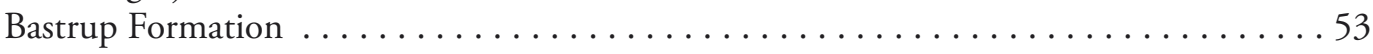

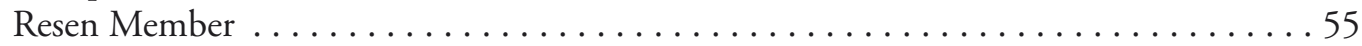

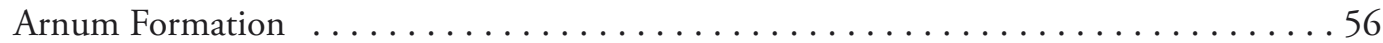

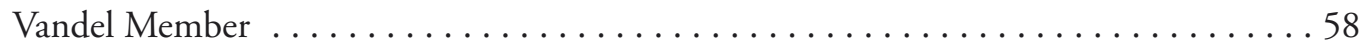

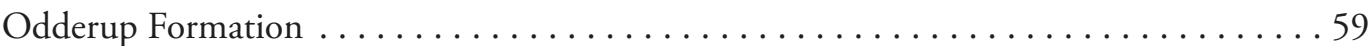

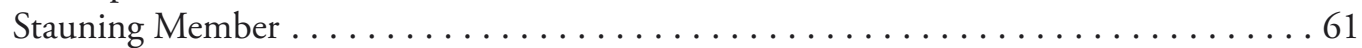

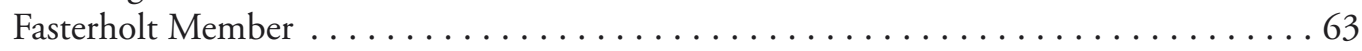

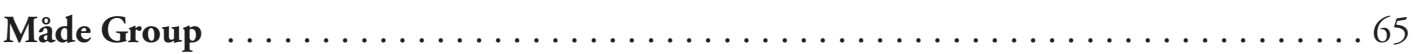

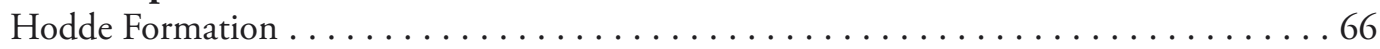

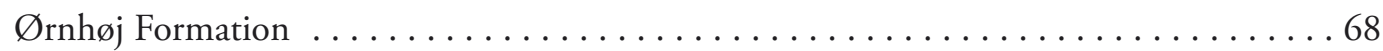

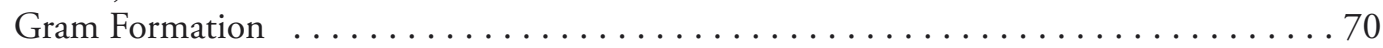

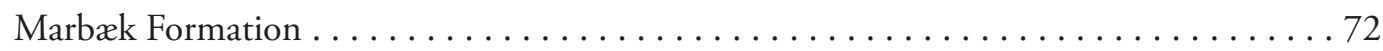

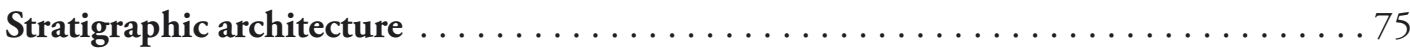

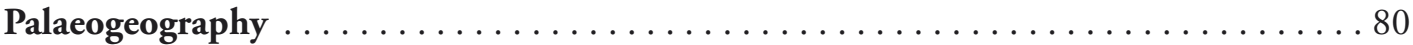

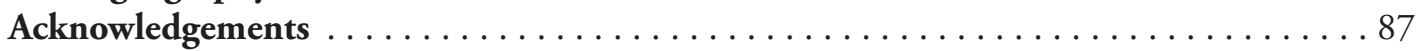

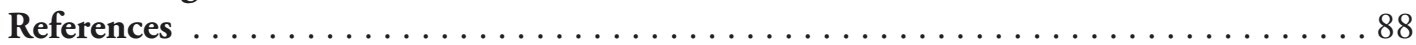




\section{Abstract}

Rasmussen, E.S., Dybkjær, K. \& Piasecki, S*. 2010: Lithostratigraphy of the Upper Oligocene - Miocene succession of Denmark. Geological Survey of Denmark and Greenland Bulletin 22, $92 \mathrm{pp}$.

This paper presents a revised lithostratigraphic scheme for the uppermost Upper Oligocene - Miocene succession of Denmark. The marine Oligocene Brejning Clay Member is upgraded to formation status and includes the Sydklint Member and the Øksenrade Member (new). The shallow marine and deltaic deposits of mainly Early Miocene age are included in the Ribe Group (new) while the fully marine Middle and Upper Miocene clay-rich deposits are referred to the Måde Group (new). The Ribe Group is subdivided into 6 formations: the Vejle Fjord Formation is revised and includes the Skansebakke Member, the Billund Formation (new) includes the Addit and Hvidbjerg Members (new), the Klintinghoved Formation is redefined formally and includes the Koldingfjord Member (new), the Bastrup Formation (new) includes the Resen Member (new), the Vandel Member is a new member in the Arnum Formation (revised), the Odderup Formation is redefined and includes the Stauning Member (new) and the coalbearing Fasterholt Member. The Måde Group is subdivided into the Hodde, Ørnhøj (new), Gram and Marbæk (new) Formations. Subdivision of the Upper Oligocene - Miocene succession into two groups, the Ribe and Måde Groups, is compatible with the North Sea lithostratigraphic framework where they correlate with the upper part of the Hordaland Group and the Nordland Group, respectively.

The revised lithostratigraphic framework correlated in three dimensions provides rigorous constraints on the palaeogeographic interpretation of the Late Oligocene - Miocene period. Three major deltaic units (Billund, Bastrup and Odderup Formations) prograded from the north and north-east into the North Sea Basin during the Early - early Middle Miocene. Delta progradation was punctuated by deposition of marine clay and silt associated with minor transgressive events (Vejle Fjord, Klintinghoved and Arnum Formations). During the Middle-Late Miocene, marine depositional conditions dominated (Hodde, Ørnhøj and Gram Formations). A fourth and final progadational event (Marbæk Formation) commenced in the latest Tortonian heralding the emergence of present-day Denmark (including the North Sea sector).

\footnotetext{
Authors' address

Geological Survey of Denmark and Greenland, Øster Voldgade 10, DK-1350 Copenhagen K, Denmark.

E-mail: esr@geus.dk

*Present address: University of Copenhagen, Øster Voldgade 10, DK-1350 Copenhagen K, Denmark.
} 


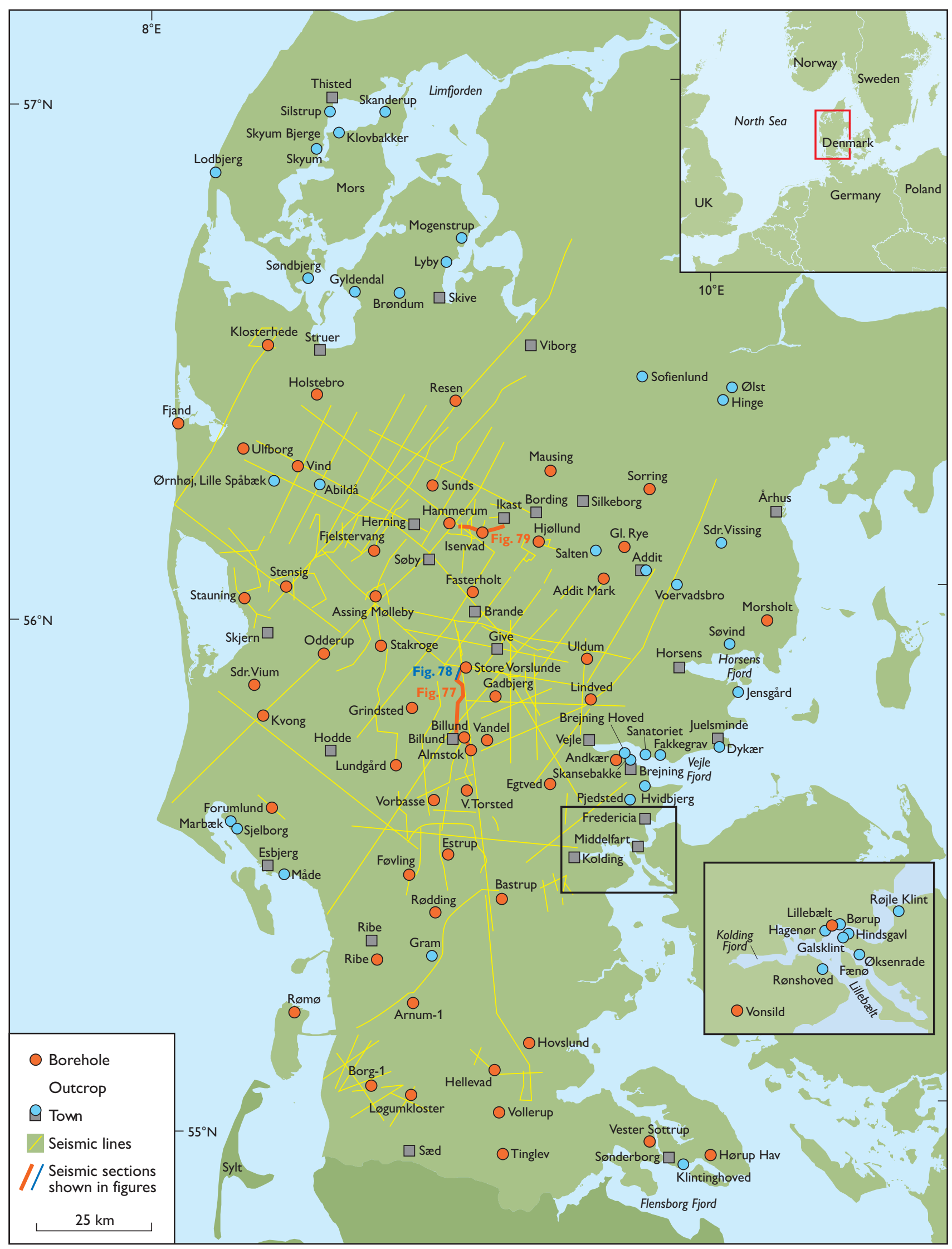

Fig. 1. Map showing the location of the study area in Jylland, western Denmark, and the boreholes, outcrops and seismic data used. Towns and villages mentioned in the text are indicated. The index map (lower right) shows the localities in the Fredericia-Kolding area. 


\section{Introduction}

Sediments of Miocene age crop out in Denmark along the east coast of Jylland and in the Limfjorden area (Fig. 1); a few inland cliffs in central Jylland also expose Miocene deposits, especially in river scars and road cuts. Excavation for raw materials for construction, i.e. gravel, sand and clay, has resulted in open pits that expose Miocene deposits, mainly in western and central Jylland. During the last decade, the increasing need for water for domestic purposes and irrigation has initiated intensive drilling programs and the acquisition of high-resolution seismic data from the Miocene succession. The renewed interest in the Miocene has resulted in financial support for field investigations, so it has been possible to re-study all Danish outcrops exposing Miocene deposits.

A high-resolution biostratigraphic subdivision of the Miocene succession has been developed, based on dinoflagellate cysts (dinocysts) (Dybkjær \& Piasecki 2010). This new dinocyst zonation has provided a robust framework within which the studied boreholes have been correlated. It has also made it possible to integrate all seismic and borehole data with the new, detailed sedimentological descriptions and interpretations of the outcrops (Friis et al. 1998; Rasmussen \& Dybkjær 2005; E.S. Rasmussen et al. 2006) in order to construct a depositional model for the Miocene succession. Associated studies, for example of the climatic conditions (Larsson et al. 2006; Larsson-Lindgren 2009; T. Utescher, personal communication 2009) and sediment provenance (Knudsen et al. 2005; Olivarius 2009), have further added to the understanding of the depositional system.

The lithostratigraphy presented here encompasses the upper Upper Oligocene- Miocene succession found onshore Denmark. It is bounded beneath by a major unconformity between Upper Eocene - lower Upper Oligocene clay-rich deposits and silt- and sand-rich deposits of late Late Oligocene - Miocene age. The top of the successsion is defined by the Quaternary unconformity. During the study of the succession, it was necessary to establish a number of informal lithostratigraphic units that are now widely used in the mapping of aquifers both in Denmark and Germany, and are increasingly adopted in the literature (Rasser $e t$ al. 2008; Knox et al. 2010). It is therefore timely to formally define these units and redefine existing lithostratigraphic units in order to construct a consistent lithostratigraphic framework.

The Miocene succession was deposited during a period of worldwide tectonism (Potter \& Szatmari 2009) and marked climatic change (e.g. Zachos et al. 2001; Miller et al. 2005; Utescher et al. 2009). Two of the most distinct phases in the Alpine orogeny commenced in the Miocene, the Late Oligocene - Early Miocene Savian Phase and the Middle Miocene Betic Phase (Ziegler 1982; Oszczypko 2006; Ribero et al.1990). The opening of the North Atlantic was characterised by the final change in spreading from the Aegir Ridge to the Kolbeinsey Ridge and increasing spreading rates in the Early Miocene have been detected (Mosar et al. 2002; Doré et al. 2008). In the Middle Miocene, a major tectonic reorganisation occurred (Ziegler 1982; Doré et al. 2008). The climate was warm temperate in the Early - early Middle Miocene, but changed to a cold temperate climate in the Late Miocene.

The Miocene succession studied here was deposited in the eastern part of the North Sea Basin (Fig. 2). The onshore portion of this basin under focus here is a stratigraphically complete fluvial - deep shelf transect that is recorded in detail by outcrop, borehole and seismic data; it provides a natural laboratory for the study of the development of fluviodeltaic depositional systems, the tectonic impact on basin evolution and the consequences of climatic changes including glacio-eustatic sea-level changes. In addition to creating a robust and consistent framework for practical applications, therefore, the lithostratigraphic revision presented here is a prerequisite for future research into Miocene climatic, tectonic and eustatic evolution. 


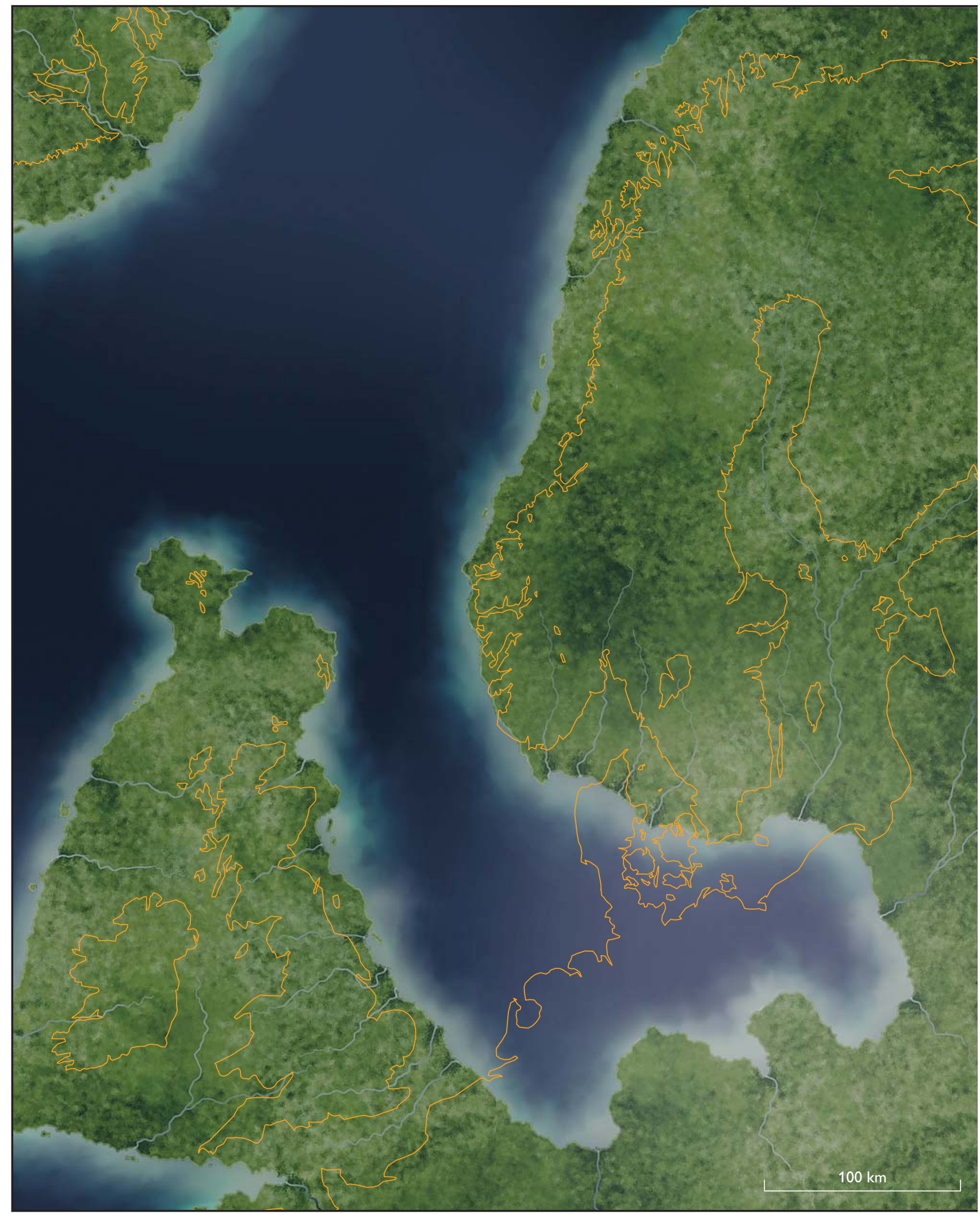

Fig. 2. Palaeogeographic reconstruction of North-West Europe during the Early Miocene (modified from E.S. Rasmussen et al. 2008); configuration based on Mosar et al. (2002). 


\section{Geological setting}

The evolution of the North Sea Basin was strongly influenced by the collision between the African and European tectonic plates, volcanism in central Europe and the opening of the North Atlantic (Ziegler 1982; 1990; Ziegler et al. 1995; Martinsen et al. 1999; Faleide et al. 2002; E.S. Rasmussen et al. 2005, 2008; Rasmussen 2009a; Gabrielsen et al. 2010). Interaction of these factors with changing eustatic sea level resulted in final closure of the southern connection with the Tethyan ocean during Early-Middle Miocene times (Harzhauser \& Piller 2007); subsequently, the only connection to the Atlantic was through a strait between Norway and Shetland (Fig. 2).

The depositional basin of the eastern North Sea area which covered present-day Denmark, was bounded towards the north-east by the Fennoscandian Shield (Fig. 3; Bertelsen 1978; Vejbæk 1997). The transition to the basin was controlled by the SE-NW-trending Sorgenfrei-Tornquist Zone. The basin was subdivided into two subbasins: the Norwegian-Danish Basin and the North German Basin, with the ESE-WNW-striking Ringkøbing-Fyn High separating the subbasins. The Ringkøbing-Fyn High is further segmented into a number of $\mathrm{N}-\mathrm{S}$-trending elements such as the Brande Trough (Fig. 3). These structural elements were formed during Permian rift tectonics and later reactivated in the Jurassic and during Late Cretaceous and Early Paleocene inversion tectonics (Ziegler 1990; Liboriussen et al. 1987; Mogensen \& Jensen 1994; Vejbæk $\&$ Andersen 2002). Reactivation of some of the older structures occurred in the Oligocene as well as in the Miocene (E.S. Rasmussen 2004a, 2009a; Japsen et al. 2007). During the Middle Miocene, the North Sea Basin experienced increased regional subsidence (Ziegler 1982, 1990; Vejbæk 1992; Koch 1989; Michelsen et al. 1998; Clausen et al. 1999; E.S. Rasmussen 2005). In the late Pliocene - early Pleistocene, the North Sea Basin was tilted towards the southwest (Japsen 1993; Japsen \& Bidstrup 1999; Japsen et al. 2002; E.S. Rasmussen et al. 2005).

The North Sea Basin was located in the northern westerly wind belt. The climate was warm temperate to tropical in the early part of the Paleogene (Buchardt 1978; Heilmann-Clausen \& Surlyk 2006; Zachos et al. 2001). A dramatic change occurred at the Eocene-Oligocene transition where a distinct climatic cooling took place. The early Oligocene icehouse climate resulted in a marked eustatic sea-level drop due to growth of ice caps, primarily on Antartica (Buchardt 1978; Prentice \& Matthew 1988; Miller et al. 1991, 1996, 1998, 2005; Zachos et al. 2001).

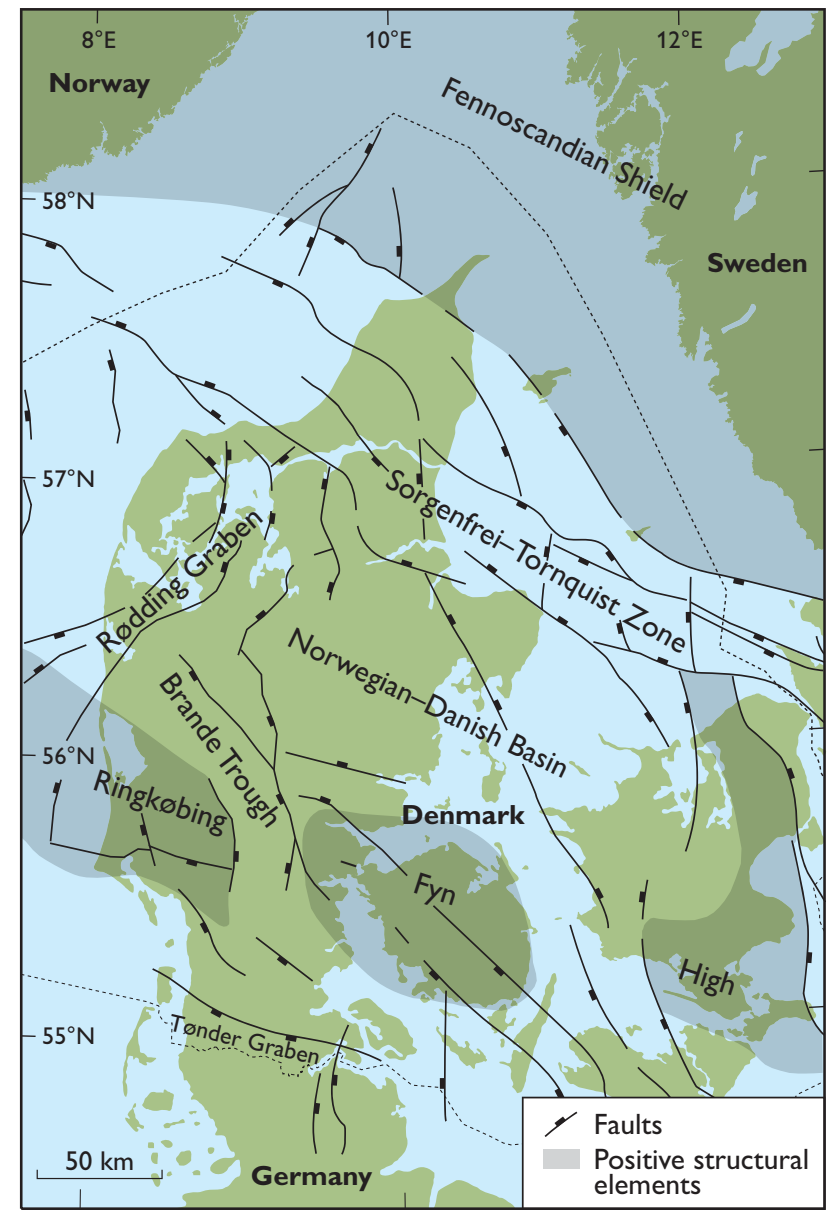

Fig. 3. Structural elements in the study area. Modified from Berthelsen (1992).

However, by the end of the Oligocene a subtropical climate prevailed in the North Sea Basin area (T. Utescher, personal communication 2009; Larsson et al. 2010). At the boundary between the Palaeogene and the Neogene, a marked, but transient, climatic cooling occurred with buildup of widespread ice caps on Antarctica. This climatic event resulted in a major, global sea-level fall (Miller et al. 1998; Zachos et al. 2001). The Early Miocene climate in the North Sea Basin area was characterised by an oscillation between cool temperate and warm temperate climates (Mai 1967; Larsson et al. 2006). An overall increase in temperature culminated at the Early to Middle Miocene transition, the so-called 'Mid-Miocene climatic optimum' (Buchardt 1978; Zachos et al. 2001). In the North Sea Basin area, a warm temperate to subtropical climate prevailed (Mai 1967; Friis 1975; Utescher et al. 2000, 2009). 


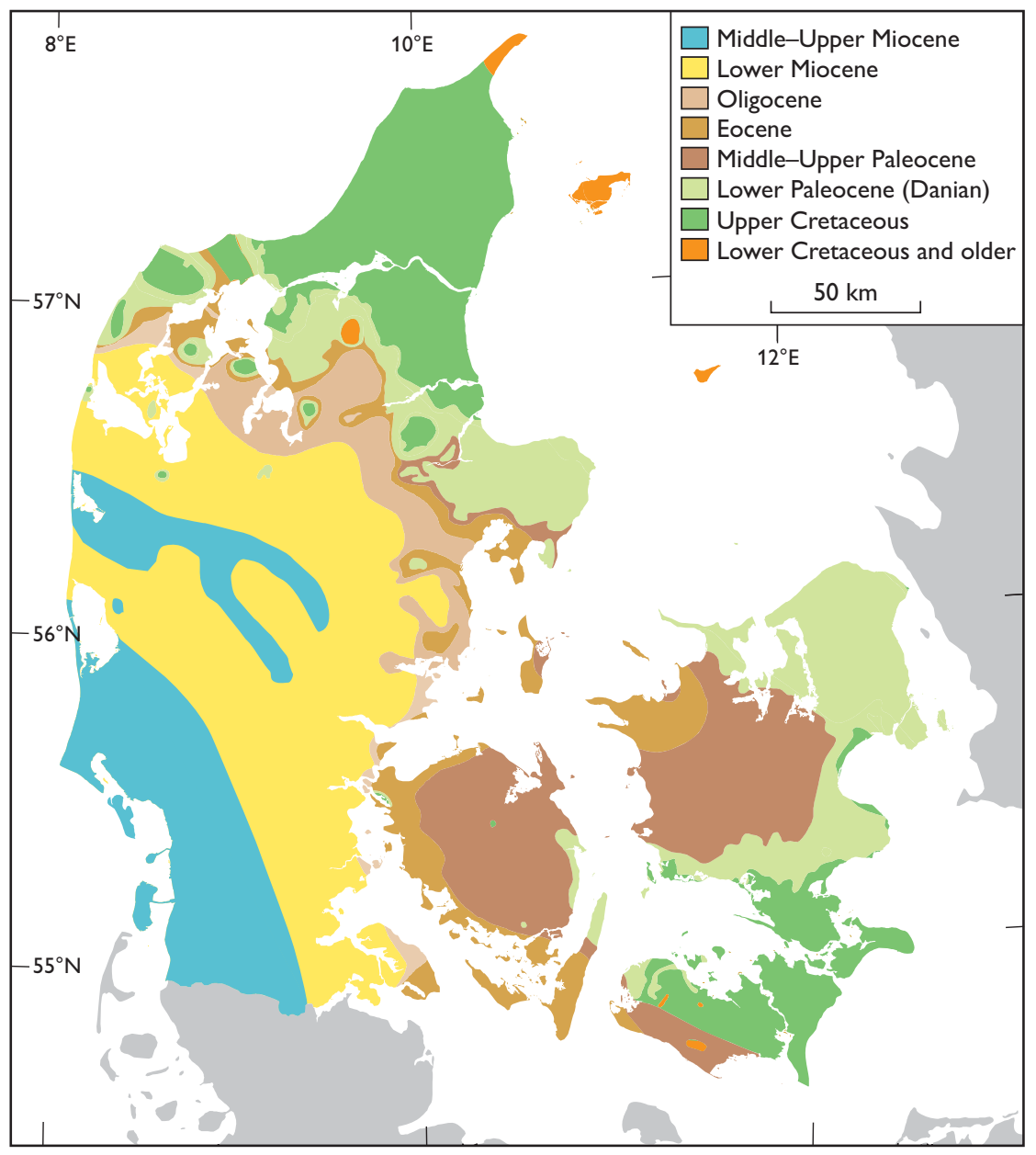

Fig. 4. Pre-Quaternary subcrop map of Denmark. Modified from Sorgenfrei \& Berthelsen (1954) and Håkansson \& Pedersen (1992).

At the termination of the Middle Miocene, a marked drop in global temperature commenced and during most of the Late Miocene the North Sea Basin area was characterised by a cool temperate climate (Buchardt 1978; Utescher $e t$ al. 2000, 2009; Zachos et al. 2001; Larsson-Lindgren 2009).

Fine-grained siciliclastic sediments of mainly deep marine origin were deposited in Denmark and the North Sea Basin during the post-Danian Palaeogene (Heilmann-Clausen et al. 1985; Heilmann-Clausen 1995; Schiøler et al. 2007). A general sea-level lowstand and tectonic re-organisation during the Oligocene resulted in erosion or non-deposition, especially in the central and southern part of the study area. In the northern part of the North Sea Basin, prodeltaic, clay-dominated wedges were laid down. In the latest Oligocene, renewed transgression resulted in the deposition of glaucony-rich clay. This was followed by deposition of deltaic and coastal-plain sand and clay in the Early Miocene. Three major deltaic progradational pulses occurred during the Early Miocene; the third and final pulse was characterised by extensive coal deposition. Subsequent to deposition of the dominantly fluvio-deltaic deposits in the Early to early Middle Miocene, full marine, clay-rich sedimentation dominated during the remaining part of the Middle and Late Miocene.

Late Pliocene - early Pleistocene tilting of the eastern North Sea area (Japsen 1993; Japsen \& Bidstrup 1999; Japsen et al. 2002; E.S. Rasmussen et al. 2005), combined with periodic growth of ice caps in the northern hemisphere, resulted in base-level fall and marked erosion of the substratum; Middle and Upper Miocene deposits are thus missing in the eastern and northern parts of Jylland (Fig. 4). 


\section{Previous studies}

J.G. Forchhammer (1794-1865) wrote the first account of the geology of Denmark (Forchhammer 1835; see also Garboe 1961) and described the Diluvial 'Rullestensdannelse' (loosely translated as 'boulder formation') which he recognised throughout Denmark; this unit was partly included in the Tertiary. The lower part was named the 'amber-brown-coal formation' (translated from Danish) and included fossiliferous strata of 'the western system', which was recognised in west and central Jylland as well as farther south in Germany, for example on the island of Sylt (Fig. 1). This 'western system' undoubtedly included the marine Miocene as recognised today. Beyrich (1853) studied molluscs collected by Forchhammer from Sylt and informed Forchhammer in 1854 that he had identified these as a Miocene fauna (Garboe 1961). Molluscs from south-west Jylland (e.g. Esbjerg and Gram) were also identified as being of Miocene age, and the results were presented at the 11th Scandinavian Research Meeting in Copenhagen in 1873 (Mørch 1874).

The palaeontologist J.P.J. Ravn (1866-1951) established the first Miocene (and Oligocene) stratigraphy of Denmark based on his comprehensive study of the fossil faunas in dark brown and grey, mica-rich clay which occurred widely in Jylland. The resulting stratigraphic scheme of the Lower, Middle and Upper Miocene and associated deposits (Ravn 1906) was published one year before his monograph on the Oligocene and Miocene mollusc faunas (Ravn 1907). Ravn realised that Lower Miocene marine faunas were missing and therefore suggested that the widespread brown-coal deposits represented the Lower Miocene. He also included part of the mica-rich clay and sand succession of the Lillebælt region in south-east Jylland in the Lower Miocene, based on mixed Oligocene-Miocene faunas. The botanist N.E.K. Hartz (1867-1937) studied the succession that includes brown-coal deposits. Exposures of brown coals were scarce at that time, but he concluded that the coals and the associated mica-rich sediments are all freshwater deposits (Hartz 1909) and he found no evidence to contradict the Early Miocene age suggested by Ravn (1906).

The Geological Survey of Denmark (DGU) performed two drilling campaigns in 1917 and 1921 under the leadership of V. Milthers, and more brown-coal deposits were located. Later, on the initiative of K. Milthers, DGU drilled almost 9000 boreholes during the years between 1941 and 1949 (L.B. Rasmussen 1988). In the last campaign (1958-1963), more than 2000 boreholes were drilled, making a total of approximately 11000 boreholes (L.B.
Rasmussen 1988). In addition to engineering data, these extensive programmes also yielded geological results such as the volume, numbers and extent of brown-coal seams. The Middle-Upper Miocene succession was not well understood prior to the Second World War but the second drilling campaign revealed the overall stratigraphy and approximate thickness of these strata (Milthers 1949; Heller 1960). These workers proposed the existence of two discrete coalbearing units (probably broadly equivalent to the Ribe and Odderup Formations of later workers, see below) underlying c. $100 \mathrm{~m}$ of Middle Miocene marine sediments (the Arnum Formation of later workers).

\section{Previous lithostratigraphic subdivision}

Prior to this study, the Upper Oligocene - Miocene succession of onshore Denmark had been subdivided lithostratigraphically into a number of formal and informal units. The origin of these terms is discussed briefly below to provide the background to the lithostratigraphic revision presented in this bulletin.

\section{Vejle Fjord Formation}

The mixed Oligocene-Miocene fauna reported by Ravn (1907) from the Lillebælt region (Fig. 1) impelled Eriksen (1937) to study the same succession in this region for fossils; he found a sparse mollusc fauna in the Brejning exposure on the south coast of Vejle Fjord and in neighbouring cliffs. The fauna in the lower, glauconitic strata was of Oligocene age, but the sparse fauna in the overlying black, micaceous clay was suggested to be of Early Miocene age. The uppermost beds of the succession, comprising micaceous, grey sand, were barren of fossils. Larsen \& Dinesen (1959) studied the same strata in two exposures and formally established the Vejle Fjord Formation which consisted of the glauconitic Brejning Clay and the overlying, black to grey, micaceous clay and sand of the Vejle Fjord Clay and Vejle Fjord Sand, respectively. Analysis of the foraminifer fauna in the Brejning Clay clearly indicated an Upper Oligocene affinity whereas a contrasting foraminifer fauna in the overlying, basal Vejle Fjord Clay was suggested to indicate an Early Miocene age (Larsen \& Dinesen 1959). These data supported the results based on the mollusc fauna, indicating that most of the formation, i.e. the Vejle 
Fjord Clay and Vejle Fjord Sand", should be referred to the Lower Miocene. The Oligocene-Miocene transition was thus placed near the shift from the glauconitic Brejning Clay to the black pyritic clay of the Vejle Fjord Clay.

In the following years, the Vejle Fjord Clay and Vejle Fjord Sand were systematically excluded from most Miocene stratigraphic schemes (e.g. L.B. Rasmussen 1961). It was not until much later that Danish stratigraphers incorporated the Vejle Fjord Formation and the foraminifer stratigraphy in a Miocene stratigraphic scheme, although maintaining the Vejle Fjord Formation and Klintinghoved Formation (see below) as separate geographic entities (Buchardt-Larsen \& Heilmann-Clausen 1988).

Farther north in Jylland, Christensen \& Ulleberg (1973) defined the Sofienlund Formation which was divided into four members: the Ulstrup Clay, the Sofienlund Clay, the Sofienlund Silt and the Sofienlund Sand. The foraminifer content of the Sofienlund Formation suggested a Chattian age for the two lower members and a post-Chattian age for the upper two members (Christensen \& Ulleberg 1973). The lithology and biostratigraphy clearly indicate that these sediments should have been referred to the previously established Vejle Fjord Formation. A similar view was stated by Larsen \& Kronborg (1994), according to whom the lower two members are equivalent to the Brejning Clay whereas the upper two members equate to the Vejle Fjord Clay and Vejle Fjord Sand. The Sofienlund Formation is abandoned herein.

The Sydklint Member was erected in north-west Jylland and provisionally referred to the basal Vejle Fjord Formation by Heilmann-Clausen (1997); this member is re-assigned to the Brejning Formation in this bulletin.

\section{Klintinghoved, Ribe and Arnum Formations}

The fossil mollusc fauna of the Lower and Middle Miocene, exemplified by fauna from the coastal cliff at Klintinghoved and seven deep wells in southern Jylland, was studied by Sorgenfrei (1940, 1958). The Klintinghoved Formation (of present usage) was not defined formally, but arose from extensive palaeontological work on the outcrop of a glacial, dislocated and folded raft of sediments that was considered to be of Early Miocene age (Sorgenfrei 1940). Sorgenfrei (1957) included the 'Klintinghoved Mica Clay' as a formal formation in his 'Formations of Denmark' in Lexique Stratigraphique. Two new formations were defined on the basis of the deep wells, the Ribe and Arnum Formations; the marine clay of the Arnum Formation was referred to the Middle Miocene on the basis of the fauna (Sorgenfrei 1958). The faunally barren Ribe Formation, composed of quartzitic sand, was recorded below the fossiliferous Arnum Formation in one well near the town of Ribe. In the Danish American Prospecting Company (DAPCO) well at Arnum, Sorgenfrei (1958) tentatively referred quartz-rich gravel and sand, below mud and sand of the Arnum Formation, to the Ribe Formation and underlying clays to the Klintinghoved Formation based solely on the lithological succession, in the absence of a mollusc fauna.

\section{Arnum, Hodde, Gram and Sæd Formations}

In the comprehensive stratigraphic work by L.B. Rasmussen $(1958,1961,1966,1968)$, focus was on the upper Arnum Formation, and the Hodde and Gram Formations; the latter two formations were formally erected (L.B. Rasmussen 1961). He continued and extended Sorgenfrei's work, producing a biostratigraphic zonation of this stratigraphic interval. L.B. Rasmussen (1966) referred the Gram Formation (including the silt interval encountered in the borehole at Sæd) to the Upper Miocene and the Hodde Formation to the Middle Miocene (Fig. 5), assignments that have been largely confirmed by later work.

L.B. Rasmussen (1961; see also Laursen et al. 1998) suggested that sandy strata overlying the Gram Clay in south-west Jylland could be of Messinian (latest Miocene) age based on a mollusc fauna that was considered to be incompatible with the upper Gram Clay faunas; the Sæd Formation, overlying the Gram Formation, was thus proposed. Hinsch (1990) re-evaluated this mollusc fauna, however, demonstrating equivalence to the Tortonian fauna in the uppermost Gram Formation; this is supported by dinoflagellate floras in the same strata (Piasecki 2005). The Sæd Formation is therefore abandoned in the present paper.

\section{Odderup Formation (terrestrial Miocene)}

The Odderup Formation was erected by L.B. Rasmussen (1961) as the brown-coal and quartz-sand succession between the marine clays of the Arnum Formation and the overlying Hodde Formation. The observation of brown-coal or coal fragments and quartz sands below the marine Arnum Formation in certain wells, however, complicated the stratigraphic concept, but L.B. Rasmussen (1961) envisaged two major prograding deltaic units (Ribe and Odderup Formations) subdividing the marine Miocene into three major units (Klintinghoved Formation, Arnum Formation, Hodde-Gram Formations, see Fig. 5).

The geology of the Søby-Fasterholt area was published by Koch (1989) in a comprehensive resumé of palaeo- 
botanical, sedimentological and stratigraphic studies, including an analysis of the brown-coal seams. In this area, the Odderup Formation is bounded by marine strata of the Arnum Formation beneath and the overlying marine succession of the Hodde and Gram Formations. That part of the Odderup Formation containing brown coals was defined as the Fasterholt Member.

\section{Sequence stratigraphy and onshore-offshore correlation}

In a study of the Cenozoic of the Danish North Sea, Michelsen (1994; Michelsen et al. 1998) divided the late Palaeogene-Neogene succession into 3 allostratigraphic units: Units 5 to 7 . The succession was further subdivided into 11 depositional sequences. The unconformities recognised in the offshore geophysical data were not directly correlated onshore using seismic data, but were correlated to the onshore lithostratigraphic units based on the biostratigraphic data available at that time. The Danish offshore stratigraphy was integrated with the UK and Norwegian stratigraphy: Units 5 and 6 were correlated with the upper Hordaland Group (Lark Formation of Schiøler et al. 2007) whilst Unit 7 was correlated with the Nordland Group.

Sequence stratigraphy was applied to the onshore Miocene succession in southernmost Jylland based on the analysis of petrophysical logs from 6 wells combined with seismic data (E.S. Rasmussen 1996). The succession was divided into 6 depositional sequences ranging in age from the latest Oligocene to the latest Miocene. Precise dating of these sequences was precluded by a general lack of biostratigraphic data but the sequence stratigraphic framework was correlated with the existing lithostratigraphy. E.S. Rasmussen (2004b) introduced a new sequence stratigraphic subdivision, this time based on 16 new boreholes, outcrops and

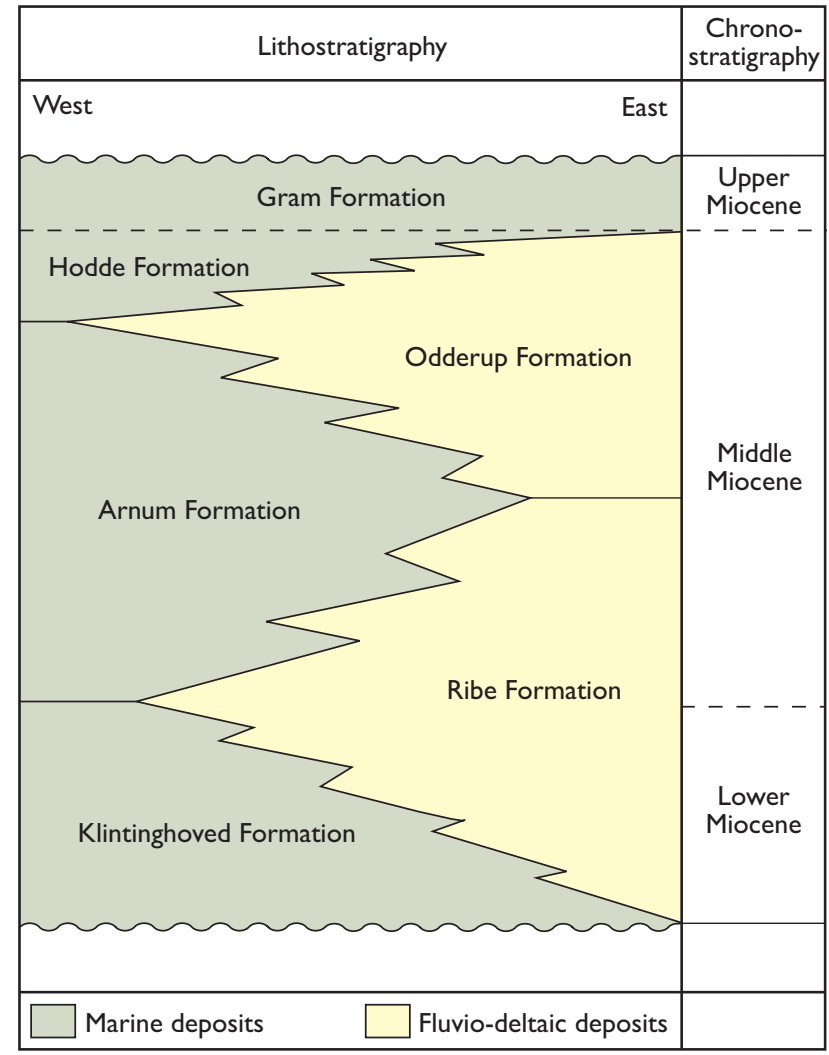

Fig. 5. Miocene lithostratigraphy of western Denmark as defined by L.B. Rasmussen (1961).

multichannel seismic data distributed in central and southern Jylland. This resulted in subdivision of the upper Oligocene - Miocene succession into 6 depositional sequences, a framework similar to that of E.S. Rasmussen (1996), although the ages of the sequences were refined on the basis of dinoflagellate cyst stratigraphy that was established over this period and formalised recently (Piasecki 1980, 2005; Dybkjær \& Rasmussen 2000, 2007; Dybkjær 2004a, b; Dybkjær \& Piasecki 2008, 2010). 


\section{Data and methodology}

Twenty-five outcrops, one cored borehole at Sdr. Vium (DGU no. 102.948) and c. 50 boreholes, drilled using the airlift drilling technique, were available for the study (Fig. 1). Most of the boreholes were drilled in order to solve stratigraphic problems, but some were drilled in order to test seismic facies interpretations. All boreholes are identified by their DGU borehole numbers, whereas outcrops are referred to by the nearest locality name.

All 25 outcrops and the cored borehole were described sedimentologically and samples taken for biostratigraphy.

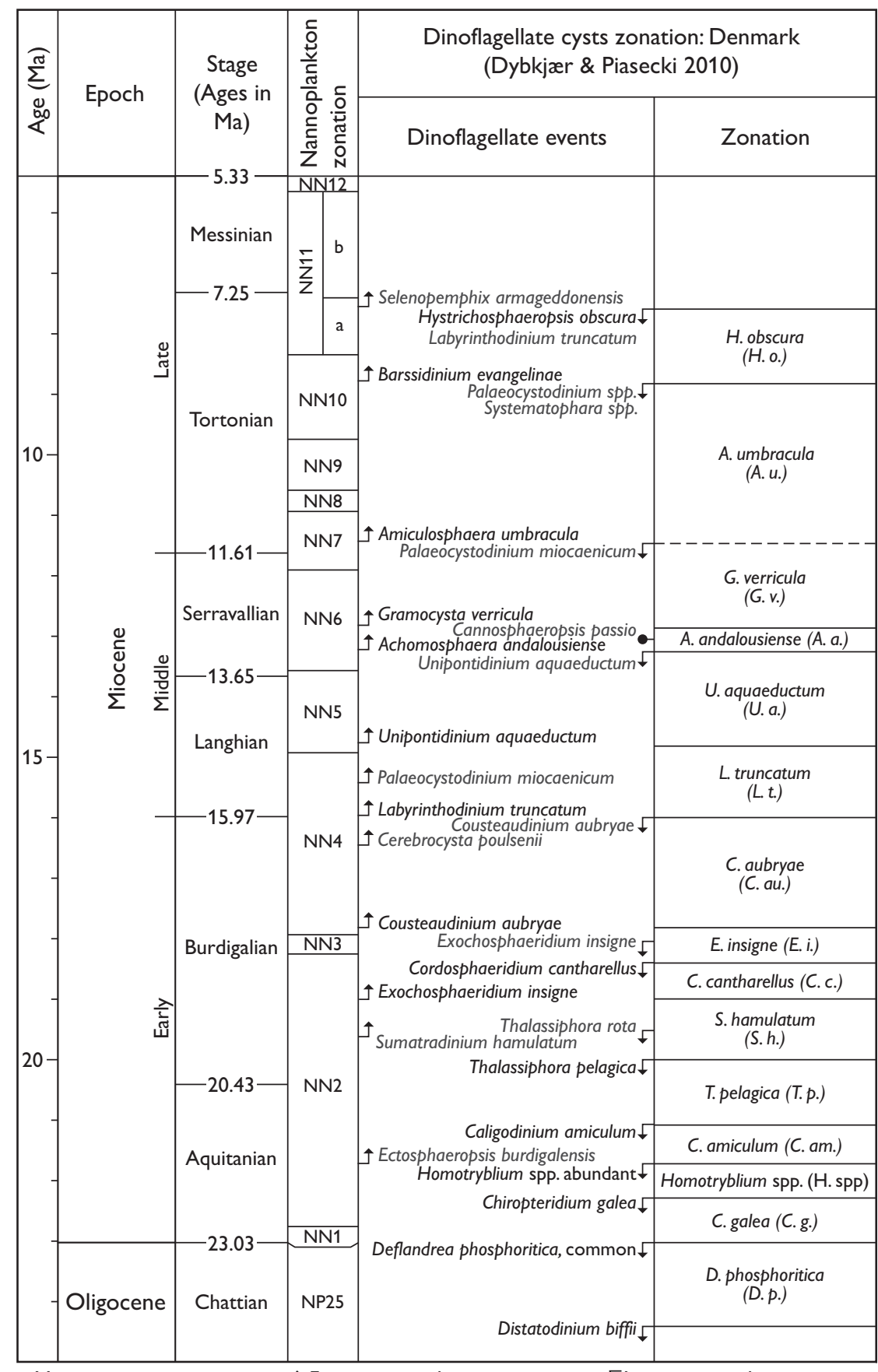

- Maximum occurrence $\uparrow$ First stratigraphic occurrence $\lceil$ Last stratigraphic occurrence
Fig. 6. Dinocyst zonation for the uppermost Oligocene - Miocene succession onshore Denmark, from Dybkjær \& Piasecki (2010). The ages of the stage boundaries are from Gradstein et al. (2004), the nannoplankton zonation from Martini (1971). NN: Neogene nannoplankton zone. NP: Palaeogene nannoplankton zone. Dinoflagellate events indicated in black define zone boundaries, those indicated in grey are additional diagnostic events. 


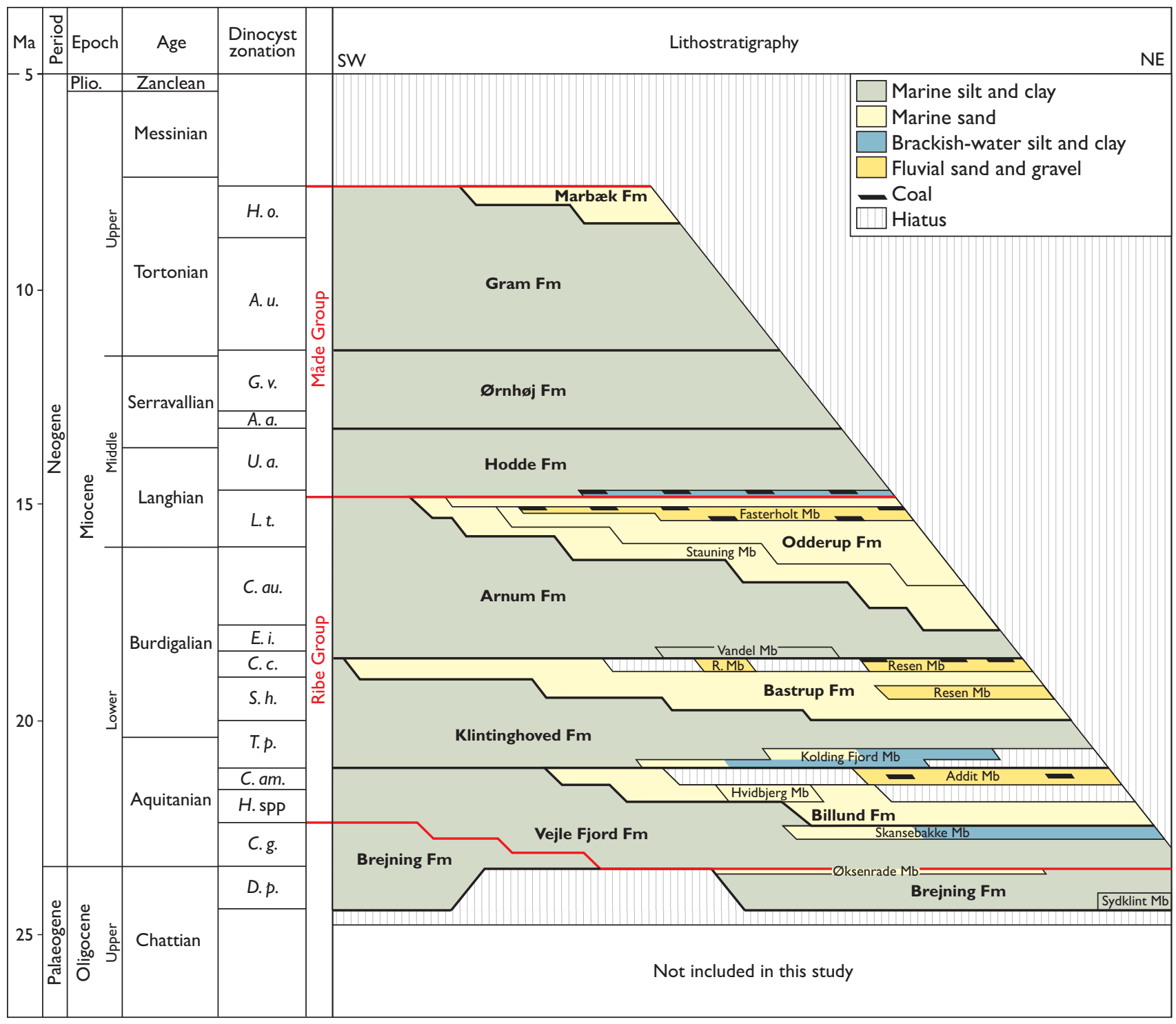

Fig. 7. Revised lithostratigraphic framework of the uppermost Oligocene - Miocene of onshore Denmark, as presented here. R.: Resen. Plio.: Pliocene.

The grain size and mineralogy of the airlift borehole samples, each representing one metre, were described. In addition, c. 40 samples per borehole were taken for biostratigraphic (dinocyst) analysis. The description of the Fasterholt Member, including the sedimentary logs, is based on Koch (1989).

In boreholes drilled using the airlift drilling technique, problems are experienced in retrieving fine-grained sand to the surface, and thus the recovery is commonly low or even zero in such intervals. As an aid to lithological identification, however, a gamma-ray log was obtained from all 50 boreholes. This petrophysical log is typically used to differentiate between sand and clay in siliciclastic sections, although sands rich in heavy minerals, glaucony and mica can give anomalous readings. In the correlation panels presented in this study (see Plates 1-9), the borehole lithologies were described by the first author, with the following exceptions: Fjand (DGU no. 76.635), Fjelstervang (DGU no. 84.2649), Lindved (DGU no. 116.1569), Løgumkloster (DGU no. 159.739), Ribe (DGU no. 140.42), Rømø (DGU no. 148.52), Tinglev (DGU no. 168.1378), Uldum (DGU no. 1444), Ulfborg (DGU no. 73.971), Vester Sottrup (DGU no. 169.799) and Vollerup (DGU no. 160.1378). Lithological descriptions of the latter boreholes are from the 'Jupiter' well database at the Geological Survey of Denmark and Greenland (GEUS). All sample depths from boreholes are adjusted using the gamma-ray log in order to get true depths of the samples. Thus there may be a dis- 
crepancy (usually less than $4 \mathrm{~m}$ ) between depths indicated in the Jupiter database (measured depth: MD) and the depths assigned to the lithostratigraphic units in this study. The measured depth of cuttings samples is, however, indicated in the text.

Approximately $1000 \mathrm{~km}$ of 2D high-resolution seismic data have been used to correlate between boreholes and to investigate the overall architecture of the Miocene succession. The correlations are also guided by dinocyst studies of most of the boreholes included here. These studies have resulted in a detailed dinocyst zonation (Fig. 6; Dybkjær \& Piasecki 2008, 2010). The geological age assigned to each lithostratigraphic unit is based primarily on this dinocyst stratigraphy (Fig. 7).

\section{Revised lithostratigraphy}

The lithostratigraphy of the uppermost Oligocene - Miocene succession of onshore Denmark is herein formally revised according to the guidelines presented by Salvador (1994). Nine lithostratigraphic units are revised and/or elevated in rank, 13 new lithostratigraphic units are erected.

The Oligocene to lowermost Miocene Brejning Clay Member, previously referred to the Vejle Fjord Formation, is elevated to formation status; it includes the Sydklint Member and the Øksenrade Member. The Miocene succession is subdivided into two groups, the Ribe and Måde Groups. The Ribe Group consists of the Vejle Fjord, Billund, Klintinghoved, Bastrup, Arnum, and Odderup Formations. The Vejle Fjord Formation includes the Skansebakke Member, the Billund Formation includes the Hvidbjerg and Addit Members, the Klintinghoved Formation includes the Kolding Fjord Member, the Bastrup Formation includes the Resen Member, the Arnum Formation includes the Vandel Member and the Odderup Formation includes the Stauning and Fasterholt Members. The Måde Group comprises the Hodde, Ørnhøj, Gram, and Marbæk Formations (Fig. 7). It should be noted that particularly distinctive portions of individual formations are defined as members, but the formations are not subdivided at member level in their entirety.

Lithostratigraphic definition of units in complex interdigitating lithologies requires clear recognition of the lithological (or petrophysical in subsurface data) bounding criteria for formations and members. In this study, the following criteria were adopted. The sand-rich formations (e.g. Billund, Bastrup, Odderup Formations) possess over $75 \%$ sand and have a minimum thickness of $5 \mathrm{~m}$; intercalated mudstone packets over $5 \mathrm{~m}$ thick are referred to the coeval marine, mud-rich formation (i.e. the Vejle Fjord Formation in the case of the sand-rich Billund Formation). Similarly, the marine, mud-dominated formations may contain subordinate sands; sand-rich intervals (with over
$75 \%$ sand) that exceed $5 \mathrm{~m}$ in thickness are referred to the coeval sand formation.

Salvador (1994) and subsequent lithostratigraphic guidelines (NACSN 2005) discourage the use of stratigraphically alternating formations in interdigitating depositional systems; the practical disadvantages in outcropping terranes are clear. In subsurface lithostratigraphy, however, this practise is adopted on occasion (e.g. Johnson \& Lott 1993) and is utilised here to emphasise the genetic integrity of the deltaic sandy systems.

\section{Brejning Formation}

new formation

History. The Brejning Formation corresponds to the Brejning Clay Member of the Vejle Fjord Formation of Larsen \& Dinesen (1959).

Name. After the town of Brejning, south of Vejle Fjord (Fig. 1).

Type and reference sections. The exposure at Skansebakke, Brejning (5540'19.74' $\left.\mathrm{N}, 9^{\circ} 41^{\prime} 33.84^{\prime \prime} \mathrm{E}\right)$ forms the type section for the Brejning Formation (Larsen \& Dinesen 1959, fig. 12). At low tide, the Brejning Formation is exposed in the basal, south-eastern part of the Skansebakke profile at Brejning. A borehole at Brejning encountered a c. $4 \mathrm{~m}$ thick $(-0.4$ to $-4.65 \mathrm{~m})$ section referred to the Brejning Formation (Larsen \& Dinesen 1959). The reference section is the outcrop at Dykær, Juelsminde (Fig. 8). Other exposures of the formation are found at Sanatoriet and Fakkegrav in the Vejle Fjord area, and at Jensgård at the mouth of Horsens Fjord. In central Jylland, the formation crops out at the Sofienlund clay pit; in the Lim- 


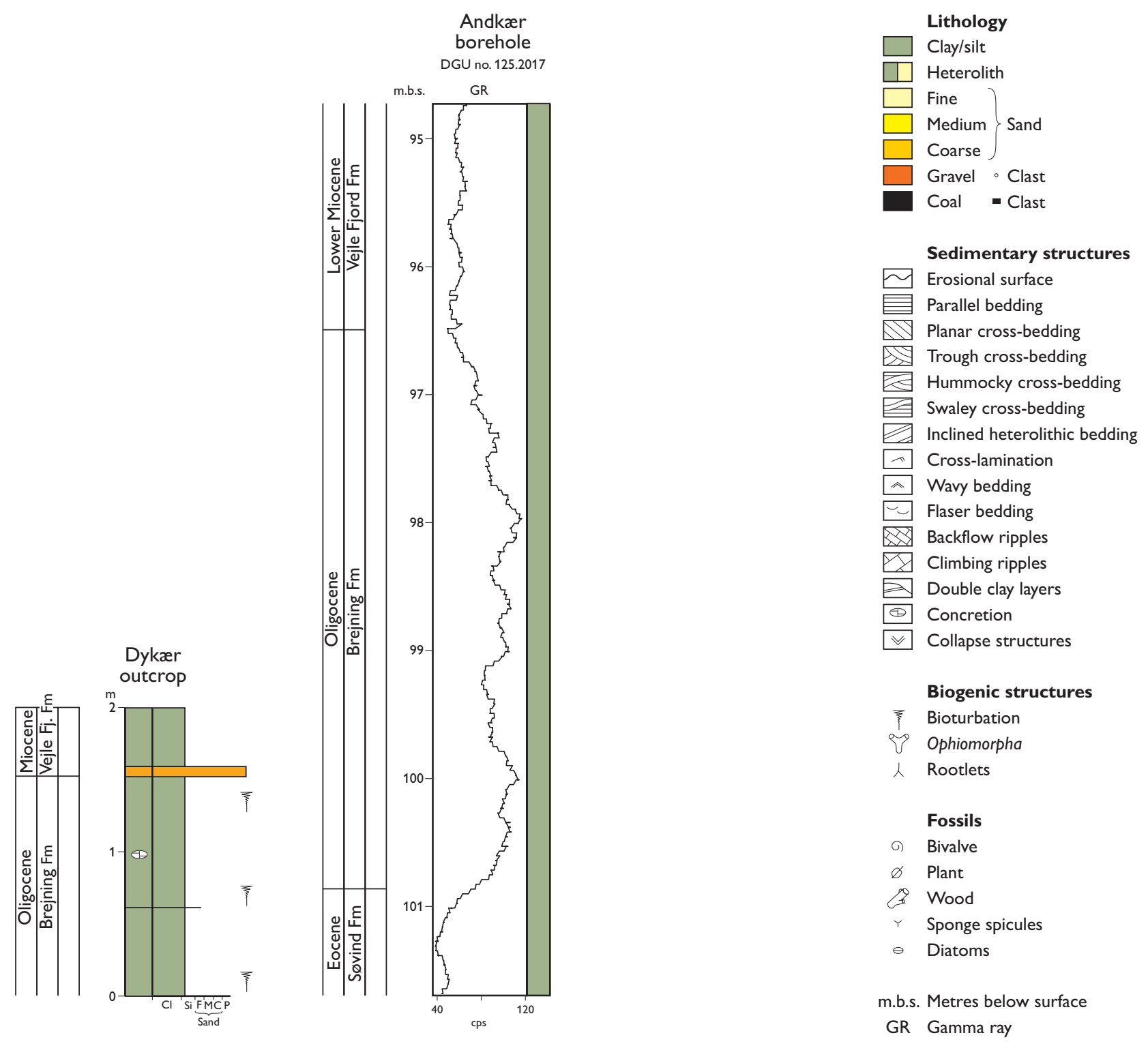

Fig. 8. Reference sections for the Brejning Formation. The primary reference section is the Dykær outcrop located south-west of Juelsminde and the secondary reference section is the interval from 100.9 to $96.5 \mathrm{~m}$ in the Andkær borehole. The accompanying legend is applicable to all outcrop and borehole logs shown in this study. Vejle Fj.: Vejle Fjord.

fjorden area, the formation is exposed at Lyby and Mogenstrup. Periodically, the formation is exposed at Søvind, Sønder Vissing, and in the Ølst and Hinge clay pits. The reference borehole section is the interval from 100.90 to $96.50 \mathrm{~m}$ (101-97 m MD) in the Andkær borehole (DGU no. 125.2017; Fig. 8).

Thickness. The Brejning Formation is normally $2-4 \mathrm{~m}$ thick, but is over $20 \mathrm{~m}$ thick in a number of wells (Plates 2, 5), and a $50 \mathrm{~m}$ thick succession referred to the Brejning Formation was encountered in the Borg-1 borehole (Plate 9).
Lithology. The Brejning Formation consists of greenish to brown, glaucony-rich clay with scattered pebbles (Fig. 9). In the upper part, there is an increased content of organic matter, silt and sand. Siderite concretions are also common in the upper part of the formation. The clay mineralogy is dominated by illite, but smectite, kaolinite and gibbsite are also present (Friis 1994; E.S. Rasmussen 1995). Mica is common in the upper part of the formation.

Log characteristics. High gamma-ray readings characterise the Brejning Formation (Fig. 8); the lower part, in particular, may show extremely high gamma-ray values due to 


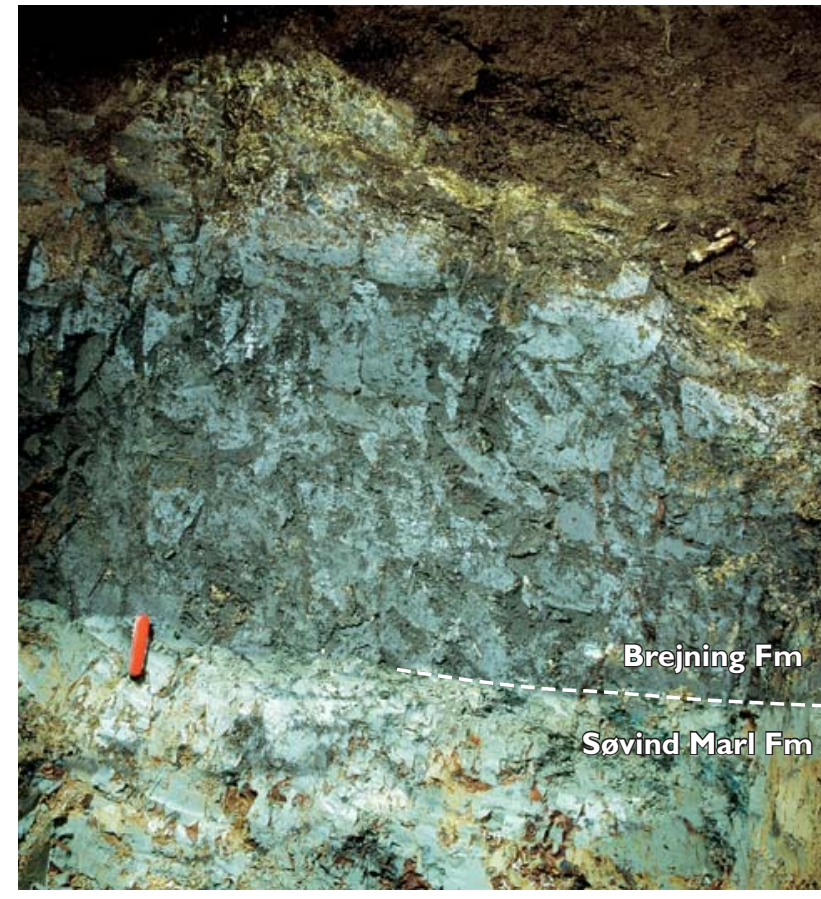

Fig. 9. The Brejning Formation at Øksenrade showing the lower part of the formation and the lower boundary with the underlying, light greenish-grey Middle Eocene Søvind Marl Formation (photograph courtesy of Peter Warna-Moors). Red penknife for scale, c. 10 cm long.

the high content of glaucony (e.g. Rødding borehole, Plate 8), although expanded sections (e.g. Borg borehole, Plate 9) may show uniform intermediate values.

Fossils. The marine clay of the Brejning Formation contains a rich mollusc fauna (Ravn 1907; Eriksen 1937; Schnetler \& Beyer 1987, 1990). Marine microfossils, such as foraminifers (Larsen \& Dinesen 1959; Ulleberg 1987, 1994; Laursen \& Kristoffersen 1999), calcareous nannofossils (von Salis Perch-Nielsen 1994) and dinocysts (Dybkjær 2004a, b; Rasmussen \& Dybkjær 2005), are represented, and foraminifers and dinocysts are abundant and diverse. In the upper part of the formation, a gradual change/detoriation in the mollusc fauna was interpreted to reflect a shallowing-upward trend. Similarly, in the Dykær and Jensgarrd exposures, the abundance and diversity of foraminifers (Larsen \& Dinesen 1959) and dinocysts decrease in the upper part of the formation whereas the abundance and diversity of spores, pollen and freshwater algae increase (Dybkjær 2004a, b; Rasmussen \& Dybkjær 2005). Echinoids, crinoids, asteroids, anthozoans, otoliths, sharks' teeth, brachiopods, crustaceans and bryozoans have also been found.
Depositional environment. The Brejning Formation was deposited in a fully marine, sediment-starved environment (Larsen \& Dinesen 1959; Schnetler \& Beyer 1990; E.S. Rasmussen 1995; Rasmussen \& Dybkjær 2005). The water depth was probably more than $200 \mathrm{~m}$ in the Norwegian-Danish Basin based on otoliths (Schnetler \& Beyer 1990) and benthic foraminifera (C. Morigi, personal communication 2009). The heights of clinoforms (offshore Denmark) associated with early Oligocene delta progradation indicate a minimum water depth of $200 \mathrm{~m}$ (Danielsen et al. 1997), and since the Late Oligocene was warmer than the Early Oligocene (Zachos et al. 2001), relatively deep water probably prevailed within the Norwegian-Danish Basin during deposition of the Brejning Formation. Schnetler \& Beyer (1990) reported a mixed mollusc fauna, some elements indicating deep marine conditions and some indicative of shallow water; the shallow marine fauna is most likely reworked, i.e. transported down the delta or shelf slope to the basin floor. On the Ringkøbing-Fyn High, shallower water prevailed. The upward increase in silt and sand indicates progradation of the shoreline in the latest Oligocene associated with a relative sea-level fall (Rasmussen \& Dybkjær 2005).

Boundaries. In southern and western Jylland, the Brejning Formation rests with a sharp and erosional boundary on the Eocene Søvind Marl Formation (Fig. 9; HeilmannClausen et al. 1985). In this area, the boundary is marked by a distinct change in colour and grain size from the greenish grey clay of the Søvind Marl Formation to the greenish brown and commonly silty Brejning Formation. The boundary may locally be intensively bioturbated and consequently more gradational. In central and northern Jylland, the boundary is defined where dark brown clay of the Branden Formation (lower Upper Oligocene) is overlain by greenish glaucony-rich clay of the Brejning Formation. The base of the Brejning Formation is marked by a prominent shift to higher values on the gamma-ray log in the Andkær borehole, but may locally be more gradational due to glaucony-filled burrows in the upper part of the Søvind Marl Formation.

The upper boundary is typically sharp and characterised by a change from greenish, dark brown, glaucony-rich clayey silt of the Brejning Formation to dark brown clayey silt of the overlying Vejle Fjord Formation. A change in the degree of consolidation is also observed at the boundary in most parts of Jylland from the well-consolidated sediments of the Brejning Formation to the relatively loose sediments of the Vejle Fjord Formation. A gravel layer commonly occurs immediately above the upper boundary. At the type locality, the upper boundary is recognised by a dis- 

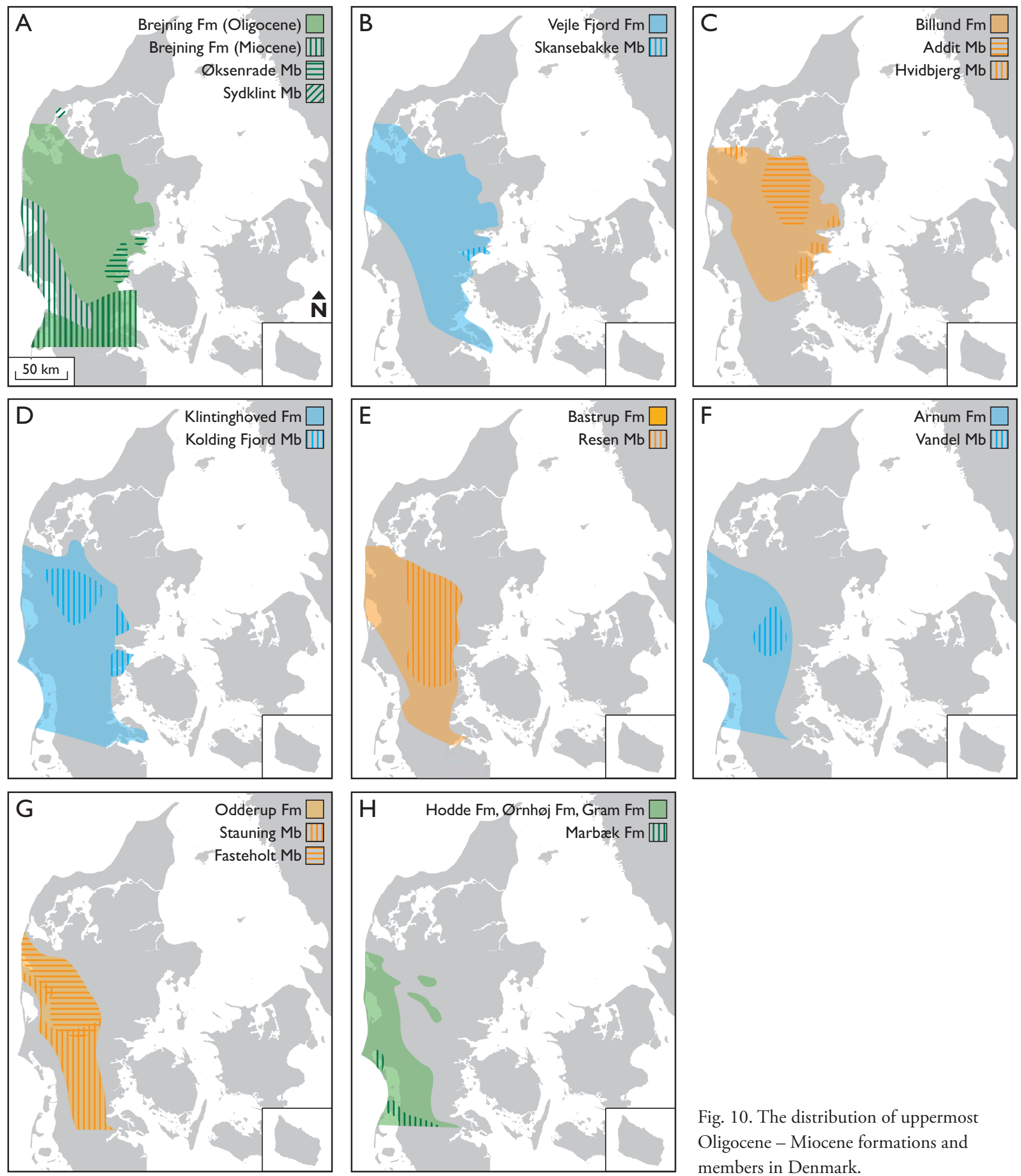

Fig. 10. The distribution of uppermost Oligocene - Miocene formations and members in Denmark.

tinct decrease in the content of glaucony passing from the Brejning Formation to the Vejle Fjord Formation (Larsen \& Dinesen 1959). The scattered glaucony grains found in the Vejle Fjord Formation are reworked (E.S. Rasmussen
1987). In central east Jylland, the boundary is commonly characterised by a marked change from the sand deposits of the Øksenrade Member to the dark brown, clayey silt of the Vejle Fjord Formation. 


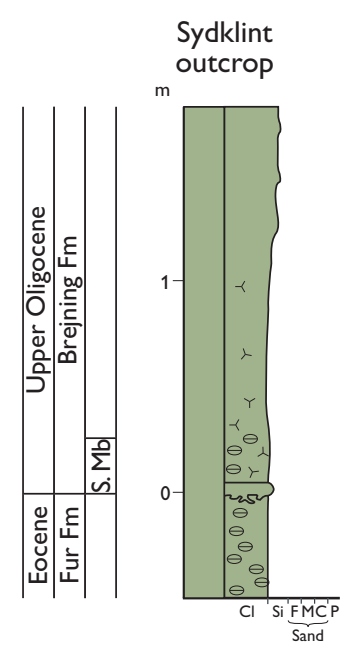

Fig. 11. Type section of the Sydklint Member. Modified after Heilmann-Clausen (1997); for legend, see Fig. 8, p. 17. S.: Sydklint.

Distribution. The Brejning Formation is present in much of central and southern Jylland but is typically absent on the Ringkøbing-Fyn High (Fig. 10A). Due to the diachronous nature of the upper boundary (see below), the youngest beds referred to the Brejning Formation are only present in southern and western Jylland. The northern and eastern limit closely follows that of the Miocene deposits (Fig. 3).

Biostratigraphy. The Deflandrea phosphoritica Dinocyst Zone of Dybkjær \& Piasecki (2010) is recorded in the Brejning Formation. In addition, the Chiropteridium galea Zone is recorded in the upper part of the formation in the southern parts of Jylland.

Geological age. The Brejning Formation is of late Chattian to early Aquitanian (latest Late Oligocene to earliest Early Miocene) age. The dinocyst stratigraphy indicates that the upper boundary of the Brejning Formation is diachroneous. In central parts of Jylland, the boundary broadly correlates with the Oligocene-Miocene boundary (E.S. Rasmussen 2004b; Rasmussen \& Dybkjær 2005; Dybkjær $\&$ Rasmussen 2007). In the southern part of Jylland, deposition of the glaucony-rich clay of the Brejning Formation apparently continued into the early Aquitanian.

Subdivision. The Brejning Formation includes the Sydklint Member and the new Øksenrade Member.

\section{Sydklint Member}

History. A thin diatomite layer of Oligocene age, unconformably overlying the Lower Eocene Fur Formation and

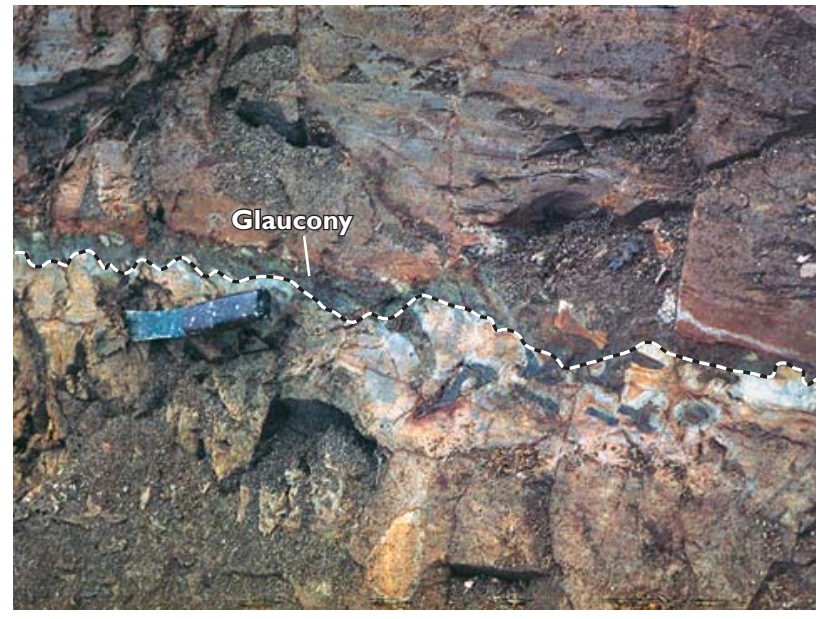

Fig. 12. Contact between the light grey Lower Eocene Fur Formation and the brown Upper Oligocene Sydklint Member at Silstrup Sydklint. A thin glauconitic layer occurs at the boundary between the two units. Thalassinoides burrows extend from the glauconitic layer down into the topmost Fur Formation. Knife for scale.

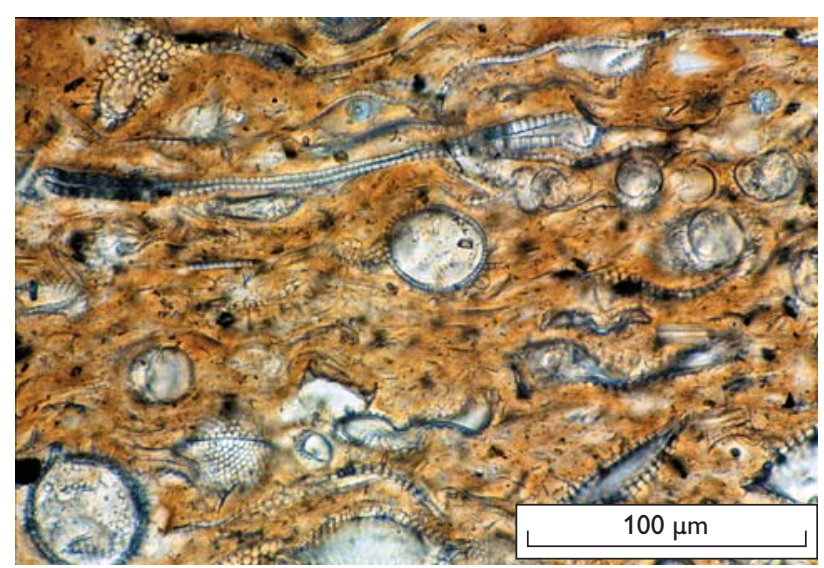

Fig. 13. Photomicrograph of a vertical thin-section through the diatomaceous Sydklint Member.

overlain by Upper Oligocene micaceous clay, was observed in the cliff section at Silstrup, near Thisted, by HeilmannClausen (1982). Although noted by Bøggild (1918), he apparently considered the layer to represent a glaciotectonically derived slice of the Fur Formation (see HeilmannClausen 1997). The silicoflagellate assemblage in the diatomite layer was described by von Salis (1993). The lithology of the Oligocene diatomite layer and the contact to the underlying Fur Formation were described in more detail by Heilmann-Clausen (1997) who also proposed a model for the genesis of the diatomite. Heilmann-Clausen (1997) formally defined the unit as the Sydklint Member, which he provisionally referred to the Vejle Fjord Formation. 
Name. After the coastal cliff of Silstrup Sydklint, south of Thisted (Fig. 1).

Type section. The type section is the coastal cliff of Silstrup Sydklint (56 $55^{\prime} 15.49^{\prime \prime} \mathrm{N}, 8^{\circ} 39^{\prime} 20.76^{\prime \prime}$ E; Fig. 11).

Thickness. The member is up to $28 \mathrm{~cm}$ thick.

Lithology. The Sydklint Member includes a basal 1-8 cm thick clay layer rich in coarse-grained glaucony and reworked clasts of the Fur Formation (Figs 11, 12). Sporadic extrabasinal pebbles and a single $25 \mathrm{~cm}$ large, partly glauconitised gneiss clast have been found in the basal layer. The glaucony-rich basal layer is succeeded by $20 \mathrm{~cm}$ of brown, clayey diatomite (Fig. 13).

Log characteristics. The member is only recognised at outcrop, and log data are not available.

Fossils. The Sydklint Member contains well-preserved siliceous and organic-walled microfossils, including diatoms, silicoflagellates, sponge spicules, dinocysts, pollen and spores (Fig. 13).

Depositional environment. The Sydklint Member was deposited in a marine, probably shelf environment.

Boundaries. The Sydklint Member has a sharp lower boundary separating the glaucony-rich basal layer from the underlying Fur Formation. An omission suite of shallow Thalassinoides burrows extends 5-8 cm down into the topmost Fur Formation. The upper boundary is gradational over a few centimetres.

Distribution. The Sydklint Member is only known from outcrops at Silstrup Sydklint and nearby Klovbakker at Sundby, Mors.

Biostratigraphy. The member is referred to the silicoflagellate Distephanus speculum haliomma Subzone of Bukry (1981) by von Salis (1993) and to the Deflandrea phosphoritica Dinocyst Zone of Dybkjær \& Piasecki (2010) by Heilmann-Clausen (C. Heilmann-Clausen, personal communication 2010).

Geological age. The Sydklint Member is of late Chattian (latest Late Oligocene) age.

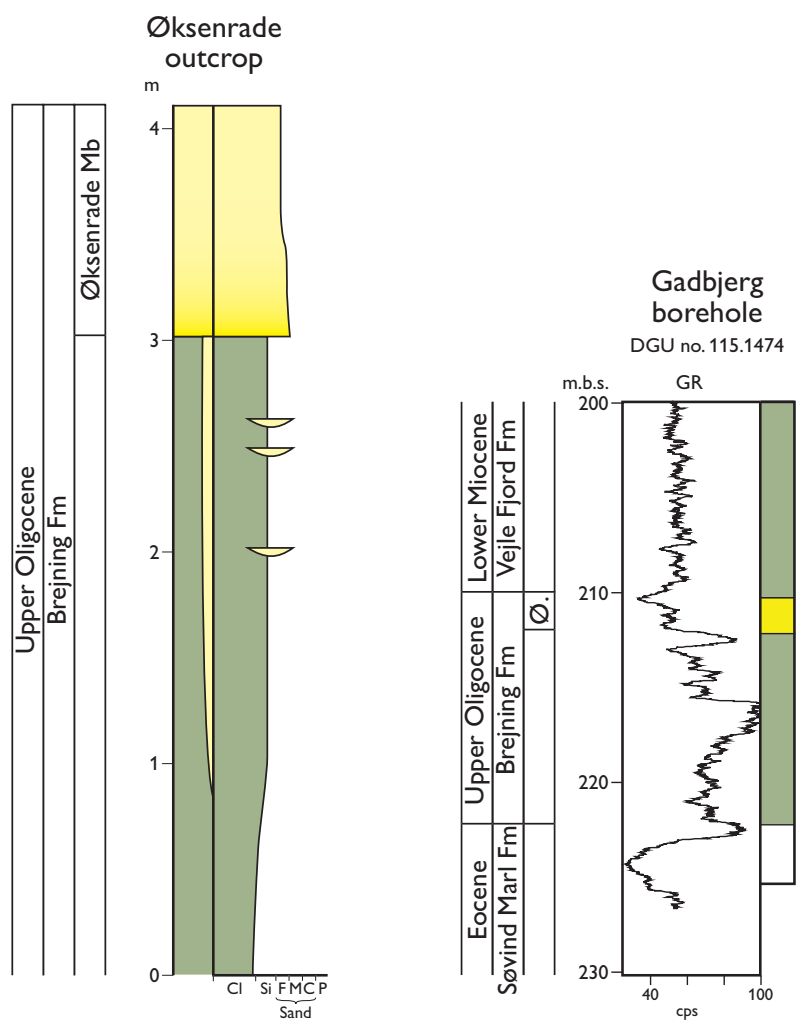

Fig. 14. Type and reference sections of the Øksenrade Member (Ø.). The type section is the Øksenrade outcrop located south-west of Middelfart; the top of the member is not seen. The reference section is the interval from 212 to $210 \mathrm{~m}$ in the Gadbjerg borehole; for legend, see Fig. 8, p. 17.

\section{$\varnothing$ ksenrade Member}

new member

History. The succession defined here as the Øksenrade Member was termed 'Middelfart malm' by L.B. Rasmussen (1975). Equivalent oolitic ironstones cropping out at Jensgård at the mouth of Horsens Fjord were described by Friis et al. (1998).

Name. After Øksenrade Skov, just north of the coastal type locality (Fig. 1).

Type and reference sections. The type section is the coastal cliff facing Fænø Sund, south of Øksenrade Skov, Middelfart $\left(55^{\circ} 29^{\prime} 39.61^{\prime \prime} \mathrm{N}, 9^{\circ} 42^{\prime} 47.29^{\prime \prime} \mathrm{E}\right.$; Fig. 14). The reference section is the interval from 212 to $210 \mathrm{~m}$ (214-212 $\mathrm{m} \mathrm{MD}$ ) in the borehole at Gadbjerg (Fig. 14; DGU no. 115.1474). 


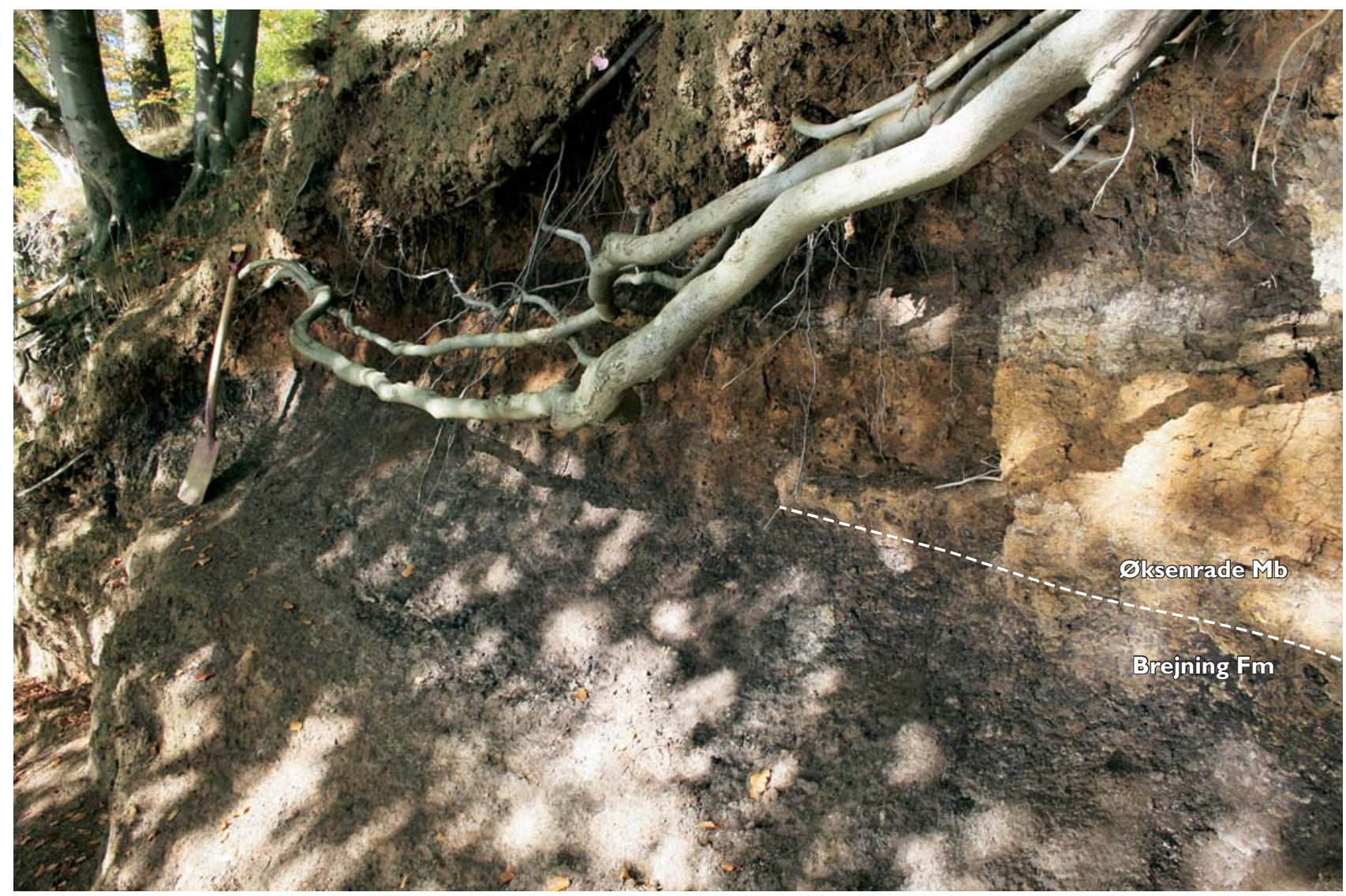

Fig. 15. Brejning Formation and the Øksenrade Member in the coastal cliff at Øksenrade Skov, south-west of Middelfart. This outcrop constitutes the type section of the Øksenrade Member; spade for scale (c. $1.3 \mathrm{~m}$ long).

Thickness. The member is $c .1 \mathrm{~m}$ thick at the type locality (Fig. 14), but the top is not seen; boreholes indicate a maximum thickness of $5 \mathrm{~m}$ (Fig. 14; Plate 8).

Lithology. The Øksenrade Member is composed of reddish ooids and grey, well-sorted, fine-grained quartz sand (Figs $15,16)$ and ranges lithologically from a sand with dispersed ooids to a sandy ooid grainstone. At Jensgarrd, the Øksenrade Member consists of planar cross-bedded sand, sets are up to $40 \mathrm{~cm}$ thick and typically show asymptotic toesets. The foresets are inclined towards the north. The ooids are composed of concentric layers of goethite, commonly with a core of glaucony grains or pellets (H. Friis, personal communication 2010); at the type section, shells or quartz grains also form ooid cores. The cement consists of siderite with some calcite; the iron content of the sediment is up to 30\% (E.S. Rasmussen 1987). Moulds of mollusc shells are common.

Log characteristics. The Øksenrade Member is typified by relatively low gamma-ray readings (Fig. 14) but distinct spikes may occur due to horizons rich in glaucony.
Fossils. The Øksenrade Member is characterised by abundant moulds of mollusc shells (L.B. Rasmussen 1975; Gravesen 1990).

Depositional environment. The Øksenrade Member was deposited above storm wave base as indicated by cross-bedding (Rasmussen \& Dybkjær 2005). The bivalve and gastropod faunas (L.B. Rasmussen 1975) also indicate a shallow-water depositional environment. The transgressive lag that is locally found on the Ringkøbing-Fyn High at the base of the Vejle Fjord Formation is indicative of exposure and terrestrial sedimentation prior to transgressive reworking (Rasmussen \& Dybkjær 2005). Such a shallowing and local emergence at the transition from the Oligocene to the Miocene is also indicated by the presence of freshwater algae in the upper part of the Brejning Formation (Rasmussen \& Dybkjær 2005).

Boundaries. The Øksenrade Member rests with a sharp erosional boundary on the undifferentiated Brejning Formation beneath (Figs 15, 16). The lower boundary is also marked by a change from dark brown, clayey silt with scat- 


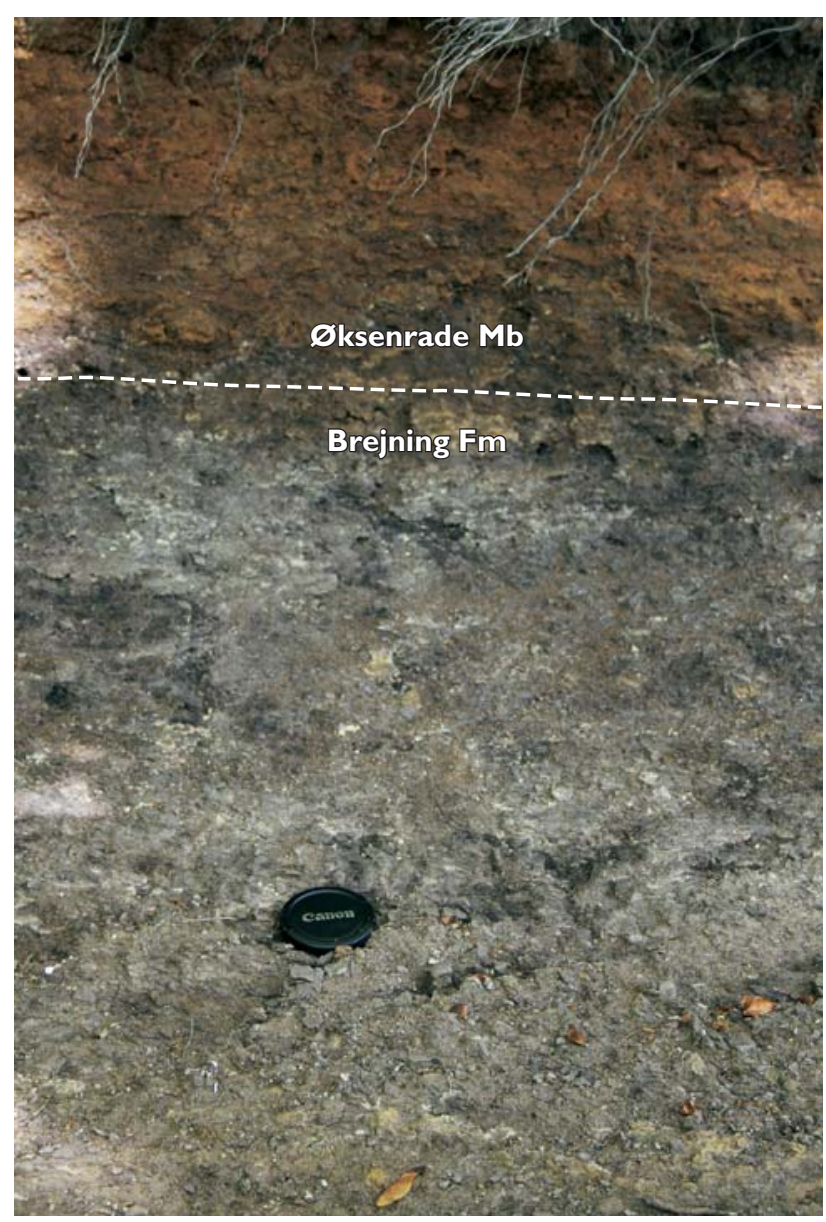

Fig. 16. Boundary between the Brejning Formation and the Øksenrade Member, marked by a distinct colour change from dark brown clayey silt to red sand. Lens cap for scale. tered sand lenses to fine-grained, reddish sand; on the gamma-ray log, this facies shift is reflected by a shift towards lower values. The upper boundary is characterised by a marked change from the sand deposits of the Øksenrade Member to dark brown, clayey silts of the Vejle Fjord Formation; this boundary is marked by a prominent shift on the gamma-ray log from low to high values.

Distribution. The Øksenrade Member is present in east Jylland and the extreme western part of Fyn, from Horsens in the north to Middelfart in the south (Fig. 10A). The westernmost limit is defined by exposures at Gadbjerg near Give where the member occurs on a footwall crest at the boundary fault of the Brande Trough.

Biostratigraphy. No samples from this member have been analysed for palynology; the mollusc fauna is non-specific.

Geological age. Based on stratigraphic context, the Øksenrade Member is considered of latest Chattian (latest Late Oligocene) age. 
Ribe Group

new group

History. Non-fossiliferous sand and gravel encountered below $125.6 \mathrm{~m}$ in a borehole at Ribe were defined as the Ribe Formation by Sorgenfrei (1958). The borehole terminated at a depth of $127 \mathrm{~m}$ and thus the base of the formation was never defined. L.B. Rasmussen (1961) suggested that a succession of quartz gravel and sand with some lignite between 255.7 and $144.5 \mathrm{~m}$ in the Arnum-1 borehole should be referred to the Ribe Formation. He further indicated that the fluvio-deltaic, brown-coal-bearing succession around Silkeborg and Skanderborg may be correlative with the Ribe Formation. In this stratigraphic revision, however, the fluvio-deltaic deposits at Silkeborg are referred to the Vejle Fjord and Billund Formations.

The Ribe Formation was included in the stratigraphic chart of L.B. Rasmussen (1961) where it was suggested to encompass the fluvio-deltaic deposits below the Odderup Formation. The age of the formation was indicated as Early to early Middle Miocene (Fig. 4).

During the last decade, detailed biostratigraphic and sequence stratigraphic studies of the Lower Miocene succession have been carried out (E.S. Rasmussen 2004b; Dybkjær 2004a; Rasmussen \& Dybkjær 2005; E.S. Rasmussen et al. 2006; Dybkjær \& Piasecki 2010). These studies have revealed that the stratigraphy of the Lower Miocene deposits is more complicated than formerly believed. The fluvio-deltaic sediments that are so characteristic of the Lower Miocene - lower Middle Miocene succession are thus here defined as the Ribe Group. The introduction of the Bastrup Formation, which replaces the Ribe Formation in southern Jylland, is also consistent with the new lithostratigraphy of Schleswig-Holstein, northern Germany (Rasser et al. 2008; Knox et al. 2010). Here the Bastrup Formation was adopted to represent Lower Miocene fluvio-deltaic sands of Burdigalian age, based on a study of the Kasseburg cored borehole near Hamburg (K. Gürs, personal communication 2006; Rasser et al. 2008; Knox et al. 2010).

The Ribe Group correlates with the upper part of the Hordaland Group as applied in the North Sea region,

Fig. 17. The full development of the Ribe Group is illustrated by the interval from 219 to $1 \mathrm{~m}$ in the Store Vorslunde borehole, north-east of Vejle; for legend, see Fig. 8, p. 17. Br.: Brande. Oligo.: Oligocene.

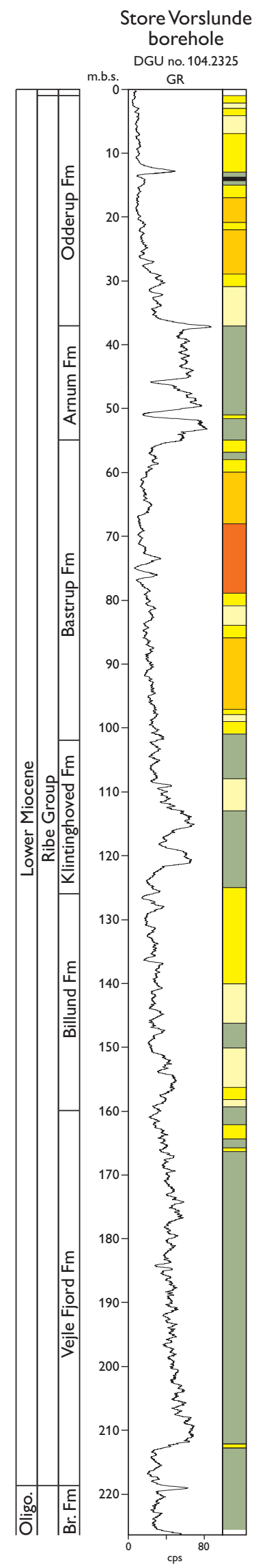



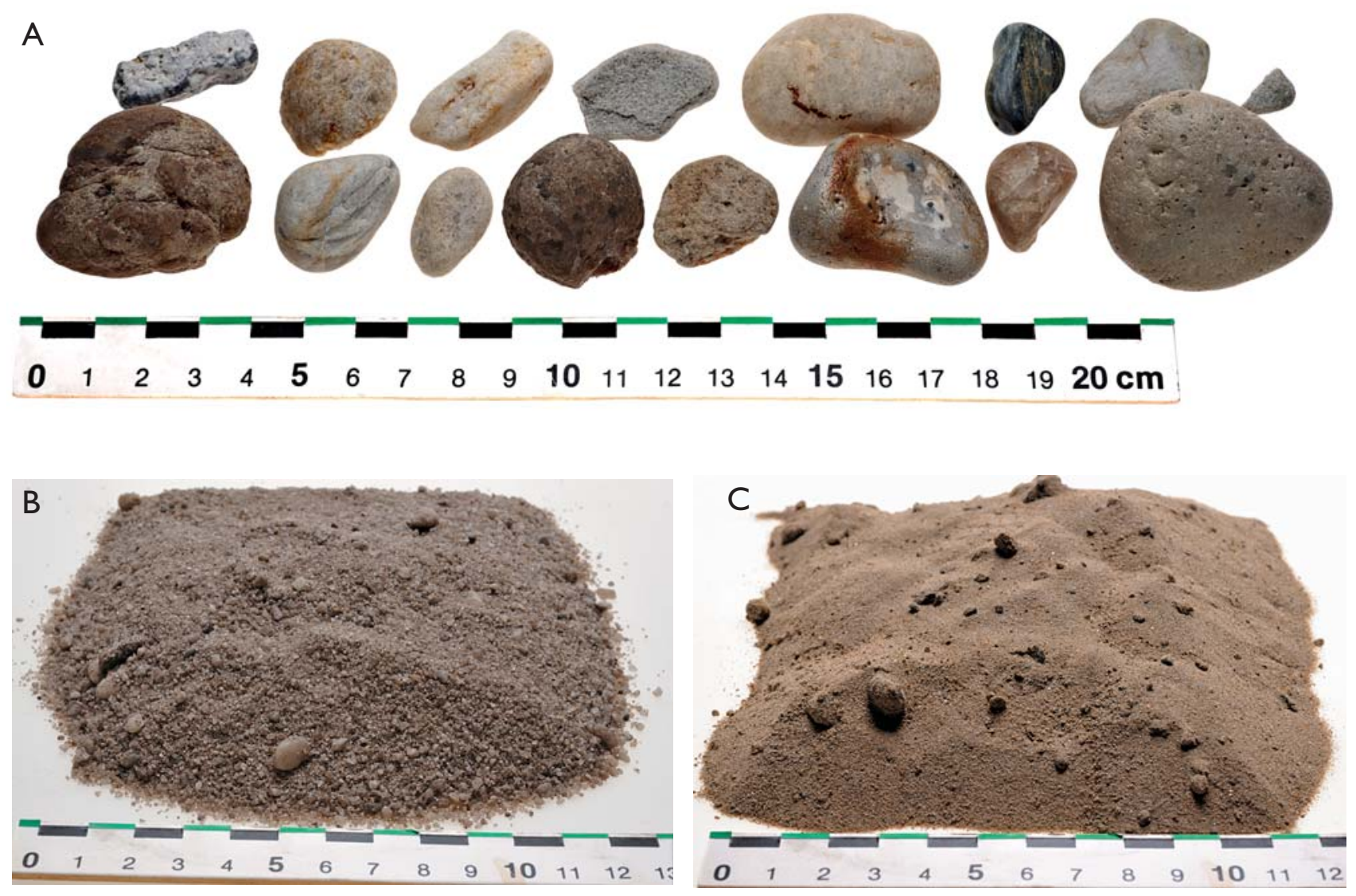

Fig. 18. Quartz-rich sand and pebbles from the Miocene fluvio-deltaic deposits; photographs courtesy of P. Warna-Moors. A: Pebbles of quartz, quartzite and chert; these are commonly found near sequence boundaries, associated with transgressive lags or within fluvial channels. Note that the clasts are up to $3 \mathrm{~cm}$ in diameter. B: Granules and coarse-grained sand of the Billund Formation. C: Fine- and medium-grained sand of the Billund Formation.

including offshore Denmark in the Norwegian-Danish Basin (Deegan \& Scull 1977; Hardt et al. 1989; Schiøler et al. 2007).

Name. After the town of Ribe (Fig. 1).

Type area. The type area of the Ribe Group is central and east Jylland. In the gravel pit at Voervadsbro in central Jylland (Fig. 1), both marine sand and fluvial sand and gravel of the Ribe Group are exposed. In the Store Vorslunde borehole (Fig. 17; DGU no. 104.2325) a complete section through the group is represented in the interval from 219 to $1 \mathrm{~m}$ (220-1 m MD). The group crops out at Klintinghoved in southern Jylland, at Rønshoved, Hagenør, Børup, Hindsgavl, Galsklint, Hvidbjerg, Brejning, Sanatoriet, Fakkegrav, Dykær and Jensgård in eastern Jylland, at Addit, Salten, Isenvad and Abildå in central Jylland and at Gyldendal, Søndbjerg, Lyby, Skyum Bjerge, Skanderup and Lodbjerg in the Limfjorden area.
Thickness. The group is $218 \mathrm{~m}$ thick in the Store Vorslunde borehole. A thickness of $c .200 \mathrm{~m}$ is common in the Norwegian-Danish Basin and in most places on the Ringkøbing-Fyn High. In the Tinglev borehole, located in the Tønder Graben, more than $200 \mathrm{~m}$ has been penetrated without reaching the lower boundary of the group (Plate 1). Reduced thicknesses are seen in the eastern part of Jylland, partly due to erosion during the Pleistocene.

Lithology. The group consists of three cycles of alternating mud-rich and sand-rich units with some intercalation of coal beds, especially in the upper cycle (Odderup Formation); each cycle, 50 to $100 \mathrm{~m}$ thick, represents a coarsening-upward cycle. The sands are typically medium- to coarse-grained, quartz-rich with a variable mica content. Various types of cross-bedding, including tabular, trough, hummocky and swaley cross-stratification, characterise the sand-rich units. The sand grains are normally sub- to wellrounded. Well-rounded pebbles of quartz, quartzite and 


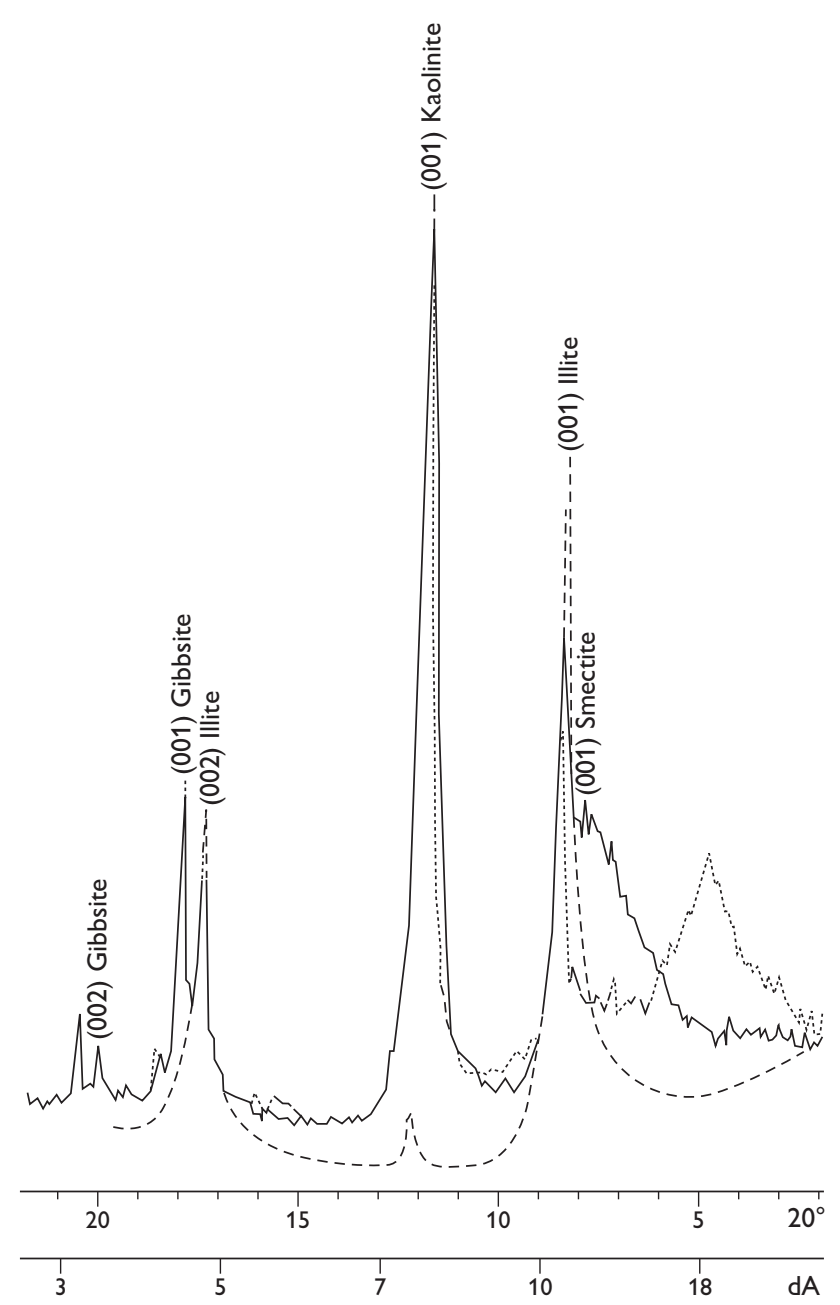

Fig. 19. X-ray diffractogram of the clay fraction from muds of the Vejle Fjord Formation (Ribe Group). Note that gibbsite is present indicating that the source area was heavily weathered. Full line = untreated samples, dotted line $=$ glycolated samples and dashed line = samples heated to $500^{\circ} \mathrm{C}$. Modified from E.S. Rasmussen (1995). dA: lattice separation (in angstrom).

chert up to $4 \mathrm{~cm}$ in size (Fig. 18) commonly occur in the upper part of the units near sequence boundaries (in transgressive lags or fluvial channels). Fossils occur only sporadically in the sand-rich units.

The micaceous, mud-rich portions of the group are typically homogeneous, with some intercalation of laminated mud intervals as well as discrete sand layers. The sand layers are commonly hummocky cross-stratified or represent tidal rhythmites. The clay mineral association is dominated by illite, kaolinite and gibbsite (Fig. 19); pyrite is a very common authigenic mineral.

The coal beds are found associated with cross-stratified fluvial sands and muds, and also cap shoreface/beach sands and lagoonal muds. The coal beds are limited to the
Norwegian-Danish Basin where they typically reach thicknesses of 2-3 m; the thickest succession has been recorded in the Fasterholt area, where there is a cumulative thickness of about $9 \mathrm{~m}$ of coal. Lithological details of the respective formations of the Ribe Group are given below under the individual formation descriptions.

Log characteristics. The typical log pattern shows three cycles of decreasing-upward gamma-ray values (Fig. 17). The gamma-ray log is generally characterised by a serrated pattern, but distinct gamma-ray spikes are common in the lower part of each cycle; in the upper cycle (the Arnum and Odderup Formations), high gamma-ray spikes occur throughout the succession. In the northern part and also locally in the southern part, decreasing gamma-ray values are commonly observed in the upper part of each cycle. For more detailed descriptions, see the individual units below.

Fossils. Molluscs occur abundantly in the marine and nearshore deposits and plant fossils are locally abundant in the terrestrial deposits. More detailed descriptions of the fauna/flora are given below in the definitions of the formations and members.

Depositional environment. The Ribe Group was deposited by delta systems prograding from the north and north-east towards the south and south-west. Deposition of the first cycle (Billund Formation) was strongly controlled by the topography formed during Early Miocene inversion tectonism (Rasmussen \& Dybkjær 2005; Hansen \& Rasmussen 2008; E.S. Rasmussen 2009a). During the deposition of this cycle, the so-called Ringkøbing and Brande lobes were focussed particularly within structural lows, the Brande Trough and the Rødding Graben (Hansen \& Rasmussen 2008). East of the main delta lobes, spit and barrier-complexes developed due to shore-parallel transport of sand that was delivered from the river mouths of the delta systems (Rasmussen \& Dybkjær 2005; Hansen \& Rasmusen 2008). Fluvial sands interpreted as braided river system deposits (Hansen 1985; Jesse 1995; E.S. Rasmussen et al. 2006) dominate in the northern part.

The second cycle (Bastrup Formation) shows a more evenly distributed progradational pattern across Jylland. Due to the lack of outcrops of this part of the Miocene succession, detailed sedimentology has not been carried out. Judging from borehole data, there are no indications of widespread spit and barrier complexes. As for the first cycle, fluvial systems dominate the upper part of the succession. Log and seismic data (E.S. Rasmussen et al. 2007; E.S. Rasmussen 2009b) indicate that a meandering fluvial sys- 
tem was widespread, although local or periodic development of braided fluvial systems may have taken place.

The third and final cycle (the Odderup Formation) was deposited in a prograding coastal plain with widespread coal formation within the Norwegian-Danish Basin, whereas clean fluvial sand dominates the Ringkøbing-Fyn High area.

Boundaries. The lower boundary is commonly sharp, being defined where greenish to brownish, glaucony-rich clay and silt is overlain by dark brown, organic-rich mud. Over much of Jylland, the boundary is also marked by a change in the degree of consolidation, from the well-consolidated sediments of the Oligocene Brejning and Branden Formations to poorly consolidated Ribe Group sediments. The boundary may be marked by a gravel lag or sand bed. Due to intense bioturbation, the boundary may be locally blurred. In central east Jylland, the boundary is characterised by a marked change from the sand deposits of the Øksenrade Member to dark brown clayey silt of the Vejle Fjord Formation of the Ribe Group. The upper boundary is sharp, being marked by a thin gravel layer that separates the white, fine-grained sand of the uppermost Ribe Group (Odderup Formation) from the dark brown mud of the succeeding Måde Group. This is reflected by a prominent shift on the gamma-ray log towards high gamma-ray values.

Distribution. The Ribe Group is present over most of Jylland. The northern and eastern limits of the group closely follow the lower boundary of the Miocene deposits (Fig. 4)

Geological age. The Ribe Group is of Aquitanian - early Langhian (Early Miocene - earliest Middle Miocene) age.

Subdivision. The Ribe Group is divided into six formations: the Aquitanian Vejle Fjord and Billund Formations, the uppermost Aquitanian - lower Burdigalian Klintinghoved and Bastrup Formations and the upper Burdigalian - lower Langhian Arnum and Odderup Formations (Fig. 7).

\section{Vejle Fjord Formation}

redefined formation

General. The marine, clay-dominated Vejle Fjord Formation interdigitates north-eastwards with the fluvio-deltaic, sandrich Billund Formation. These two formations thus alternate up-section in some boreholes (e.g. Plates 2-8).

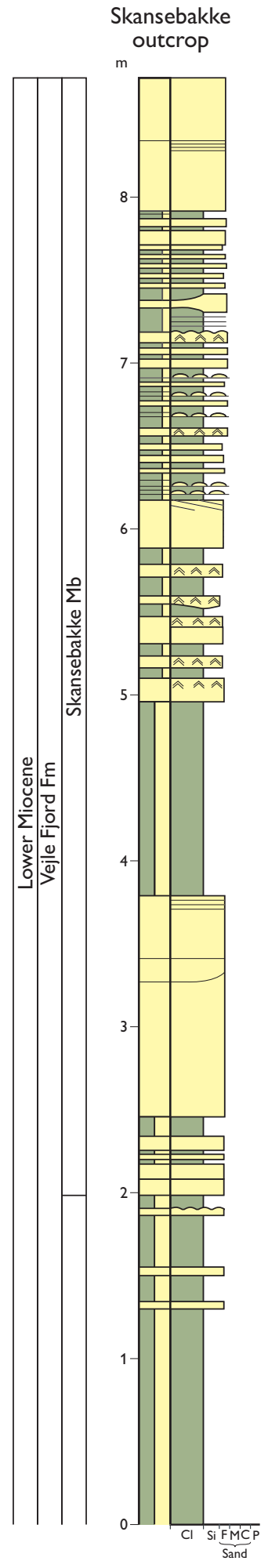

Fig. 20. Type section of the Vejle Fjord Formation and the Skansebakke Member at Skansebakke, Brejning; for legend, see Fig. 8, p. 17. 


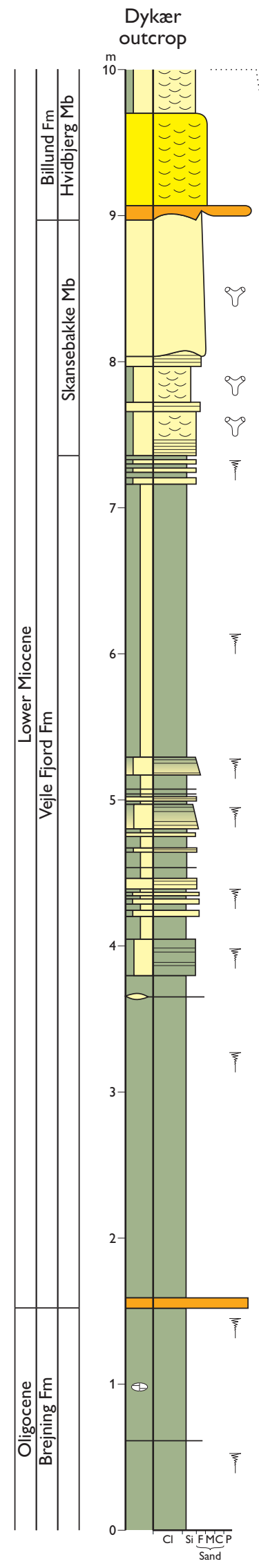

Fig. 21. Primary reference section of the Vejle Fjord Formation at Dykær, south-west of Juelsminde; for legend, see Fig. 8, p. 17.

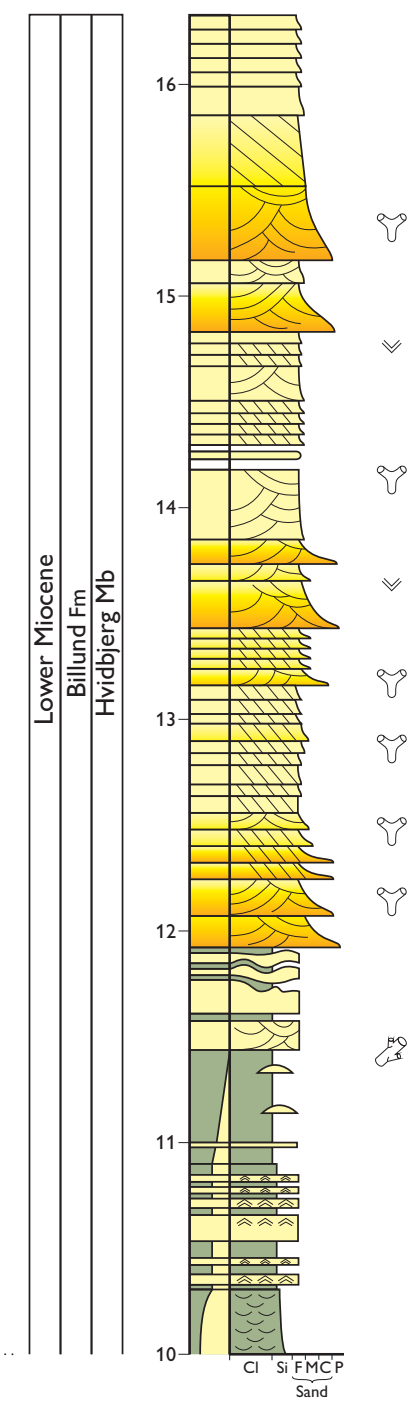


History. The Vejle Fjord Formation was defined by Larsen $\&$ Dinesen (1959). The formation was originally defined as the succession from the base of the Brejning Clay Member to the top of the Vejle Fjord Sand Member. For stratigraphic and practical reasons, the Brejning Clay Member is herein removed from the Vejle Fjord Formation and elevated to the status of formation (see above); redefinition of the Vejle Fjord Formation is therefore necessary. Revision is also needed because of the large amount of data acquired during the last decade, which has shed new light on the depositional system (Dybkjær \& Rasmussen 2000; Rasmussen \& Dybkjær 2005). Sediments referred by Christensen \& Ulleberg (1973) to the upper Sofienlund Formation are assigned here to the Vejle Fjord Formation; the Sofienlund Formation is abandoned.

Name. After Vejle Fjord in east Jylland (Fig. 1).

Type and reference sections. The type section is the Skansebakke outcrop at Brejning 55 $40^{\prime} 19.74^{\prime \prime} \mathrm{N}, 9^{\circ} 41^{\prime} 33.84^{\prime \prime} \mathrm{E}$; Figs 1,20). The outcrop reference section is defined at Dykær near Juelsminde (Figs 1, 21). Other exposures in the Vejle Fjord area are Brejning Hoved, Sanatoriet, Fakkegrav and Jensgård. It is further exposed at Hindsgavl near Middelfart, and the formation crops out at Skyum Bjerge, Lyby, Mogenstrup and Skanderup (Mors) in the Limfjorden area (Fig. 1). The secondary reference section is the Store Vorslunde borehole (DGU no. 104.2325) (Fig. 22), in the interval from 219 to $160 \mathrm{~m}$ (220-161 m MD).

Thickness. The formation is $c .20 \mathrm{~m}$ thick at the type locality though neither the base nor the top are seen; the formation is about $18 \mathrm{~m}$ thick in the nearby Andkær borehole (see Plate 1). In the western part of Jylland, it may reach a thickness of up to $c .100 \mathrm{~m}$, as exemplified by the Holstebro borehole (Plate 4).

Lithology. The Vejle Fjord Formation consists mainly of dark brown clayey silt (Fig. 23). In some areas, it is dominated by laminated, greenish-grey sand and dark brown, clayey silt. Sand stringers up to a few centimetres thick may occur. Locally, the formation is composed of waveinfluenced heterolithic mud and sand showing hummocky cross-stratification (Figs 24, 25); the heterolithic succession is commonly characterised by double clay layers and climbing ripples. Soft-sediment deformation structures occur locally. Trace fossils occur in places in the Vejle Fjord Formation.

Log characteristics. The formation is characterised by intermediate gamma-ray values (Fig. 22). The log pattern is ser-

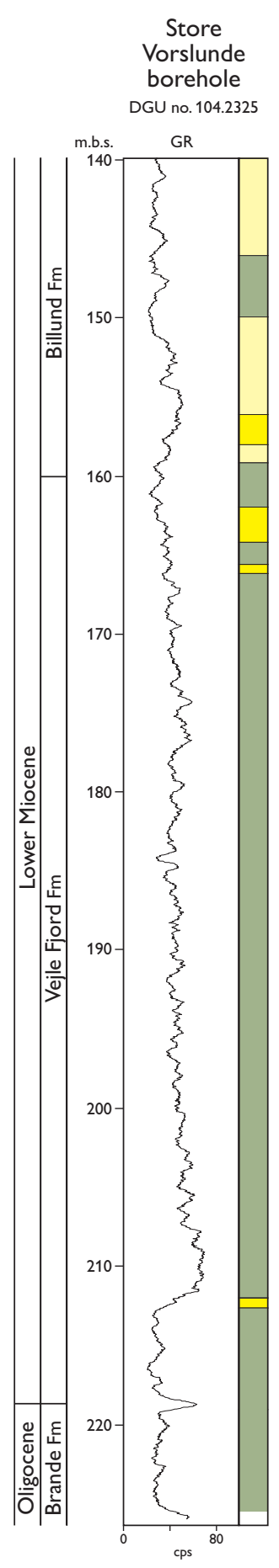

Fig. 22. Secondary reference section of the Vejle Fjord Formation: the interval from 219 to $160 \mathrm{~m}$ in the Store Vorslunde borehole, north-east of Vejle; for legend, see Fig. 8, p. 17.

rated and shows both decreasing- and increasing-upward trends throughout the succession.

Fossils. The Vejle Fjord Formation contains an impoverished mollusc fauna (Ravn 1907; Eriksen 1937; Schnetler \& 


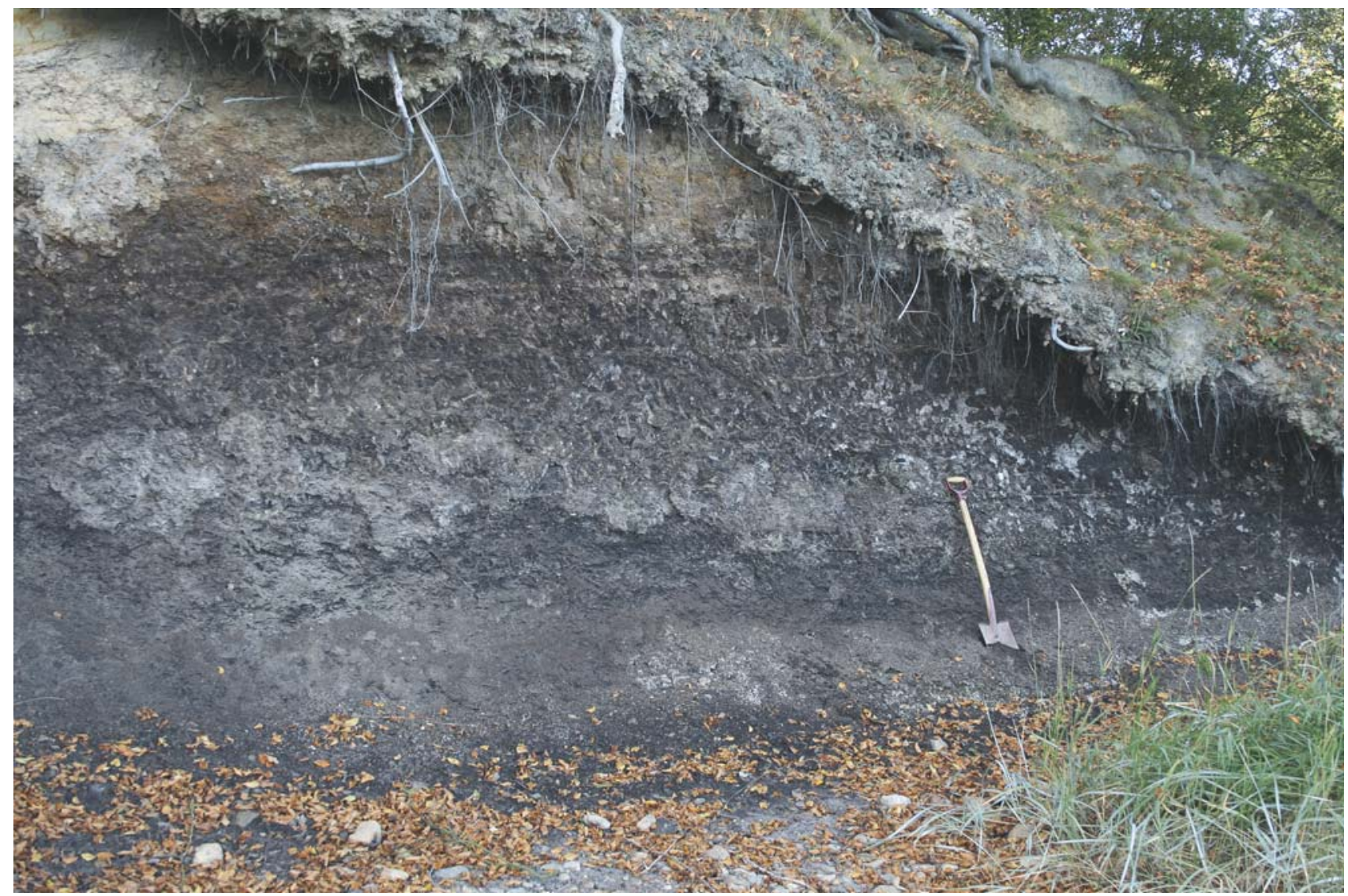

Fig. 23. Type section of the Vejle Fjord Formation at Skansebakke, Brejning; spade for scale (c. $1.3 \mathrm{~m}$ long).

Beyer 1987, 1990). The foraminifer fauna (Larsen \& Dinesen 1959; Laursen \& Kristoffersen 1999) and the dinocyst flora (Dybkjær 2004 a, b; Rasmussen \& Dybkjær 2005) are similarly impoverished within this formation, although the abundance of dinocysts is locally very high, albeit restricted to a few species.

Depositional environment. The Vejle Fjord Formation was deposited in a brackish to fully marine depositional environment. Brackish-water conditions predominated within the Norwegian-Danish Basin in the early phase of deposition as a consequence of the elevated Ringkøbing-Fyn High (Rasmussen \& Dybkjær 2005; E.S. Rasmussen 2009a). As sea level rose during the Early Miocene, fully marine conditions were re-established and the water depth was $c .100$ $m$ in the Norwegian-Danish Basin and probably less than $30 \mathrm{~m}$ on the Ringkøbing-Fyn High. Most of the Vejle Fjord Formation was deposited in a prodelta environment. The thickest developments of the formation are associated with inter-lobe depositional environments.

Boundaries. The lower boundary is typically sharp, being characterised by a change from greenish dark brown, glau- cony-rich, clayey silt to dark brown, clayey silt. A change in the degree of consolidation is observed at the boundary over much of Jylland, relatively loose sediments of the Vejle Fjord Formation overlying well-consolidated sediments of the Brejning Formation. A gravel layer is commonly found at the lower boundary. At the type locality, the lower boundary is marked by a distinct decrease in the content of glaucony (Larsen \& Dinesen 1959); the scattered glaucony grains found in the Vejle Fjord Formation are reworked (E.S. Rasmussen 1987). In central east Jylland, the boundary is commonly characterised by a marked change from the sand deposits of the Øksenrade Member (upper Brejning Formation) to dark brown, clayey silt of the Vejle Fjord Formation. Recognition of the lower boundary of the formation in subsurface data is based on both lithological and petrophysical data. The gamma-ray response at the boundary is variable. Where the upper Brejning Formation is mud-rich, as in the reference section for the formation (Fig. 8), gamma-ray values fall at the boundary to intermediate levels. In contrast, where the upper Brejning Formation is sand-rich (e.g. Fig. 14), or where the Vejle Fjord Formation overlies deltaic sands referred to the Billund Formation (e.g. Stakroge and Assing Mølleby boreholes, Plate 3), the 
Fig. 24. Hummocky cross-stratified sand in the upper part of the Vejle Fjord Formation at Jensgård, east of Horsens (Fig. 1); the dipping, weakly deformed attitude of these strata is due to glaciotectonics.

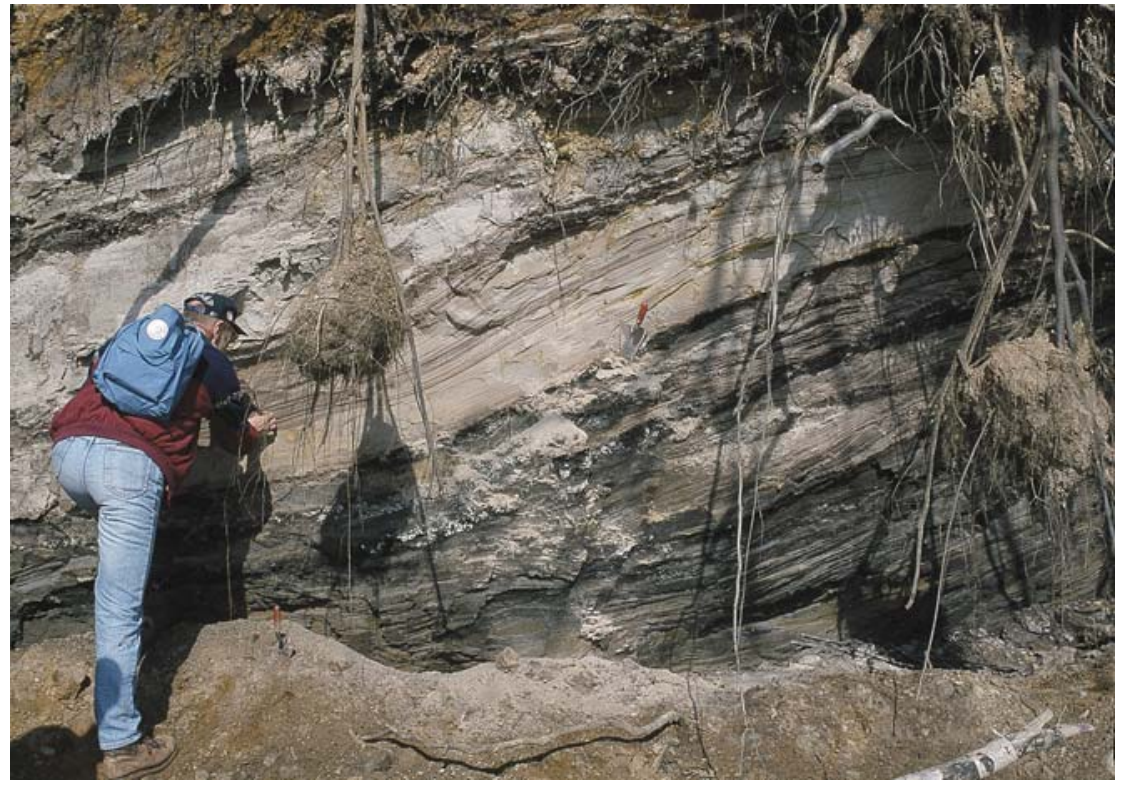

Fig 25. Hummocky cross-stratified sand with burrows (Scolicia isp.) from the Vejle Fjord Formation at Skyum (Fig. 1). Note that the sand layer is only burrowed in the upper part. Most of the Vejle Fjord Formation was deposited as alternating sand and clayey, silt layers, but due to bioturbation any stratification was later destroyed and only the thicker storm sand layers were preserved. Knife blade for scale.

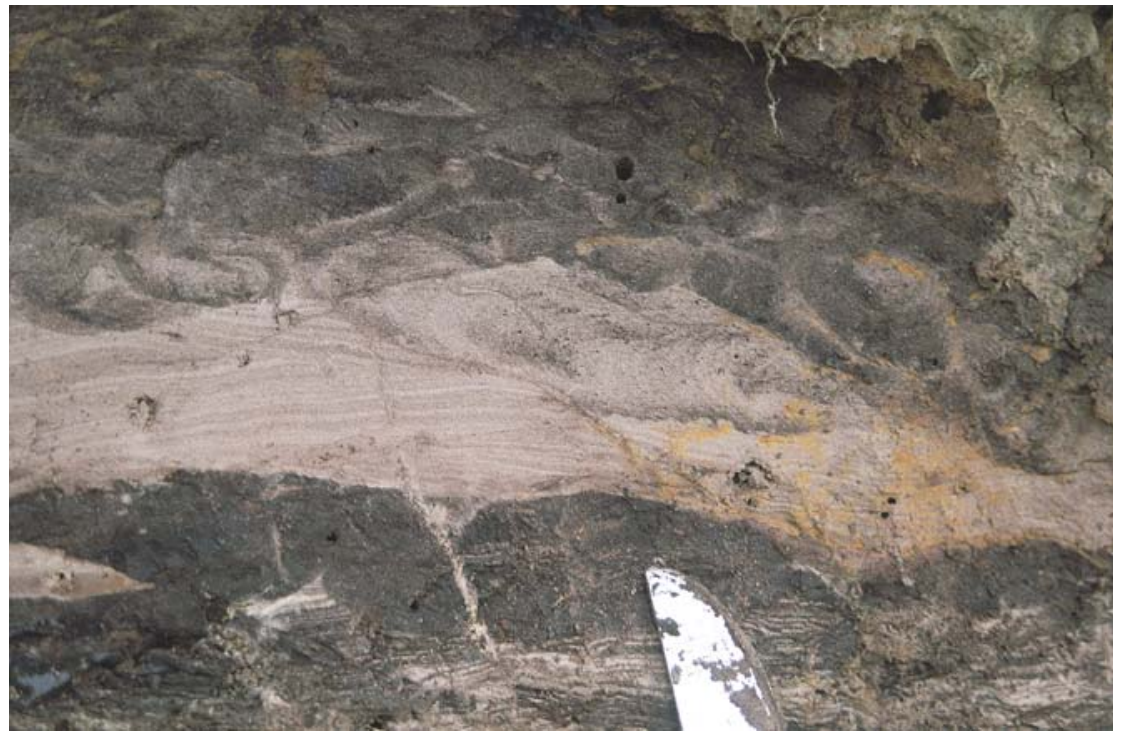

lower boundary is defined by an abrupt increase in gammaray values. Although in a number of wells the boundary can be difficult to position based on log data alone, lithological evidence (e.g. the presence of a gravel layer, glaucony content, clay colour and consolidation) can aid identification (e.g. Resen and Mausvig boreholes, Plate 5).

The upper boundary is typically defined where clayey, organic-rich silty sediments of the Vejle Fjord Formation are succeeded by sand-rich deposits ( $>75 \%$ sand) with a minimum thickness of $5 \mathrm{~m}$; the overlying sands are referred either to the Billund Formation or to the Kolding Fjord Member of the Klintinghoved Formation (e.g. Plate 6). On the gamma-ray log, this boundary may show a marked decrease in gamma-ray readings where overlain by a dis- crete sand unit, or a gradual but steady decrease in gammaray readings reflecting a transitional, interbedded, sandrich unit at the base of the overlying formation. Where the Billund Formation is absent in south and west Jylland, the Vejle Fjord Formation is succeeded by the clay-rich Klintinghoved Formation, and the boundary can be diffcult to locate in detail. In the Rødding and Føvling boreholes (Plate 8), for example, the two formations are lithologically very similar although the clayey silts of the Vejle Fjord Formation may be slightly more consolidated. The boundary can typically be picked on the gamma-ray $\log$, however, at a minor or moderate upward increase in values, commonly capping a weak coarsening-upward succession (decreasing-upward gamma-ray values). 
Distribution. The formation is present over much of Jylland with the exception of the southern and westernmost parts (Fig. 10B). The northern and eastern limit closely follows the overall outcrop pattern of the Miocene deposits (Fig. 4).

Biostratigraphy. The Chiropteridium galea and the Homotryblium spp. Dinocyst Zones of Dybkjær \& Piasecki (2010) are recorded in the Vejle Fjord Formation.

Geological age. The Vejle Fjord Formation is of Aquitanian (earliest Early Miocene) age.

Subdivision. The Vejle Fjord Formation includes the Skansebakke Member.

\section{Skansebakke Member}

revised member

History. Sediments referred here to the Skansebakke Member were formerly assigned to the Vejle Fjord Sand Member by Larsen \& Dinesen (1959); the member is renamed here in accordance with modern lithostratigraphic guidelines.

Name. After the outcrop of the type section at Skansebakke, Brejning, on the south coast of Vejle Fjord.

Type and reference sections. The type section is the outcrop

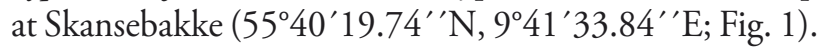
It is also exposed at Brejning Hoved, Sanatoriet, Fakkegrav and Dykær. The reference section is the interval from 91.10 to $79 \mathrm{~m}(92-79 \mathrm{~m} \mathrm{MD})$ in the Andkær borehole (DGU no. 125.2017; Fig. 26).

Thickness. At the type locality, the member is $c .7 \mathrm{~m}$ thick (top not seen); the member is $c .12 \mathrm{~m}$ thick at Brejning Hoved and $7 \mathrm{~m}$ thick at Sanatoriet.

Lithology. The Skansebakke Member consists of alternating layers of fine-grained, well-sorted, yellowish sand and brownish clay (Fig. 27). The sand beds are sharp-based and homogenous to evenly laminated. The sand beds are commonly capped by wave- and current-ripples. The trace fossils Arenicolites isp. and Macaronichnus isp. are common, and Ophiomorpha isp. is sporadically distributed (Friis et al. 1998). The pyrite content is relatively high compared to the overlying Billund Formation, resulting in the yellowish colour in exposed sections (M. Olivarius, personal communication 2010).

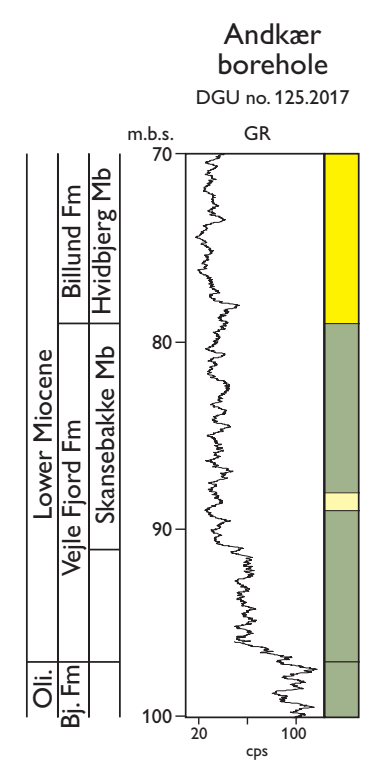

Fig. 26. The reference section of the Skansebakke Member is the interval from 91.10 to $79 \mathrm{~m}$ in the Andkær borehole. Note that the sand-rich nature of the interval indicated by the gamma-ray log is not reflected by the lithological sample data; for legend, see Fig. 8, p. 17. Bj.: Brejning. Oli.: Oligocene.

Log characteristics. The member is characterised by low gamma-ray readings with a serrated pattern (Fig. 26), reflecting the alternation of sand and mud beds.

Fossils. The Skansebakke Member contains an impoverished mollusc fauna (Ravn 1907; Eriksen 1937). The foraminifer fauna (Larsen \& Dinesen 1959) and the dinocyst flora (Dybkjær 2004 a, b; Rasmussen \& Dybkjær 2005) are also impoverished within this member.

Depositional environment. The Skansebakke Member is interpreted as having been deposited in a lagoonal depositional environment (Larsen \& Dinesen 1959; Friis et al. 1998; Rasmussen \& Dybkjær 2005). The sand beds were deposited as washover fans on a backbarrier flat during the main degradation of minor spit and barrier systems formed along elevated parts of the Ringkøbing-Fyn High.

Boundaries. The lower boundary is placed at the base of the first significant sand layer separating dark brown, clayey silt from a succession dominated by interbedded yellowish fine-grained sand and dark brown to brown, silty clay. On the gamma-ray log, the lower boundary is placed at a minor, but distinct decrease in gamma-ray readings. The upper boundary is defined by the distinct change from yellowish, fine-grained sand to white, fine- to medium-grained 
Fig. 27. Alternating fine-grained sand and clay of the Skansebakke Member at Skansebakke. The clay was deposited in a lagoon and the sand was deposited as washover fans during the degradation of a barrier island associated with an Early Miocene transgression. Spade for scale (c. $1.3 \mathrm{~m}$ long).

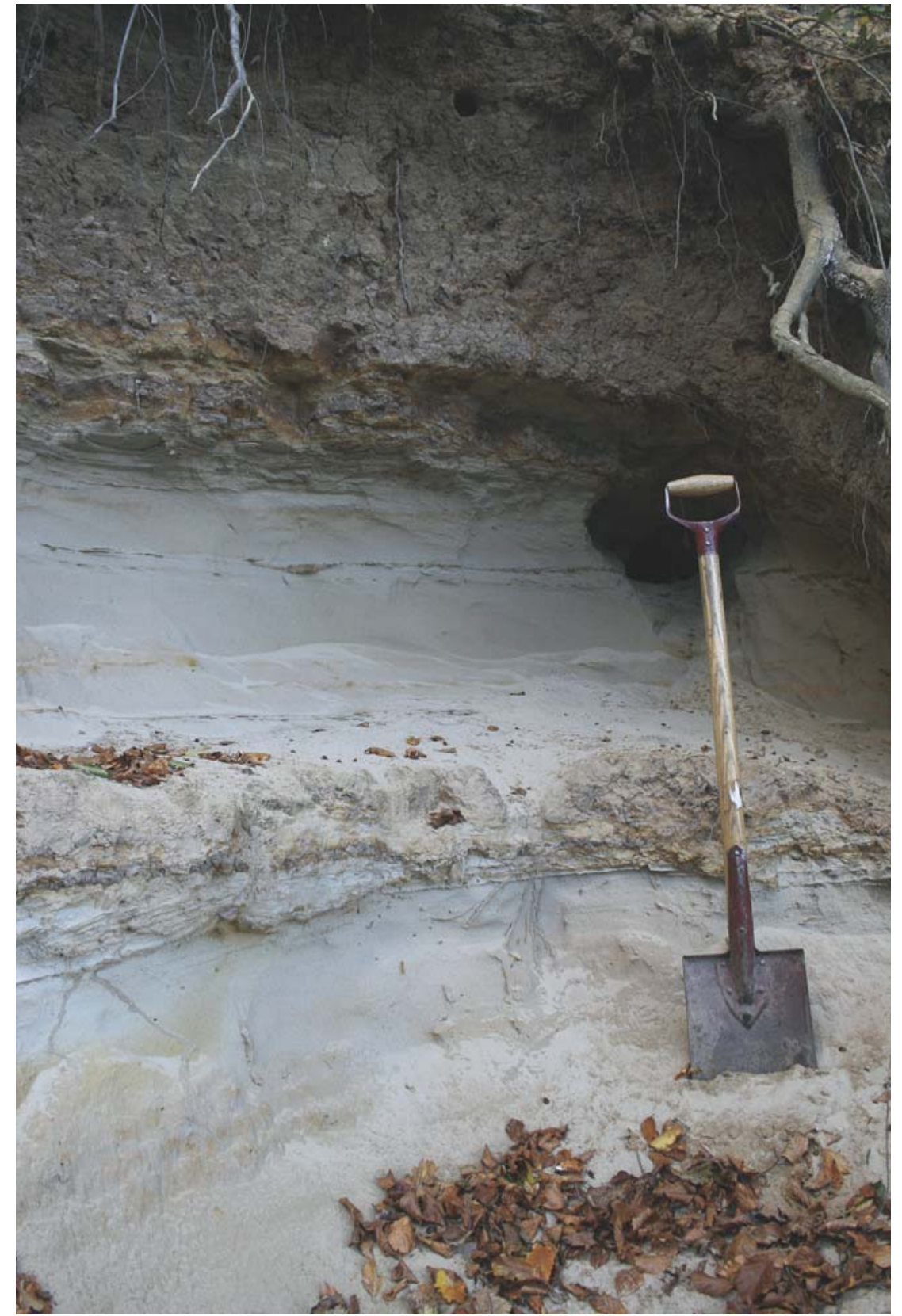

sand of the Hvidbjerg Member (Billund Formation). This boundary is only documented in the Andkær borehole where the gamma-ray log changes from serrated, low-intermediate gamma-ray readings of the Skansebakke Member to more consistently low gamma-ray values of the Hvidbjerg Member.

Distribution. The Skansebakke Member is restricted to central east Jylland and is exposed along the coast of Vejle
Fjord (Fig. 10B). In the subsurface, this member is only recognised in the Andkær borehole.

Biostratigraphy. The Chiropteridium galea and the Homotryblium spp. Dinocyst Zones of Dybkjær \& Piasecki (2010) are recorded in the Skansebakke Member.

Geological age. The Skansebakke Member is of Aquitanian (earliest Early Miocene) age. 


\section{Billund Formation}

new formation

Name. After the town of Billund (Fig. 1).

Type and reference sections. The type section of the Billund Formation is the interval from $235 \mathrm{~m}$ to $184 \mathrm{~m}$ (235-185 $\mathrm{m} \mathrm{MD}$ ) in the Billund borehole (DGU no. 114.1857, $55^{\circ} 43^{\prime} 08.53^{\prime \prime} \mathrm{N}, 9^{\circ} 08^{\prime} 33.98^{\prime \prime} \mathrm{E}$; Fig. 28). The reference section is the interval from 160 to $126 \mathrm{~m}(161-128 \mathrm{~m}$ $\mathrm{MD}$ ) in the Store Vorslunde borehole (DGU no. 104.2325; Fig. 28).

Thickness. In the type section, the formation is $51 \mathrm{~m}$ thick; the maximum thickness of $77 \mathrm{~m}$ has been found in the Hammerum borehole (Plate 6).

Lithology. The Billund Formation is primarily known from the subsurface but is exposed at a number of localities. In the Lillebælt area, the formation is exposed at Børup, Galsklint, Hindsgavl, Røjle and Rønshoved and in the Vejle Fjord region at Dykær, Fakkegrav and Hvidbjerg. In central Jylland, the formation can be observed at Addit, Salten and Voervadsbro, and at Søndbjerg and Lyby in northern Jylland. It is composed of fine- to coarse-grained sand with some gravel or pebble-rich beds (Fig. 29). The formation consists of almost pure quartz sand and includes clasts of quartzitic sandstone with subordinate mica and heavy minerals. Clasts of well-rounded chert occur locally. Pebbly horisons are common in the upper part and at the base of fluvial channels; clasts up to $4 \mathrm{~cm}$ occur in erosional scours within steep clinoform units. The formation is characterised by both coarsening-upward and fining-upward depositional patterns. Fine-grained sand units which are commonly hummocky cross-stratified, occur in the lower part of the formation and in eastern sections. The upper part is commonly dominated by swaley cross-stratified sand or sharp-based sand with a homogeneous or laminated lower part capped by wave ripples. The trace fossils Ophiomorpha isp. and Skolithos isp. are common (Fig. 29; Friis et al. 1998; Rasmussen \& Dybkjær 2005).

In the northern area, the formation is dominantly composed of cross-bedded sand with a range of set thicknesses. Soft sediment deformation structures are commonly seen. Some sections show an interval of interbedded, fine-grained, wave-rippled sands, muds and coals, sandwiched between two sand bodies with an overall sheet geometry. Root horizons and tree stumps are locally present (Weibel 1996; E.S. Rasmussen et al. 2007). In the eastern area, where the formation crops out, the sands are characterised by hum-

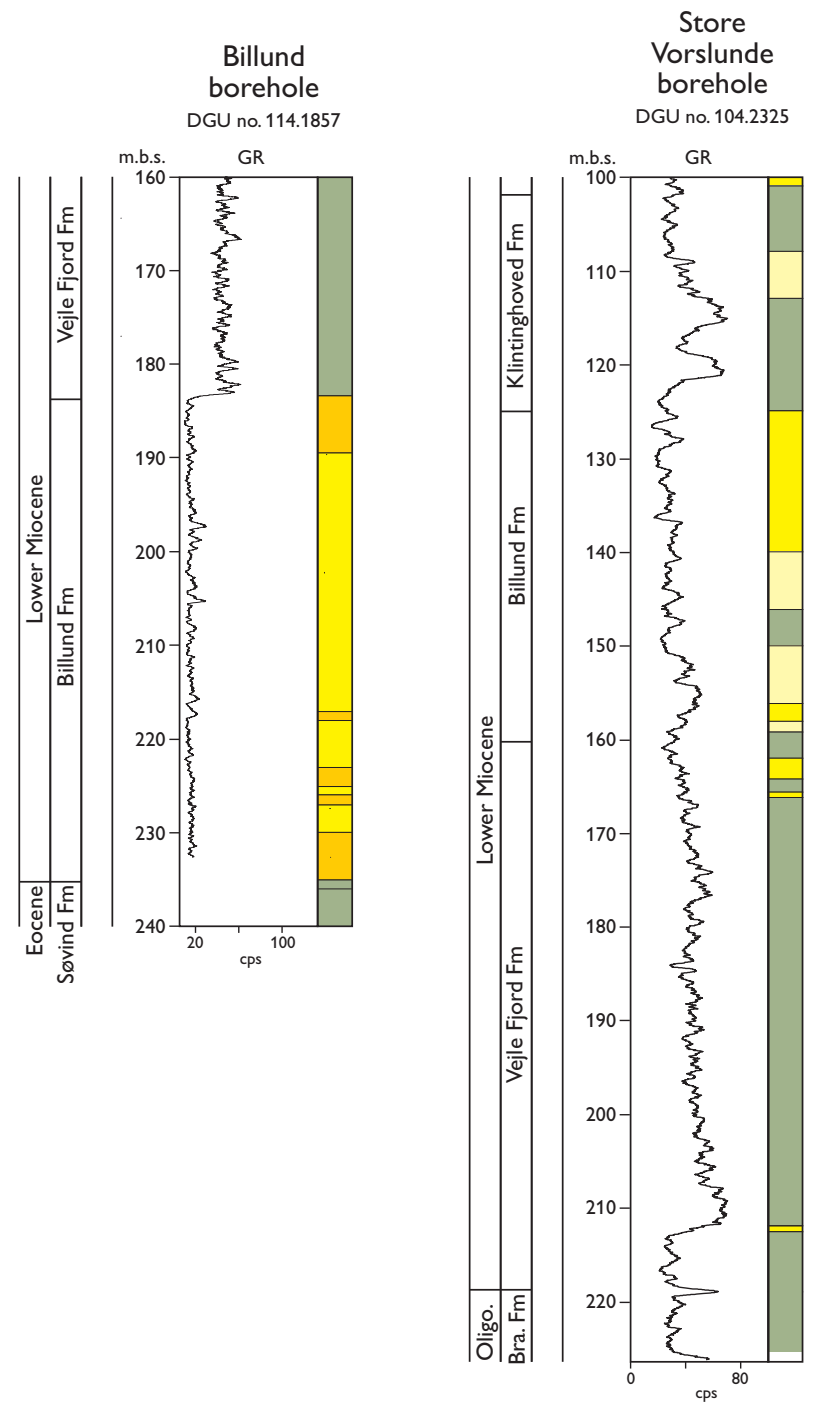

Fig. 28. Type and reference sections of the Billund Formation. The type section is the interval from 235 to $184 \mathrm{~m}$ in the Billund borehole and the reference section is the interval from 160 to $126 \mathrm{~m}$ in the Store Vorslunde borehole; for legend, see Fig. 8, p. 17. Bra.: Brande. Olig.: Oligocene.

mocky and swaley cross-stratification and homogeneous to laminated sand beds commonly capped by wave ripples; tidal bundles are also present (Fig. 30). The interbedded muds and heteroliths are dark brown in the northern part due to a high content of organic matter. In the southern area, the mud is light brown and typically thinner bedded, occurring interbedded with storm sand beds.

Log characteristics. The formation is generally characterised by low gamma-ray values. In some boreholes, the lower part is characterised by a serrated lower part with gener- 


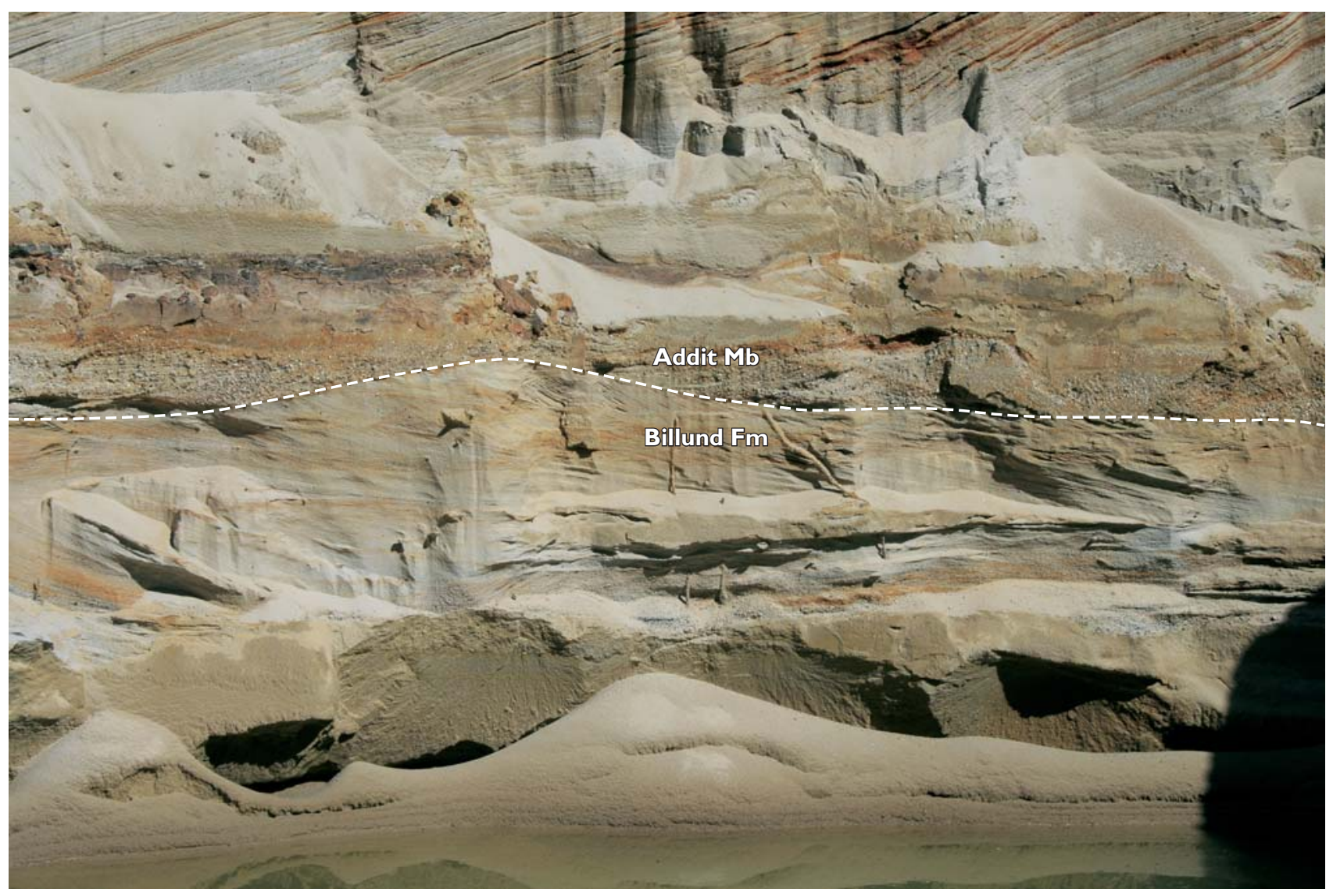

Fig. 29. Marine sand and fluvial gravel and sand of the Billund Formation exposed at Voervadsbro. Note the Skolithos burrows (centre) indicating a marine depositional environment. The lower boundary of the fluvial deposits (Addit Member) is at the base of the gravel layer (dashed line). The illustrated section is $2 \mathrm{~m}$ high.

ally higher gamma-ray values (e.g. Hammerum borehole, Plate 6). In the type borehole, the Billund Formation shows consistently low gamma-ray readings (Fig. 28).

Fossils. The Billund Formation contains fossil wood (Weibel 1996), leaves and seeds (Ravn 1907) but also marine molluscs (e.g. in the 'Brøndum Blokke'; Friis 1995). Foraminifers and dinocysts are present locally (Laursen \& Kristoffersen 1999; E.S. Rasmussen et al. 2006).

Depositional environment. The Billund Formation was deposited as a delta system prograding from the north and north-east towards the south and south-east. The well-constrained palaeogeographical setting is based on high-resolution seismic data and facies distribution (Rasmussen \& Dybkjær 2005; Hansen \& Rasmussen 2008). Progradation took place in association with an Early Miocene inversion phase (E.S. Rasmussen 2009a), and the distribution of the delta lobes was consequently strongly controlled by the antecedent topography. Two major lobes, the Ringkøbing and Brande lobes, were mapped by Hansen \& Rasmussen (2008). The Billund delta complex was deposited as wavedominated deltas (Rasmussen \& Dybkjær 2005; Hansen \& Rasmussen 2008; E.S. Rasmussen 2009b). The southeastward longshore currents that prevailed during the Early Miocene resulted in deposition of spit and barrier complexes south-east of the main delta lobes (Hvidbjerg Member). The most coarse-grained part was deposited in steeply dipping clinoformal packages deposited during falling sea-level (Hansen \& Rasmussen 2008; E.S. Rasmussen 2009b) and within incised valleys (Addit Member).

Boundaries. The lower boundary is defined by a change from clayey, organic-rich silty sediments of the Vejle Fjord Formation to sand-rich deposits; as noted earlier, recognition of the Billund Formation requires a minimum sand thickness of $5 \mathrm{~m}$ and a sand-mud ratio of over $75 \%$. Locally, for example in the type section at Billund, sand referred to the Billund Formation overlies the Eocene Søvind Marl; in such sections, the base of the formation is a significant 


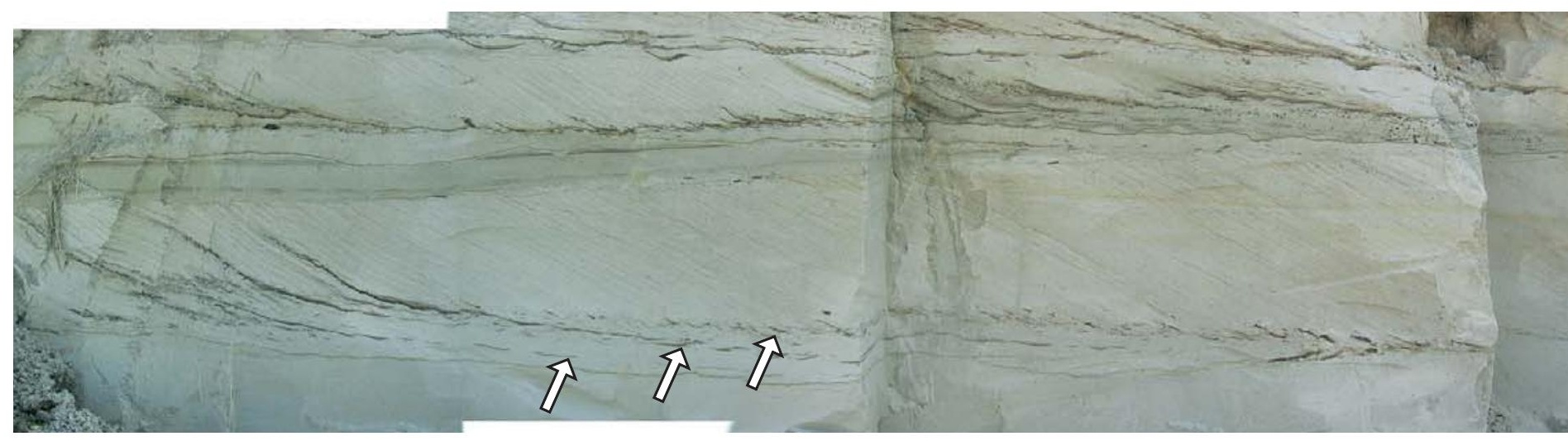

hiatal surface. On the gamma-ray log, the lower boundary is identified by a marked decrease in gamma-ray readings. In some sections (e.g. Store Vorslunde, Fasterholt boreholes, Plate 2), the shift from mud- to sand-rich deposits is gradational and reflected by a gradual but steady decrease in gamma-ray readings; the boundary is placed according to the criteria described above.

The upper boundary is placed at the change from sandrich deposits of the Billund Formation to the predominantly dark brown, silty clays of the Klintinghoved Formation or the Vejle Fjord Formation. At outcrop, the boundary is often erosive and overlain by a gravel lag or sand layer showing a fining-upward trend; the base of the gravel lag or sand layer forms the upper boundary. On the gamma-ray log, the upper boundary shows a variety of motifs. In boreholes where the sandy Billund Formation is succeeded by mud-dominated facies of the Klintinghoved Formation, the boundary is defined at an abrupt increase in values. Where the lower Klintinghoved Formation includes gravel and sand layers succeeded by mud-rich facies (e.g. Egtved borehole, Plate 7), the boundary is placed at the base of a prominent shift to lower gamma-ray values that is succeeded by a general upward increase in values. Where gamma-ray readings are strongly serrated, the boundary is placed at the base of the most coarse-grained sand or gravel layer found in the lithological descriptions.

Distribution. The Billund Formation is distributed in central Jylland (Fig. 10C). Although beyond the formal boundaries of the formation, a sand-rich succession reported from the subsurface of the North Sea may represent the westernmost lobe of the Billund delta complex (Hansen \& Rasmussen 2008).

Biostratigraphy. The Chiropteridium galea and the Homotryblium spp. Dinocyst Zones of Dybkjær \& Piasecki (2010) are recorded in the Billund Formation.
Geological age. The Billund Formation is of Aquitanian (earliest Early Miocene) age.

Subdivision. The Billund Formation includes two members: the Hvidbjerg Member and the Addit Member.

\section{Hvidbjerg Member}

new member

General. The new Hvidbjerg Member represents a particular facies variant of the Billund Formation, dominated by spit deposits. The diagnostic features are only convincingly recognised at outcrop; the member is thus only recognised in the Vejle Fjord area in outcrops and closely adjacent boreholes. The member also crops out at Søndbjerg and Lyby in the Limfjorden area (Fig. 1).

History. The succession of white sands at Hvidbjerg Strand was studied by Larsen \& Dinesen (1959); these authors refrained from including the 'Hvidbjerg Sand' in the Vejle Fjord Formation due to contrasting heavy mineral suites in these two units.

Name. After the outcrop at Hvidbjerg Strand on the south coast of Vejle Fjord (Fig. 1).

Type and reference sections. The type section of the Hvidbjerg Member is the coastal exposure at Hvidbjerg Strand on the south coast of Vejle Fjord $\left(55^{\circ} 38^{\prime} 24.58^{\prime \prime} \mathrm{N}\right.$, 9 44'39.22' E; Figs 31, 33). Other exposures are at Sanatoriet, Fakkegrav and Dykær in the Vejle Fjord area, at Pjedsted north-west of Fredericia and at Hindsgavl, Galsklint, Børup and Rønshoved in the Lillebælt area. The sand crops out at two localities in the Limfjorden area, at Søndbjerg and Lyby. The reference section is the interval 


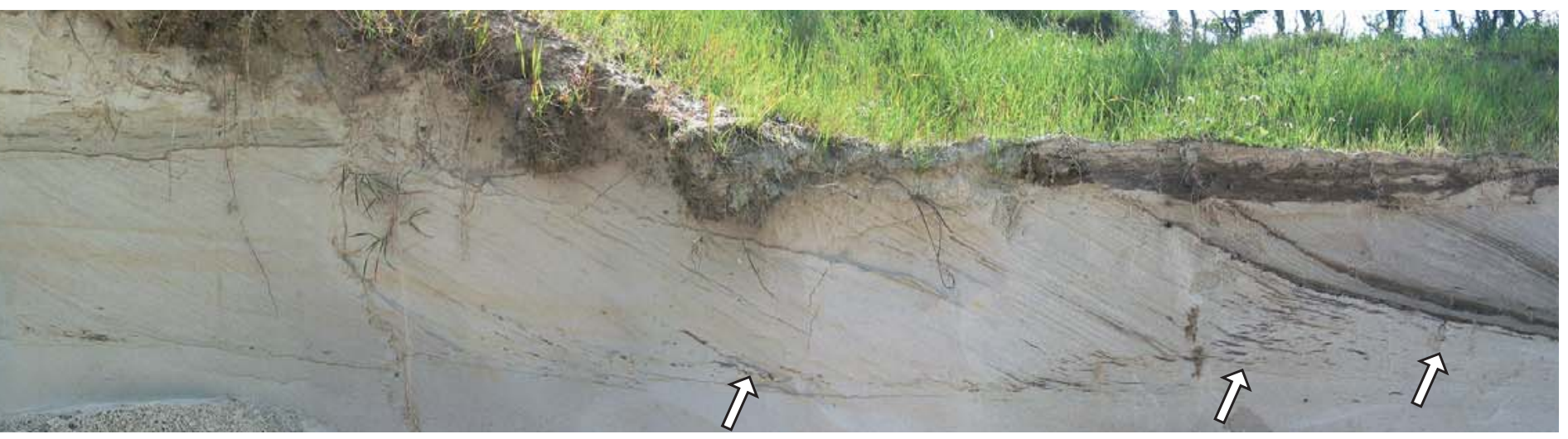

Fig. 30. Tidal bundles in the Hvidbjerg Member exposed at Pjedsted, north-west of Fredericia (Fig. 1). The cross-bedding dips towards the south-west and thus reflects ebb current flow. Note the clay drapes and preserved bottom sets (arrows) recording sedimentation during neap tides. The cross-bedded section thus represents a neap-spring-neap cycle (i.e. $c$. one and a half months). The section is $1.5 \mathrm{~m}$ high. Photograph courtesy of Ole Rønø Clausen.

from 79 to $58 \mathrm{~m}(79-58 \mathrm{~m} \mathrm{MD})$ in the Andkær borehole (DGU no. 125.2017; Fig. 32).

Thickness. The member is $28 \mathrm{~m}$ thick in the type section at Hvidbjerg (Fig. 31). In the outcrops of the Lillebælt area, it can attain $13 \mathrm{~m}$ but is rarely thicker than $6 \mathrm{~m}$. In the subsurface, the member is recognised in the Andkær borehole (reference section, $21 \mathrm{~m}$ thick) and the Lillebælt borehole $(c .11 \mathrm{~m})$.

Lithology. The Hvidbjerg Member consists of white, fineto medium-grained sand with a few pebble layers (Fig. 33). The sand beds are dominated by sharp-based, structureless to evenly laminated sand capped by wave ripples. Hummocky and swaley cross-stratification are common in the southern area, near Lillebælt (Fig. 34). Trough and tabular cross-stratified sand beds occur locally as well as tidal bundles. The cross-bedding indicates bipolar current directions towards the north-east and south-west. Thin, light brown clay layers are common in the southern part. North of Hvidbjerg, a dark brown, mud-dominated unit up to 3 $\mathrm{m}$ thick is recognised, locally capped by wood debris. The trace fossils Ophiomopha isp. and Skolithos isp. occur locally. The Hvidbjerg Member differs from the remainder of the Billund Formation in relation to its better sorting and its dominantly aggradational stacking pattern (e.g. Rasmussen \& Dybkjær 2005).

Log characteristics. The member is characterised by low gamma-ray readings (Fig. 32). High gamma-ray readings may be recorded where clay-rich, lagoonal deposits occur.
Fossils. A relatively rich dinocyst assemblage occurs in the Hvidbjerg Member (Dybkjær 2004a; Rasmussen \& Dybkjær 2005).

Depositional environment. Deposition took place in a stormdominated shoreface environment associated with spit development, south-east of the main Billund delta lobes. The core of a spit system crops out at Hvidbjerg. North of Hvidbjerg, shoreface sands alternate with mud-rich lagoonal deposits (Fig. 21). Tidal inlet deposits are observed at Dykær and Pjedsted where flood- and ebb-dominated systems, respectively, are recorded (Fig. 30).

Boundaries. The member overlies the Vejle Fjord Formation; the lower boundary is marked by a change from black, organic-rich, clayey silt to white sand. At Hvidbjerg, the lower boundary is erosional (Fig. 31). Where the member is superimposed on the Skansebakke Member of the Vejle Fjord Formation, the lower boundary is identified by a change from yellowish sands of the Skansebakke Member to white sands of the Hvidbjerg Member. On the gammaray $\log$, the boundary is characterised by a distinct shift towards low gamma-ray readings.

The upper boundary is placed at the change from sandrich deposits of the Hvidbjerg Member to the predominantly dark brown, silty clay of the Klintinghoved Formation. The boundary is often erosional and overlain by a gravel lag or sand layer showing a fining-upward trend; the gravel lag commonly contains of clasts up to $4 \mathrm{~cm}$ in diameter. The base of the gravel lag forms the upper boundary of the member. The gamma-ray readings may be characterised by an abrupt increase followed by a gradual decrease in values or a marked decrease in gamma-ray readings suc- 

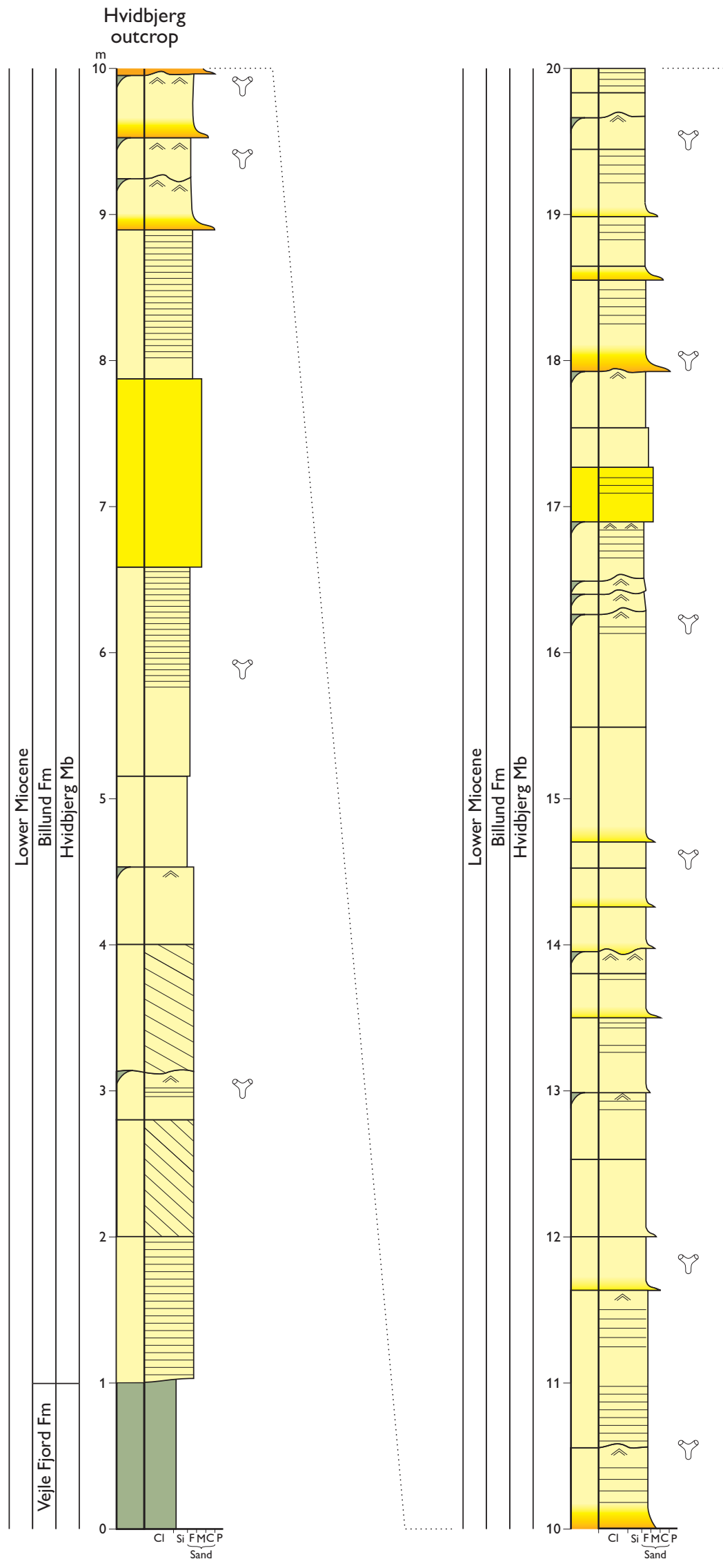

Fig. 31. Type section of the Hvidbjerg Member from the coastal exposures at Hvidbjerg, south-east of Vejle (Fig. 1); for legend, see Fig. 8, p. 17.

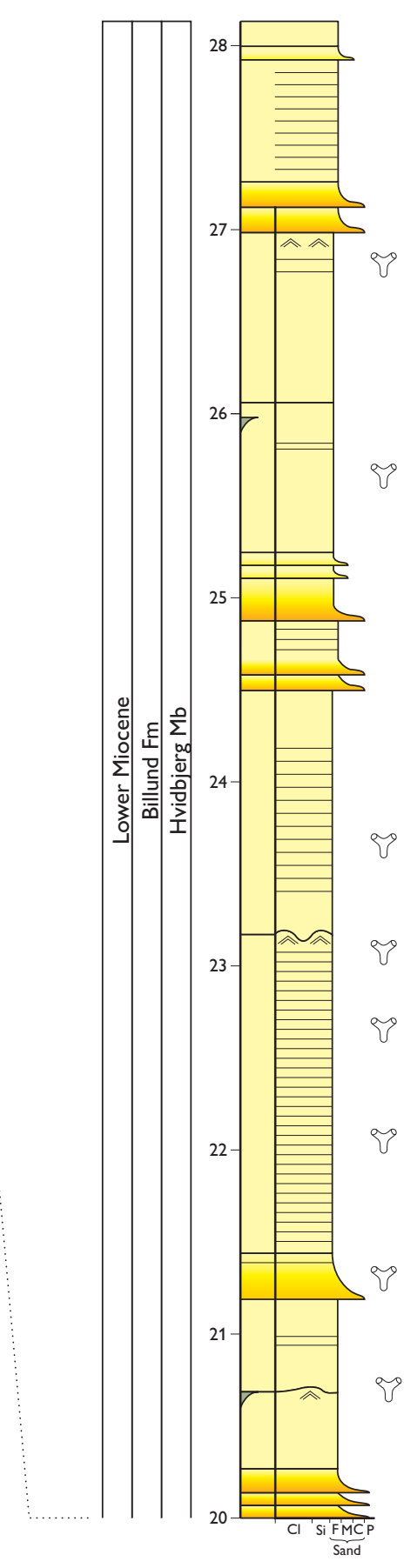




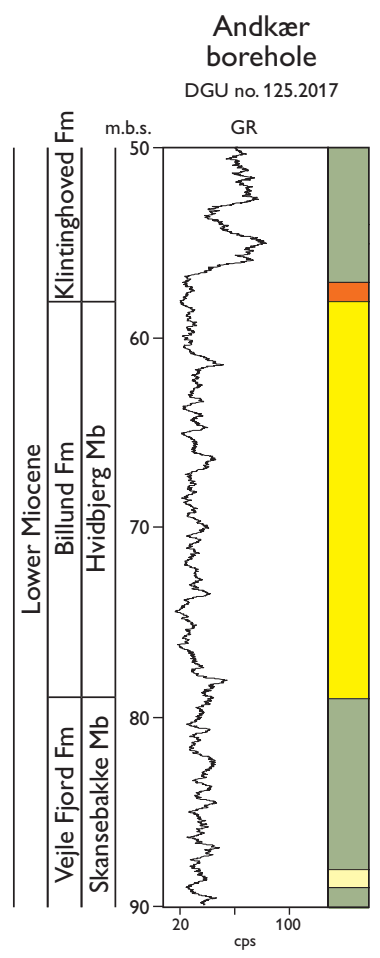

ceeded by a gradual increase (e.g. Andkær borehole, Fig. 32 ); the boundary is placed at the lowest gamma-ray response.

Distribution. The Hvidbjerg Member is present in east Jylland and has also been found at Søndbjerg in northwest Jylland (Fig. 10C).

Biostratigraphy. The Chiropteridium galea and the Homotryblium spp. Dinocyst Zones of Dybkjær \& Piasecki (2010) are recorded in the Hvidbjerg Member.

Geological age. The Hvidbjerg Member is of Aquitanian (earliest Early Miocene) age.

Fig. 32. Reference section of the Hvidbjerg Member in the Andkær borehole (79-58 m); for legend, see Fig. 8, p. 17.

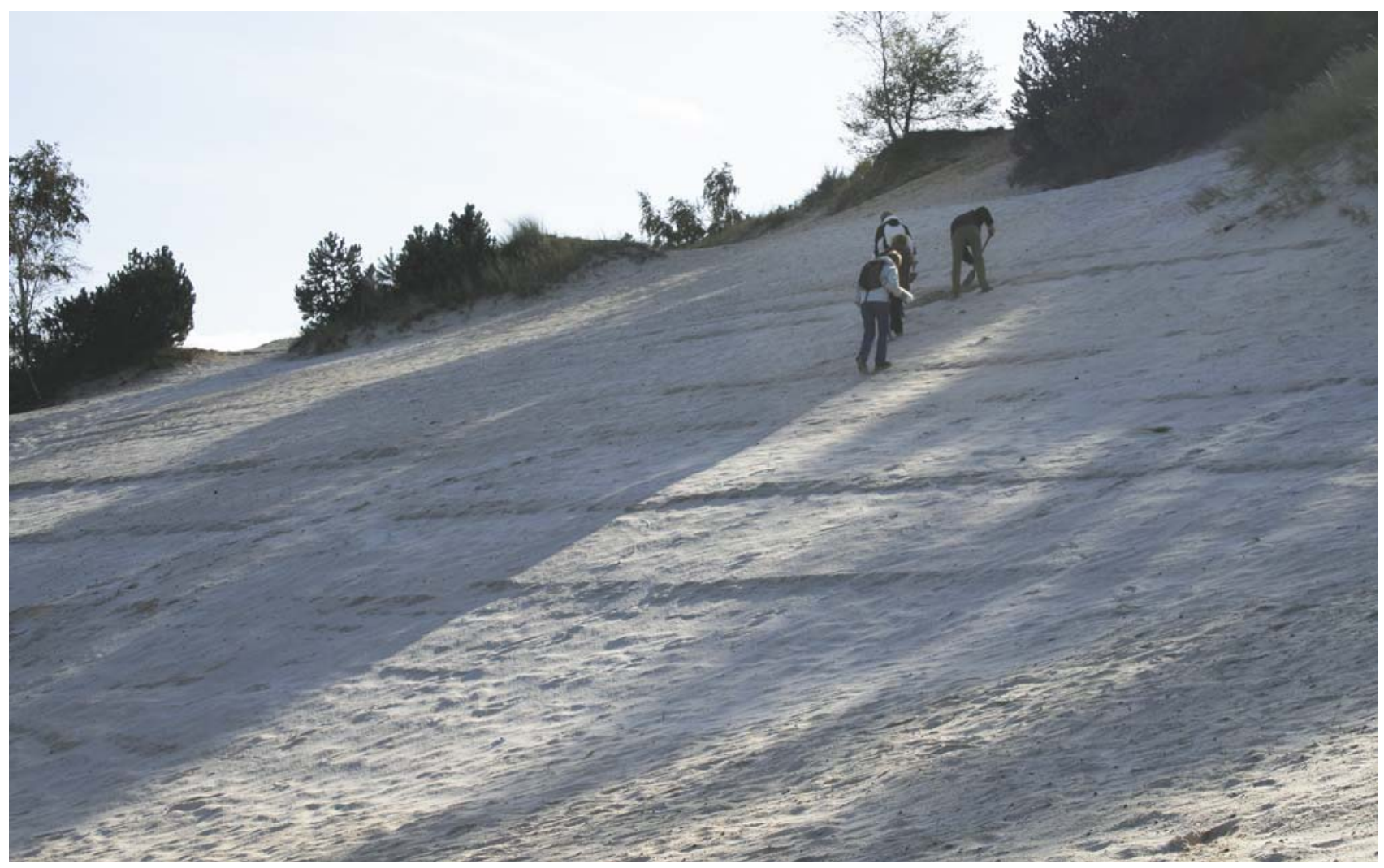

Fig. 33. The c. $27 \mathrm{~m}$ of white sand exposed at Hvidbjerg represents deposition on a spit system east of the main delta lobe of the Billund Formation. Note the stratification defined by the most bioturbated parts of the succession; photograph illustrates the upper levels of the Hvidbjerg Member shown in Fig. 31. 


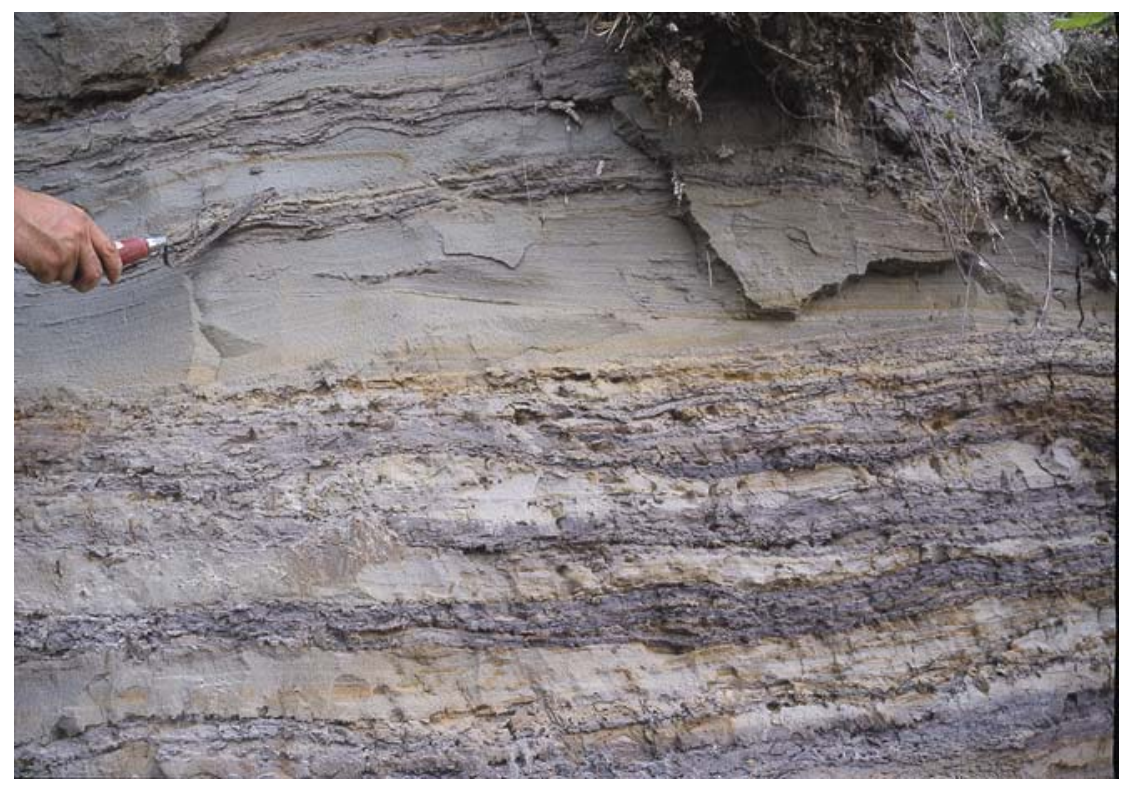

Fig. 34. Hummocky cross-stratified sand of the Billund Formation (Hvidbjerg Member) overlying interbedded, hummocky cross-stratified sands and clays of the Vejle Fjord Formation; Hindsgavl, near Middlefart (Fig. 1).

\section{Addit Member}

new member

History. Sand-rich fluvial and coal-bearing deposits in the Silkeborg area were first studied by Hartz (1909). He correlated the succession with Lower Miocene coal-bearing deposits in Schleswig-Holstein. L.B. Rasmussen (1961) indicated that the fluvio-deltaic sediments of the Silkeborg-Skanderborg area could be of similar age to the Ribe Formation as defined from the Arnum-1 well in southern Jylland. Studies of the succession in gravel pits south of Silkeborg were carried out during the 1970s and 1980s, focusing on the depositional environment and diagenesis (Friis 1976, 1995; Hansen 1985; Hansen 1995; Jesse 1995). These studies referred the deposits to the Middle Miocene Odderup Formation, although Friis (1995) was aware of the problems inherent in this correlation. Re-investigation of the Salten inland cliff and the gravel pits at Addit and Voervadsbro, including biostratigraphic analysis based on dinocysts, revealed that the succession is Early Miocene in age and should be correlated with the Vejle Fjord Formation - Billund Formation depositional phase (E.S.Rasmussen et al. 2006).

Name. After the village of Addit, south-south-west of Århus (Fig. 1).

Type and reference sections. The type section of the Addit Member is defined as the Dansand gravel pit at Addit $\left(56^{\circ} 02^{\prime} 26.33^{\prime \prime} \mathrm{N}, 9^{\circ} 37^{\prime} 59.62^{\prime \prime} \mathrm{E}\right.$; Fig. 35). The member is also exposed in the Voervadsbro gravel pit which forms the primary reference section (Fig. 36), and in the inland cliff at Salten. The secondary reference section is the interval from 117 to 55 m (119-55 m MD) in the Addit Mark borehole (DGU no. 97.928; Fig. 37).

Thickness. In the type section, the Addit Member is over 33 m thick; neither top nor base are seen. In the Addit borehole nearby (Fig. 1), the member is $50 \mathrm{~m}$ thick (Plate 6) and $62 \mathrm{~m}$ was penetrated in the borehole at Addit Mark (Fig. 37; Plate 6). Where well developed in central and north-east Jylland, the member is typically $20-50 \mathrm{~m}$ thick (see Plates 1, 2, 5, 6).

Lithology. The succession is typically composed of two sandand gravel-rich units separated by fine-grained, sandy and clayey sediments, commonly with intercalated coal layers (Figs 35, 36, 38; Plates 1, 6), though the middle heterogeneous unit may be absent or poorly developed. The sands consist almost solely of quartz and quartzitic sandstone lithic grains, with minor content of mica and heavy minerals; clasts of well-rounded chert may occur. The two sandrich units are characterised by fining-upward trends and possess sheet geometry. The lower part of each unit consists of trough cross-stratified, coarse-grained sand and gravel alternating with large-scale cross-stratified sand (Figs 35, 36, 39). Upwards, these sand-rich units are progressively dominated by tabular co-sets of cross-stratified sand. The sand-rich succession may be capped by fine-grained, crossbedded sand showing lateral accretion structures. The coalbearing, fine-grained sand and clay layer, sandwiched between the coarser units, consists of cross-bedded sand and alternating thin, rippled, fine-grained sand and clay layers. Bioturbation is observed rarely. Wood fragments are abun- 

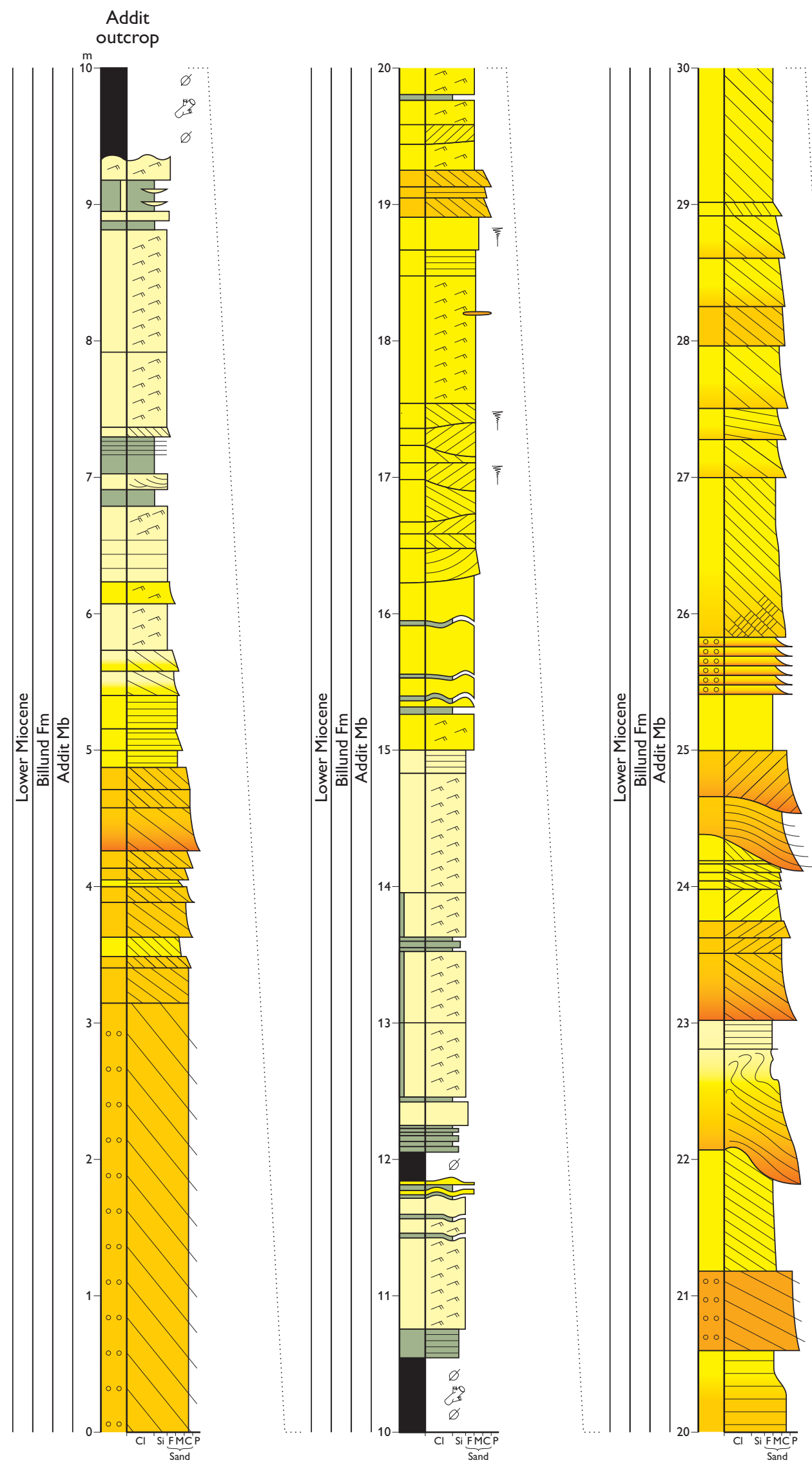

Fig. 35. Type section of the Addit Member in the Addit gravel pit, south-east of Silkeborg (Fig. 1); for legend, see Fig. 8, p. 17.

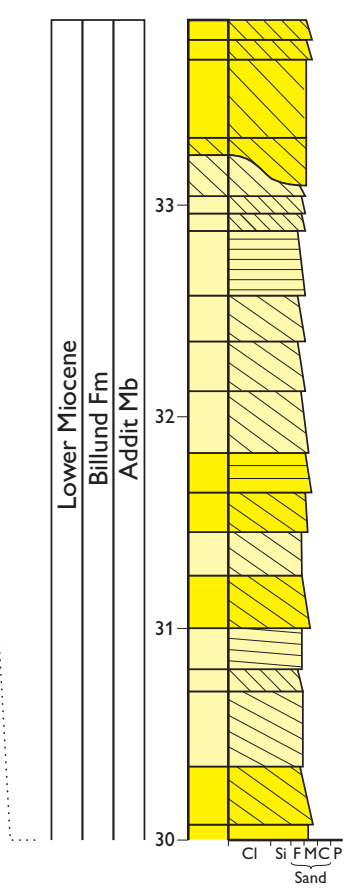



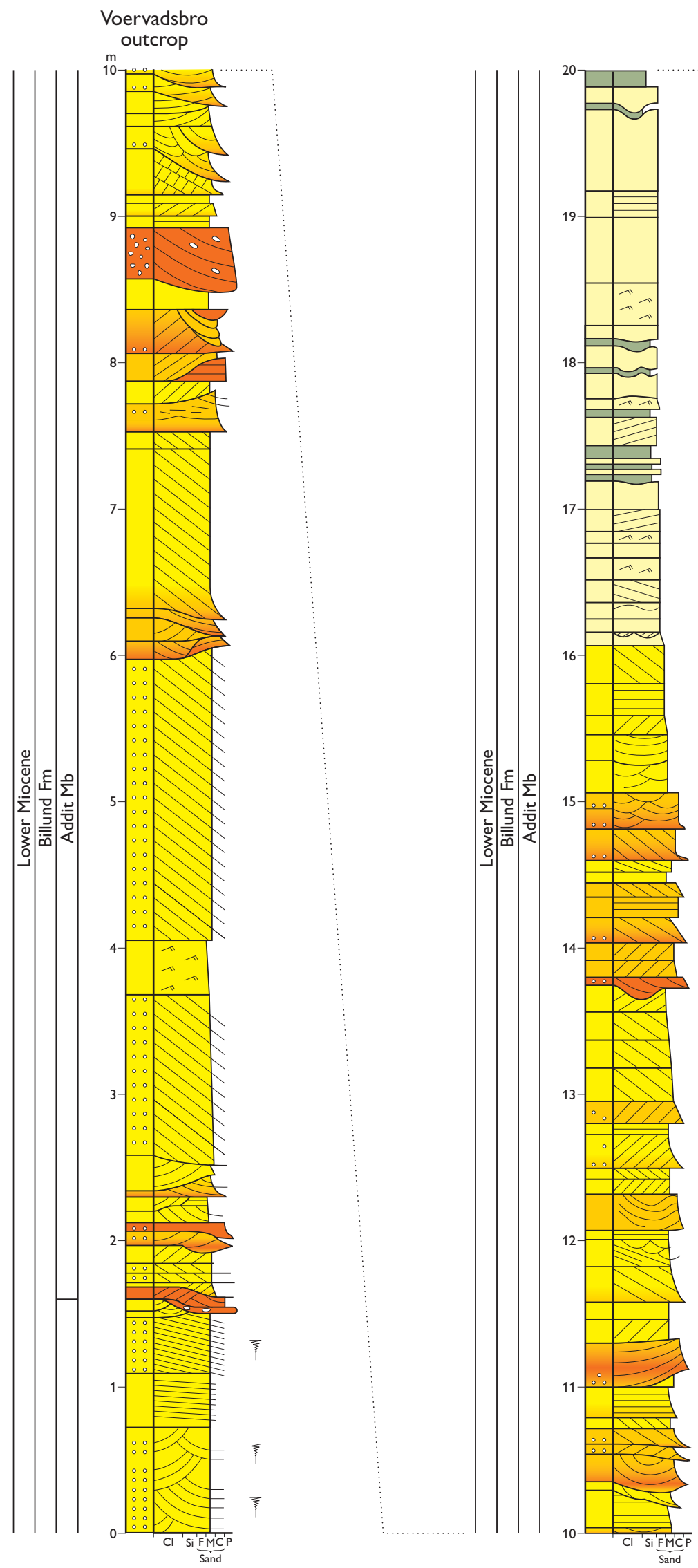

Fig. 36. Primary reference section of the Addit Member in the Voervadsbro gravel pit, south-east of Silkeborg (Fig. 1), where the lower part of the member is exposed; for legend, see Fig. 8, p. 17.

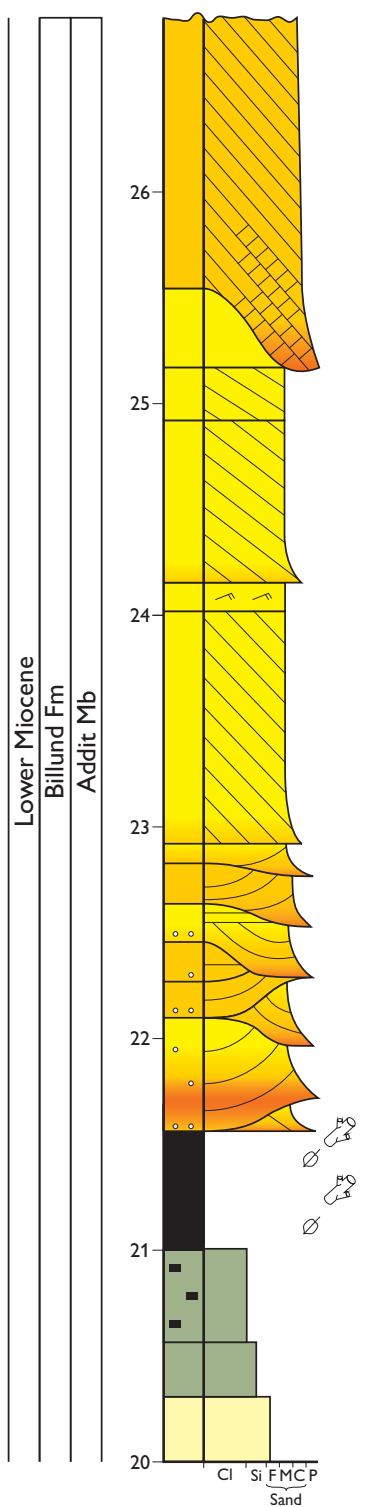


dant at certain horizons and petrified wood is common at Voervadsbro (Weibel 1996).

Log characteristics. The member is characterised by low gamma-ray readings, especially in the lower part (Fig. 37).

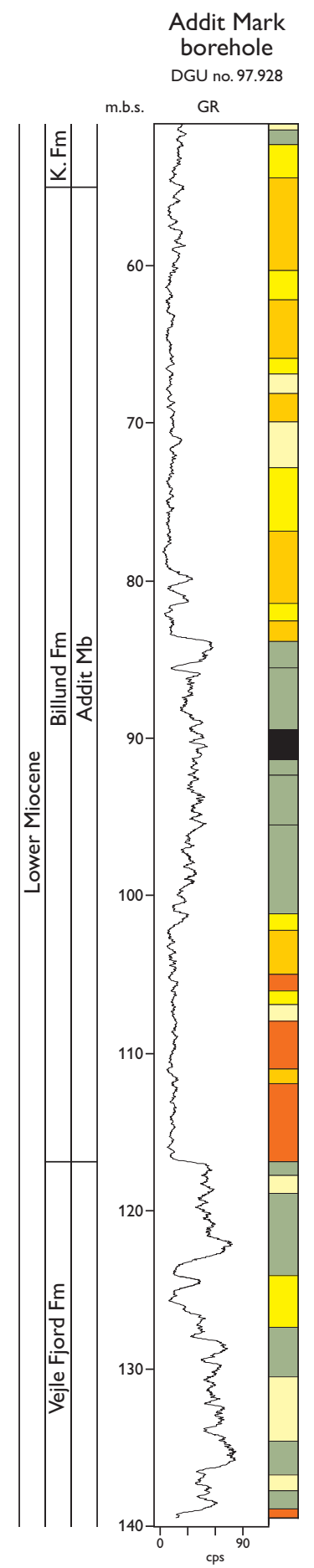

Fig. 37. Secondary reference section of the Addit Member in the Addit Mark borehole (117-55 m); for legend, see Fig. 8, p. 17. K.: Klintinghoved.
The sand-rich part is commonly characterised by a slight upward increase in gamma-ray values. A moderate-high gamma-ray response commonly characterises the middle part of the member, reflecting the clay-rich and coal-bearing deposits at this level.

Fossils. The Addit Member contains fossil wood (Weibel 1996), leaves and seeds (Ravn 1907). Dinocysts occur very sporadically in the Addit Member (Dybkjær 2004a, b; E.S. Rasmussen et al. 2006).

Depositional environment. The lower sands of the member were deposited as migrating three-dimensional dunes (main channel) and migrating unit and compound bars in a braided fluvial system (Hansen 1985; Hansen 1995; E.S. Rasmussen et al. 2006). The upper part of the member was deposited as migrating two-dimensional dunes; sedimentary structures such as cross-bedded sand beds with preserved bottomsets and normally graded foresets indicate tidal influence (Pontén \& Plink-Björklund 2007). The upper part of the sand succession, showing lateral accretion, was laid down in a point bar of a meandering fluvial system. The fine-grained middle part of the member was deposited in a flood plain and lake environment that was occasionally flooded by the sea as indicated by the rare presence of dinocysts and Ophiomorpha trace fossils.

Boundaries. Where the Addit Member directly overlies the Vejle Fjord Formation, the lower boundary is marked by an abrupt change from dark brown, silty clay or clayey silt to grey, coarse-grained sand and gravel (Fig. 37; Plates 1, 2, 6). Where the Addit Member overlies the Hvidbjerg Member, the boundary is marked by an erosional boundary where white, fine- to medium-grained sand is overlain by gravel (Fig. 29). On the gamma-ray log, the lower boundary is shown as a prominent shift on the gamma-ray log where the Addit Member overlies the Vejle Fjord Formation. Where the member overlies the Hvidbjerg Member, the lower boundary is placed at the change of gamma-ray reading from a gradual upward decrease in gamma-ray readings to consistently low or decreasing-upward gamma-ray readings.

The upper boundary is placed at the change from sandrich deposits of the Addit Member to predominantly dark brown, silty clays of the Klintinghoved Formation. The boundary may be erosional, being overlain by a gravel lag or sand layer showing a fining-upward trend; the gravel lag commonly contains clasts up to $4 \mathrm{~cm}$ in diameter. The base of the gravel lag or sand layer forms the upper boundary of the member. The gamma-ray log is commonly characterised by an abrupt increase in gamma-ray values (e.g. 


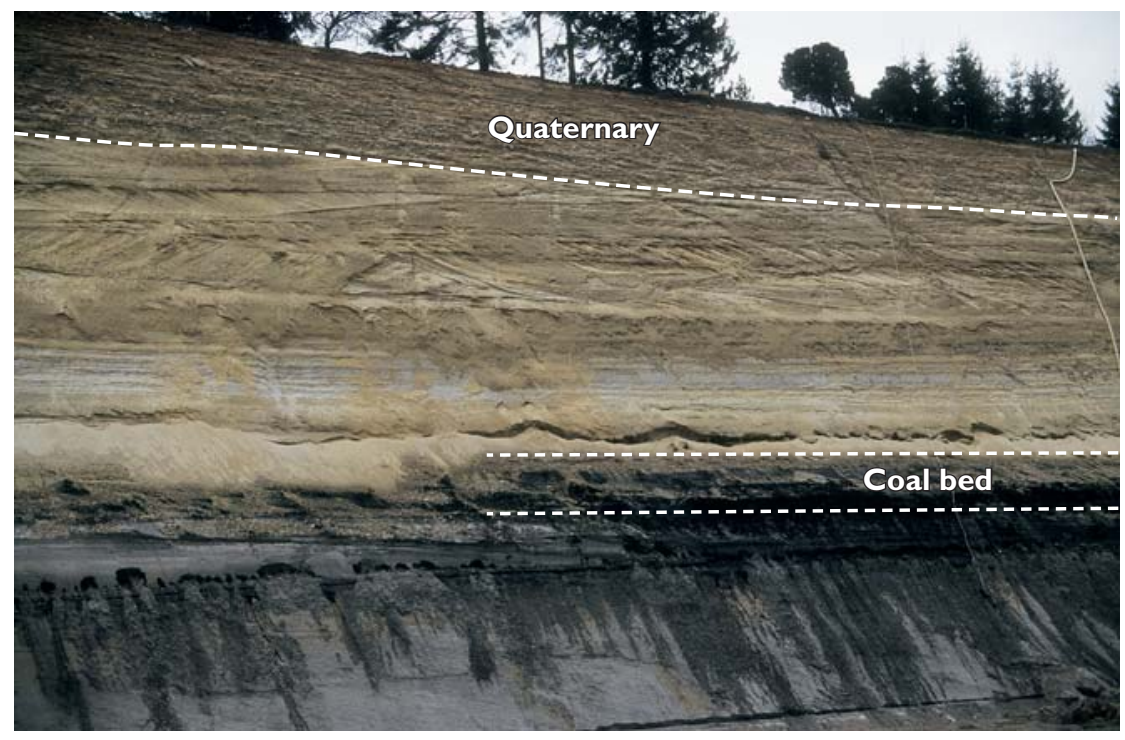

Fig. 38. Addit Member at the Addit gravel pit showing the two finingupward sand- and gravel-rich units and the intercalated coal unit. The height of the section is $40 \mathrm{~m}$.

Resen, Plate 5; Isenvad, Plate 6). Locally, a decrease in gamma-ray readings is succeeded by a gradual increase in gamma-ray values (e.g. Hammerum, Sunds, Plate 2). Here the boundary is placed at the lowest gamma-ray readings.

Distribution. The Addit Member is found in the central and northern parts of Jylland. It is especially well developed in the area south of Silkeborg, in an elongate zone striking from Resen (south-west of Viborg) to the area between Herning and Ikast (Figs 1, 10C).

Biostratigraphy. The Homotryblium spp. Dinocyst Zone of Dybkjær \& Piasecki (2010) is recorded in the Addit Member.

Geological age. The Addit Member is of Aquitanian (earliest Early Miocene) age.

Fig. 39. Cross-bedded sand and gravel of the Addit Member in the Addit gravel pit deposited as a mid-channel bar in a braided fluvial system.

The height of the section is $3 \mathrm{~m}$.

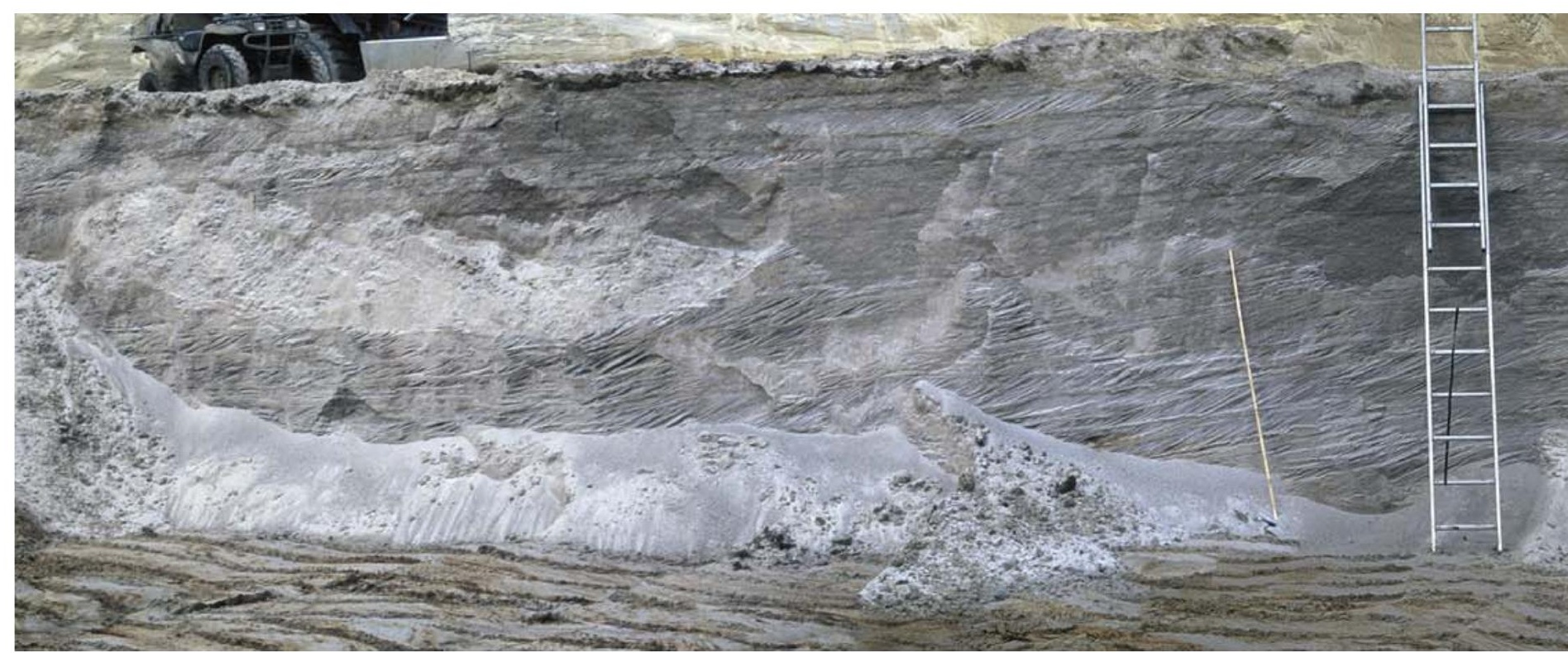




\section{Klintinghoved Formation}

redefined formation

General. The marine clay-rich deposits of the Klintinghoved Formation interdigitate towards the north-east with the more proximal sand-rich deltaic sediments of the Bastrup Formation. These formations thus alternate up-section in certain boreholes (e.g. Plates 1, 2, 6).

History. The mollusc fauna of marine clay-rich deposits at Klintinghoved was described by Sorgenfrei (1940). The deposits were defined as the Klintinghoved Formation in a later publication (Sorgenfrei 1958). The Klintinghoved Formation was included in the stratigraphy of L.B. Rasmussen (1961).

Name. After Klintinghoved cliff, Flensborg Fjord (Figs 1, 42).

Type and reference sections. Following Sorgenfrei (1958), the type section is the outcrop at Klintinghoved cliff $\left(54^{\circ} 53^{\prime} 23.15^{\prime \prime} \mathrm{N}, 9^{\circ} 49^{\prime} 43.62^{\prime \prime} \mathrm{E}\right.$; Figs 40, 42). The reference section is designated in the cored Sdr. Vium borehole (DGU no. 102.948; 5453'23.18' 'N, 949'43.94'”E) from 288 to $132 \mathrm{~m}$ (Figs 40, 41).

Thickness. At Klintinghoved, the exposed section is $3.5 \mathrm{~m}$ thick; neither base nor top of the formation is seen. In the subsurface, the formation is $10-50 \mathrm{~m}$ thick in central Jylland, thickening to over $125 \mathrm{~m}$ in the west and southwest (e.g. Sdr. Vium, Fig. 40).

Lithology. The formation consists of dark brown, silty clay with subordinate intercalated sand beds (Figs 43, 44). The sand beds are sharp based and homogenous to finely laminated; double clay layers are recognised locally. In the cored borehole at Sdr. Vium, the formation is dominated by dark brown mud with intercalated sand beds (Figs 40, $41,45)$. The sand beds typically show sharp lower boundaries, and are commonly structureless in the lower part passing upward into laminated sand.

Log characteristics. The formation is characterised by moderate to high gamma-ray values (Fig. 40). The log pattern is highly serrated, reflecting interbedded muds and sands at various levels, and shows a general decrease in gammaray response upwards.

Fossils. The Klintinghoved Formation contains a rich mollusc fauna (Sorgenfrei 1958). Shark teeth also occur and marine microfossils such as foraminifers (Laursen \& Kristoffersen 1999) and dinocysts (Dybkjær \& Rasmussen 2000; Dybkjær 2004a; Rasmussen \& Dybkjær 2005) are abundant and diverse.

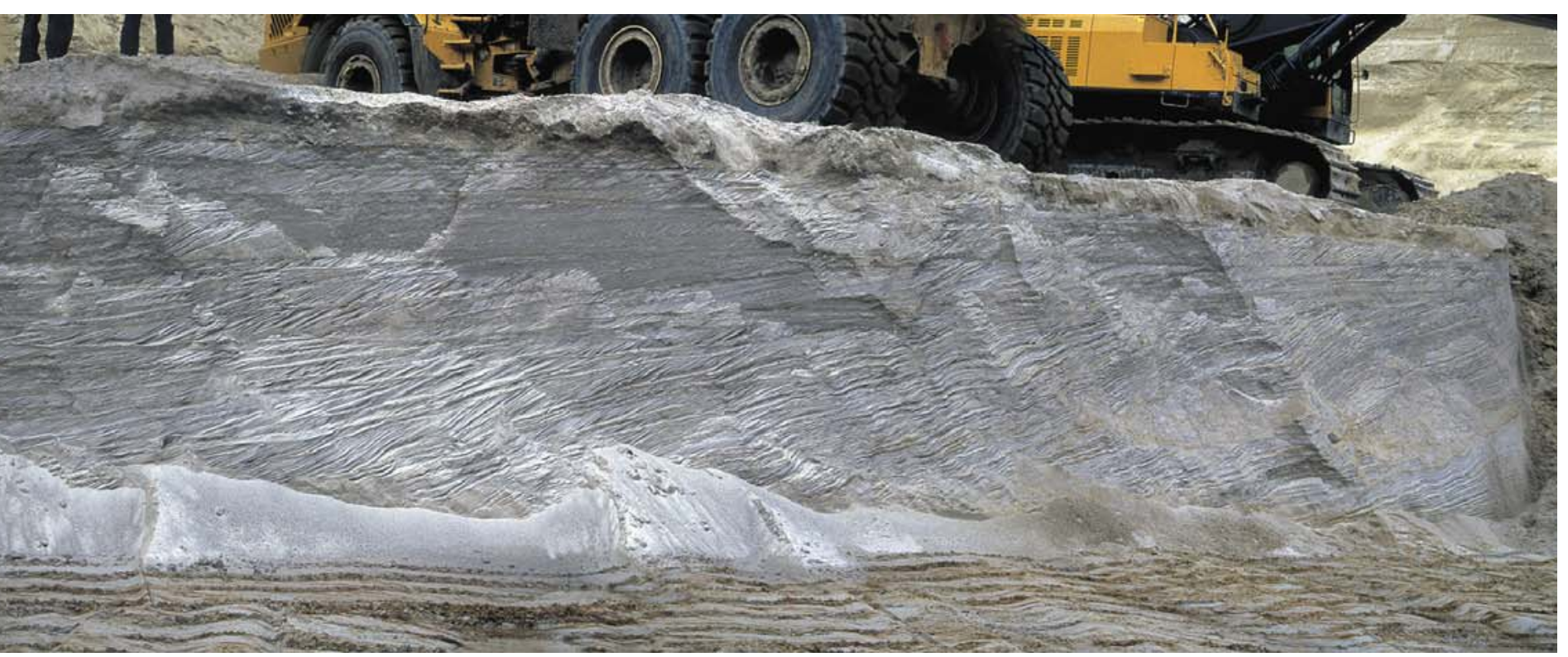




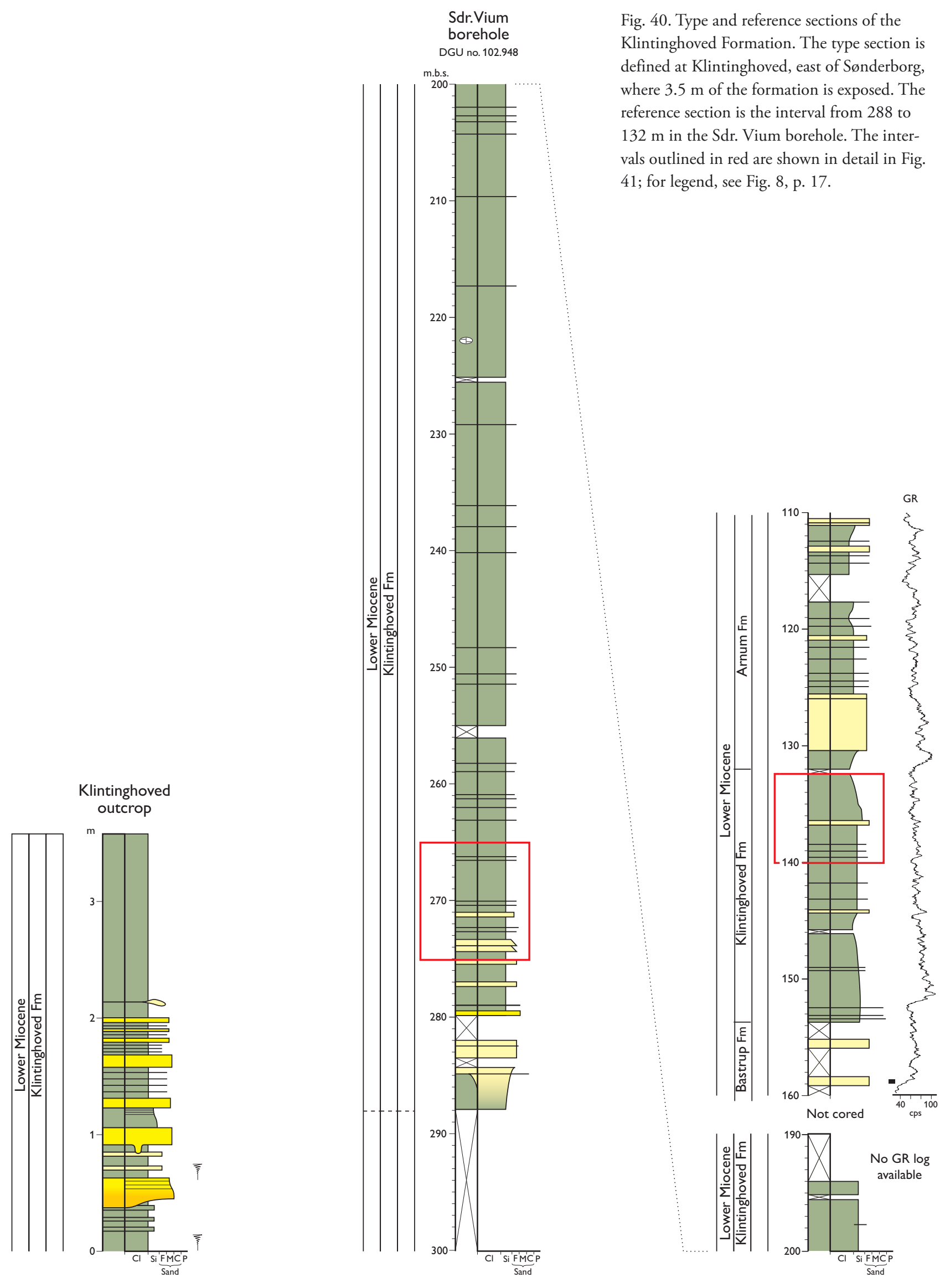




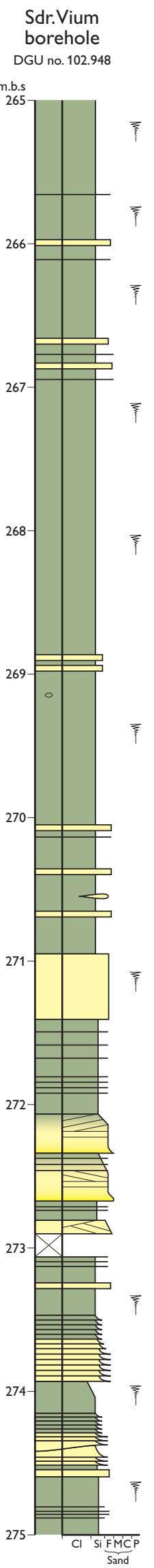

Fig. 41. Detailed sedimentological logs of representative intervals of the Klintinghoved Formation in the reference section (for location, see Fig. 40; for legend, see Fig. 8 on page 17).

Depositional environment. The Klintinghoved Formation was deposited in shelf, delta slope and lower shoreface environments. Water depths were in the order of 15 to $60 \mathrm{~m}$, but locally up to $100 \mathrm{~m}$ based on the height of clinoforms seen on seismic data. The depositional environment was strongly influenced by storms and tidal processes.

Boundaries. The lower boundary is, in the northern part, characterised by a change from sand-rich deposits of the Billund Formation to the predominantly dark brown, silty clay of the Klintinghoved Formation (e.g. Store Vorslunde, Fasterholt, Sunds and Resen boreholes, Plate 2). In the southern part where the Klintinghoved Formation overlies the Vejle Fjord Formation, the boundary is not marked by significant changes in lithology, although the Vejle Fjord Formation tends to be slightly more consolidated. On the gamma-ray log, a weak to marked shift to higher gammaray values defines the boundary, especially where the Klintinghoved Formation overlies the Billund Formation (e.g. Rødding, Almstok, Store Vorslunde, Fasterholt, Sunds and Resen boreholes, Plate 2). At outcrop, the lower boundary is often erosional and overlain by a gravel lag, as seen at Rønshoved and Børup (Rasmussen \& Dybkjær 2005); the gravel lag commonly contains clasts up to $4 \mathrm{~cm}$ in diameter.

The upper boundary is either sharp, exemplified by the Bastrup borehole (Fig. 52; Plate 8), or gradational as in the Almstok borehole (Fig. 52; Plate 2). In the Bastrup borehole, the upper boundary is placed where grey mud is sharply overlain by grey, medium-grained sand. In boreholes where a more gradational development occurs, the boundary is marked by a change from alternating beds of sand and mud to a clean sand unit at least $5 \mathrm{~m}$ thick and comprising at least $75 \%$ sand. On the gamma-ray log, the 

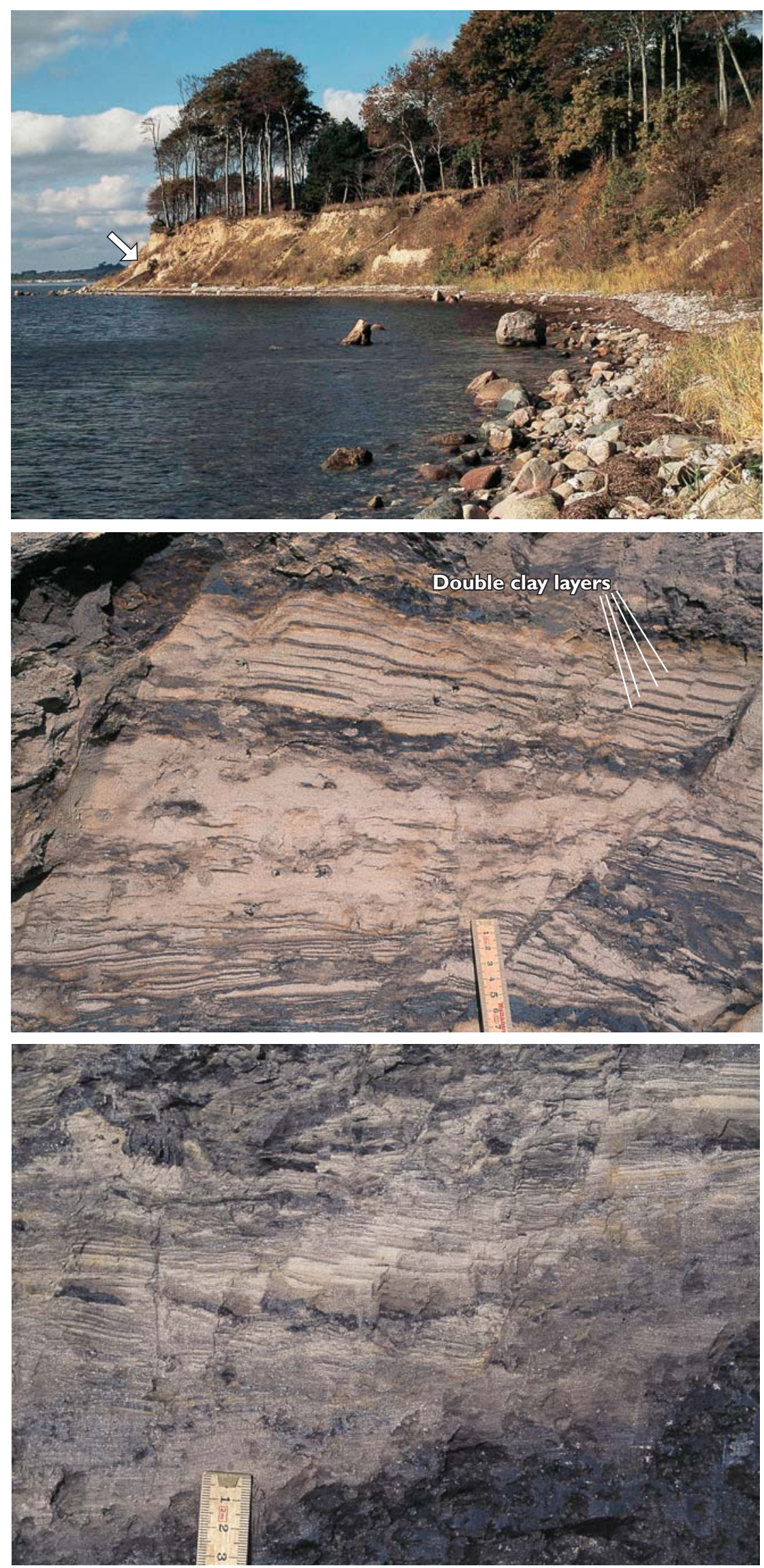

Fig. 42. The Klintinghoved cliff, viewed from the east (cliff is $c .10 \mathrm{~m}$ high). The location of the type section of the Klintinghoved Formation is arrowed.

Fig. 43. Alternating clay and bioturbated and laminated sand of the Klintinghoved Formation at the type locality. Note the double clay layers in the sand indicating tidal influence on deposition.

Fig. 44. Interlaminated, dark brown clayey silt and thin, fine-grained sand of the Klintinghoved Formation at the type locality. 


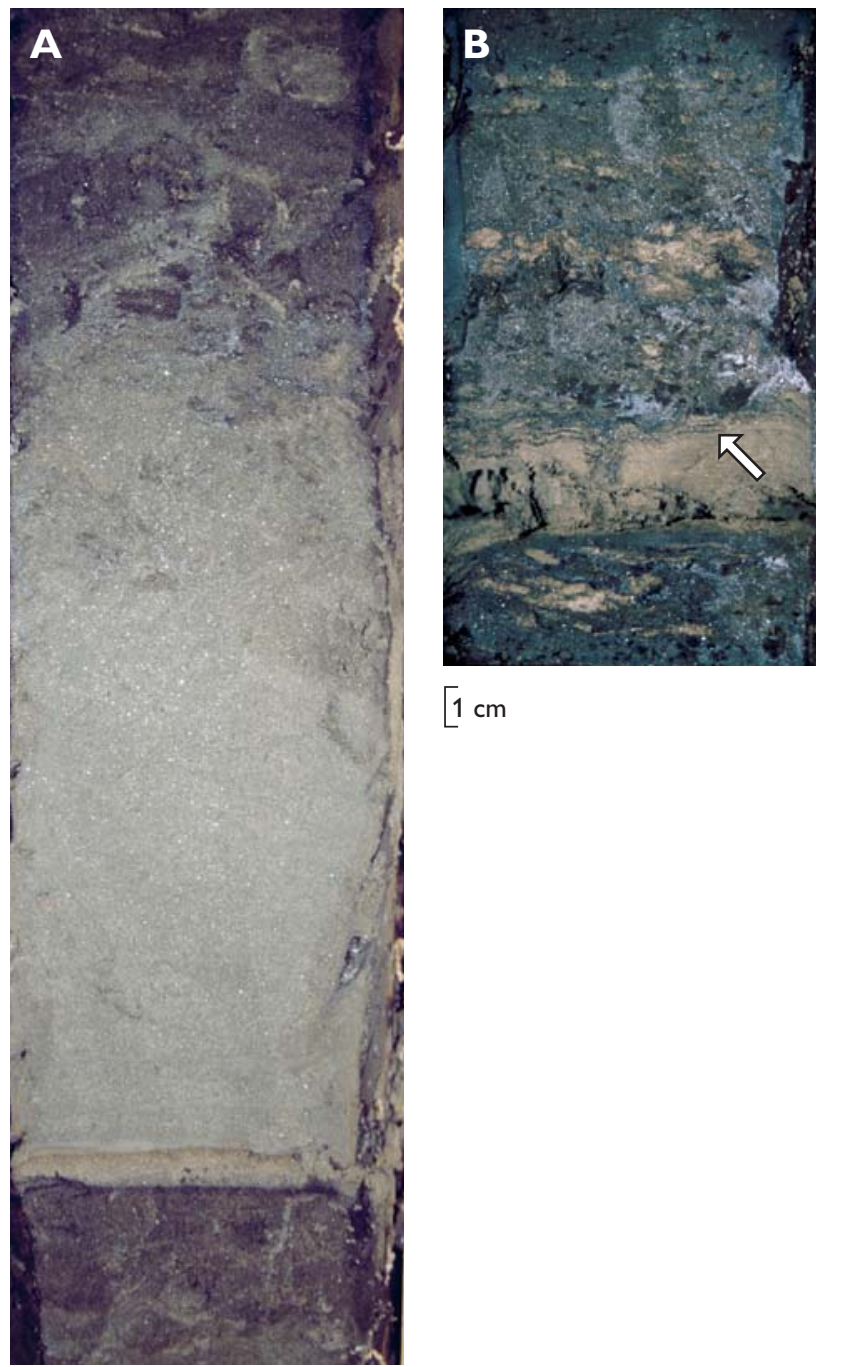

Fig. 45. Core sections from the Sdr. Vium borehole, illustrating interbedded, dark brown silty clays and sharp-based sands of the Klintinghoved Formation. A: 272.70 m (base of illustrated section); B: $250.45 \mathrm{~m}$ (base). The sand beds are normally graded and homogenous to weakly laminated in the lower part. Note the double clay layers $(B$, arrow) indicating tidal influence on sedimentation. boundary is generally characterised by a minor decrease in gamma-ray values followed by a consistent decrease in values upwards, as seen in the Almstok borehole (Fig. 52; Plate 2) and in the Holstebro and Klosterhede boreholes (Plate 4). In the Bastrup borehole, the upper boundary is characterised by a distinct decrease in gamma-ray values. In western Jylland where Klintinghoved Formation is overlain by the Arnum Formation (e.g. Kvong, Sdr. Vium boreholes, Plate 4), the boundary is placed at a distinct increase in gamma-ray readings separating coarsening-upward units of the Klintinghoved and Arnum Formations.

Distribution. The Klintinghoved Formation is distributed in the northern part of central Jylland and in western and southern Jylland (Fig. 10D).

Biostratigraphy. The Thalassiphora pelagica and Sumatradinium hamulatum Dinocyst Zones of Dybkjær \& Piasecki (2010) are recognised in the Klintinghoved Formation.

Geological age. The Klintinghoved Formation is of late Aquitanian to early Burdigalian (Early Miocene) age.

Subdivision. The Klintinghoved Formation includes the new Kolding Fjord Member. 
History. Sand and organic-rich clayey sediments exposed at Lillebælt were studied by Radwanski et al. (1975), E.S. Rasmussen (1995) and Friis et al. (1998). In these studies, the sediments were referred tentatively to the Vejle Fjord Formation of previous usage. However, a biostratigraphic study by Dybkjær \& Rasmussen (2000) revealed that the sediments were significantly younger than the Vejle Fjord Formation (as recognised here) and equivalent in age to the Klintinghoved Formation (L.B. Rasmussen 1961).

Name. The Kolding Fjord Member crops out at a number of localities along Lillebælt and Kolding Fjord. It is named after Kolding Fjord, where the type locality of Rønshoved is situated.

Type and reference sections. The type section is the exposure at Rønshoved on the southern side of Kolding Fjord $\left(55^{\circ} 29^{\prime} 26.90^{\prime \prime} \mathrm{N}, 9^{\circ} 38^{\prime} 36.10^{\prime \prime} \mathrm{E}\right.$; Figs 1, 46). Other localities where the member is exposed are Hagenør, Børup, Galsklint and Fænø in the Lillebælt and Kolding Fjord area (Fig. 1). A minor outcrop is also recognised at Gyldendal, Limfjorden. The reference section is the outcrop at Hagenør (Figs 1, 47).

Thickness. The Kolding Fjord Member is $11 \mathrm{~m}$ thick at Rønshoved and c. $8 \mathrm{~m}$ at Hagenør (Figs 46, 47). Although rarely exceeding $10 \mathrm{~m}$, developments up to $20 \mathrm{~m}$ thick are recognised locally (e.g. Vonsild and Vind boreholes, Plates $1,8)$.

Lithology. The member is composed of white to yellow, fine- to medium-grained sand with a few thin, brown clay layers. At the type section, the basal unit is a gravel layer c. $10 \mathrm{~cm}$ thick that contains clasts up to $4 \mathrm{~cm}$ in diameter. The clasts consist of almost pure quartz and quartzitic sandstone. The succeeding sandy part of the member in the type section is dominated by hummocky and swaley crossstratified silt and fine-grained sand (Figs 46, 48). The more clayey part is dominated by heterolithic mud which shows hummocky cross-stratification and clear rhythmicity i.e. double clay layers and alternating sand- and mud-rich units. Layers up to $2 \mathrm{~m}$ thick of dark brown, organic-rich, clayey silt may be intercalated in the sand (Figs 49, 50). Homo-

Fig. 46. Type section of the Kolding Fjord Member at Rønshoved, east of Kolding; for legend, see Fig. 8, p. 17.
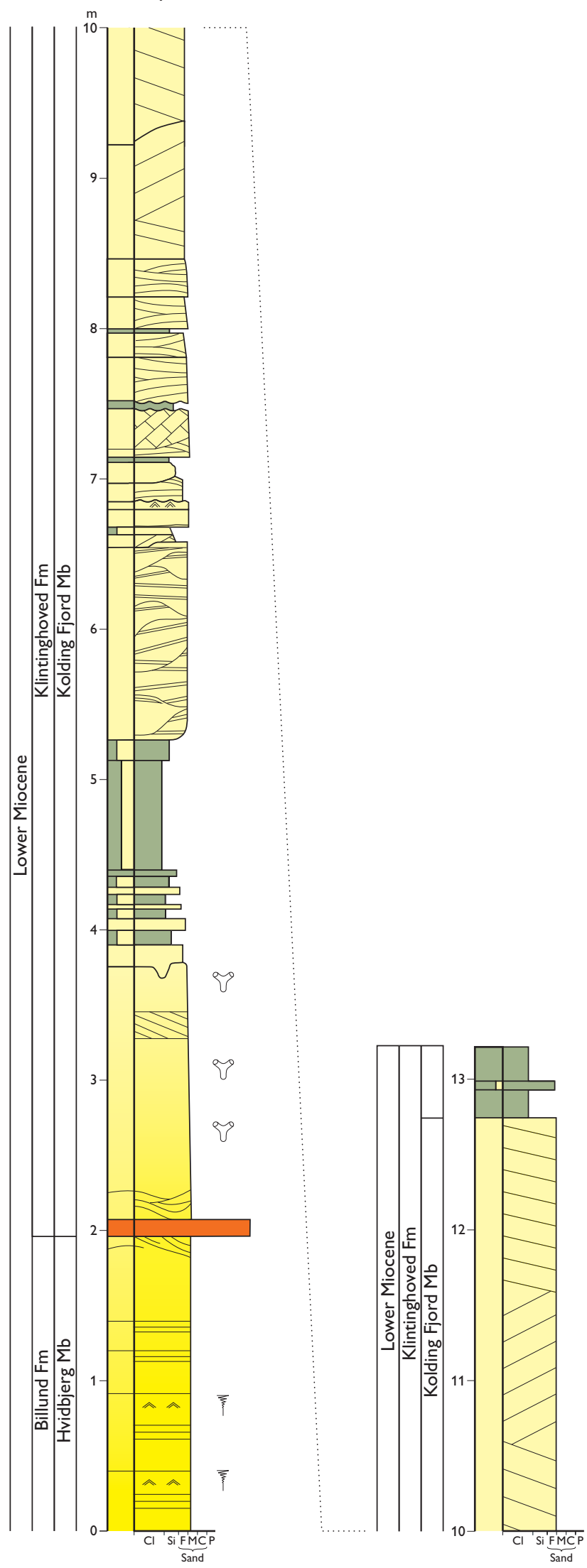


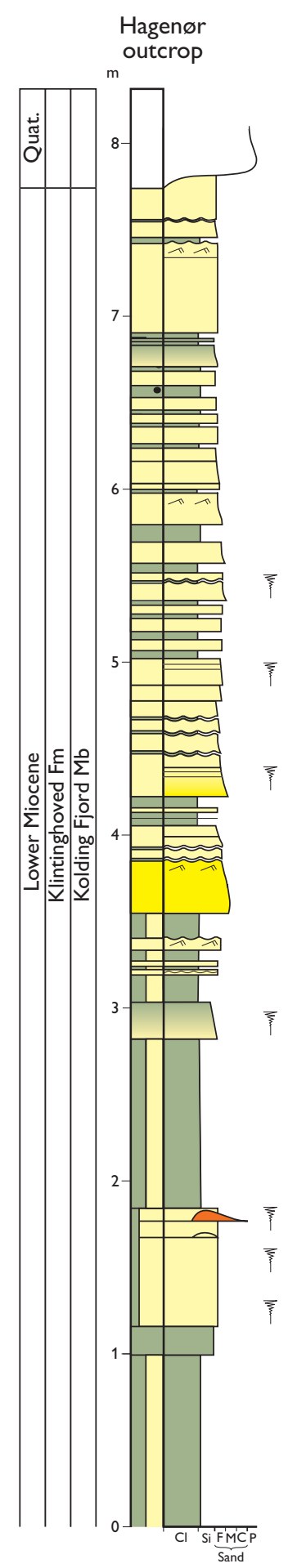

Fig. 47. Reference section of the Kolding Fjord Member at Hagenør; for legend, see Fig. 8, p. 17. Quat.: Quaternary.

geneous sand beds capped by wave-ripples are also common on top of lagoonal deposits (Fig. 51); wave-ripple crests are oriented north-west-south-east. Trace fossils, including Macaronichnus isp., Ophiomorpha nodosa and echinoid burrows, are common in the Kolding Fjord Member (Radwanski et al. 1975).

Log characteristics. The member is characterised by low to moderate gamma-ray values. The log pattern is serrated; high gamma-ray values are registered where lagoonal, clay-rich deposits dominate.

Fossils. The Kolding Fjord Member contains a dinocyst assemblage of variable richness (Dybkjær \& Rasmussen 2000; Rasmussen \& Dybkjær 2005).

Depositional environment. Deposition took place on a stormdominated coast in a lower and upper shoreface environment (Friis et al. 1998; Rasmussen \& Dybkjær 2005). The fine-grained, heterolithic part was deposited in a lagoonal environment with some tidal influence. The upper part of the member was deposited as washover fans on the back-barrier flat during the final degradation of the barrier complex.

Boundaries. In the type section, the lower boundary is erosional and, as in other exposures (e.g. Børup, Galsklint) and borehole sections (e.g. Stakroge, Plate 3), is defined by a distinct change from the sandy deposits of the Billund Formation to gravel-dominated layers of the lowermost Kolding Fjord Member. In such cases, the gamma-ray log shows a marked decrease in values at the boundary (Plate 3). In the Vonsild borehole, however, located near the type and reference sections, the lower boundary is recognised by a prominent increase in gamma-ray readings, due to the presence of fine-grained, lagoonal sediments in the lower part of the member (Plates 1,8). It is acknowledged that identification of this boundary may be difficult on the gamma-ray log where shoreface sands occur both beneath and above the boundary and the transgressive lag is thin.

The upper boundary is characterised by a change from the sand-dominated succession of the Kolding Fjord Member to dark brown, clayey silts of the Klintinghoved Formation. The gamma-ray log shows a distinct increase in gamma-ray values.

Distribution. The member is recognised in east Jylland and south-west of Holstebro in west Jylland (Fig. 10D).

Biostratigraphy. The Thalassiphora pelagica and Sumatradinium hamulatum Dinocyst Zones of Dybkjær \& Piasecki (2010) occur in the Kolding Fjord Member.

Geological age. The Kolding Fjord Member is of late Aquitanian to early Burdigalian (Early Miocene) age. 


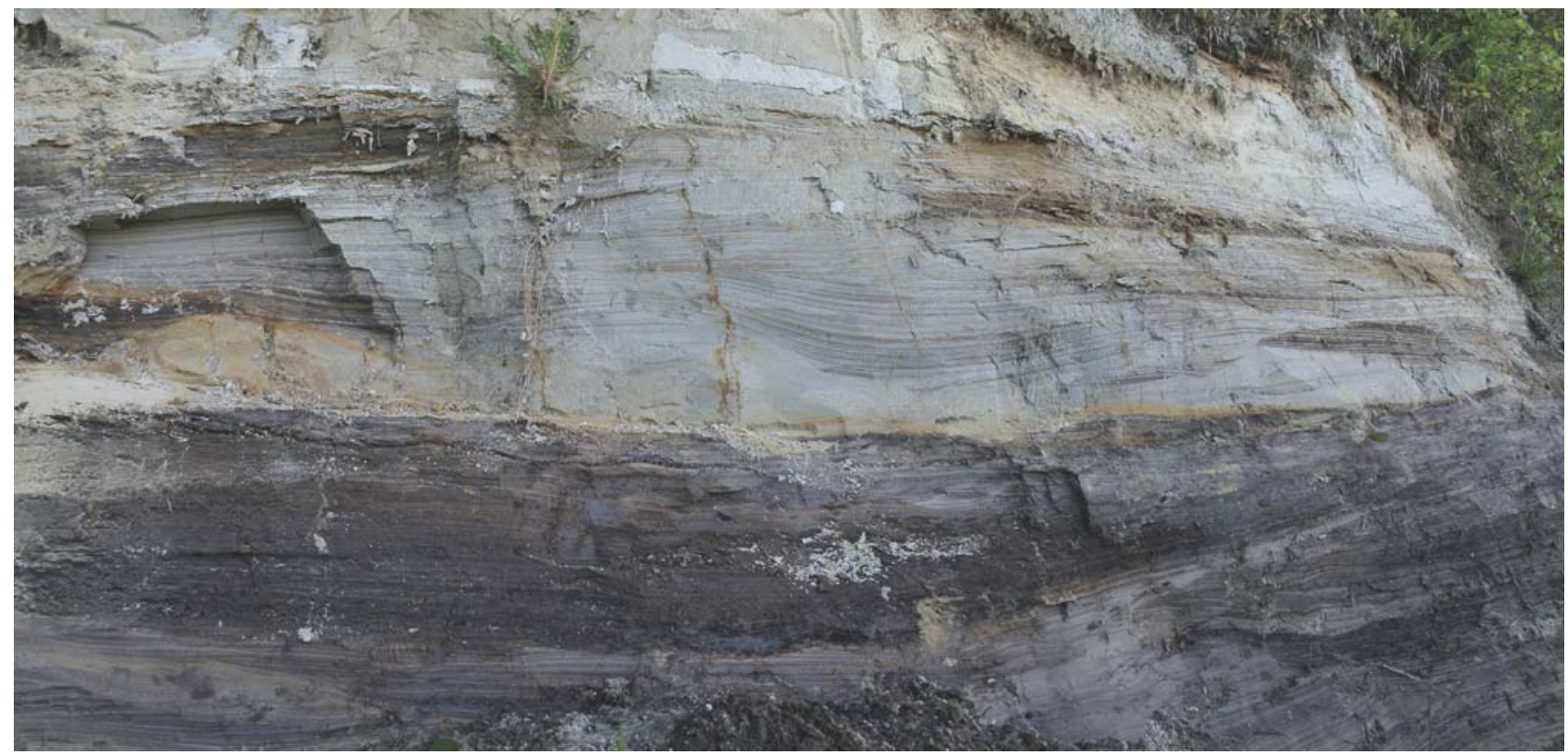

Fig. 48. Heterolithic deposits of the Kolding Fjord Member sharply overlain (at $5.3 \mathrm{~m}$ in Fig. 46) by hummocky cross-stratified sand at Rønshoved in the type section. The heterolithic succession is characterised by alternating hummocky cross-stratified sand and sandy clay and various types of ripple-laminated sand. About $3 \mathrm{~m}$ of the section is shown.

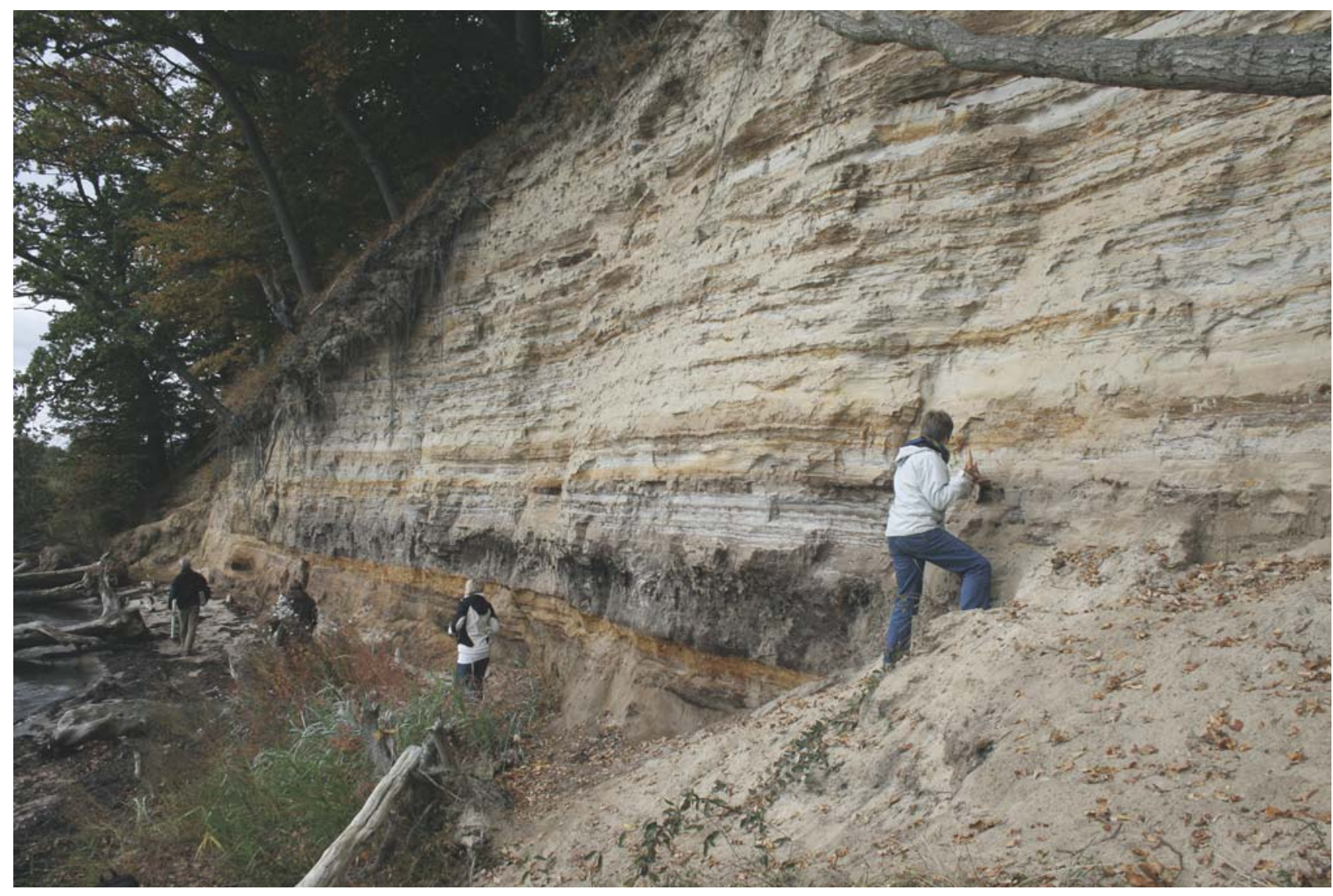

Fig. 49. Exposure of the Kolding Fjord Member in the reference section at Hagenør. The lower part of the Hagenør outcrop is characterised by two organic-rich, clayey silt deposits separated by bioturbated sand (see Fig. 47). The upper part of the exposure is dominated by alternating sand and clay layers; the sand beds are typically sharp based, homogenous to weakly laminated in the lower part and capped by waveor current-ripples. 
Fig. 50. Close-up of lagoonal facies in the Kolding Fjord Member at Hagenør. The light brown deposits that are capped by sand ripples and sandwiched between dark lagoonal clays contain marine palynomorphs and represent a short marine incursion; the strike of the ripple crests is NW-SE. The illustrated section is $c .2 \mathrm{~m}$ high.

Fig. 51. Close-up of the alternating sand and clay layers of the Kolding Fjord Member exposed in the upper part of the Hagenør reference section. Spade handle for scale.
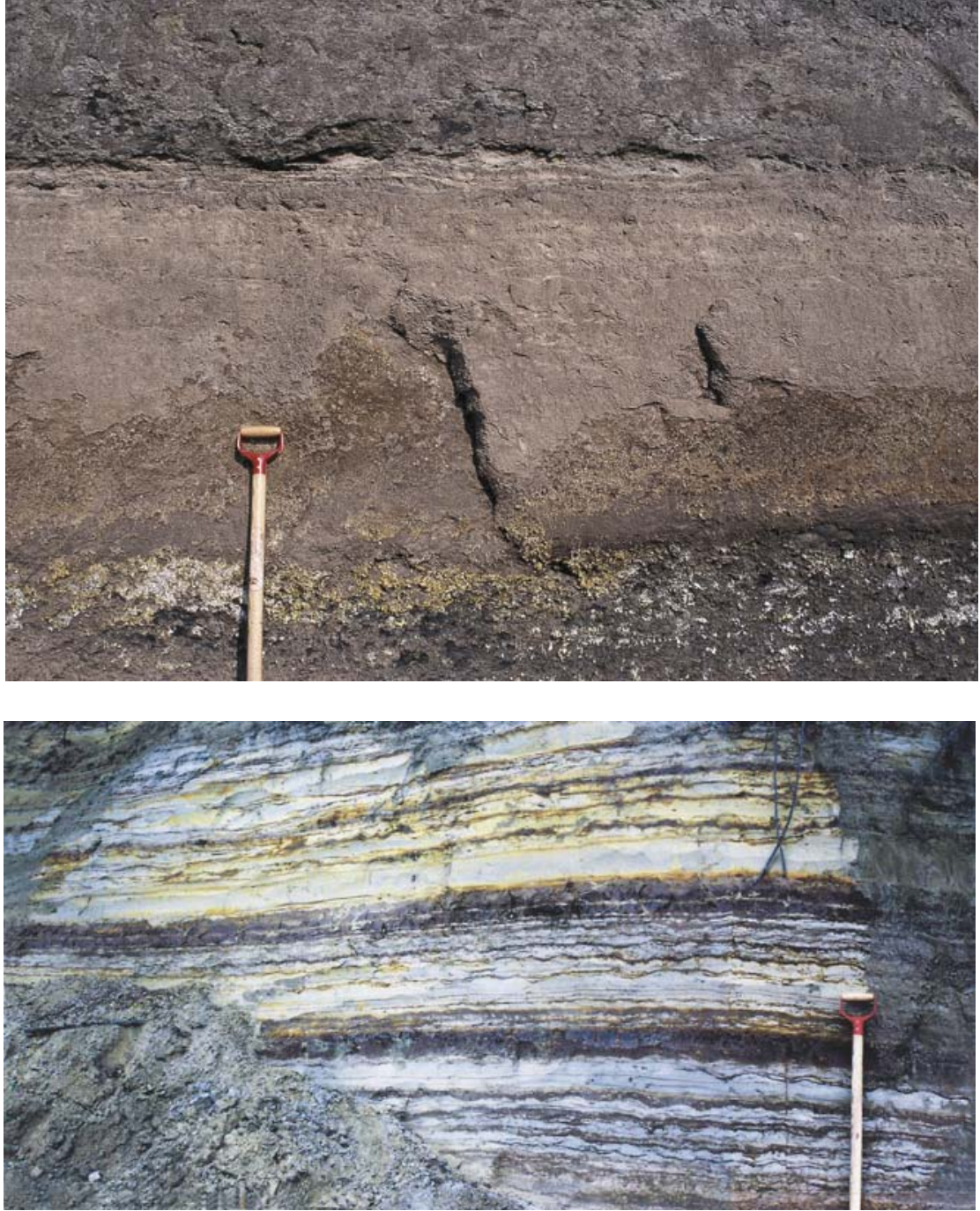

\section{Bastrup Formation}

new formation

General. The new Bastrup Formation is recognised primarily in the subsurface. This fluvio-deltaic, sand-dominated formation interdigitates in a complex manner with the more distal, marine, mud-rich Klintinghoved Formation. These formations thus alternate up-section in certain boreholes (e.g. Plates 1, 2, 6).

Name. After Bastrup village, south-west of Kolding (Fig. 1).

Type and reference sections. The type section is the interval from 108 to $84 \mathrm{~m}(110-84 \mathrm{~m} \mathrm{MD})$ in the Bastrup borehole (DGU no. $133.1298 ; 55^{\circ} 24^{\prime} 21.58^{\prime \prime} \mathrm{N}, 9^{\circ} 14^{\prime} 47.40^{\prime \prime} \mathrm{E}$; Fig. 52). The reference section is the interval from 160 to $111 \mathrm{~m}(160-111 \mathrm{~m} \mathrm{MD})$ in the borehole at Almstok (DGU no. 114.1858; Fig. 52).
Thickness. The thickness of the Bastrup Formation is 24 $\mathrm{m}$ in the type section, but the formation is commonly $c$. $50 \mathrm{~m}$ thick (see reference section, Fig. 52 and Plates 2, 3). A maximum thickness of $100 \mathrm{~m}$ was penetrated in the borehole at Løgumkloster (Plate 3).

Lithology. The Bastrup Formation consists predominantly of grey, medium- to coarse-grained sand with intercalated gravel layers; the diameter of gravel clasts rarely exceeds 2 $\mathrm{cm}$. Petrologically, the sand is dominated by quartz and quartzite lithic grains with minor content of mica and heavy minerals. In a few boreholes, however, a high concentration of mica has been recorded (e.g. Estrup). Dark brown, organic-rich, silty clay is locally present. The formation is characterised by both coarsening-upward and fining-upward depositional patterns. The upper part of the formation is commonly characterised by a $15-30 \mathrm{~m}$ thick fining-upward succession consisting of coarse-grained to finegrained sand. In the north, gravel commonly forms the 
base of the fining-upward units. Clay-rich sediments with subordinate intercalations of coal are often sandwiched between sand-rich units.

Log characteristics. The formation is characterised by low gamma-ray values (Fig. 52). The log pattern is serrated and shows both decreasing- and increasing-upward trends through the succession. The decreasing trend is associated with delta progradation and the increasing-upward trend is associated with channel-fill deposits (i.e. point bars) which are common in the upper levels of the formation, and can locally be demonstrated on seismic data (E.S. Rasmussen et al. 2007).

Fossils. A sparse foraminifer assemblage occurs in the distal part of the Bastrup Formation (Laursen \& Kristoffersen 1999). The dinocyst flora is variable overall, being rich at some levels and very sparse/impoverished at other levels (Dybkjær 2004a; Dybkjær \& Piasecki 2010).

Depositional environment. Deposition took place in deltaic and fluvial environments. Well developed point bars and fluvial channels are common in the upper part (E.S. Rasmussen et al. 2007; E.S. Rasmussen 2009b). The intercalated mud represents floodplain deposition.

Boundaries. The lower boundary is either sharp, for example in the type section of the Bastrup borehole or gradational as in the Almstok reference section (Fig. 52). In the type section, the lower boundary is placed where grey mud is sharply overlain by grey, medium-grained sand; on the gamma-ray log, this lower boundary is defined at a marked decrease in gamma-ray values. A gravel layer is commonly present at the base of the Bastrup Formation. In gradational sections showing interbedded sands and muds, becoming sandier upwards, the boundary is defined at the base of the first significant sand interval (at least $5 \mathrm{~m}$ thick) in which the sand to mud ratio is greater than $75 \%$. In such gradational sections, the log response reflects the transitional nature of the boundary, showing a minor decrease in gamma-ray values followed by a consistent overall decrease upwards (e.g. the Almstok borehole, Fig. 52).

The upper boundary is defined by a sharp transition from grey and white sand of the Bastrup Formation to dark brown, silty clay of the Arnum Formation. In central Jylland, the Arnum Formation is developed as a grey to white silt, which rests with a sharp boundary on the sand-rich Bastrup Formation. On the gamma-ray log, this upper boundary is typically identified by a prominent shift to higher values.

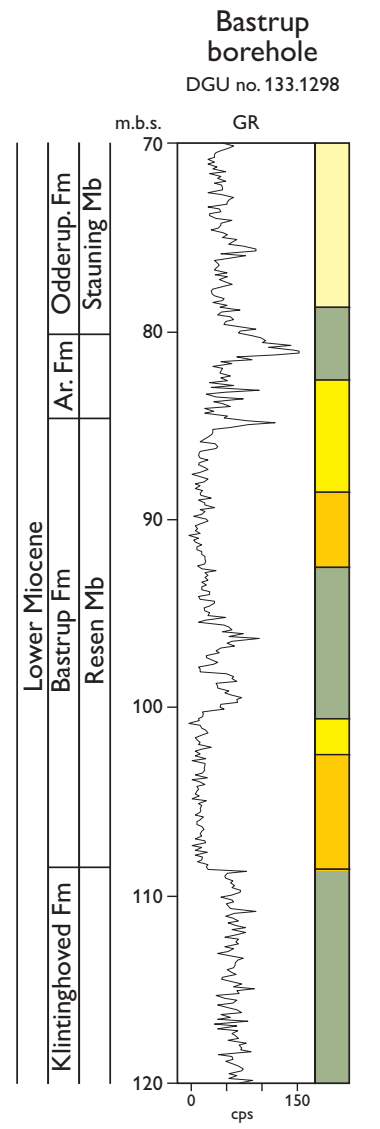

Fig. 52. Type and reference sections of the Bastrup Formation. The type section is from 108 to $84 \mathrm{~m}$ in the Bastrup borehole. The reference section is from 160 to $111 \mathrm{~m}$ in the Almstok borehole; for legend, see Fig. 8 on page 17. Ar.: Arnum.

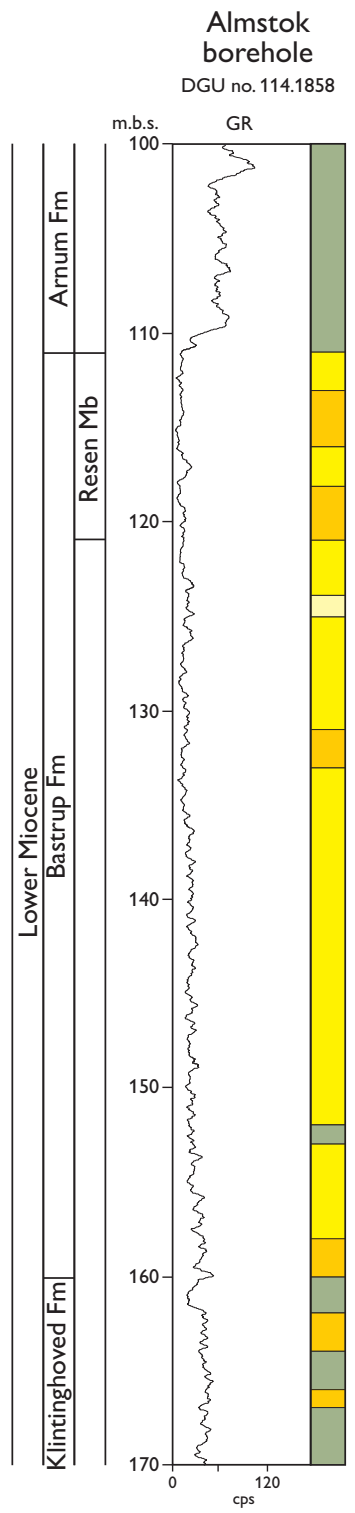

Distribution. The formation is present in southern and central Jylland. Towards the north-east, the formation is truncated and it pinches out towards the south-west (Fig. 10E).

Biostratigraphy. The Sumatradinium hamulatum and Cordosphaeridium cantharellus Dinocyst Zones of Dybkjær \& Piasecki (2010) occur in the Bastrup Formation.

Geological age. The Bastrup Formation is of early Burdigalian (Early Miocene) age.

Subdivision. The Bastrup Formation includes the new Resen Member. 


\section{Resen Member}

new member

General. This member is recognised widely in the Bastrup Formation, representing fluvial-dominated facies that commonly are inferred to be incised into the undifferentiated Bastrup Formation deltaic facies. It is mainly recognised in the subsurface, but coal was formerly mined in a pit near Resen, south of Skive (Fig. 1).

Name. After the village of Resen, south of Skive, where a brown-coal pit was mined (Fig. 1).

Type and reference sections. The type section is the composite interval from 124 to $112 \mathrm{~m}$ and from 97 to $70 \mathrm{~m}$ (125-113 m MD, 97-71 m MD) in the borehole at Hammerum, east of Herning (DGU no. 85. 2429; $56^{\circ} 07^{\prime} 55.45^{\prime \prime} \mathrm{N}, 9^{\circ} 05^{\prime} 33.52^{\prime \prime} \mathrm{E}$; Figs 1,53$)$. The reference section is the interval from 104 to $67 \mathrm{~m}(105-67 \mathrm{~m} \mathrm{MD})$ in the Egtved borehole, south-west of Vejle (DGU no. 124.1159; Figs 1, 53).

Thickness. The member is $39 \mathrm{~m}$ thick in the type section (Fig. 53) and is typically in the range $10-40 \mathrm{~m}$ thick (Plates $2,3,6,7)$.

Lithology. The member consists of grey, medium- to coarsegrained sand with intercalated gravel layers. Dark brown, organic-rich, silty clay with some coal is present locally. The member is typically characterised by $10-30 \mathrm{~m}$ thick fining-upward successions; a number of boreholes show stacked, fining-upward cycles that may be separated by intervals referred to the Bastrup Formation (undifferentiated).

Log characteristics. The member is characterised by low gamma-ray readings. The log pattern is serrated and, where simply developed (e.g. Billund, Plate 2), shows an increasing trend upwards, reflecting the origin of these sand-rich units as channel fill deposits. In some boreholes, such channel sands are separated by finer-grained deposits showing moderate-high gamma-ray values (Fig. 53).

Fossils. The dinocyst flora is variable overall, being rich at some levels and very sparse/impoverished at other levels (Dybkjær 2004a; Dybkjær \& Piasecki 2010).

Depositional environment. Deposition took place in fluvial environments, and well-developed point bars and fluvial channels are common (E.S. Rasmussen et al. 2007; E.S. Rasmussen 2009b). The intercalated mud represents flood-

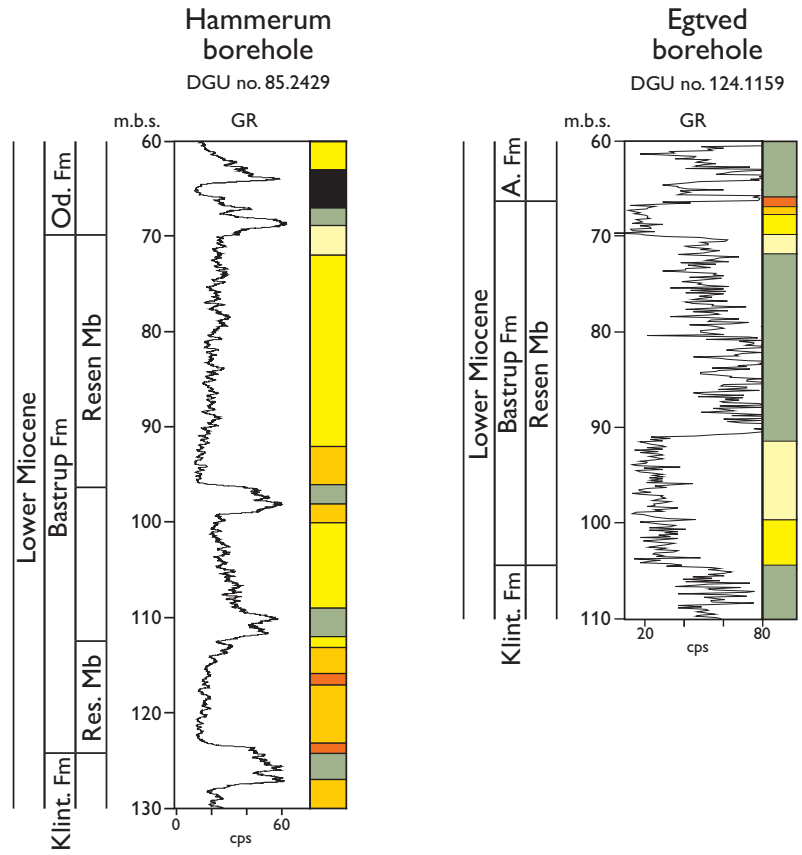

Fig. 53. Type and reference sections of the Resen Member. The composite section (124-112 m, 97-70 m) in the Hammerum borehole is designated as the type section. The reference section is the interval from 104 to $67 \mathrm{~m}$ in the Egtved borehole; for legend, see Fig. 8, p. 17. A.: Arnum. Klint.: Klintinghoved. Od.: Odderup. Res.: Resen.

plain deposition and some marine influence has also been recognised, especially in the southern part. The most extensive coal formation was within freshwater lakes and mires developed in the rim synclines around salt diapirs, e.g. the Sevel and Mønsted salt structures south of Skive (Japsen \& Langtofte 1991).

Boundaries. The Resen Member is bounded both by sandrich units (e.g. Bastrup Formation beneath, Vandel Member above) and by mud-rich units (Klintinghoved Formation beneath, Arnum Formation above). Where succeeding the Klintinghoved Formation, the boundary is sharp and placed where dark brown, clayey silts of the Klintinghoved Formation are sharply overlain by grey, medium- to coarsegrained sands, locally with a basal gravel layer. On the gamma-ray log, this relationship is recorded by an abrupt shift to lower values (Fig. 53). In sections where the Resen Member succeeds the undifferentiated Bastrup Formation, the boundary is defined at the base of coarser sand/gravel deposits at a shift from decreasing-upward gamma-ray values (Bastrup Formation) to increasing-upward gamma-ray values (Resen Member channel sands). 
The upper boundary is typically defined by a sharp transition from grey and white sands of the Resen Member to dark brown, silty clay of the Arnum Formation; on the gamma-ray log this is reflected by an abrupt increase in values. In central Jylland, the upper boundary is characterised by a sharp change from grey and white sand to grey and white silt of the Vandel Member. On the gamma-ray $\log$, this facies transition is reflected by an increase in gamma-ray values that continues up through the Vandel Member.

Distribution. The member is present in southern and central Jylland (Fig. 10E; Plates 1, 2, 6). Towards the northeast, the member is truncated and it pinches out towards the south-west.

Biostratigraphy. The Sumatradinium hamulatum and Cordosphaeridium cantharellus Dinocyst Zones of Dybkjær \& Piasecki (2010) occur in the Resen Member.

Geological age. The Resen Member is of early Burdigalian (Early Miocene) age.

\section{Arnum Formation}

revised formation

General. The marine clay-dominated Arnum Formation is only recognised in the subsurface where it shows complex interdigitation with the nearshore sand-rich Odderup Formation. These two formations thus altenate up-section in some boreholes (Plates 1-9).

History. The Arnum Formation was defined by Sorgenfrei (1958) to encompass the dark micaceous marine clays occurring stratigraphically above the Ribe Formation (of previous usage).

Name. After Arnum village in southern Jylland (Fig. 1).

Type and reference sections. The Arnum Formation was penetrated in two boreholes at Arnum (DGU no.150.13, DGU no. 150.25 b; both at $55^{\circ} 14^{\prime} 48.07^{\prime \prime} \mathrm{N}, 8^{\circ} 58^{\prime} 18.48^{\prime \prime} \mathrm{E}$ ) from 107 to $40 \mathrm{~m}$ and from 107.5 to $40 \mathrm{~m}$ respectively (Sorgenfrei 1958); together these sections form the type section. The composite interval $132-111 \mathrm{~m}$ and $98-51 \mathrm{~m}$ in the cored borehole, Sdr. Vium (DGU no. 102.948) is designated as the reference section (Fig. 54). A secondary reference section is defined as the interval from 55 to $37 \mathrm{~m}$
(56-39 m MD) in the Store Vorslunde borehole (DGU no. 104.2325; Fig. 55).

Thickness. The formation is $c .93 \mathrm{~m}$ thick in the type borehole (Sorgenfrei 1958). The formation is commonly only a few tens of metres thick in the north-east of the area but thickens west and south (Plates 4, 7, 9); about 130-150 $\mathrm{m}$ were encountered in the Borg-1 and Rømø boreholes and nearly $200 \mathrm{~m}$ in the Forumlund borehole (Plate 4).

Lithology. The Arnum Formation consists of dark brown, silty clay with occasional shell beds. Thin laminated, finegrained sand beds are common. The sand beds commonly display a sharp lower boundary succeeded by laminated and low-angle cross-bedded sand capped by wave laminated sand. Micro-hummocky cross-stratification is common. Some of the wave-rippled sand beds have sharp erosive upper boundaries overlain by mud (Fig. 56A-C). Thin sand beds and silt layers may have a high content of heavy minerals; glaucony is present and locally forms discrete lamina (Fig. 56D).

Log characteristics. The formation is characterised by moderate-high gamma-ray values (Figs 54, 55). The log pattern is serrated (reflecting subordinate interbedded sands) and commonly shows an overall decreasing trend upwards. Discrete gamma-ray peaks may be related to silt and sand beds rich in heavy minerals.

Fossils. The Arnum Formation contains a rich assemblage of marine molluscs (Sorgenfrei 1958; L.B. Rasmussen 1961). Rich foraminifer and dinocyst assemblages also occur in this formation (Laursen \& Kristoffersen 1999; Dybkjær \& Piasecki 2010).

Depositional environment. The Arnum Formation was deposited in a fully marine shelf environment. The water depth is unknown, but the concentration of heavy minerals and the presence of scours and wave-rippled sand may indicate rather shallow water with frequent reworking and sorting of sediments.

Boundaries. The Arnum Formation is typically bounded by sand-rich formations, the Bastrup Formation or Vandel Member beneath and the Odderup Formation, both beneath and above. In the former case, the lower boundary is defined by a sharp transition from grey and white sand of the Bastrup Formation to dark brown, silty clay of the Arnum Formation, recorded on the gamma-ray log as an abrupt increase in values. In central Jylland, the lower boundary is defined at the change from grey and white sand to grey 


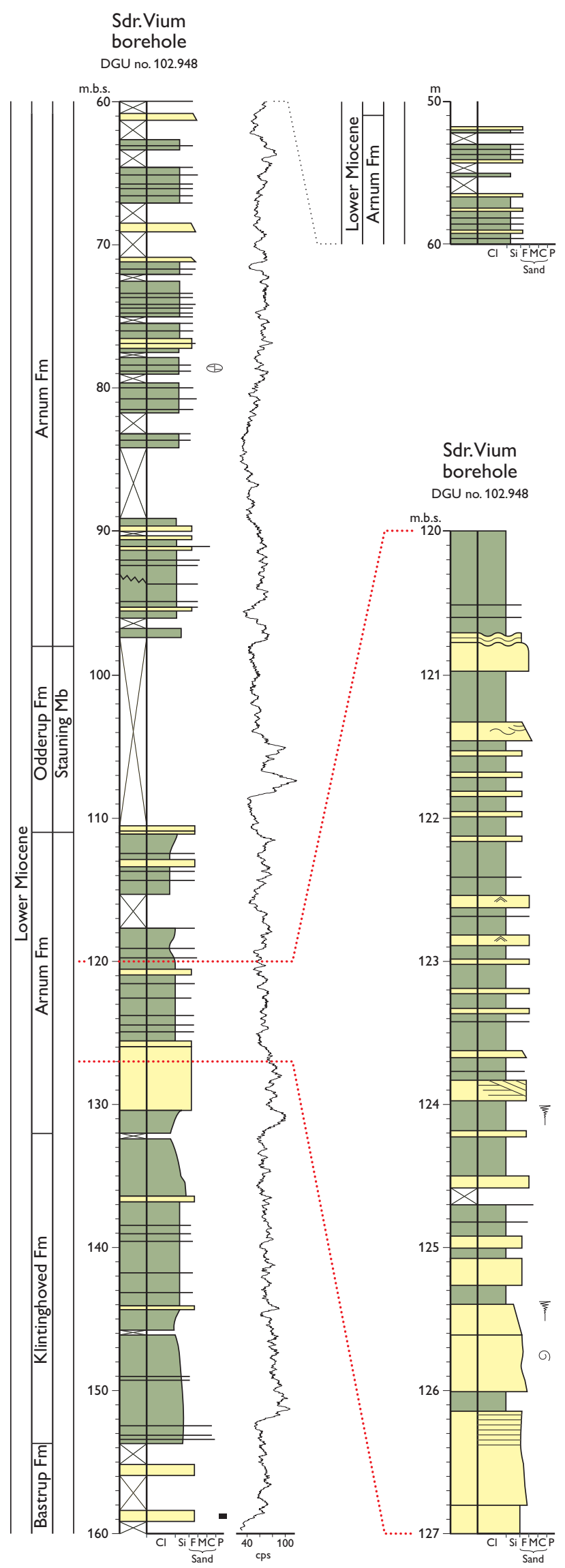

Fig. 54. The primary reference section of the Arnum Formation is the composite interval $(132-111 \mathrm{~m}, 98-51 \mathrm{~m})$ in the cored Sdr. Vium borehole; for legend, see Fig. 8, p. 17.

and white silt of the Vandel Member. In western and southern sections, the Bastrup Formation is absent and the clayrich Arnum Formation succeeds silty clays of the Klintinghoved Formation (Fig. 54). This boundary may be difficult to locate but is typically placed where the consistently decreasing-upward gamma-ray trend of the uppermost Klintinghoved Formation is succeeded by the 'noisy', serrated pattern of the Arnum Formation (e.g. Fig. 54; Kvong borehole, Plate 4).

The upper boundary is placed at the base of the first significant occurrence of grey fine-grained sand, commonly with a high content of heavy minerals, that is thicker than $5 \mathrm{~m}$ with a sand/mud ratio of at least $75 \%$. On the gammaray log, the upper boundary with the Stauning Member may be difficult to recognise but is marked by a shift from serrated and moderate-high gamma-ray values to low-moderate values, albeit still serrated in nature (e.g. Stauning borehole, Plate 6). At Rømø, in the far south-west (Plate 9), the Odderup Formation is absent and the Arnum Formation is overlain by the Hodde Formation (Måde Group); the boundary is placed at the shift from consistent moderate-high gamma-ray values to increasing-upward values.

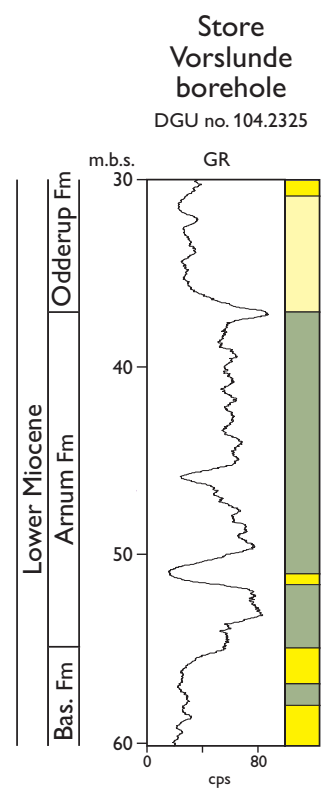

Fig. 55. The secondary reference section for the Arnum Formation is the interval from 55 to $37 \mathrm{~m}$ in the Store Vorslunde borehole; for legend, see Fig. 8, p. 17. Bas.: Bastrup. 

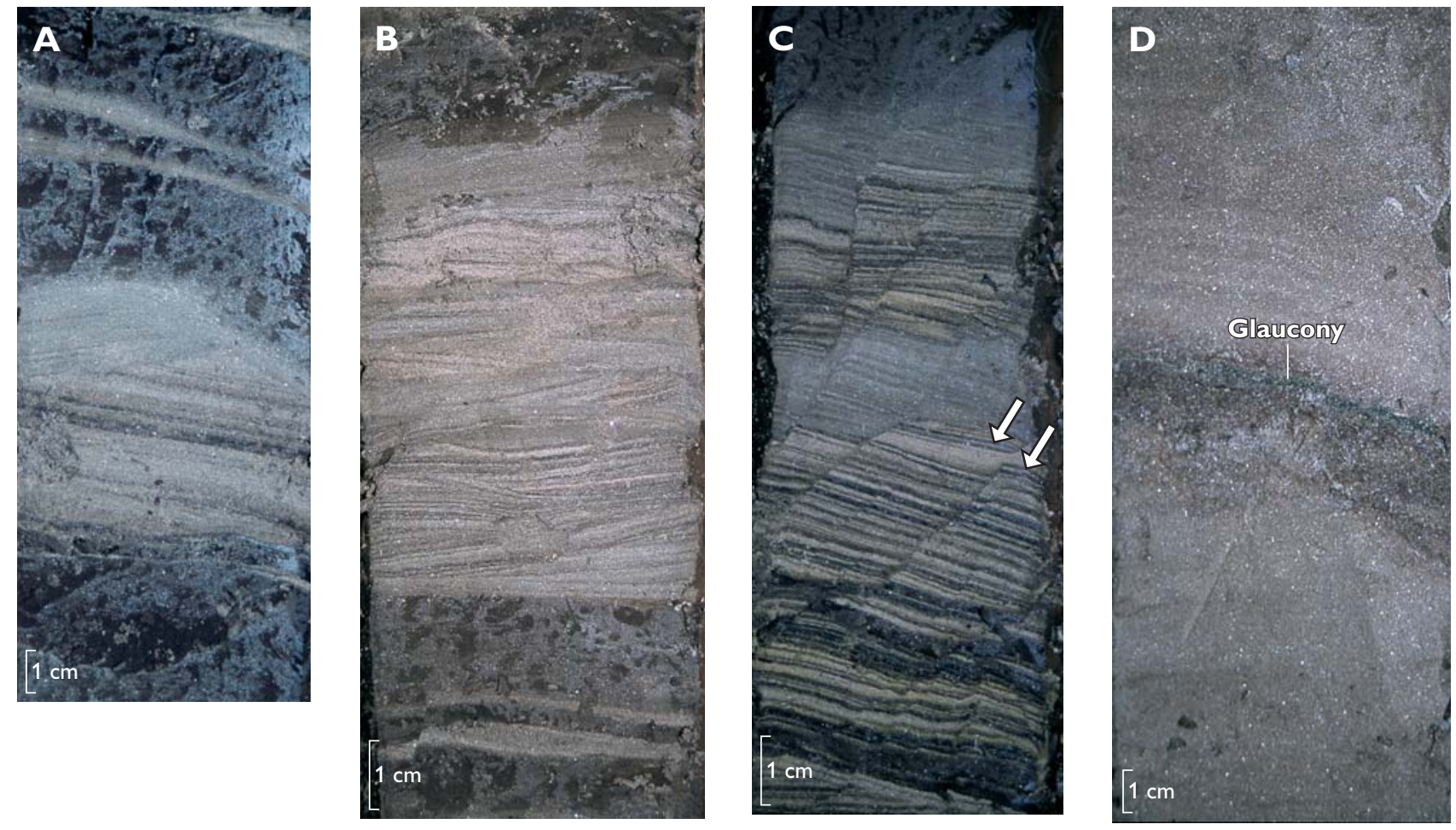

Fig. 56. Slabbed core sections from the Sdr. Vium borehole showing typical lithologies of the Arnum Formation. A: Dark brown clayey silt interbedded with hummocky cross-stratified sand; $59.20 \mathrm{~m}$ (base of illustrated core). B: Hummocky cross-stratified sand bed bounded by dark brown silty clays; $73.40 \mathrm{~m}$ (base). C: Heterolithic deposits showing double clay layers (arrows); $95.60 \mathrm{~m}$ (base). Note the small-scale faults cutting the succession, possibly due to contemporaneous seismic activity. D: Bioturbated clay with a $1 \mathrm{~mm}$ lamina rich in glaucony; $125.00 \mathrm{~m}$ (base).

Distribution. The formation is recognised in Jylland, southwest of a line from Struer to Horsens (Figs 1, 10F).

Biostratigraphy. The Cordosphaeridium cantharellus, Exochosphaeridium insigne, Cousteaudinium aubryae and Labyrinthodinium truncatum Dinocyst Zones of Dybkjær \& Piasecki (2010) occur in the Arnum Formation.

Geological age. The Arnum Formation is of Burdigalian to early Langhian (Early - early Middle Miocene) age.

Subdivision. The Arnum Formation includes the new Vandel Member.

\section{Vandel Member}

new member

General. The lack of exposure of this member precludes detailed description and environmental interpretation. It is defined as a discrete member of the Arnum Formation since it forms a recognisable marker interval between the coarse siliciclastics of the Bastrup Formation beneath and the mud-rich facies of the Arnum Formation above.

Name. After the village of Vandel, east of Billund (Fig. 1).

Type and reference sections. The type section is the interval from 114 to $102 \mathrm{~m}(112-102 \mathrm{~m} \mathrm{MD})$ in the Vandel Mark borehole (DGU no.115.1371; 5542'47.99' 'N, $9^{\circ} 10^{\prime} 54.82^{\prime \prime} \mathrm{E}$; Figs 1, 57). The reference section is the interval from 100 to $97 \mathrm{~m}(100-97 \mathrm{~m} \mathrm{MD})$ in the Grindsted borehole (DGU no. 114.2038; Fig. 57).

Thickness. The thickness of the member rarely exceeds the $12 \mathrm{~m}$ recorded in the borehole at Vandel Mark (Plate 7).

Lithology. In both the Vandel and the Grinsted boreholes, $\log$ and/or cuttings data indicate a lowermost sand or gravel layer, fining upwards into mud-rich deposits. The diagnostic feature of the Vandel Member, however, is the occurrence of grey to white silt with a high content of heavy minerals; clasts of reworked reddish Eocene clay may be present. 
Log characteristics. The member shows intermediate gamma-ray readings overall with subordinate low values near the base (sandy beds) and localised high peaks (? heavy mineral sands).

Fossils. No fossils have been recorded.

Depositional environment. The depositional setting is unclear but the member caps fluvio-deltaic deposits (Resen Member) of the Bastrup Formation. The absence of fossils could point towards a floodplain depositional environment.

Boundaries. The lower boundary is defined by a lithological shift from grey sand to grey and white silt as observed in borehole cuttings samples. This boundary is difficult to position on the gamma-ray log alone; a minor increase in values is observed in the type section (Fig. 57), followed by a weak increasing-upward trend.

The upper boundary is placed at the top of the interval of white to grey silt. A slight, but distinct decrease in gamma-ray values is recognised at the upper boundary in the type section.

Distribution. The member is recognised in central Jylland (Fig. 10F).

Biostratigraphy. The Vandel Member is barren of dinocysts, but the Cordosphaeridium cantharellus Dinocyst Zone (Dybkjær \& Piasecki 2010) occurs in the lithostratigraphic units below and above.

Geological age. The Vandel Member is of Burdigalian (late Early Miocene) age.

\section{Odderup Formation}

redefined formation

History. The Odderup Formation was defined by L.B. Rasmussen (1961), from the borehole at Odderup Brickworks where the succession of brown coal and quartz sand from 40.3 to $28.2 \mathrm{~m}$ was defined as the type section. Koch (1989) subsequently erected the Fasterholt Member and included this in the Odderup Formation. The formation is redefined here, based on the more extensive subsurface database now available, to include the marine sand-dominated succession, commonly rich in heavy minerals, that is associated with the largely terrestrial sediments recognised in the early work.

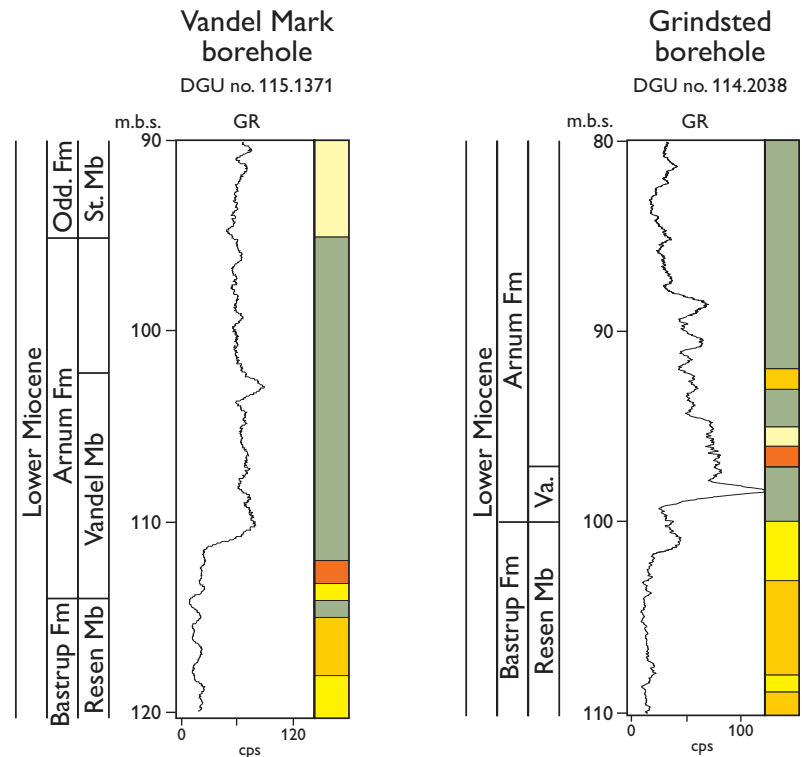

Fig. 57. Type and reference sections of the Vandel Member. The type section is the interval from 114 to $102 \mathrm{~m}$ in the Vandel Mark borehole. The reference section is the interval from 100 to $97 \mathrm{~m}$ in the Grindsted borehole; for legend, see Fig. 8, p. 17. Odd.: Odderup. St.: Stauning. Va.: Vandel Mb.

Name. After Odderup village in western Jylland (Fig. 1).

Type and reference sections. Following L.B. Rasmussen (1961), the type section is the borehole at Odderup (DGU no. $103.150 ; 55^{\circ} 52^{\prime} 19.05^{\prime \prime} \mathrm{N}, 8^{\circ} 37^{\prime} 42.28^{\prime \prime} \mathrm{E}$ ) from 40.3 to $28.2 \mathrm{~m}$. The formation is exposed at the Abildaa Brown Coal Museum near Ørnhøj but only the brown-coal-bearing Fasterholt Member is present here. The primary reference section is the interval from 37 to $1 \mathrm{~m}$ (39-1 m MD) in the borehole at Store Vorslunde (DGU no. 104.2325). The secondary reference section illustrates the alternation of the Odderup and Arnum Formations that is observed in a number of boreholes (Plates 2-9); the Odderup Formation is represented in the intervals from 118 to 110 $\mathrm{m}(118-111 \mathrm{~m} \mathrm{MD})$ and 90 to $41 \mathrm{~m}(90-42 \mathrm{~m} \mathrm{MD})$ in the Rødding borehole (DGU no. 141.1141; Fig. 58).

Thickness. The formation is $c .12 \mathrm{~m}$ thick at the type section and about $36 \mathrm{~m}$ thick in the primary reference section. In central Jylland, it commonly exceeds $40 \mathrm{~m}$ (Plates $2,7)$ and an exceptionally thick development was recorded in the Tinglev borehole (c. $165 \mathrm{~m}$; Plates 1, 9).

Lithology. The formation consists of fine- to coarse-grained sand with some intercalation of clay beds and brown coal. The formation consists of quartz and clast of quartzites 
with minor content of mica. Heavy minerals are locally very common. The sand is characterised by low-angle crossbedding dipping towards the south-west, and is enriched in heavy minerals (Fig. 59). The fine-grained part of the formation is dominated by hummocky cross-stratified sand and homogenous to laminated sand.

The Odderup Formation is characterised by a succession of sand with subordinate clay layers; the Odderup Formation is differentiated from the Arnum Formation in being sand-dominated with a sand/mud ratio of at least $75 \%$ and a minimum thickness of $5 \mathrm{~m}$.

Log characteristics. The formation is characterised by low to moderate gamma-ray values (Fig. 58); an overall decreasing-upward gamma-ray trend is typical. High gamma-ray values are associated with beds rich in heavy minerals.

Fossils. Marine molluscs as well as dinocysts occur in the south-western sections of the Odderup Formation (Stauning Member; Piasecki 1980; Dybkjær \& Piasecki 2010). Foraminifers reported from coarser-grained (more proximal) intervals (Laursen \& Kristoffersen 1999) may be the result of caving from higher strata. Fossil seeds, leaves and wood are abundant in coal beds and lacustrine sands and muds of the terrestrial Fasterholt Member.

Depositional environment. The Odderup Formation was deposited in the lower to upper shoreface and swash zone of a prograding coastal-plain (Odderup Formation undifferentiated and Stauning Member). The coals and associated sediments are the deposits of freshwater lakes, lagoonal swamps and mires (Fasterholt Member; Koch 1989).

Boundaries. The lower boundary is placed where fossiliferous, dark brown, silty clays with subordinate, fine-grained sand layers referred to the Arnum Formation are overlain by a significant thickness ( $>5 \mathrm{~m}$ ) of grey fine-grained sand (sand: mud $>75 \%$ ), commonly with a high content of heavy minerals. On the gamma-ray log, the lower boundary may be an abrupt shift to lower values, particularly where the Fasterholt Member directly overlies the Arnum Formation. This boundary may be more difficult to locate where the Stauning Member forms the lowermost Odderup Formation but the increase in the proportion of sand at this level is generally reflected by a fall in the gamma-ray values (e.g Ulfborg borehole, Plate 5).

The upper boundary is a marked change in lithology from the white, fine- to medium-grained sand of the Odderup Formation to the dark brown, clayey silt of the Hodde Formation. The boundary is typically sharp but locally is marked by a gravel layer, the base of which defines the

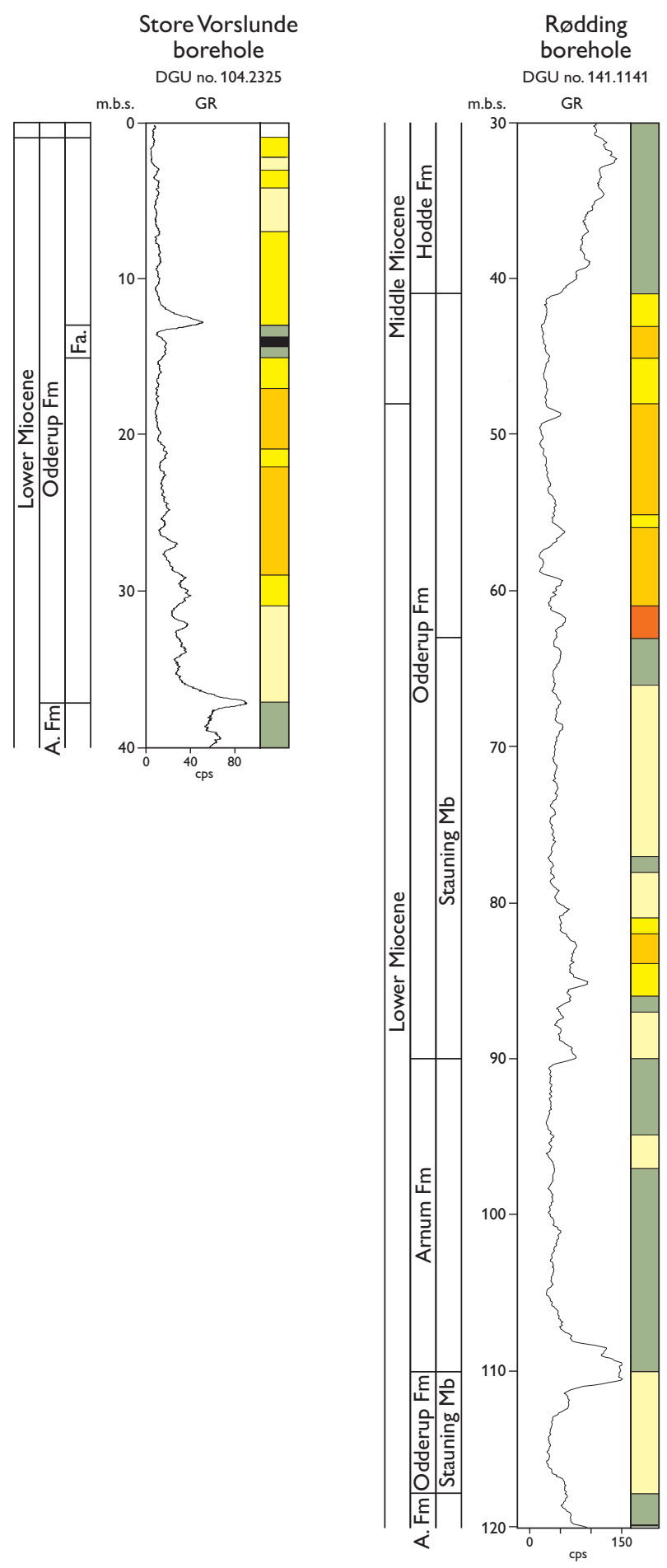

Fig. 58. Reference sections of the Odderup Formation; for legend, see Fig. 8, p. 17. The primary reference section is the interval from 37 to $1 \mathrm{~m}$ in the Store Vorslunde borehole. The secondary reference section is the composite interval $(118-110 \mathrm{~m}, 90-41 \mathrm{~m})$ in the Rødding borehole. A.: Arnum. Fa.: Fasterholt Mb.

boundary. The gamma-ray log typically shows a prominent shift (to higher values) at the boundary. 
Fig. 59. Exposure (Isenvad gravel pit) of the Odderup Formation showing lowangle cross-bedded sand with concentrations of dark heavy minerals; the sand was deposited in the swash zone of a beach. The height of the illustrated section is $0.4 \mathrm{~m}$.

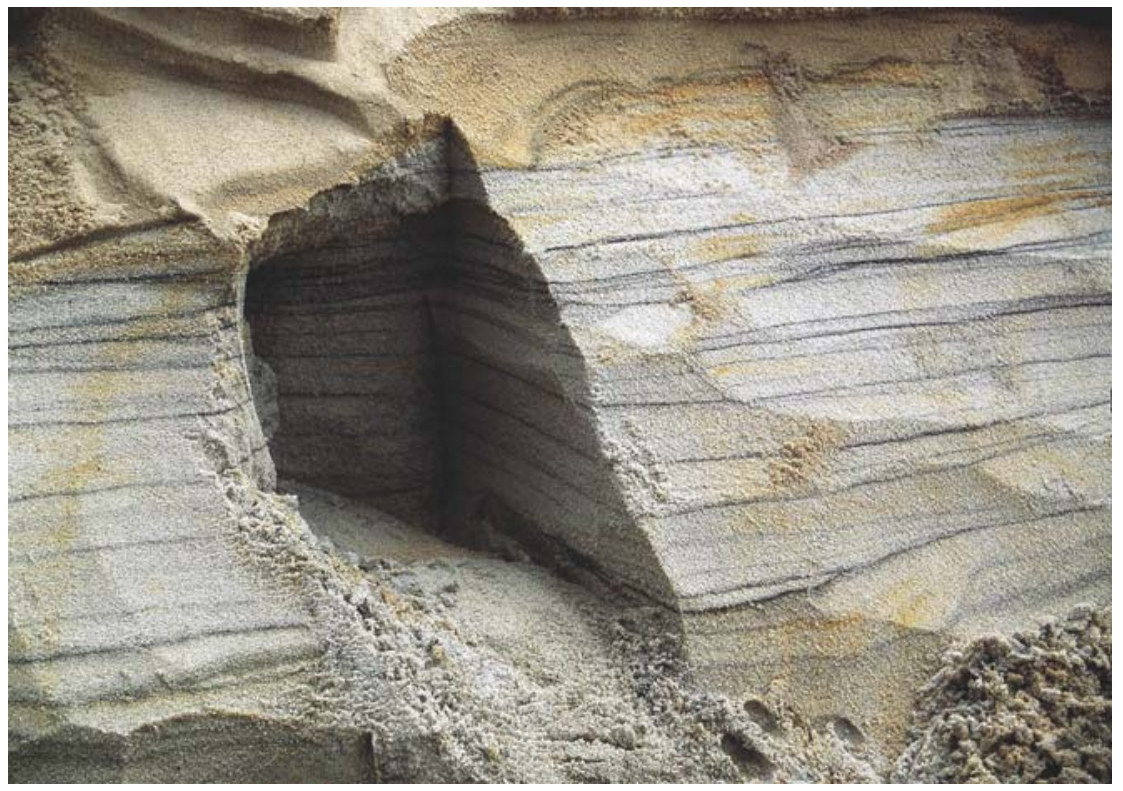

Distribution. The Odderup Formation is distributed in west, central and southern Jylland (Fig. 10G).

Biostratigraphy. The Cordosphaeridium cantharellus, Exochosphaeridium insigne, Cousteaudinium aubryae and Labyrinthodinium truncatum Dinocyst Zones of Dybkjær \& Piasecki (2010) occur in the marine parts of the Odderup Formation.

Geological age. The Odderup Formation is of Burdigalien to early Langhian (Early to earliest Middle Miocene) age.

Subdivision. The Odderup Formation includes the new Stauning Member and the Fasterholt Member (Koch 1989).

\section{Stauning Member}

new member

History. Knudsen et al. (2005) recognised that fine-grained sand layers with a high content of heavy minerals occurred in the Arnum Formation in a number of boreholes in south and central Jylland; these sand layers were informally referred to as the 'Stauning Sand'. On gamma-ray logs, the sand beds are characterised by extremely high gamma-ray values. Exploration for these heavy mineral sands was intensive during the latter part of the 1990s in the Stauning and Give areas.

Name. After the village of Stauning (Fig. 1) where the member subcrops Quaternary deposits at relatively shallow depths.
Type and reference sections. The type section of the Stauning Member is defined in the interval from 95 to $76 \mathrm{~m}$ (95-76 $\mathrm{m}$ MD) in the Vandel Mark borehole (DGU no. 115.1371; $55^{\circ} 42^{\prime} 47.99^{\prime \prime} \mathrm{N}, 9^{\circ} 10^{\prime} 54.82^{\prime \prime} \mathrm{E}$; Fig. 60). The reference section is the intervals from 118 to $110 \mathrm{~m}$ (118-111 m MD) and 90 to $63 \mathrm{~m}$ (90-64 m MD) in the Rødding borehole (DGU no. 141.1141; Fig. 60).

Thickness. Intervals referred to the Stauning Member commonly range from 10 to $40 \mathrm{~m}$ in thickness (e.g. Plates 2, 3 ), but over $100 \mathrm{~m}$ has been found in the extreme southern part of the study area, for example in the Tinglev borehole (Plate 9).

Lithology. Intervals assigned to the Stauning Member, by definition, have a sand/mud ratio of at least $75 \%$ and are more than $5 \mathrm{~m}$ thick. The member is typically composed of grey to white, fine-grained sand, with a high content of heavy minerals, intercalated with dark brown, clayey silt (Fig. 61).

Log characteristics. The member typically shows a highly serrated gamma-ray log (e.g. Plate 6, Stauning borehole) although some sections show more stable low gamma-ray values (e.g. Tinglev borehole, Plate 9). Extremely high gamma-ray readings (e.g. Kvong borehole, Plate 4; Løvlund borehole, Plate 7) are found in association with concentrations of heavy minerals.

Fossils. Marine molluscs occur in the Stauning Member (Knudsen 1998) as well as foraminifers and dinocysts (Laursen \& Kristoffersen 1999; Dybkjær \& Piasecki 2010). 


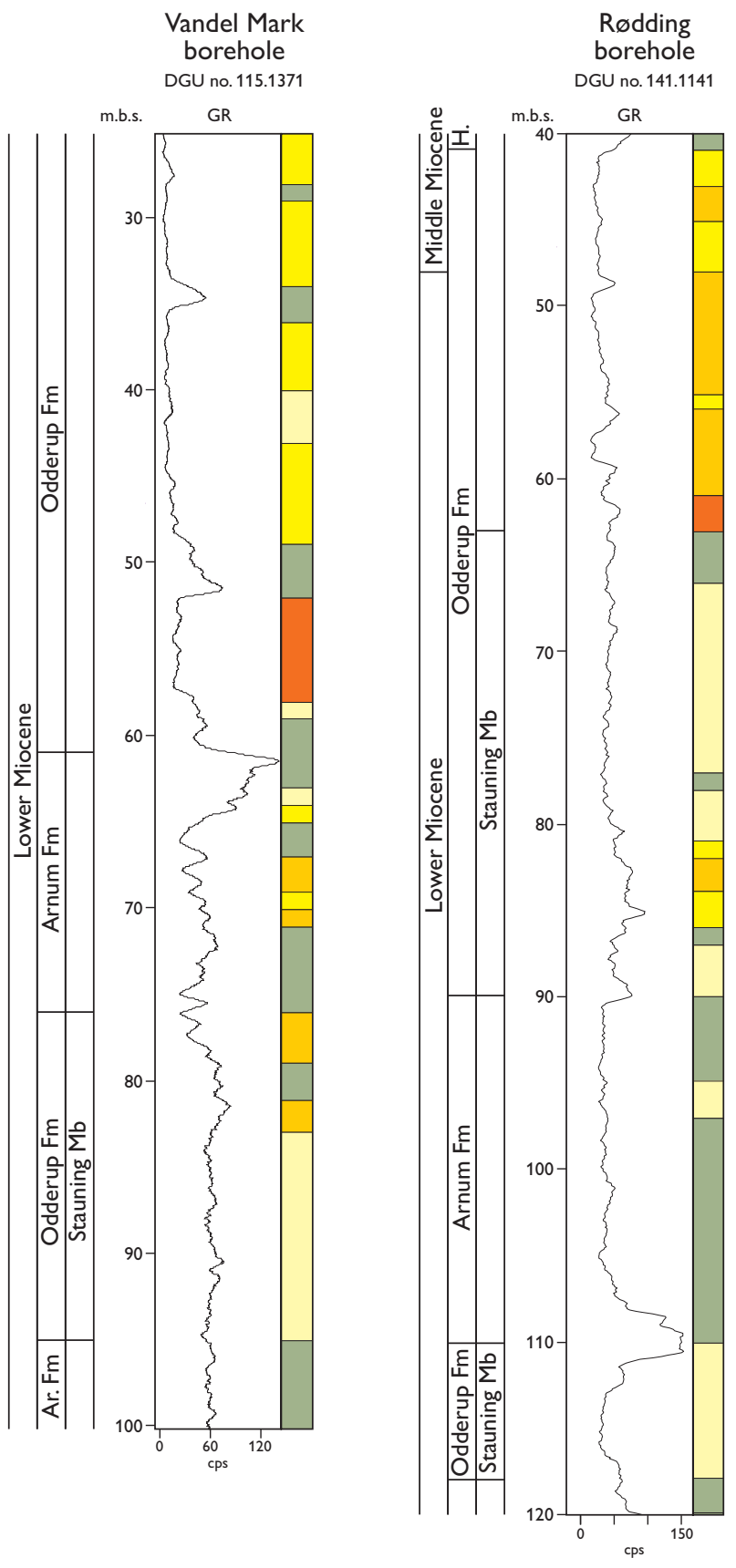

Fig. 60. Type and reference sections of the Stauning Member; for legend, see Fig. 8, p. 17. The type section is the interval from 95 to $76 \mathrm{~m}$ in the Vandel Mark Borehole. The reference section is the composite interval (118-110 m, 90-63 m) in the Rødding borehole. Ar.: Arnum. H.: Hodde Fm.

Depositional environment. The Stauning Member was deposited as storm sand layers on the inner shelf, the sands being primarily of storm origin.

Boundaries. The lower boundary is placed at the base of sanddominated (>75\% sand) successions at least $5 \mathrm{~m}$ thick,
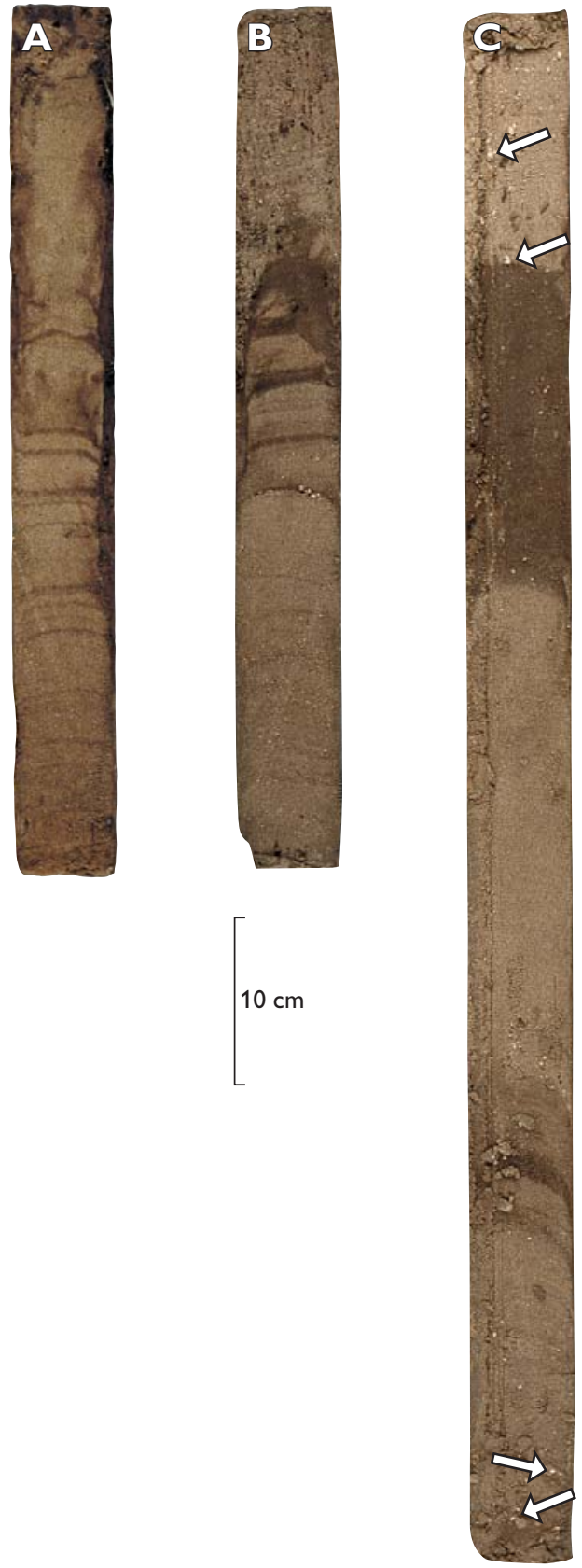

Fig. 61. Cores of the Stauning Member showing homogenous to laminated, grey sand with some intercalated dark brown muds. Note the high content of shells in $\mathbf{C}$ (arrows), especially in the lower part of the sand beds. A: $15.72 \mathrm{~m}$ (base of illustrated core); B: 23.73 $\mathrm{m}$ (base); C: $26.94 \mathrm{~m}$ (base). Cores from a shallow borehole to investigate the heavy mineral potential of Stauning Member sands; $2 \mathrm{~km}$ due west of Skjern.

overlying the mud-rich Arnum Formation. In some wells, this boundary is marked by a general upward decrease in the background gamma-ray values (e.g. Hellevad borehole, Plate 1; Føvling borehole, Plate 3) but anomalous exam- 
ples are also observed (e.g. Rødding borehole, Fig. 60), possibly due to the heavy mineral content of the sands.

The upper boundary is defined where the fine-grained sand-rich succession is overlain by dark brown, silty clay of the Arnum Formation or medium- to coarse-grained sand of the Odderup Formation. Where the Odderup Formation succeeds the Stauning Member, the upper boundary is commonly reflected by a shift from a dominantly serrated gamma-ray log pattern to a steady and gradually decreasing gamma-ray log pattern (e.g. Plates 1,2).

Distribution. The Stauning Member is found in southern, central and western Jylland (Fig. 10G).

Biostratigraphy. The Cordosphaeridium cantharellus, Exocho sphaeridium insigne, Cousteaudinium aubryae and Labyrinthodinium truncatum Dinocyst Zones of Dybkjær \& Piasecki (2010) are recognised in the Stauning Member.

Geological age. The Stauning Member is of Burdigalian to early Langhian (Early to earliest Middle Miocene) age.

\section{Fasterholt Member}

History. The Fasterholt Member was defined by Koch (1989). Brown-coal-bearing layers were mentioned by Forchhammer (1835) and brown-coal beds that crop out in the banks of the Skjern $\AA$ (river) were reported by Dalgas (1868) and Hartz (1909). Extensive mining of brown coal occurred during the two world wars and large prospecting programs were carried out in connection with the demands for local energy resources (Milthers 1939; Milthers 1949). Name. After the village of Fasterholt (Fig. 1).

Type and reference sections. The formation has previously been exposed in several brown-coal pits in central and western Jylland and the Fasterholt brown-coal pit $\left(56^{\circ} 00^{\prime} 52.60^{\prime \prime} \mathrm{N}\right.$, $\left.9^{\circ} 06^{\prime} 16.05^{\prime \prime} \mathrm{E}\right)$ is the type locality of Koch (1989; Figs 1, 62). The member is only exposed today in a small pit at Abildå near Ørnhøj (Fig. 1). The reference section is defined in the Store Vorslunde borehole (DGU no. 104.2325) from 15 to 13 m (15-13 m MD; Fig. 62).

Thickness. The member is $c .8 .5 \mathrm{~m}$ thick in the type section and is commonly about $10 \mathrm{~m}$ thick elsewhere in central Jylland (Plate 2). It is not recognised in south-west Jylland (Fig. 10G).

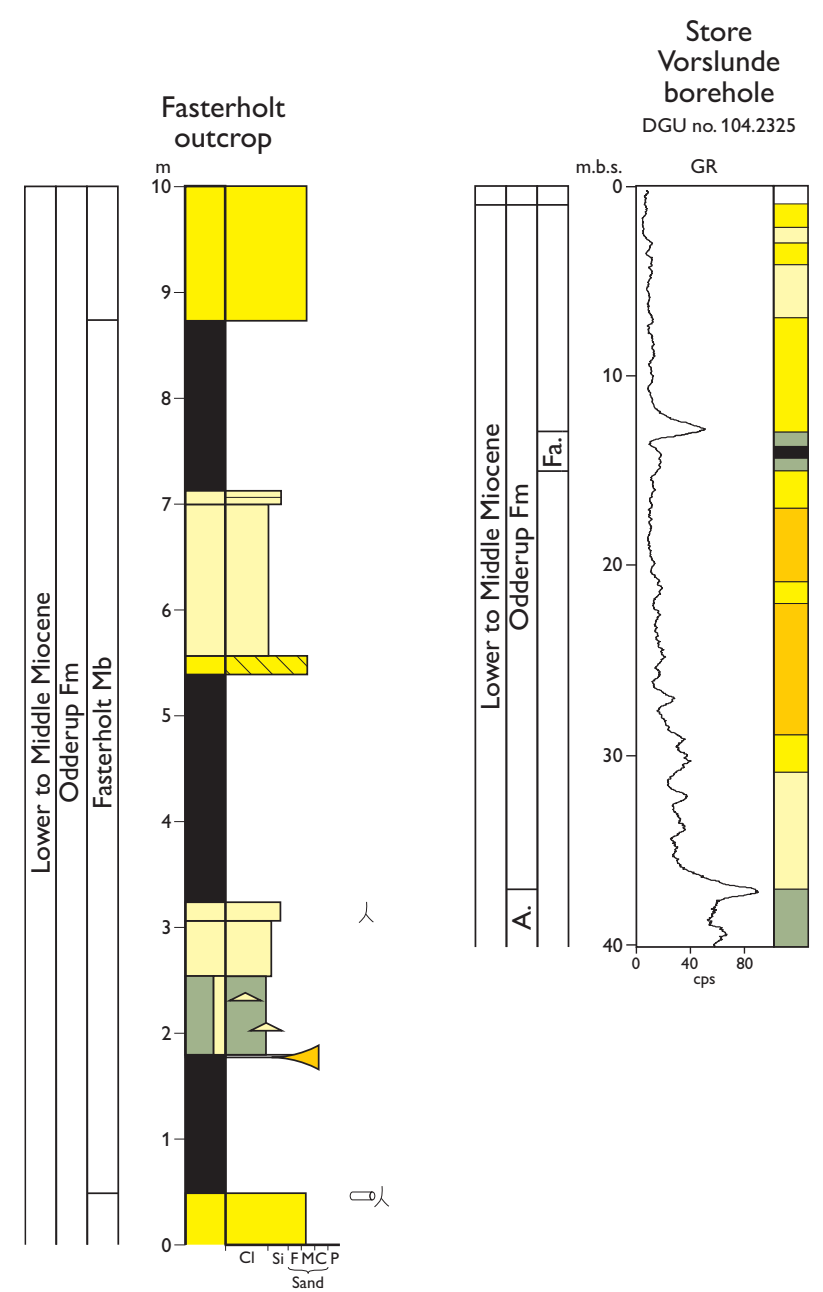

Fig. 62. Type and reference sections of the Fasterholt Member; for legend, see Fig. 8, p. 17. The type section is the Fasterholt Brown Coal Pit, north-west of Brande; this section is no longer exposed. The log is redrawn from Koch (1989). The reference section is the interval from 15 to $13 \mathrm{~m}$ in the Store Vorslunde borehole. A.: Arnum Fm. Fa.: Fasterholt Mb.

Lithology. The Fasterholt Member consists of interbedded sands, clays and brown coals. In the type section, it consists of three sedimentary units, each typically showing a fining-upward trend from a basal sandy lower part passing upward into silty clay and capped by a brown-coal layer (Fig. 62).

Fossils. Marine fossils are absent but spores and pollen, fossil seeds, leaves and wood occur abundantly (Christensen 1975, 1976; Friis 1975, 1979; Koch 1977, 1989; Koch \& Friedrich 1970; Koch et al. 1973; Wagner \& Koch 1974).

Depositional environment. The member is interpreted to represent deposition in a terrestrial setting that included lacustrine and mire environments (Koch 1989). The con- 
centration of brown coals in the depocentre of the Norwegian-Danish Basin, particularly adjacent to preexisting faults indicates a structural control on the deposition.

Boundaries. The lower boundary is sharp, being placed where white sands are overlain by a succession dominated by silty clay and brown coal, with intercalated sands. The lower boundary may be marked by a dense root horizon with tree stumps. On the gamma-ray log, the boundary is characterised by a prominent shift towards high gammaray values.

The upper boundary is also sharp, being typically marked by the incoming of the sand-rich upper part of the Odderup Formation; this lithological change is indicated on the gamma-ray log by a distinct shift to lower readings. Where overlain by clay-rich sediments of the Arnum Formation (e.g. Vind borehole, Plate 4) or the Hodde Formation (e.g.
Fjelstervang borehole, Plate 3), the gamma-log values show an abrupt increase.

Distribution. The Fasterholt Member is restricted to central Jylland (Fig. 10G).

Biostratigraphy. In the absence of marine fossils, the Fasterholt Member is stratigraphically constrained by the presence of the C. aubryae Dinocyst Zone below (in the marine Odderup or Arnum Formations) and the L. truncatum Dinocyst Zone above (in the overlying Arnum Formation) (Dybkjær \& Piasecki 2010).

Geological age. Due to the absence of marine fossils, the Fasterholt Member is dated indirectly by the biostratigraphy of the under- and overlying marine strata. The age of the Fasterholt Member is thus constrained to Burdigalian to early Langhian (Early to earliest Middle Miocene). 


\section{Måde Group}

new group

History. The succession defined here as the Måde Group was referred by L.B. Rasmussen (1961) to the 'Måde serien'; this encompassed the marine, clay-dominated younger Miocene deposits. As described by L.B. Rasmussen (1961), the succession is characterised by a basal gravel layer which is overlain by black, mica-rich mud followed by a thin greenish, glaucony-rich clay, grey clay and finally by fine- to mediumgrained sand. Relative to the North Sea lithostratigraphy, the Måde Group correlates with the Nordland Group (Deegan \& Scull 1977; Hardt et al. 1989; Schiøler et al. 2007).

Name. After a local area west of Esbjerg (Fig. 1) that was renowned for its brickworks based on Upper Miocene clays; the last brick factories were closed in the 1970s.

Type area. The type area of the Måde Group is south-west Jylland. The group is exposed at the Gram clay-pit (Fig. 1) where both the Gram and Marbæk Formations can be seen. At Ørnhøj (Lille Spåbæk), the Hodde and Ørnhøj Formations are exposed and the Marbæk Formation crops out in coastal cliffs at Sjelborg and Marbæk, north-west of Esbjerg (Fig. 1). The full development of the group is illustrated by the cored borehole Sdr. Vium (DGU no. 102.948; 51-24 m, Fig. 63) and the Tinglev borehole (DGU no. 168.1378) from 197 to $50 \mathrm{~m}$ (197- 49 m MD; Fig. 63).

Thickness. The group is typically about $25 \mathrm{~m}$ thick in the western part of Jylland, but in southernmost Jylland, for example in the Tinglev borehole, nearly $150 \mathrm{~m}$ has been penetrated (Fig. 63; Plate 9).

Lithology. The Måde Group is dominated by dark brown, organic-rich mud (Fig. 64). The lower part is composed of alternating fine-grained sand and silty clay with a basal gravel layer (Hodde Formation). Upwards, the succession becomes more fine-grained with scattered incursions of glaucony. This is succeeded by greenish brown, glauconyrich clay, typically $3 \mathrm{~m}$ thick (Ørnhøj Formation). In the upper part of the glaucony-rich section, goethification of glaucony grains is common (Dinesen 1976). This is overlain by a succession of brown clays rich in pyrite that becomes siltier upwards with thin (c. $5 \mathrm{~cm}$ thick), finegrained storm sand beds occurring in the upper part. The uppermost Måde Group consists of fine- to mediumgrained sand.

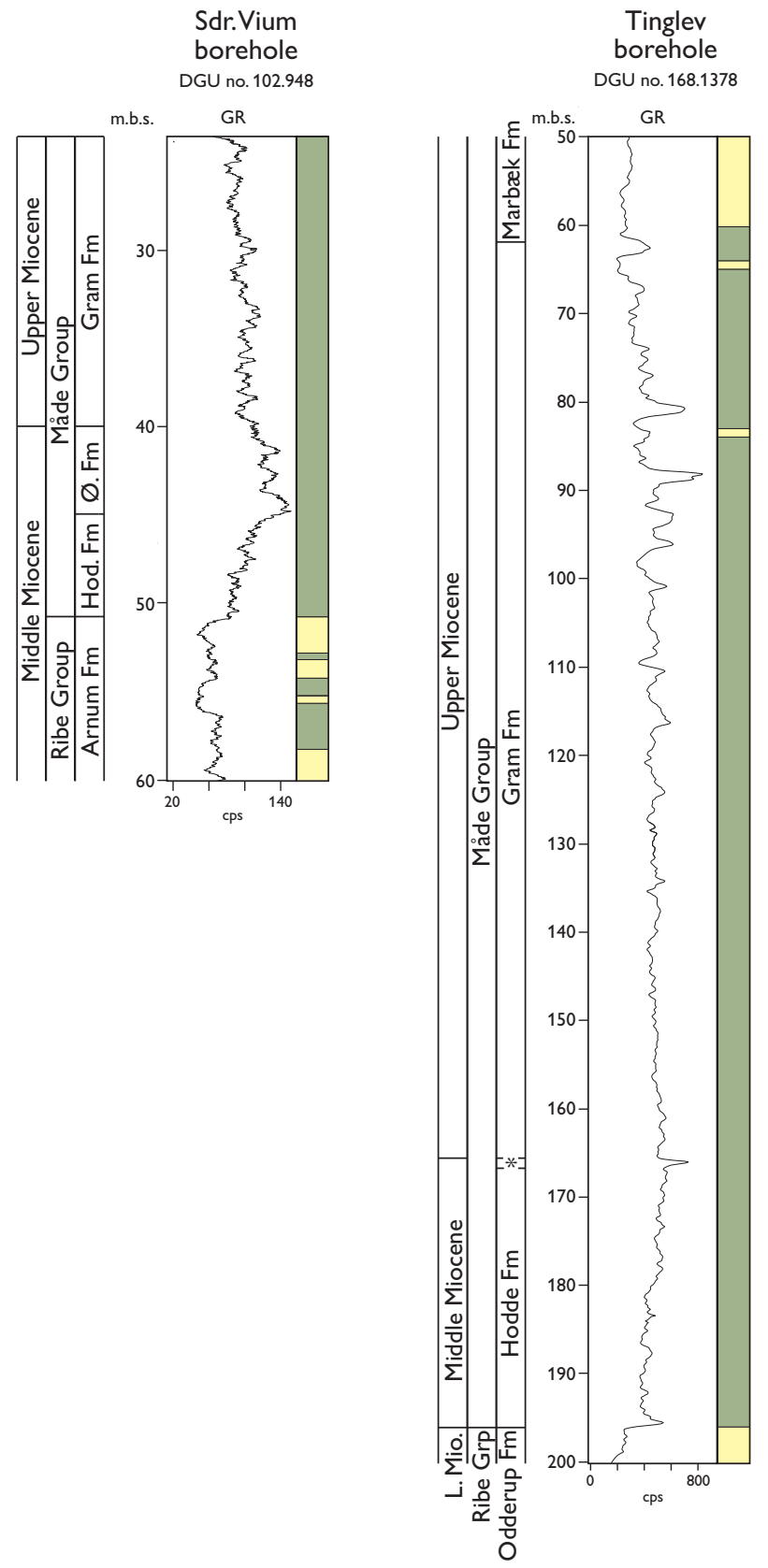

Fig. 63. The full development of the Måde Group is illustrated by the interval from 51 to $24 \mathrm{~m}$ in the cored Sdr. Vium borehole and the interval from 197 to $50 \mathrm{~m}$ in the Tinglev borehole; for legend, see Fig. 8, p. 17. Hod.: Hodde. L. Mio.: Lower Miocene. $\emptyset$ and *: Ørnhøj Fm.

Log characteristics. The group is characterised by moderate to high gamma-ray readings (Fig. 63). Extremely high gamma-ray values may be recorded in the lower levels of the group, the upper part showing a gradual decrease in gamma-ray readings (see Fig. 63). 


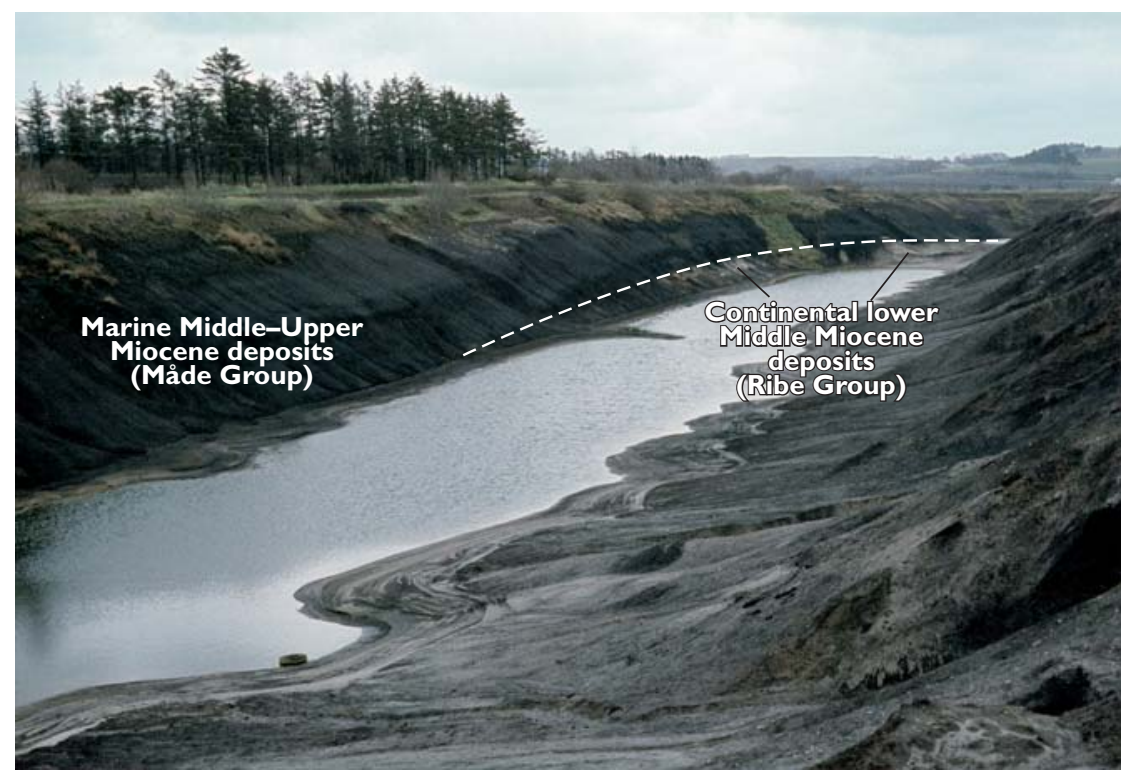

Fig. 64. The open pit at Lille Spåbæk, Ørnhøj (Fig. 1) where the Hodde, Ørnhøj and Gram Formations were exposed in the late 1970s. These three formations, together with the Marbæk Formation, constitute the Måde Group. The cliff is $c .10 \mathrm{~m}$ high.

Fossils. The Måde Group contains rich and diverse mollusc faunas, crustaceans and vertebrates. Shark teeth are common. Foraminifers and dinocysts are abundant (see details below in the description of the individual formations).

Depositional environment. The Måde Group was deposited on a marine shelf. When the flooding of the land was at its maximum, during the deposition of the glaucony-rich Ørnhøj Formation and the lower part of the Gram Formation, the water depth was over 100 m (Laursen \& Kristoffersen 1999). The upper part of the group was deposited in front of a prograding coastline in an offshore to shoreface setting.

Boundaries. The lower boundary is sharp, being marked by a thin gravel layer separating the white, fine-grained sand of the Ribe Group from the dark brown mud of the Måde Group. The upper boundary is a sharp erosional boundary separating mud and fine-grained sand of the Måde Group from Quaternary deposits, the boundary commonly being characterised by a distinct change in lithology and colour of the deposits.

Distribution. The Måde Group is restricted to the western and southern part of Jylland (Fig. 10H) and is found locally around Herning and in the Brande-Give area (Fig. 1).

Geological age. The Måde Group is of early Langhian to latest Tortonian (early Middle to Late Miocene) age.

Subdivision. The Måde Group is divided into four formations: the Hodde, Ørnhøj, Gram and Marbæk Formations.

\section{Hodde Formation}

History. The Hodde Formation was defined by L.B. Rasmussen (1961) from the Hodde-1 borehole; it was exposed during the construction (1941-43) of the

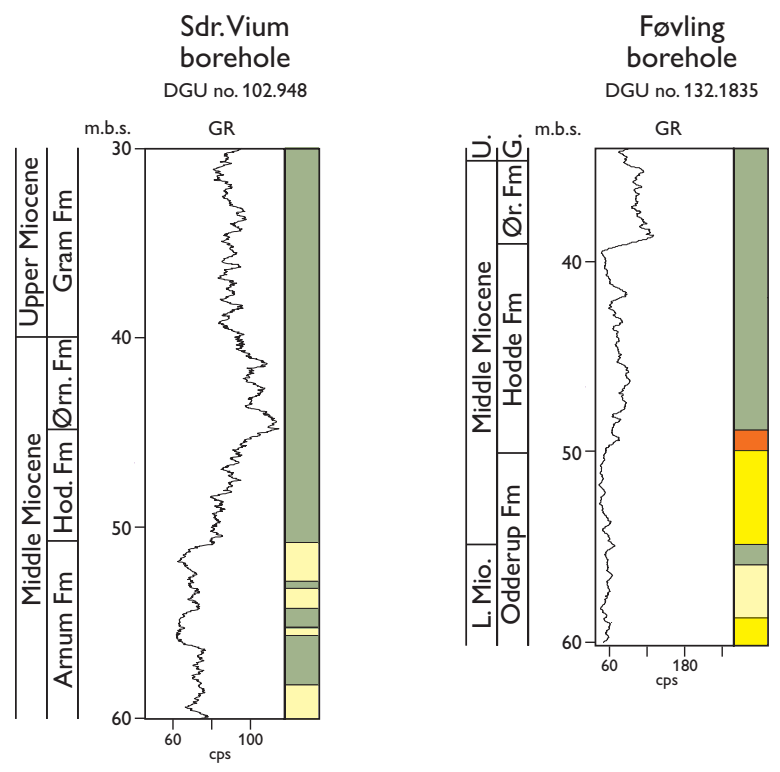

Fig. 65. Reference sections of the Hodde Formation; for legend, see Fig. 8, p. 17. The primary reference section is the interval from 51 to $44.9 \mathrm{~m}$ in the cored Sdr. Vium borehole. The secondary reference section is the interval from 50 to $39 \mathrm{~m}$ in the Føvling borehole. G.: Gram Fm. Hod.: Hodde. L. Mio.: Lower Miocene. U.: Upper Miocene. Ør. and Ørn.: Ørnhøj. 


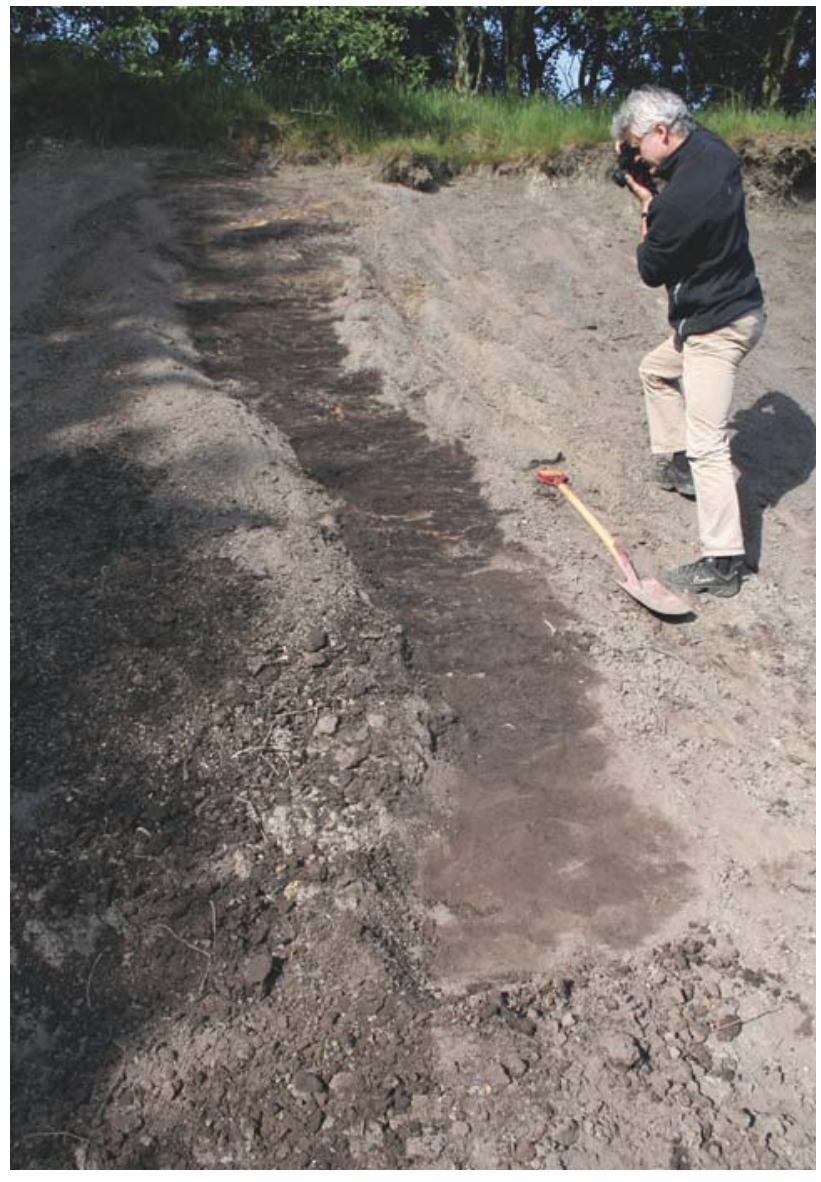

Fig. 66. The upper part of the Hodde Formation at Lille Spåbæk, Ørnhøj, dominated by dark brown silty clay.

Karlsgårde channel, near Hodde, but this exposure does not exist today.

Name. After the village of Hodde in south-west Jylland (Fig. 1).

Type and reference sections. The type section was defined by L.B. Rasmussen (1961) as the interval from 23.4 to 13.8 $\mathrm{m}$ in the Hodde-1 borehole (DGU no. 113.33; $\left.55^{\circ} 41^{\prime} 04.11^{\prime \prime} \mathrm{N}, 8^{\circ} 40^{\prime} 14.27^{\prime \prime} \mathrm{E}\right)$. The formation is exposed at Lille Spåbæk near Ørnhøj, south of Holstebro (Fig. 1). The primary reference section is the interval from 51 to $44.90 \mathrm{~m}$ in the cored borehole at Sdr. Vium (DGU no. 102.948; Fig. 65). A secondary reference section is the Føvling borehole (DGU no. 132.1835) from 50 to $39 \mathrm{~m}$ (Fig. 65).

Thickness. The formation is $9.6 \mathrm{~m}$ thick $(23.4-13.8 \mathrm{~m})$ in the type section and is typically $5-10 \mathrm{~m}$ thick where pre-

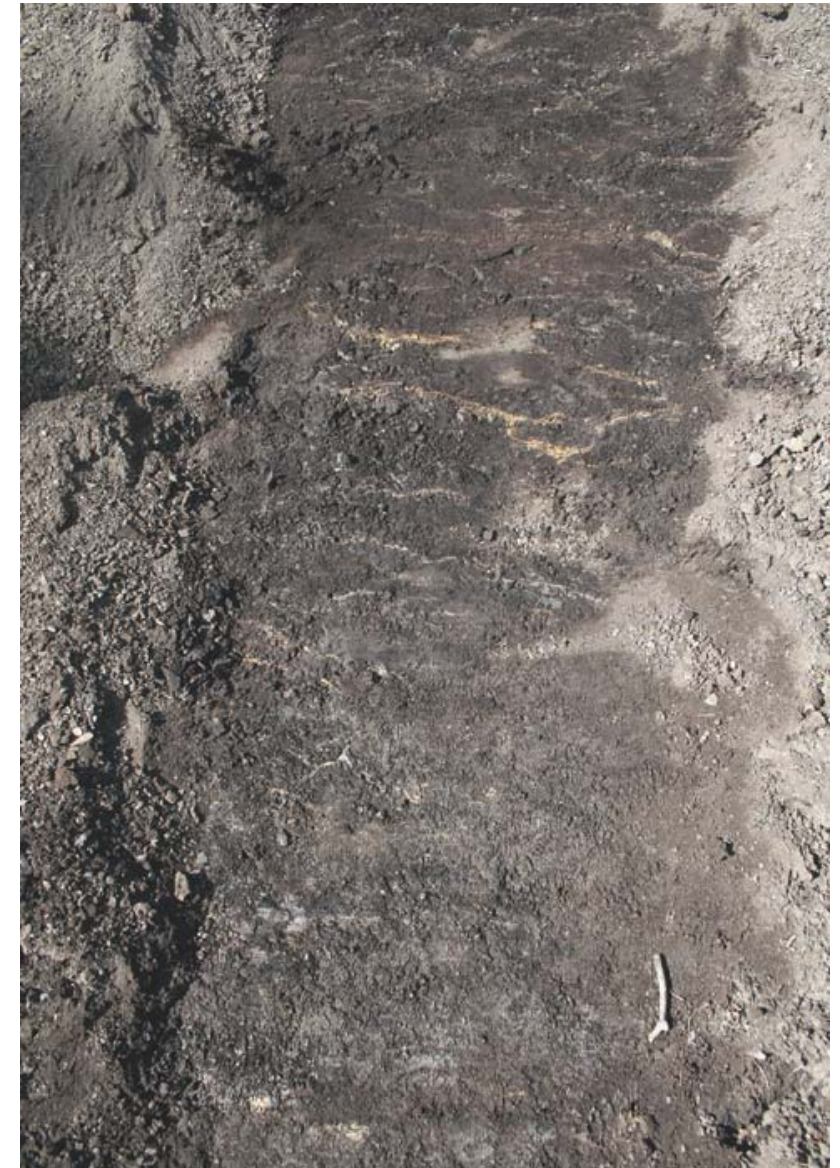

Fig. 67. Close-up of the Hodde Formation at Lille Spåbæk, Ørnhøj. The Hodde Formation is composed of dark brown silty clay; the yellowish stripes are due to weathering of pyrite. The illustrated section is $0.5 \mathrm{~m}$ high.

sent, but thickens in southernmost Jylland; more than 40 m was penetrated in the Rømø borehole (Plate 9).

Lithology. The Hodde Formation consists of dark brown, organic-rich, bioturbated silty clay with thin sand lenses (Figs 66, 67); the pyrite content is high. The basal part of the formation is composed of a thin gravel layer. In the upper part of the formation, laminated, silty clay is common and glaucony may occur. Trace fossils are common in the Hodde Formation (Asgaard \& Bromley 1974).

Log characteristics. The formation is typified by moderate to high gamma-ray values (Fig. 65); a gradual upward increase in gamma-ray response is characteristic. Locally, the upper part shows low gamma-ray readings, for example in the Føvling borehole (Plate 8).

Fossils. The Hodde Formation typically contains a limited fauna of marine molluscs (L.B. Rasmussen 1966) but a 
richer fauna occurs locally in shell-beds associated with the basal gravel bed. Marine microfossils, such as foraminifers and dinocysts, occur abundantly (Laursen $\&$ Kristoffersen 1999; Piasecki 1980, 2005; Dybkjær \& Piasecki 2010).

Depositional environment. The depositional environment is interpreted as fully marine (L.B. Rasmussen 1961). The basal coarse-grained transgressive lag indicates deposition on a marine shoreface during the initial transgressive phase. The increase in glaucony in the upper part indicates a near cessation of sediment influx to this part of the North Sea in the Serravallian.

Boundaries. There is a marked change in lithology from the white, fine- to medium-grained sand of the Odderup Formation to the overlying dark brown, clayey silt of the Hodde Formation. The boundary is sharp and is commonly characterised by a gravel layer, the base of which (where present) defines the boundary. The gamma-ray log shows a prominent shift to high values at the lower boundary.

The upper boundary is defined by an abrupt change from dark brown, clayey silt of the Hodde Formation to greenish brown clay of the Ørnhøj Formation. On the gamma-ray log, this is reflected by a distinct shift towards higher gamma-ray values.

Distribution. The Hodde Formation is recognised in southern and western Jylland (Fig. 10H). The formation occurs locally as far east as Bording and Give in central Jylland in depressions associated with salt structures.

Biostratigraphy. The upper part of the Labyrinthodinium truncatum Dinocyst Zone and the Unipontidinium aquaeductum Dinocyst Zone (Dybkjær \& Piasecki 2010) are recorded in the Hodde Formation.

Geological age. The Hodde Formation is of early Langhian to mid-Serravallian (Middle Miocene) age.

\section{Ørnhøj Formation}

new formation

History. Formerly referred to as the 'Glauconitic Clay member' of the lower Gram Formation of previous usage (L.B. Rasmussen 1956, 1961).

Name. After the village of Ørnhøj (Fig. 1) where the formation is still exposed in some of the old brown-coal pits in the neighbourhood.

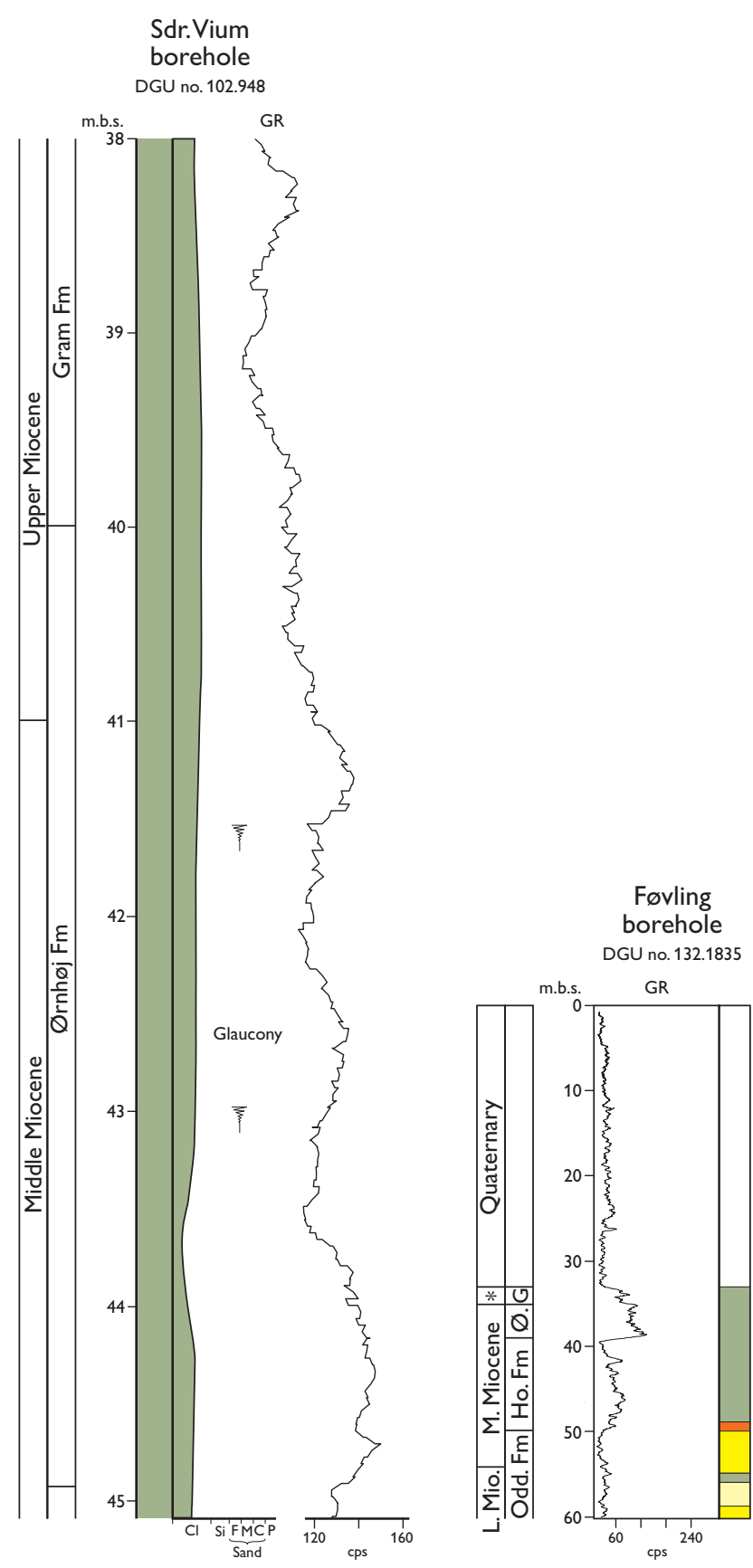

Fig. 68. The type and reference sections of the Ørnhøj Formation; for legend, see Fig. 8, p. 17. The type section is the interval from 44.9 to $40 \mathrm{~m}$ in the cored Sdr. Vium borehole. The reference section is the interval from 39 to $36 \mathrm{~m}$ in the Føvling borehole. G: Gram Fm. Ho.: Hodde. L. Mio.: Lower Miocene. M.: Middle. Odd.: Odderup. Ø.: Ørnhøj Fm. *: Upper Miocene.

Type and reference sections. The formation is partly exposed at Lille Spåbæk, west of Ørnhøj (Figs 1, 64). The type section is the interval from 44.90 to $40 \mathrm{~m}$ in the cored borehole at Sdr. Vium (DGU no. 102.948; 55 $49^{\prime} 04.02^{\prime \prime} \mathrm{N}$, $8^{\circ} 24^{\prime} 46.52^{\prime \prime} \mathrm{E}$; Fig. 68). The reference section is the inter- 
Fig. 69. The Ørnhøj Formation at Lille Spåbæk, Ørnhøj. The lower boundary with the Hodde Formation beneath is seen in the lower part of the section. Knife for scale, c. $20 \mathrm{~cm}$ long.

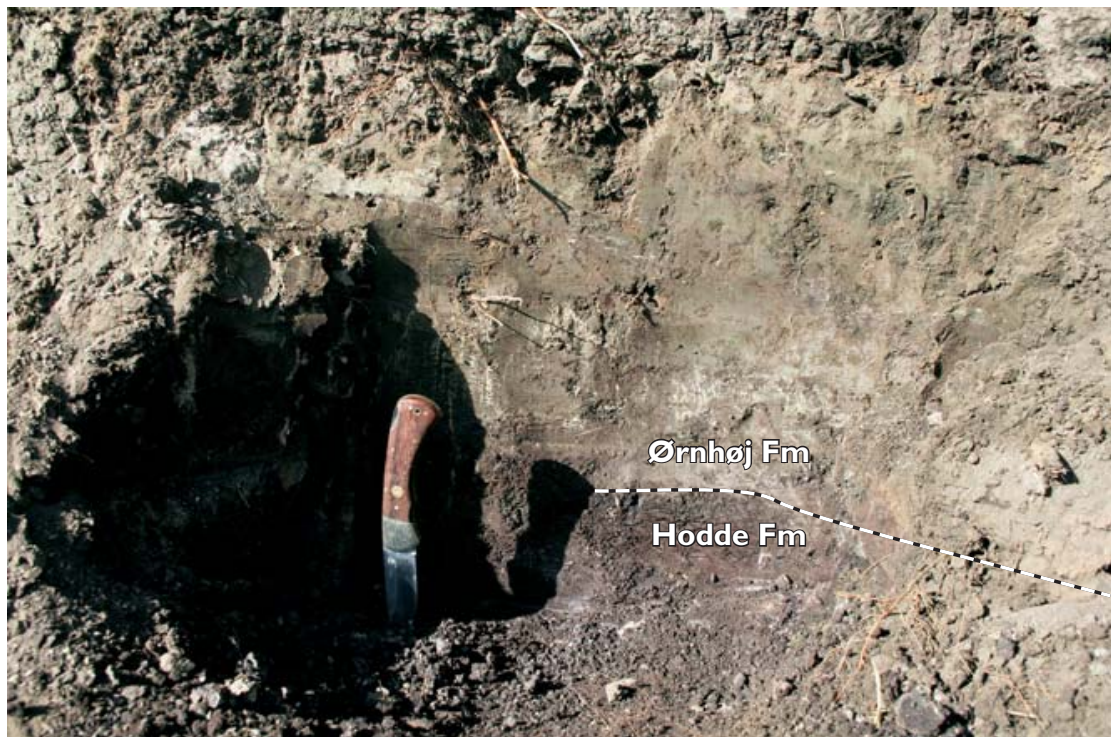

val from 39 to $36 \mathrm{~m}$ (39-36 m MD) in the Føvling borehole (DGU no. 132.1835; Fig. 68).

Thickness. The formation is $4-5 \mathrm{~m}$ thick in the type and reference boreholes, but in general it rarely exceeds more than $2 \mathrm{~m}$ in thickness (Plates 4, 8, 9).

Lithology. The Ørnhøj Formation is composed of green and brown clay (Fig. 69). High concentrations of green glaucony pellets of fine sand grade occur commonly. In the upper part of the formation, goethification of glaucony is common.

Log characteristics. The formation is characterised by high gamma-ray values.

Fossils. The Ørnhøj Formation is barren of macro- and microscopic calcareous fossils but a diverse assemblage of dinocysts is present (Piasecki 1980, 2005; Dybkjær \& Piasecki 2010).

Depositional environment. The Ørnhøj Formation was deposited in a fully marine, sediment-starved depositional setting that favoured the formation of glaucony. The water depth was probably more than $100 \mathrm{~m}$, based on the estimates of water depth during deposition of the Gram Formation (see below). The Ørnhøj Formation represents the most widespread transgression during the Miocene (E.S. Rasmussen 2004b; Knox et al. 2010). The goethification of glaucony in the upper part is interpreted as a result of a sea-level fall (Dinesen 1976; Eder et al. 2007) with associated wave action at the sea floor. Concentration of glaucony in depositional bars at Ørnhøj (J. Frederiksen, personal communication 2009) supports the interpretation of wave action at the sea floor.

Boundaries. The lower boundary is characterised by an abrupt change from the dark brown, clayey silts of the Hodde Formation to greenish brown clays of the Ørnhøj Formation (Fig. 69). The gamma-ray log shows a prominent shift in gamma-ray response towards high values.

The upper boundary is defined by the change from greenish brown or brown, glaucony-rich clay to dark brown clay. At the boundary there is an abrupt change from glaucony-impregnated pellets and shells to pyritised pellets. On the gamma-ray log, the upper boundary is defined at a decrease in gamma-ray values; locally a very prominent decrease is observed, for example in the Stensig borehole (Plate 4).

Distribution. The Ørnhøj Formation is recognised in southern and western Jylland. The formation is locally recognised in the subsurface as far east as Bording and Give in central Jylland, where it occurs in depressions associated with salt structures (Fig. 10H).

Biostratigraphy. The Achomosphaera andalousiense and Gramocysta verricula Dinocyst Zones of Dybkjær \& Piasecki (2010) are recorded in the Ørnhøj Formation.

Geological age. The Ørnhøj Formation is of late Serravallian (late Middle Miocene) age. 


\section{Gram Formation}

redefined formation

History. The Gram Formation was defined by L.B. Rasmussen (1956). In the original definition of the Gram Formation, three members were recognised: the Glauconite Clay, Gram Clay and Gram Sand members (L.B. Rasmussen 1956). The Glauconite Clay member of previous usage is herein redefined as the new Ørnhøj Formation and the Gram Sand member as the Marbæk Formation; the redefined Gram Formation thus equates to the Gram Clay member of L.B. Rasmussen (1956).

Name. After the town of Gram (Fig. 1).

Type and reference sections. The type section is at the dis-

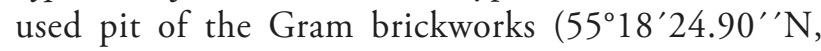
$9^{\circ} 03^{\prime} 31.26^{\prime \prime} \mathrm{E}$; Fig. 1), now the Midtsønderjyllands Museum of Gram, where a $13.1 \mathrm{~m}$ thick section of the Gram Formation is exposed (Figs 70, 71). The reference section is the interval from 40 to $24 \mathrm{~m}$ in the cored borehole Sdr. Vium (DGU no. 102.948; Fig. 71).

Thickness. A $13.1 \mathrm{~m}$ section is seen at the type section, but neither the base nor the top is exposed. In the reference section, the formation is about $16 \mathrm{~m}$ thick. The formation thickens south-westward and $105 \mathrm{~m}$ was penetrated in the Tinglev borehole (Plate 1).

Lithology. The Gram Formation consists of dark brown clay, which becomes more silty upwards. In the upper part, a few, fine-grained, wave-rippled sand beds, c. $5 \mathrm{~cm}$ thick, are intercalated with the clays (Figs 70, 71). Siderite concretions are common in the lower part of the formation. Pyrite is common both as pyritised pellets and in trace fossils; the latter include common Trichichnus ispp. (Rasmussen \& Larsen 1989; Bromley 1996).

Log characteristics. The formation is characterised by moderate gamma-ray values (Fig. 71). The log pattern is serrated and shows a general decreasing-upward trend in gamma-ray values through the succession (Fig. 63).

Fossils. The Gram Formation is characterised by abundant and diverse mollusc faunas, in association with marine vertebrates (whales and sharks) and crustaceans (crabs), the latter in concretionary nodules (L.B. Rasmussen 1966, 1968; Bendix-Almgreen 1983; Hoch 2008; Schnetler 2005; Steeman, 2009). Foraminifers and dinocysts are abundant (Laursen \& Kristoffersen 1999; Piasecki 1980, 2005).

Depositional environment. The Gram Formation was deposited in a fully marine environment with water depths of more than 100 m (Laursen \& Kristoffersen 1999; C. Morigi, personal communication 2010). The incoming of storm beds in the upper part is interpreted to reflect progradation of the shoreline (Rasmussen \& Larsen 1989).

Boundaries. The lower boundary is defined at the change from greenish brown or brown, glaucony-rich clay to dark brown clay, associated with an abrupt change from glaucony-impregnated pellets and shells to pyritised pellets. On the gamma-ray $\log$, this is reflected by a decrease in gamma-ray values.

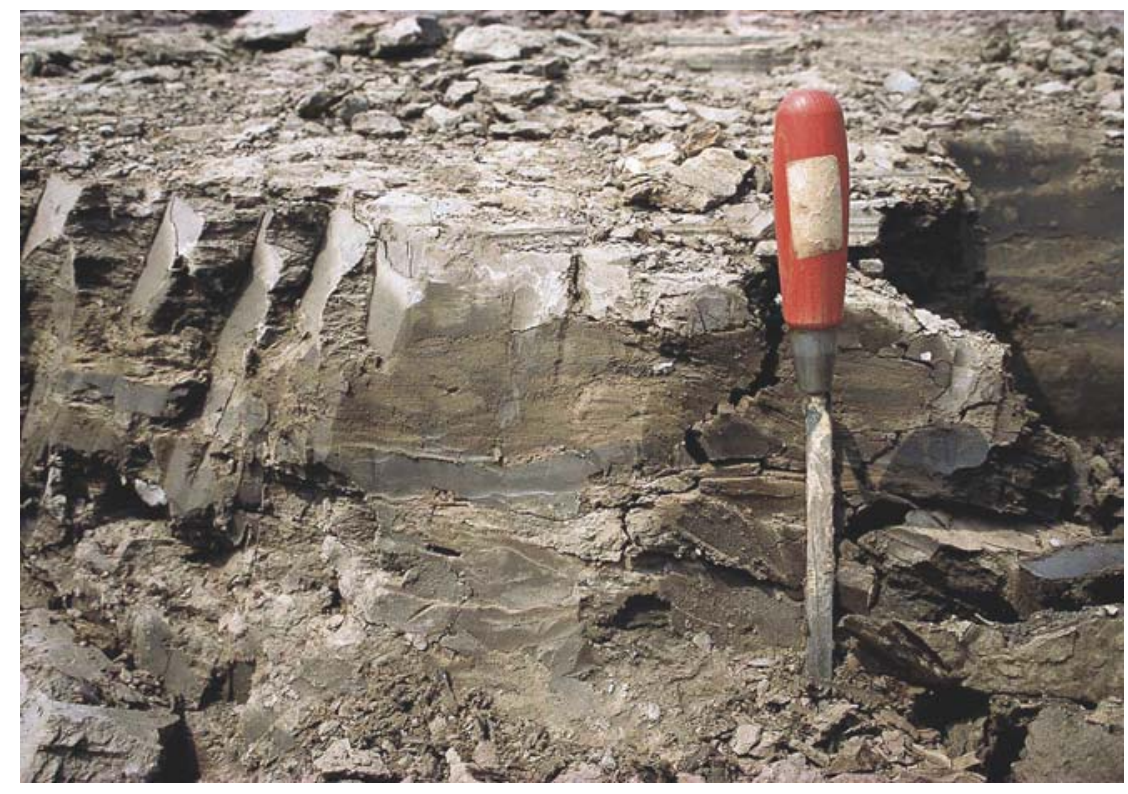

Fig. 70. Fine-grained, partly bioturbated sand interbeds in the upper part of the Gram Formation, Gram clay pit. The sand beds are commonly wave-rippled. The illustrated section is $0.30 \mathrm{~m}$ high.

\section{Facing page:}

Fig. 71. Type and reference sections of the Gram Formation; for legend, see Fig. 8, p. 17. The type section is at the Gram clay pit near Gram, where $13.1 \mathrm{~m}$ of the formation is exposed. The reference section is the interval from 40 to $24 \mathrm{~m}$ in the cored Sdr. Vium borehole. 


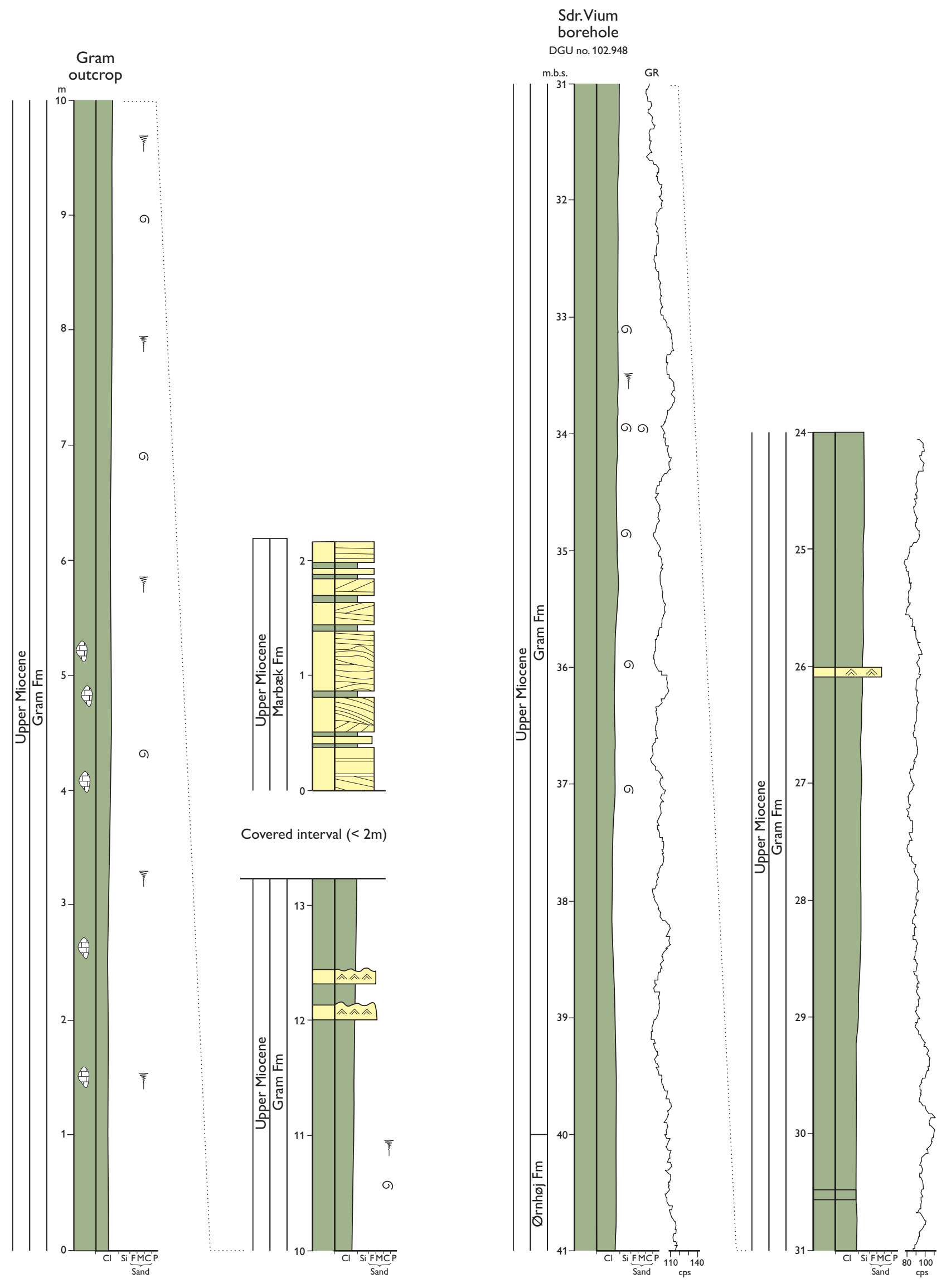


The upper boundary is placed where interbedded clay and thin sand layers are succeeded by amalgamated sand beds. On the gamma-ray log, the upper boundary is identified by a marked shift to consistently low gamma-ray values.

Distribution. The Gram Formation is recognised in the subsurface of southern and western Jylland (Fig. 10H). The formation occurs locally as far east as Bording and Give in central Jylland in depressions associated with salt structures.

Biostratigraphy. The Amiculasphaera umbracula and Hystrichosphaeropsis obscura Dinocyst Zones of Dybkjær \& Piasecki (2010) are recorded in the Gram Formation.

Geological age. The Gram Formation is of Tortonian (Late Miocene) age.

\section{Marbæk Formation}

new formation

History. Sands exposed in the cliffs at Sjelborg and Marbæk, north-west of Esbjerg (Fig. 1), and sandy sediments in the upper part of the Sæd borehole (DGU no. 167.445) were tentatively referred to the Pliocene by Jørgensen (1945). New studies of these sections (Piasecki et al. 2003), however, indicated that these deposits are Tortonian in age. The sand was informally named the Gram Sand member (Gram Formation of previous usage) by L.B. Rasmussen (1956).

Name. After the coastal cliff at Marbæk, north-west of Esbjerg (Fig. 1).

Type and reference sections. The type section is the exposure at Marbæk cliff $\left(55^{\circ} 32^{\prime} 56.49^{\prime \prime} \mathrm{N}, 8^{\circ} 18^{\prime} 57.49^{\prime \prime} \mathrm{E}\right.$; Figs 1, 72). The reference section is the interval from 62 to $50 \mathrm{~m}$ (62-49 $\mathrm{m} \mathrm{MD}$ ) in the Tinglev borehole (DGU no.168.1378; Fig. 73).

Thickness. The Marbæk Formation is $c .16 \mathrm{~m}$ thick in the Marbæk cliff (Fig. 72); neither the base nor the top is exposed. In the pit at the Gram brickworks, $1.5 \mathrm{~m}$ of the formation is exposed in the bank of a stream (Fig. 71). In

Fig. 72. Type section of the Marbæk Formation in the coastal cliff at Marbæk, north-west of Esbjerg, where $c .16 \mathrm{~m}$ of the formation are exposed; for legend, see Fig. 8, p. 17. Iron-stained fractures are conspicuous at $7-9 \mathrm{~m}$ in this section.
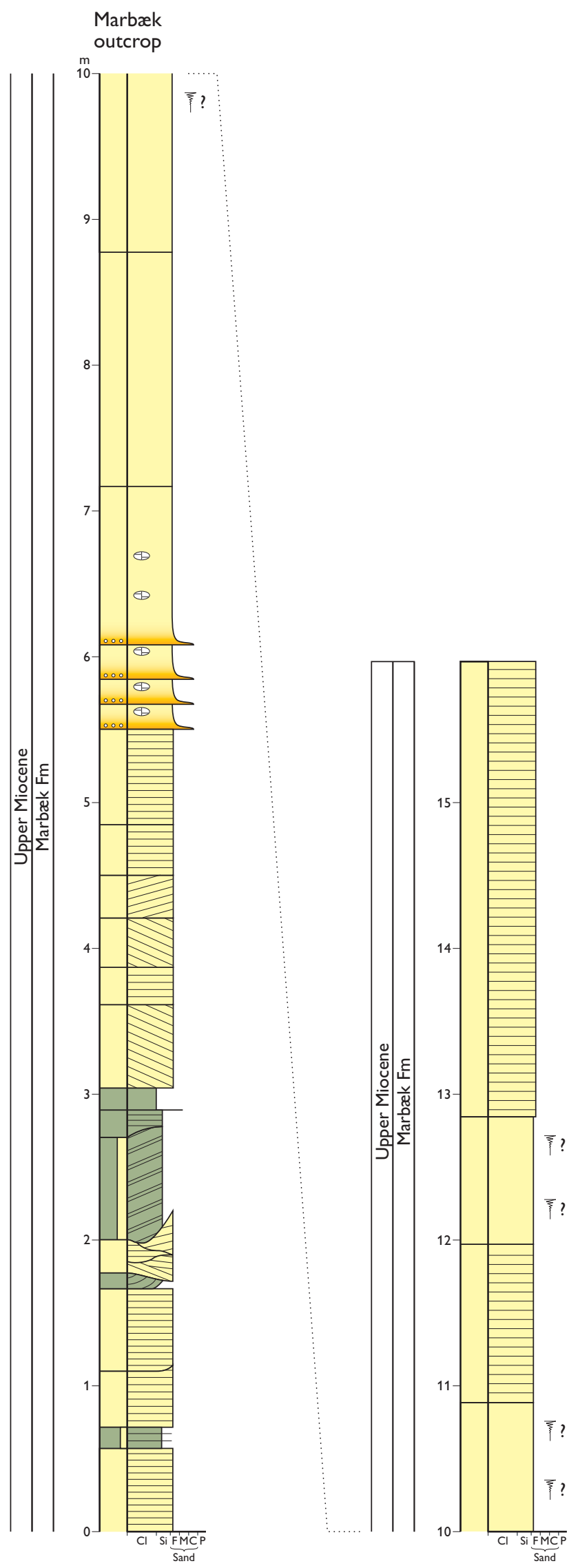


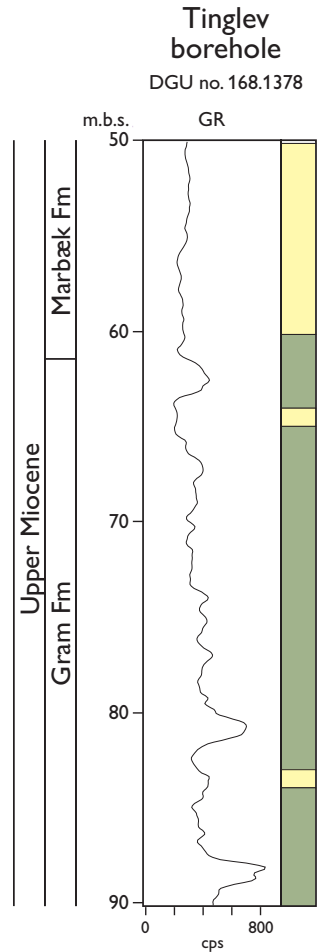

Fig. 73. Reference section for the Marbæk Formation is the interval from 62 to $50 \mathrm{~m}$ in the Tinglev borehole; for legend, see Fig. 8, p. 17. the Tinglev borehole, the formation is $10 \mathrm{~m}$ thick (Fig. 73, Plate 1), though the top is an unconformity with Quaternary sediments.

Lithology. In the type section, the formation is dominated by white, often reddish, fine- to medium-grained, mica-rich sand with a few thin intercalated coarse-grained sand or gravel layers and, in the lower part, subordinate silt-rich intervals (Figs 72, 74). The sand beds show parallel lamination with subordinate cross-bedding; hummocky crossstratification is common (Fig. 75). A silt-rich interval shows double clay layers. The uppermost white sand at Sjelborg consists of homogenous sand capped by wave-ripples (Fig. 76). The pyrite content is very high in the Marbæk Formation (Olivarius 2009) and the distinctive red colour of the succession at the Marbæk outcrop is due to oxidation of the pyrite.

Fossils. Rare, poorly preserved molluscs have been found in the Marbæk Formation (Jørgensen 1945). Dinocysts occur in the lower part of the formation but become scarce upwards (Piasecki et al. 2003).

Depositional environment. The formation was deposited in a storm-dominated environment within the upper and

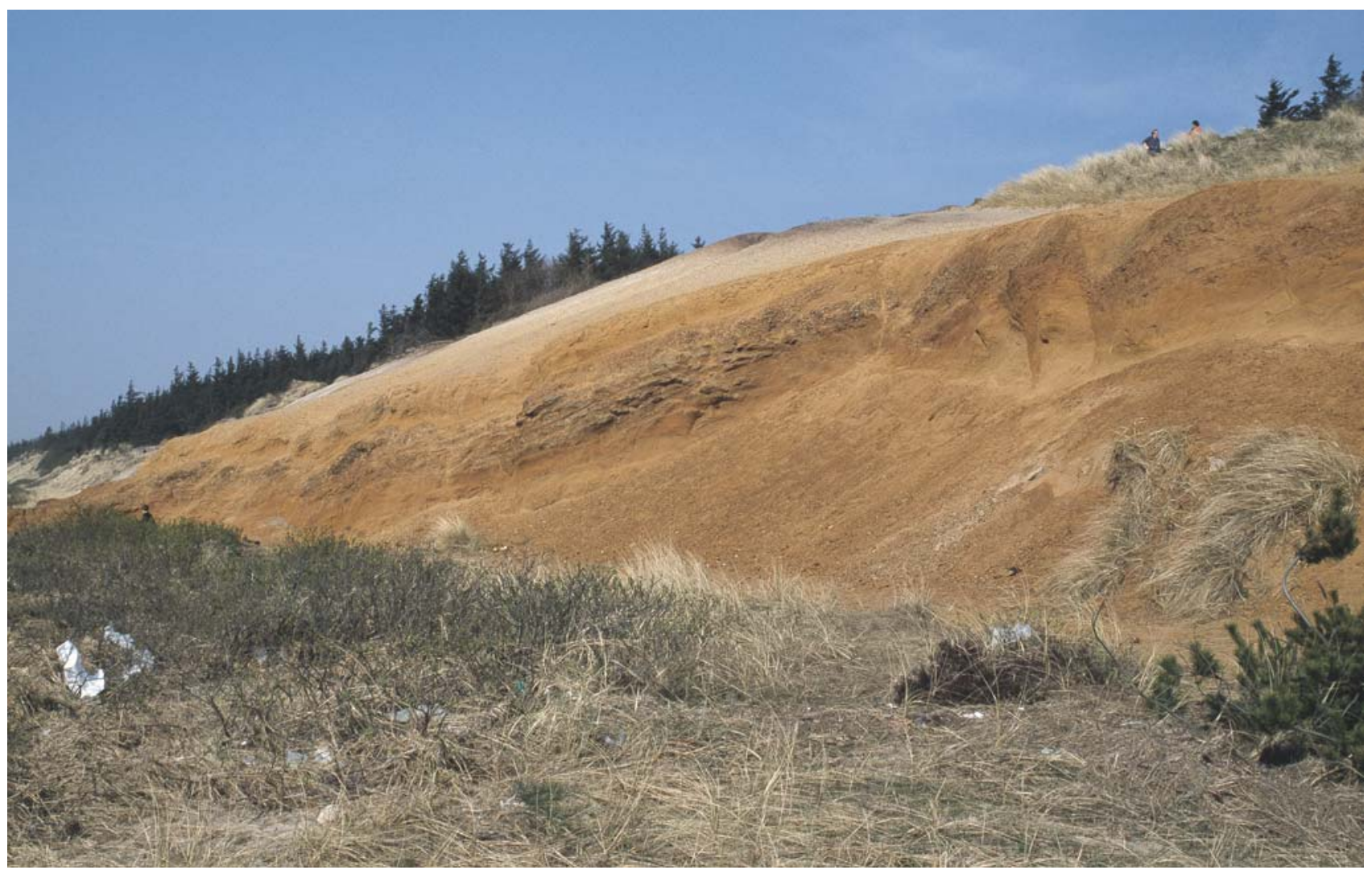

Fig. 74. Oblique view of the Marbæk Formation at Marbæk, north-west of Esbjerg. Two persons (upper right) for scale. 


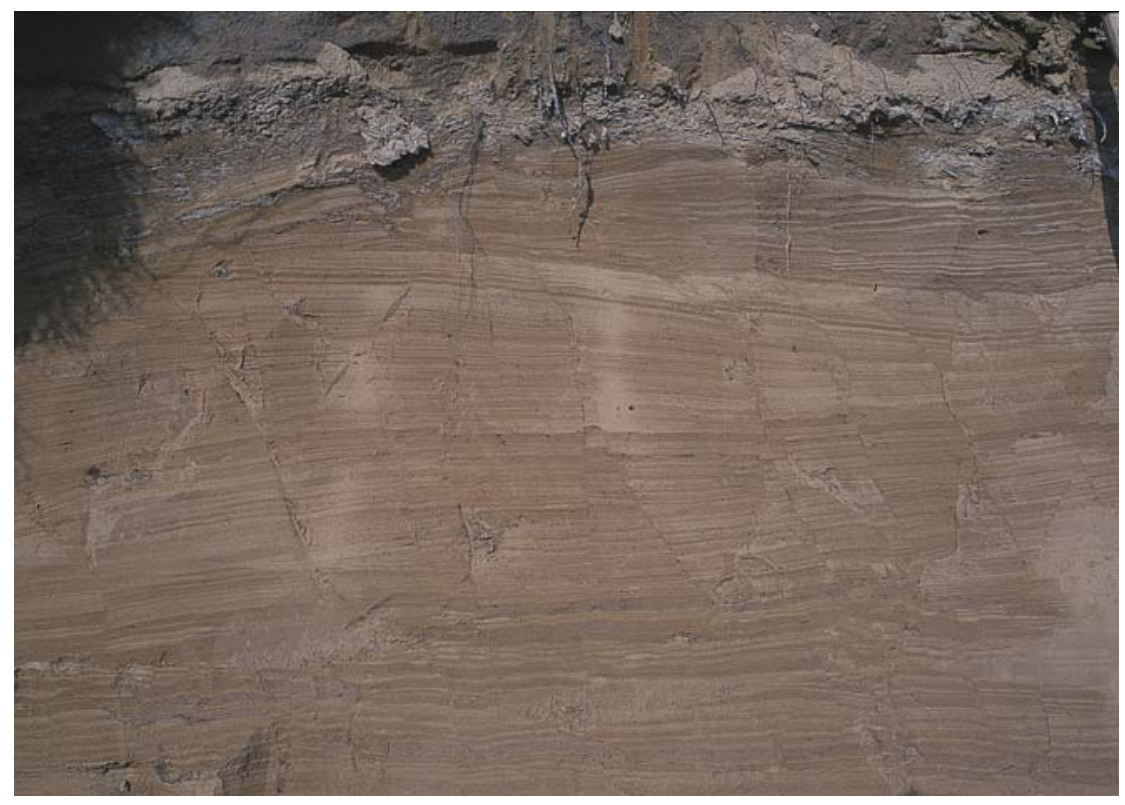

Fig. 75. Hummocky cross-stratified sand of the Marbæk Formation at Marbæk; the illustrated section is $50 \mathrm{~cm}$ high.

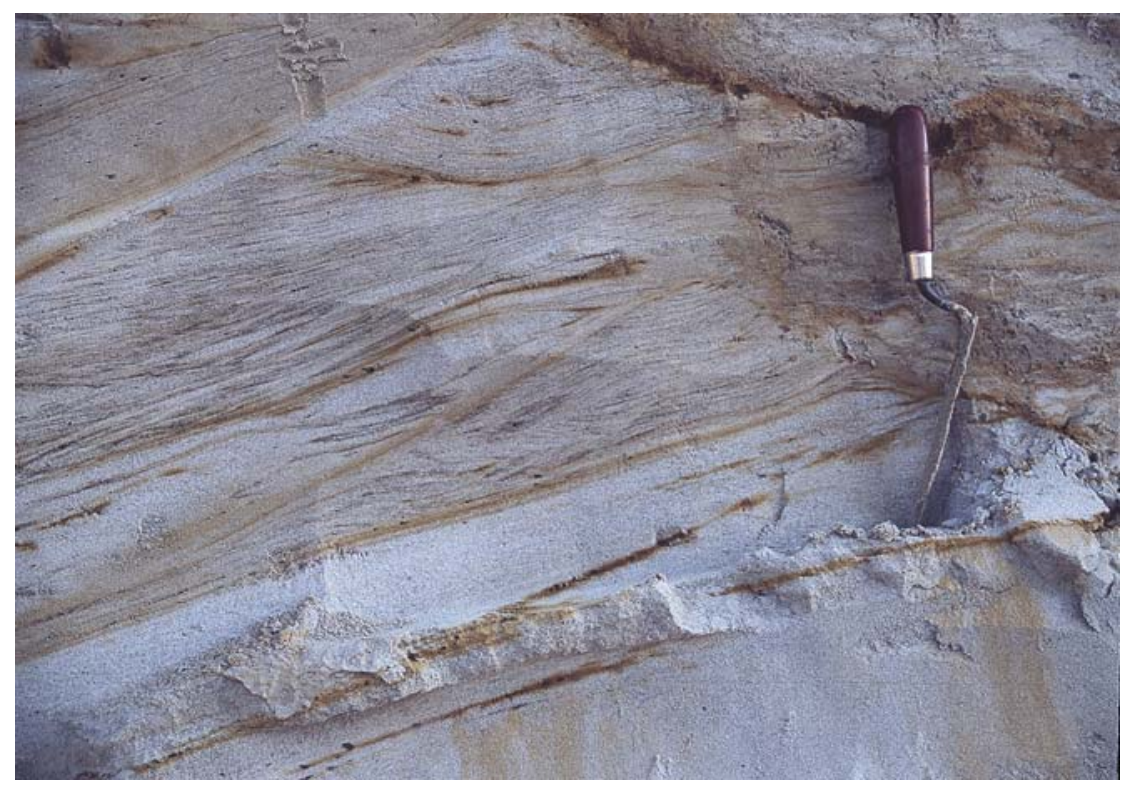

Fig. 76. Although deformed by glacial tectonics, the Marbæk Formation sands display homogenous and wave-rippled facies typical of upper shoreface deposits. The illustrated section is $0.4 \mathrm{~m}$ high; Sjelborg.

lower shoreface. Double clay layers indicate some tidal influence.

Boundaries. The lower boundary is defined where alternating thin clay and sand layers are overlain by amalgamated sand beds; this boundary is not observed at outcrop. On the gamma-ray log, this boundary is identified by a marked shift to steady low gamma-ray values.

The upper boundary is placed at a distinct, erosional unconformity separating the mica-rich sands from tills and yellowish, coarse-grained sands and gravels of Quaternary age.
Distribution. The formation is limited to the far west and south of Jylland.

Biostratigraphy. The Hystrichosphaeropsis obscura Dinocyst Zone of Dybkjær \& Piasecki (2010) is recorded in the lower part of the Marbæk Formation.

Geological age. The lower part of the Marbæk Formation is of Tortonian (Late Miocene) age, equivalent to the uppermost part of the Gram Formation. The absence of fossils in the upper levels of the formation precludes precise dating of this part. 


\section{Stratigraphic architecture}

The overall stratigraphic architecture of the Miocene succession is best revealed by integration of seismic data with outcrop and borehole data. Thus, in the grid of correlation panels presented here (Plates 1-9), the borehole and outcrop data provide the critical, stratigraphic constraints whilst the sedimentary architecture between wells is based in large part on the seismic data.

Inspection of seismic sections (Figs 77-79) reveals that the lower part of the Miocene succession is composed of two discrete, progradational successions (Fig. 77). The first succession includes the Vejle Fjord and Billund Formations and the second succession includes the Klintinghoved and Bastrup Formations. These packages are often characterised by a seismic reflection pattern that shows both oblique-parallel and sigmoidal clinoforms. The height of clinoforms ranges between $60 \mathrm{~m}$ and $100 \mathrm{~m}$, and dips of the clinoforms commonly vary between $3^{\circ}$ and $10^{\circ}$ (Fig. 77). Clinoformal packages may alternate with units of more or less transparent seismic character (Fig. 78). This part of the succession is interpreted to represent prograding delta lobes with alternating sand-rich and mud-rich units (E.S. Rasmussen et al. 2007; Hansen \& Rasmussen 2008; E.S.
Rasmussen 2009b; Fig. 80, Plates 1-9). On top of each prograding unit, erosional valleys and channels occur and some channels are characterised by having a shingled reflection pattern (E.S. Rasmusssen 2009b). These features were formed by incision and are commonly filled with sand. The shingled reflection pattern is interpreted to represent point bars of meandering river systems (E.S. Rasmussen $e t$ al. 2007; E.S. Rasmussen 2009b). In between these delta lobes, seismic reflectors are parallel, commonly of low amplitude (Fig. 78); this seismic character is considered to reflect the presence of mud-dominated inter-lobe deposits (Hansen \& Rasmussen 2008). In northern and central Jylland, a successive southward migration of delta lobes can be demonstrated (e.g. Plate 2), defining an ascending shoreline trajectory (Fig. 78) indicating progradation during rising sea level (e.g. Helland-Hansen \& Gjelberg 1994). In the northern part of the study area, the Lower Miocene is dominated by a parallel to subparallel reflection pattern capping the clinoforms (Fig. 79). Boreholes penetrating this part of the succession indicate alternating mud- and sand-rich units (Fig. 79). Gravel pits and outcrops around Silkeborg indicate a dominance of braided fluvial systems

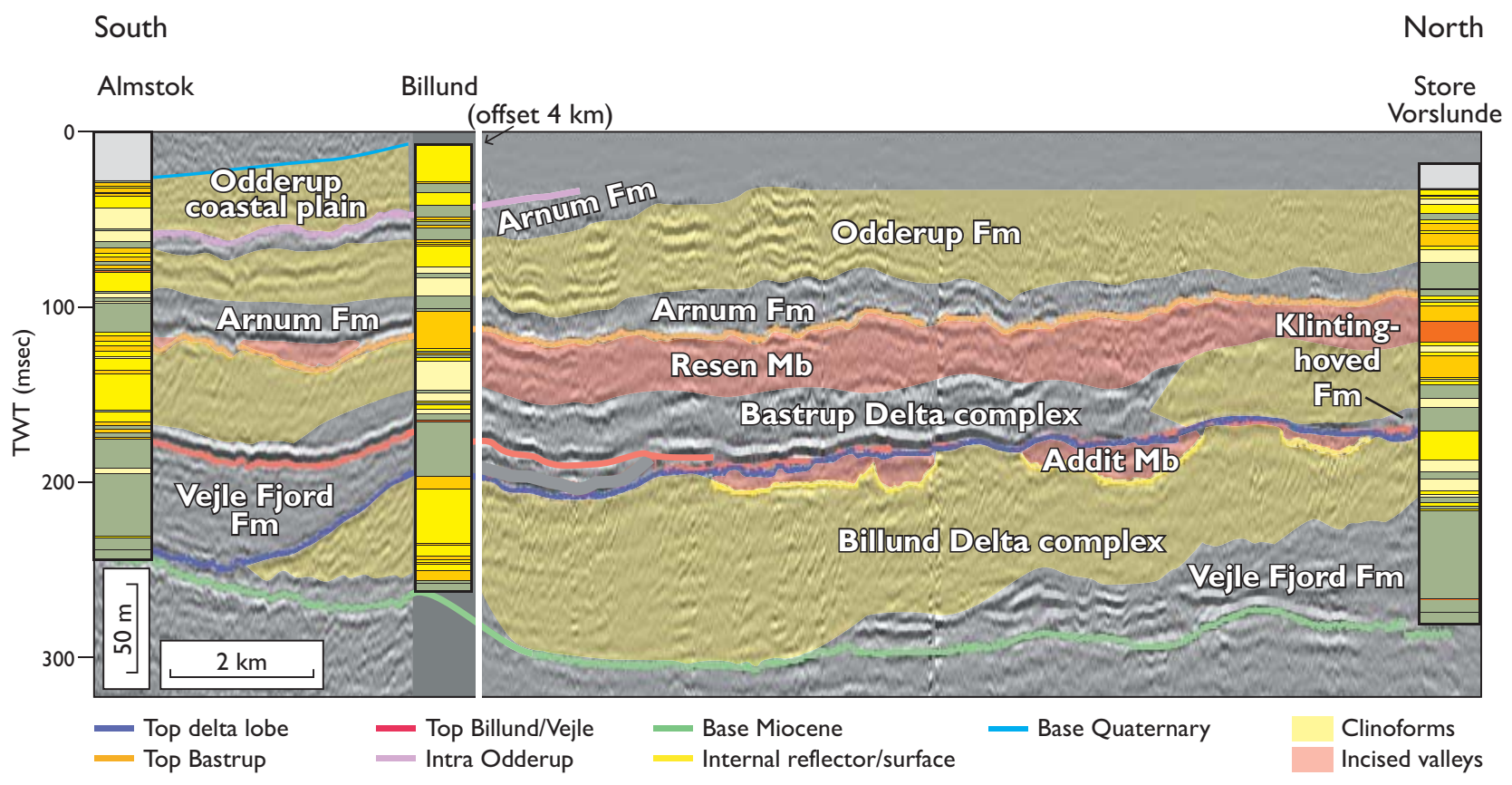

Fig. 77. S-N-trending seismic section tieing the Almstok, Billund and Store Vorslunde boreholes (for location, see Fig. 1). Sand-rich delta lobes characterised by an oblique-parallel reflection pattern are indicated in yellow. Note the alternation of these sand-rich delta deposits and more clay-rich inter-lobe deposits, a characteristic feature of the Vejle Fjord-Billund Formations and the Klintinghoved-Bastrup Formations. The upper part of the section is dominated by a parallel to subparallel reflection pattern which is characteristic of the Arnum-Odderup Formations and indicates a change in sedimentation style. Seismic data courtesy of COWI a/s. 


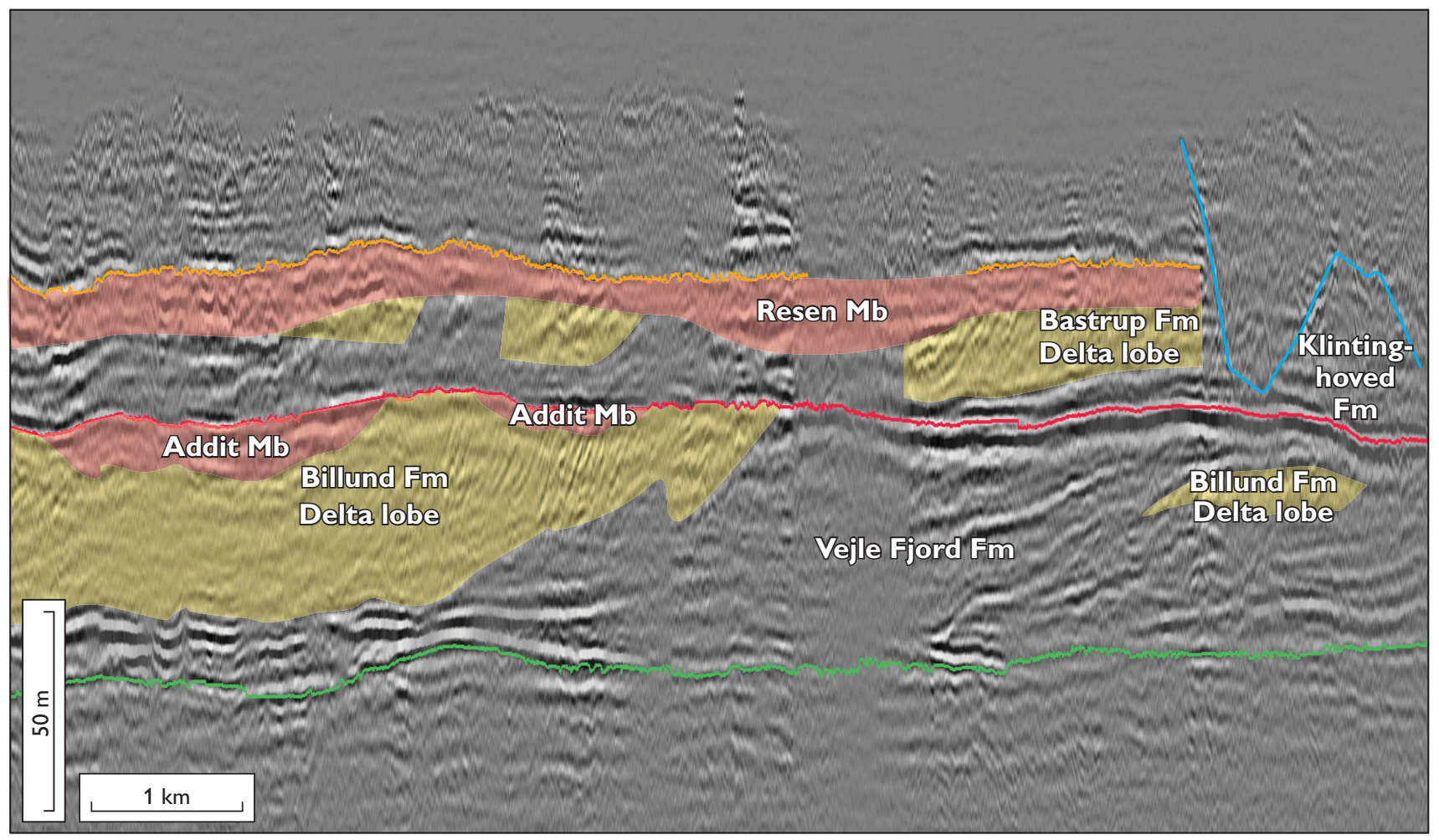

Fig. 78. Detailed seismic section of the Store Vorslunde area (for location, see Fig. 1). Sand-rich parts of the deltas are indicated in yellow, sand-rich fluvial deposits of the Addit and Resen Members are shown in red. Seismic data courtesy of COWI a/s; for legend see Fig. 77.

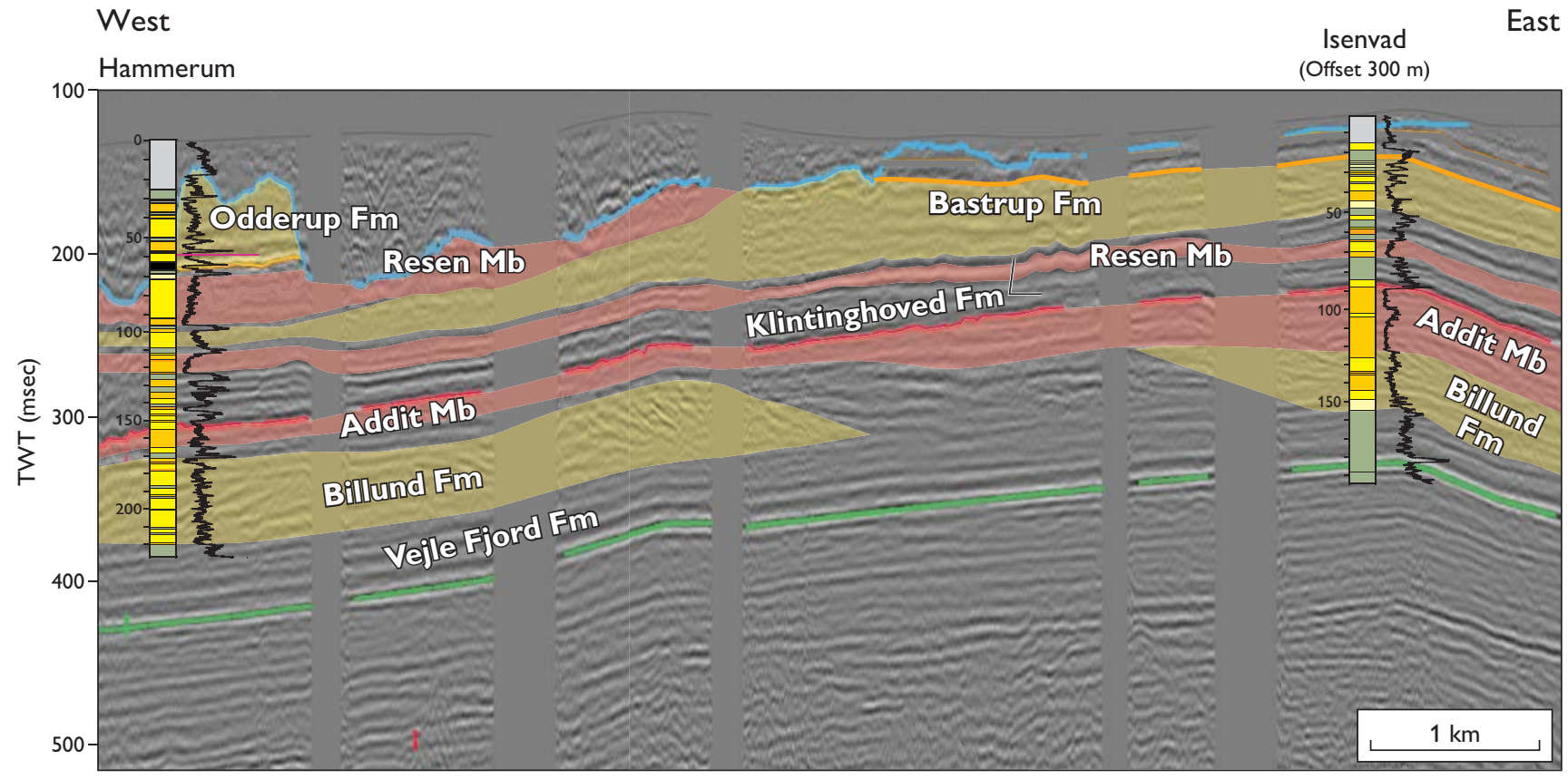

Fig. 79. W-E-striking seismic section at Ikast (for location, see Fig. 1). The section shows a cross-section of the Billund and Bastrup delta systems as indicated by dipping reflectors both towards the west and east. In this area, the fluvial systems of the Addit and Resen Members, shown in red, are particularly well developed. Seismic courtesy of Rambøll a/s; for legend, see Fig. 77). 
in this area (Hansen 1985; Hansen 1995; Jesse 1995; E.S. Rasmussen et al. 2007), and based on subsurface data such braided fluvial systems dominated in northern Jylland and parts of central Jylland from Addit to Hammerum (Plate 6). In a narrow NW-SE-striking belt across central Jylland, the seismic data show an oblique-parallel reflection pattern. This represents progradation during falling sea level (Hansen \& 2008, E.S. Rasmussen 2009b). In southern Jylland, there is a tendency towards a combined aggradationalprogradational stacking pattern (Plate 1), reflecting progradation during rising sea level.
Above these two progradational units of the Billund/Vejle Fjord system and the Klintinghoved/Bastrup system (i.e. above the top Bastrup reflector in Figs 77-79), a parallel to subparallel reflection pattern dominates the Miocene succession (Fig. 77); this correlates with the Arnum and Odderup Formations. The change in seismic character indicates a change in depositional environment from prograding 'Gilbert-type' deltas to aggrading shelf and coastal plain deposits. This is illustrated on correlation panels by progressive outbuilding of the Odderup Formation towards the south-west contemporaneously with the accumulation of the marine Arnum Formation (Fig. 80; Plate 4). 

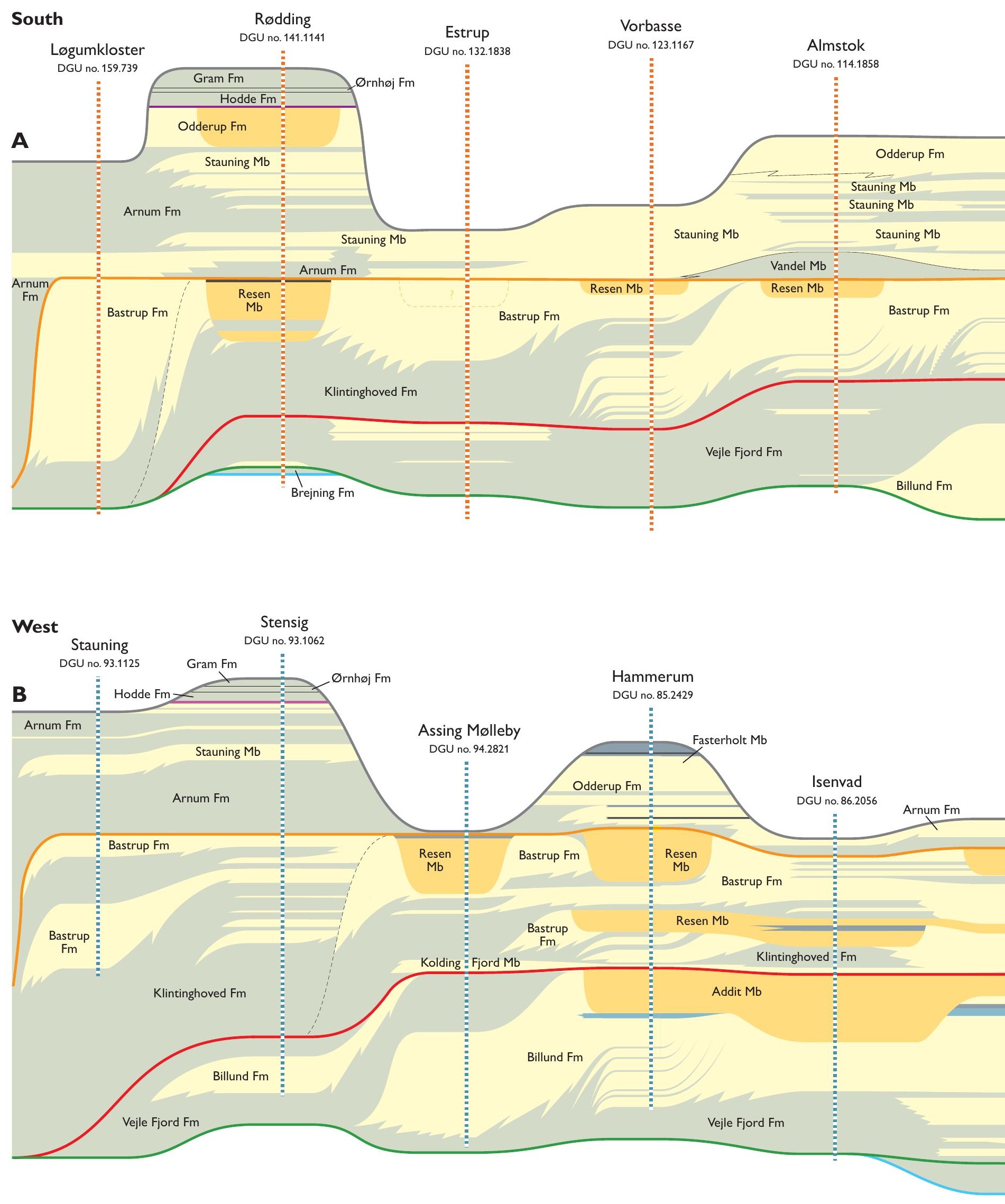


\section{Palaeogeography}

The Late Oligocene was characterised by a warm climate and thus a period with a high sea level (Utscher et al. 2000, 2009; Zachos et al. 2001; Miller et al. 2005; Larsson et al. 2006; Larsson-Lindgren 2009). The North Sea was located in the northern westerly wind belt (Galloway 2002) and consequently the north-eastern part of this sea, which covered present-day Denmark, was dominated by wave processes due to the long fetch across the North Sea (Fig. 2). Most of present-day Denmark was covered by the sea in the Late Oligocene and the deposition of the fully marine Brejning
Formation took place. There is no evidence for the northern position of the coastline at this time, but structural elements such as the Sorgenfrei-Tornquist Zone or the Fennoscandian Shield were probably important features in controlling the location and trend of the shoreline; the position of the coastline is conservatively placed in the fringe area of the Fennoscandian Shield (Fig. 81A). Locally in northern Jylland, the diatomite of the Sydklint Member was formed associated with submarine exposure of Eocene diatomites. Climatic cooling and initial uplift of the
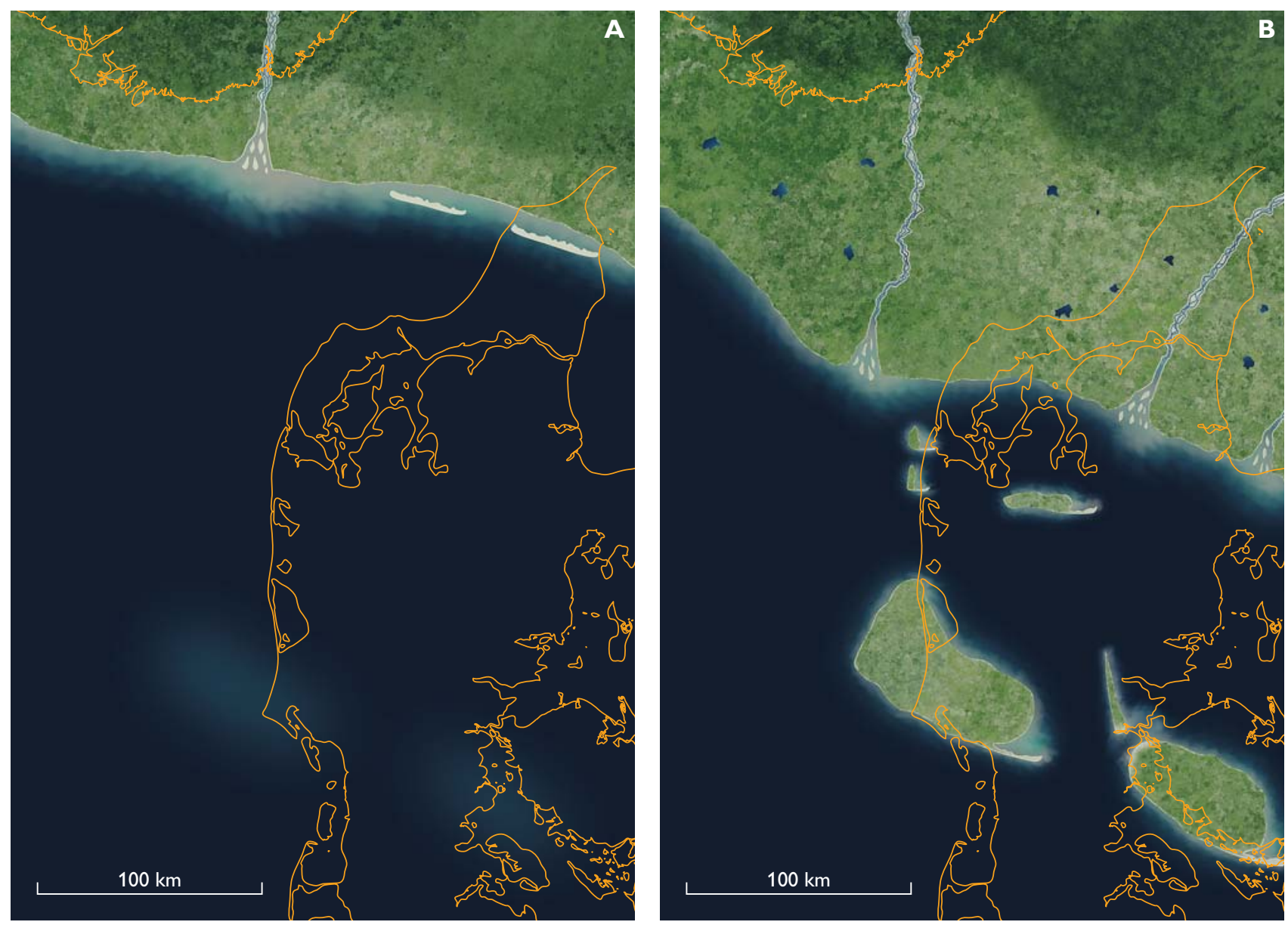

Fig. 81. A: Palaeogeographic reconstruction of the latest Late Oligocene (Brejning Formation). The exact location of the shoreline is uncertain, but most of present-day Jylland was submerged at that time. Water depth in northern Jylland was over $200 \mathrm{~m}$ and extensive formation of glaucony indicates some distance to the shoreline. B: Palaeogeographic reconstruction of the earliest Early Miocene (earliest Aquitanian; Vejle Fjord Formation). Due to Early Miocene inversion (reactivation) of the Ringkøbing-Fyn High and salt structures, a barrier formed between the eastern part of the Norwegian-Danish Basin and the North Sea Basin. This resulted in brackish water conditions north-east of the Ringkøbing-Fyn High. Small spit systems developed east of these structures. The degradation of these spit systems during the Early Miocene transgression resulted in the formation of the Skansebakke Member. 
Norwegian-Danish Basin at the end of the Oligocene (E.S. Rasmussen 2009a) resulted in a fall in relative sea level at the Oligocene-Miocene transition. This led to deposition of the Øksenrade Member which was deposited in shallow water on the Ringkøbing-Fyn High. At Dykær, subaerial conditions prevailed for a period (Rasmussen \& Dybkjær 2005).

The transition from the Oligocene to the Miocene was characterised by a short, but marked sea-level fall associated with ice cap growth on Antarctica (Miller et al. 1996). Coincident with this, inversion of the Norwegian-Danish Basin and reactivation of the Sorgenfrei-Tornquist Zone and the Ringkøbing-Fyn High commenced (E.S. Rasmussen 2009a). This resulted in a marked change in the deposi- tional regime in the eastern North Sea Basin from deposition of dominantly fully marine, clay-rich sediments at the basin floor and toe-of-shelf slope, to sedimentation of coarse-grained, sand-rich, shallow marine, deltaic deposits (Larsen \& Dinesen 1959; L.B. Rasmussen 1961; Spjeldnæs 1975; Friis et al. 1998; Michelsen et al. 1998; E.S. Rasmussen 1996, 2004a, b).

During the earliest Miocene, the palaeogeography was controlled by structural highs and lows (Fig. 81B). Elevated parts of the Ringkøbing-Fyn High formed a barrier across present-day southern Jylland. Salt diapirs within the Norwegian-Danish Basin acted as cores of minor islands. A large silled basin formed north of the Ringkøbing-Fyn High where brackish water conditions prevailed. During
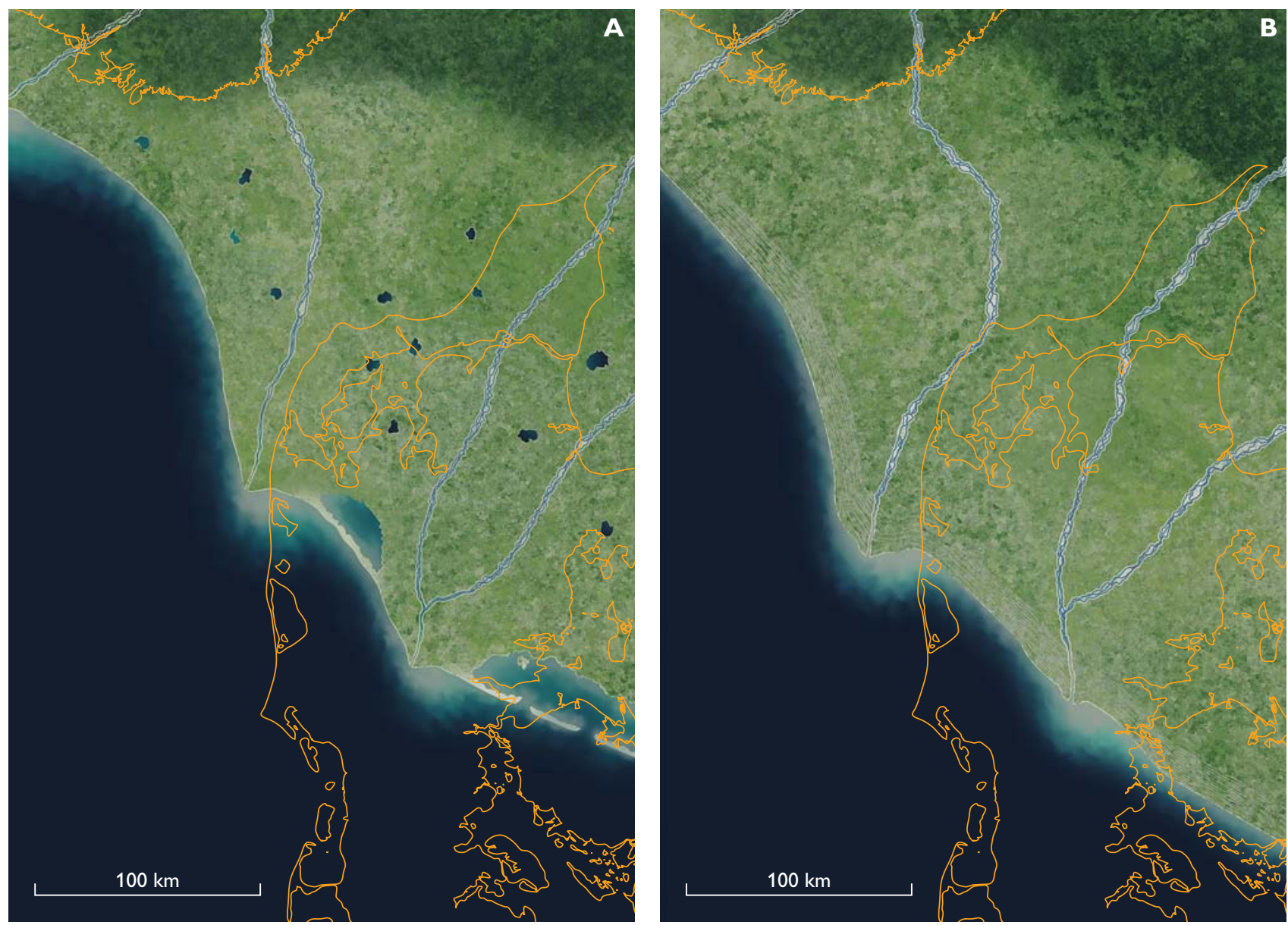

Fig. 82. A: Palaeogeographic reconstruction of the Early Miocene (Aquitanian; Billund and Vejle Fjord Formations). The sea level continued to rise during this phase and flooded the Ringkøbing-Fyn High. Due to high sediment supply to the basin, however, the shoreline prograded southward. This favoured the formation of spit/barrier complexes south-east of the main delta lobes; represented by the Hvidbjerg Member of the Billund Formation. The river system during the Early Miocene was dominantly braided in character. B: Palaeogeographic reconstruction of the Early Miocene (late Aquitanian; Billund Formation). During this period, relative sea level fell and progradation of the shoreline is reflected by amalgamation of beach ridges along the coast. Distinct incision and formation of broad valleys commenced at the same time. 
the lowstand of sea level, sands were transported along the structures and deposited as spits and barrier islands east of the structures (Fig. 81B). In this brackish water basin, the lower part of the Vejle Fjord Formation was deposited. A subsequent rise of sea level in the early Aquitanian resulted in flooding of the Ringkøbing-Fyn High. This led to degradation of the barrier complexes and deposition of the Skansebakke Member. At the time of maximum flooding, the shoreline withdrew to a position north of Århus in the east and near Thisted in the north-west. The high sediment supply to the North Sea Basin, however, resulted in progradation of sand-rich delta complexes from the north and north-east, as recorded by the Billund Formation (Fig. $82 \mathrm{~A})$. The sediments were probably conveyed through three major river systems (Olivarius 2009). The western river was probably connected to the Setesdal valley in presentday Norway and was the source for the sediments deposited in the delta located off the present west coast of Denmark, the so-called Ringkøbing lobe (Hansen \& Rasmussen 2008). The central river was sourced from the north, probably from the southern part of present-day Norway and the northern part of present-day central western Sweden. The eastern river drained the area covered by the present-day central Sweden. The central and eastern river system merged in central Jylland and resulted in the deposition of the Brande lobe of the Billund Formation (Hansen \& Rasmussen 2008). The river systems were braided and their deposits constitute the Addit Member. On entering the
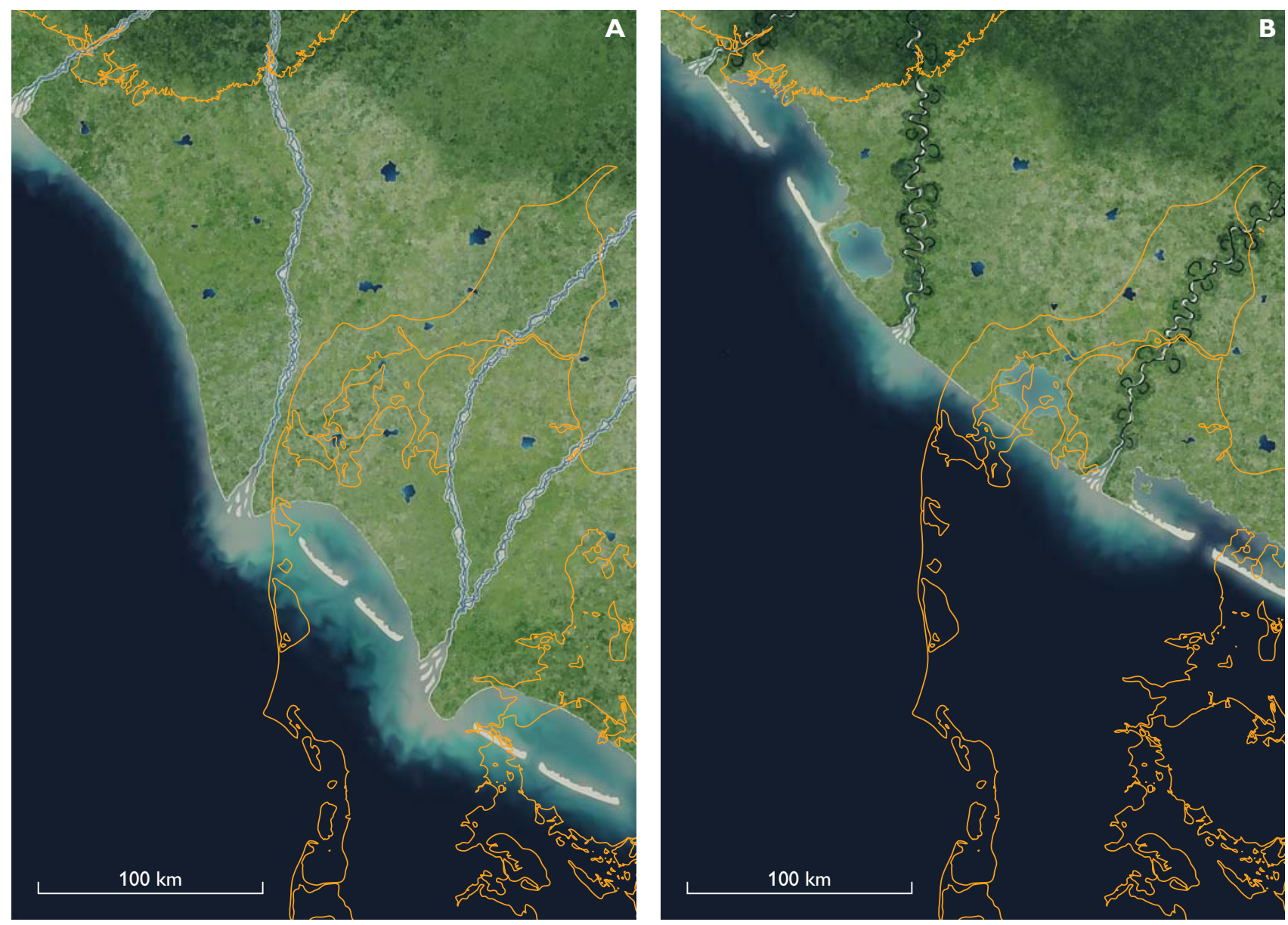

Fig. 83. A: Palaeogeographic reconstruction of the Early Miocene (early Burdigalian; Klintinghoved Formation and Kolding Fjord Member). Global climatic warming resulted in a relative rise in sea level. The shoreline was characterised by estuaries and associated barrier complexes and the accumulation of braided fluvial deposits in incised valleys. B: Palaeogeographic reconstruction of the Early Miocene (early Burdigalian; Klintinghoved Formation). During the most widespread flooding in the early Burdigalian, most of western and central Jylland was covered by the sea and the clay-rich Klintinghoved Formation was deposited. 
sea, the sands were deposited in wave-dominated deltas (Rasmussen \& Dybkjær 2005; Hansen \& Rasmussen 2008). Some of the sand at the delta mouth was reworked and transported eastward by longshore currents to be deposited as spit and barrier complexes of the Hvidbjerg Member (Fig. 82A). Development of lagoonal environments was common during this time. Due to a global climatic deterioration in the late Aquitanian (Zachos et al. 2001), sea level began to fall and the delta complexes were forced south-westward; deposition of a coastline characterised by amalgamated beach ridges took place (Fig. 82B).

A resumed transgression occurred at the beginning of the Burdigalian. This transgression was the result of a global warming (Zachos et al. 2001). According to T. Utescher (per- sonal communication 2008), the average air temperature rose $2^{\circ} \mathrm{C}$. Widespread barrier-island complexes formed east of the main delta systems due to strong erosion of the main delta and eastward transport of erosional materials. These barrier-island complexes correspond to the Kolding Fjord Member (Fig. 83A). During maximum flooding of the sea and associated with the progradation of the succeeding delta complex, mud was deposited in the Danish area. This constitutes the Klintinghoved Formation (Fig. 83B). The succeeding delta complex, the Bastrup Formation, prograded south-westward (Fig. 84A) and periodically this progradation occurred during a sea-level fall. The coastline was dominated by beach ridges (Fig. 84B). In midBurdigalian times, the delta complexes of the Bastrup
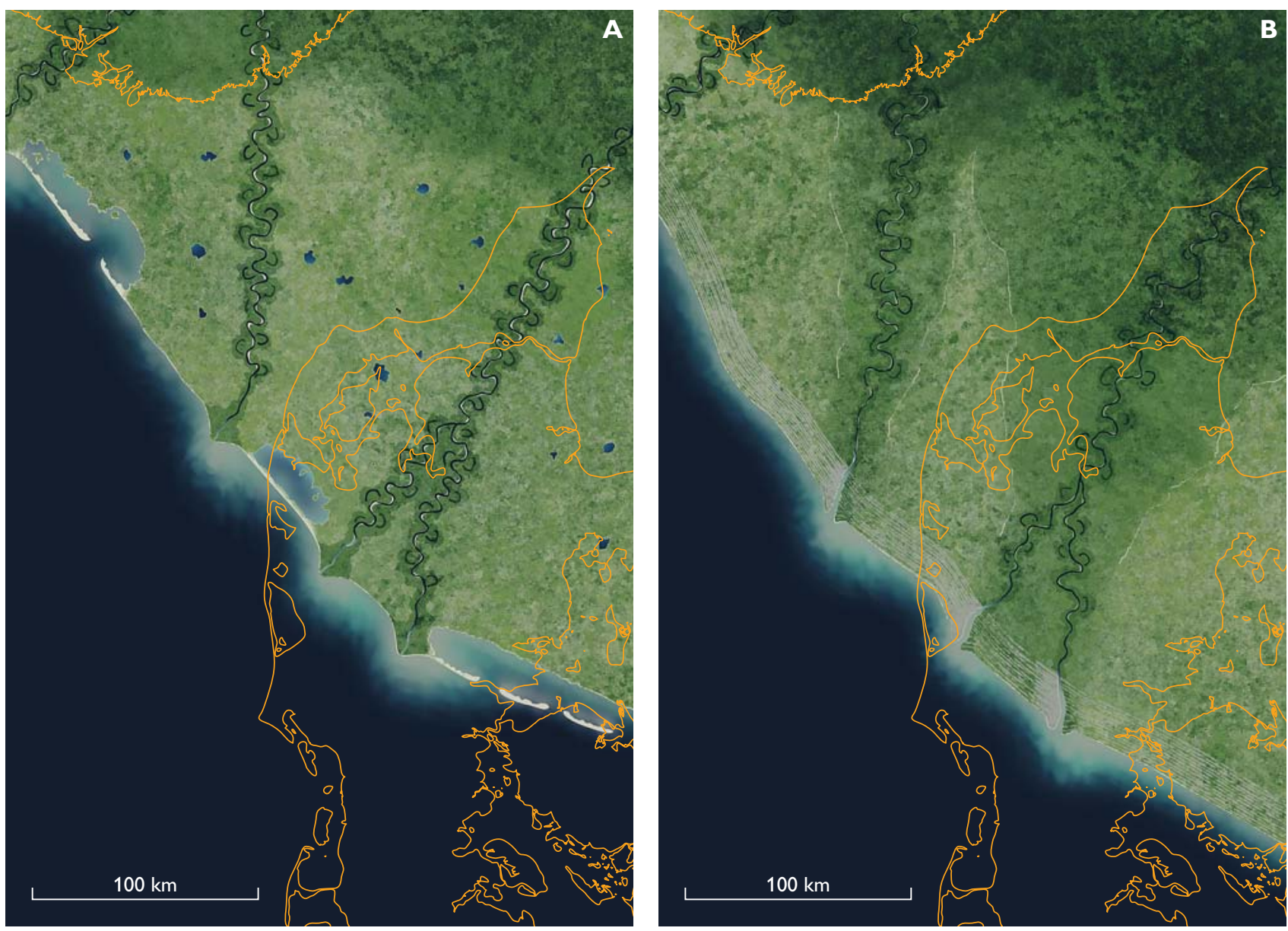

Fig. 84. A: Palaeogeographic reconstruction of the Early Miocene (early Burdigalian; Bastrup Formation). Progradation occurred during rising relative sea level which formed optimal conditions for a shoreline dominated by lagoons and barrier islands. The fluvial system was dominated by meandering river systems. B: Palaeogeographic reconstruction of the Early Miocene (Burdigalian; Bastrup Formation). During this period, relative sea level fell and the prograding shoreline was characterised by amalgamation of beach ridges parallel to the coast. Distinct incision on land and formation of broad valleys commenced at the same time. 
Formation reached the southern part of Denmark (Fig. 85A). During sedimentation of the Bastrup Formation, the fluvial regime changed character, to be dominated by meandering rivers, especially in the latter phase of progradation. Sand deposits of these rivers are referred to the Resen Member.

A distinct global climatic warming, the 'Mid Miocene climatic optimum', occurred at the end of the Early Miocene (late Burdigalian) (Zachos et al. 2001). This resulted in a sea-level rise and renewed transgression. The mud laid down during this transgression and in front of the succeeding prograding coastline is represented by the Arnum Formation (Fig. 85B). At the time of maximum flooding, the coastline was located across the northern part of pre- sent-day north-west Jylland and continued south-eastwards through central Jylland. Despite a subtropical climate (Friis 1975), and hence globally high sea levels during the latest part of Early and early Middle Miocene, progradation resumed (Fig. 86A). This was due to tectonism and uplift of the hinterland and consequently increased sediment supply to the North Sea Basin (E.S. Rasmussen 2004b). Sand of the prograding coastline is represented by the Odderup Formation (Fig. 86B). Fine-grained storm-sand layers deposited in front of the coastline are included in the Stauning Member. As a consequence of the prograding coastline of the Odderup Formation and coincident rising sea level due to the warmer climate, conditions for brown coal formation were optimal. A preliminary study ( $\mathrm{T}$.
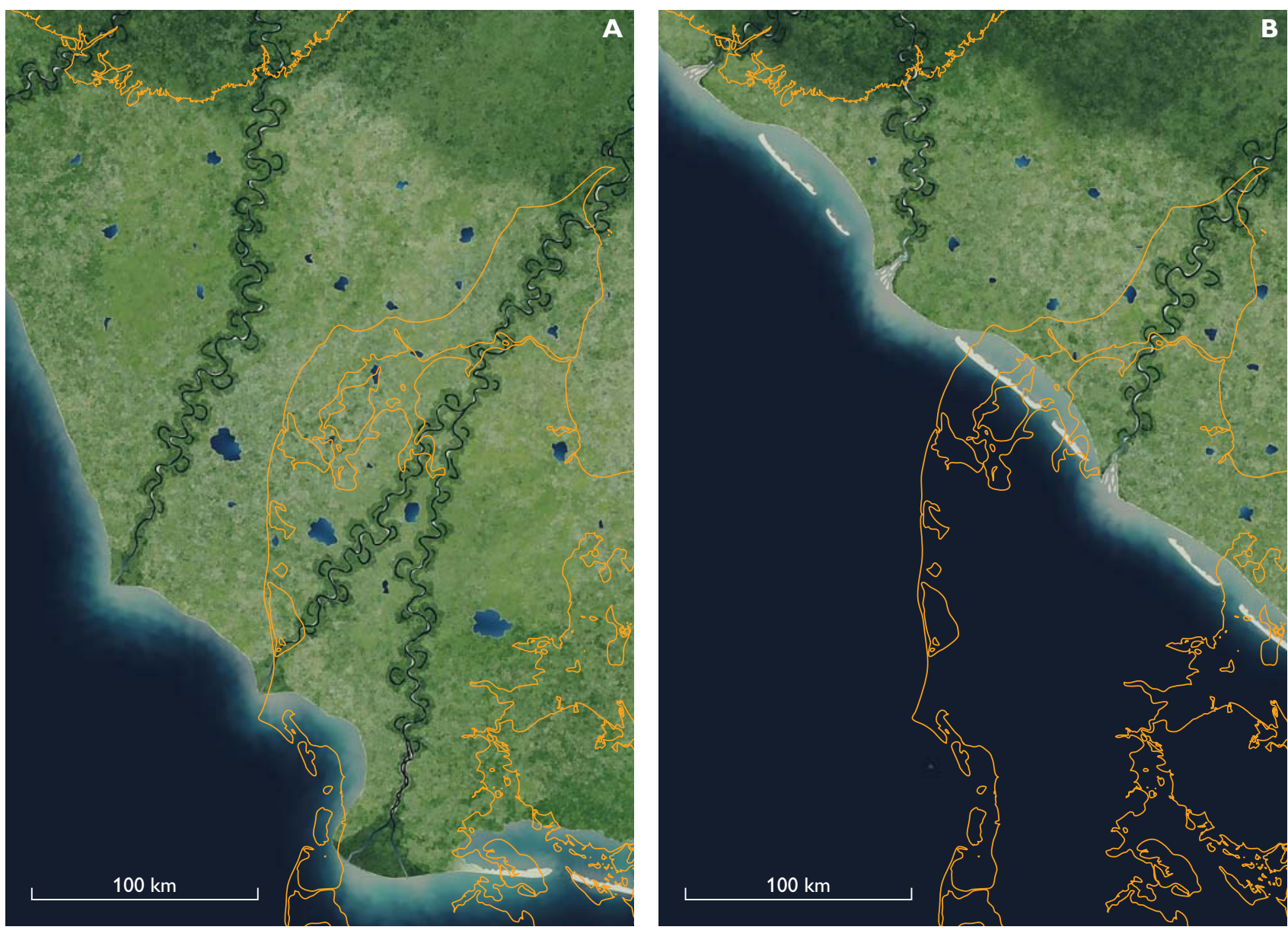

Fig. 85. A: Palaeogeographic reconstruction of the Early Miocene (Burdigalian; Bastrup Formation) when most of Jylland was land; progradation took place during rising sea level. B: Palaeogeographic reconstruction of the late Early Miocene (late Burdigalian; Arnum Formation). The shoreline was located across the northern part of Jylland at the time of maximum flooding. 
Utescher, personal communication 2009) indicated that widespread coal formation was also associated with increased precipitation in the area. The coal was formed on the coastal plain especially adjacent to pre-existing faults (Koch 1989) and predominantly north of the Ringkøbing-Fyn High. These widespread coal layers are referred to the Fasterholt Member (Koch 1989).

Due to the overall rising sea level during the Mid Miocene climatic optimum, and partly also due to 'auto retreat' (see Muto \& Steel 2002), a major transgression occurred in the middle Langhian (early Middle Miocene). The transgression was further amplified by increased subsidence of the North Sea Basin during the Middle and Late Miocene (Koch 1989; Michelsen et al 1998; Clausen et al. 1999; E.S.
Rasmussen 2004b; E.S. Rasmussen et al. 2005). Mud-rich sediments of the Hodde Formation were deposited during this transgression. There is no evidence of the formation of barrier-island complexes during the transgression which suggests a very rapid flooding of the low relief landscape represented by the coal-rich Odderup Formation. Despite major global climatic deterioration (cooling) in the early Serravallian (Middle Miocene; Zachos et al. 2001), flooding of this part of the North Sea Basin continued as a consequence of the accelerating subsidence of the basin. During the most widespread flooding of the area, glaucony-rich sediments of the Ørnhøj Formation accumulated, indicating a long distance to the coastline. The location of the coastline during this maximum transgression is uncertain.
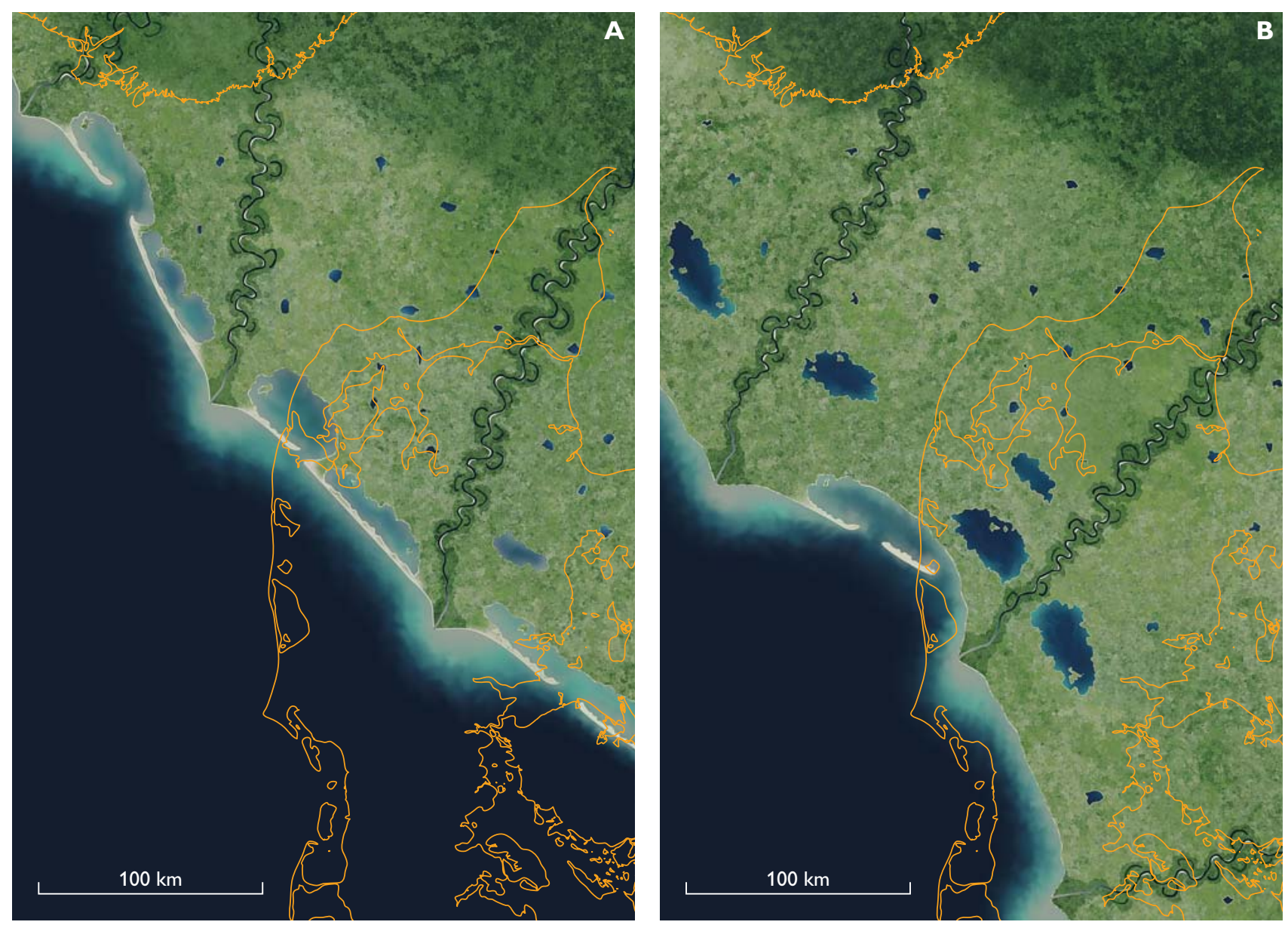

Fig. 86. A: Palaeogeographic reconstruction of the late Early Miocene (late Burdigalian; Odderup Formation). At this time, the climate became subtropical and the global sea level continued to rise. High sediment supply, however, forced the shoreline to prograde. These conditions favoured formation of lagoons and swamp lakes which were optimal for the formation of coal-rich deposits. B: Palaeogeographic reconstruction of the early Middle Miocene (early Langhian; Odderup Formation). During the maximum regression of the shoreline, most of Jylland was land and only the south-western part was submerged. Lagoonal and swamp conditions prevailed north of the Ringkøbing-Fyn High, probably favoured by increased subsidence in this area. 
Boreholes in central Jylland do not indicate any influx of coarse-grained siliciclastic deposits, so at a minimum, the coastline was displaced to the southern boundary of the Fennoscandian Shield (Fig. 87A). Parts of the shield may, however, have been flooded during the highest rate of relative sea-level rise. Coincident with the subsidence of the North Sea Basin, the Norwegian mainland was uplifted (Løseth \& Henriksen 2005; Rundberg \& Eidvin 2005; Eidvin \& Rundberg 2007; E.S. Rasmussen et al. 2008). This resulted in enhanced sediment supply to the basin where progradation took place. Mud of the Gram Formation was deposited in an open shelf environment (Fig. 87B). Thin storm-sand layers are intercalated in the upper Gram For- mation indicating an approaching coastline (Rasmussen $\&$ Larsen 1989). Near the end of the Tortonian (Late Miocene), shoreface sediments of the Marbæk Formation were deposited in the central-western part of present-day Denmark (Fig. 88).

Progradation of the coastline continued through the Late Miocene and a delta/coastline was formed in the central part of the Central Graben area (Rasmussen 2005; Møller et al. 2009). The termination of the Miocene was characterised by a sea-level fall of $c .90 \mathrm{~m}$, which is indicated by deep incision of equivalent strata in the offshore Cenozoic record of Denmark (Møller et al. 2009).
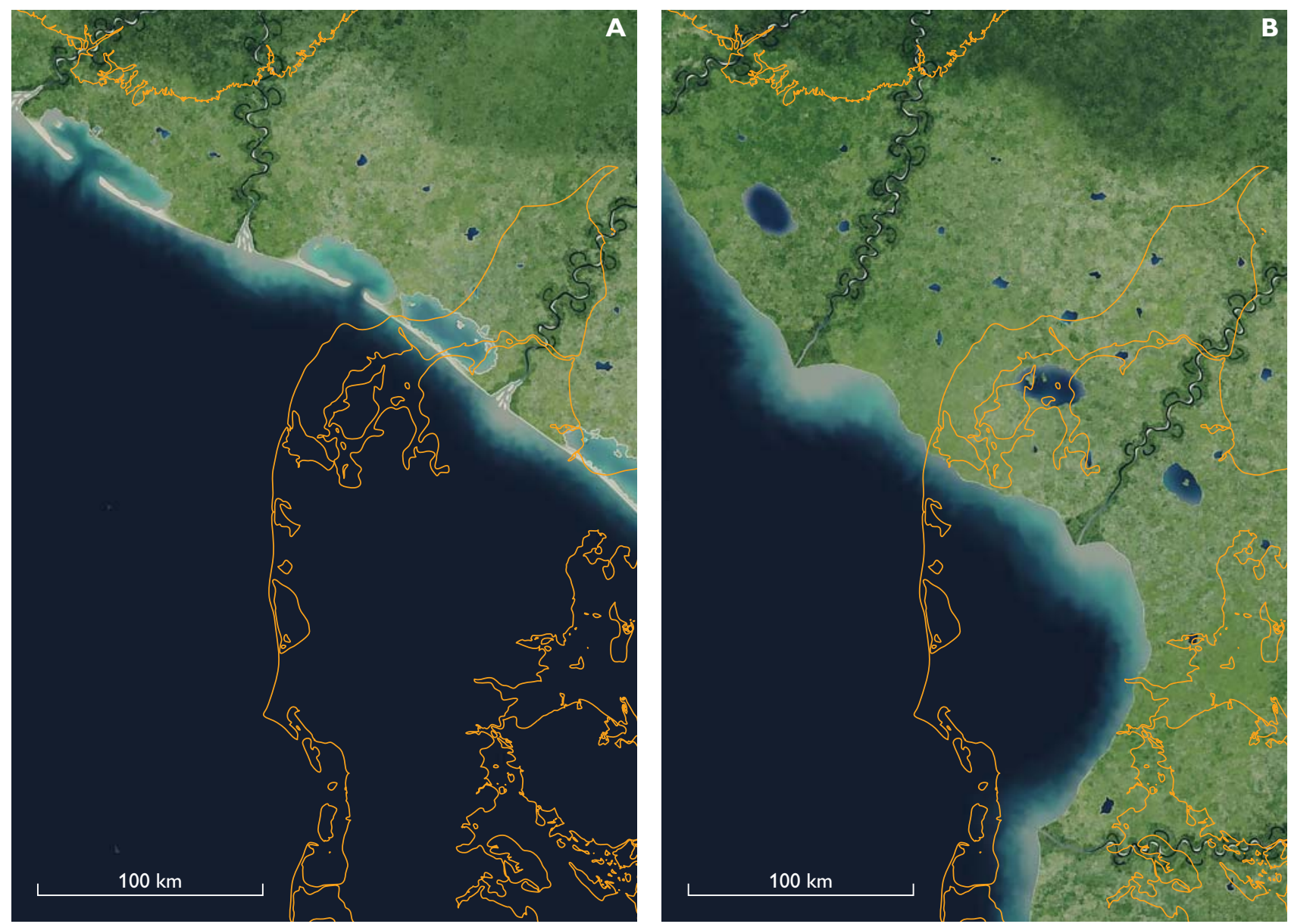

Fig. 87. A: Palaeogeographic reconstruction of the Middle Miocene (Serravallian; Ørnhøj Formation). Despite climatic deterioration in the Middle Miocene, most of Jylland was flooded and the shoreline was located in the northern part of Jylland. Due to very low sedimentation rates, optimal conditions existed for the formation of glaucony. B: Palaeogeographic reconstruction of the Late Miocene (Tortonian; Gram Formation). In the latest part of the Miocene, uplift of Scandinavia and the Alpine mountains resulted in extremely high sediment supply into the North Sea Basin. This led to marked progradation from both the north and south. 


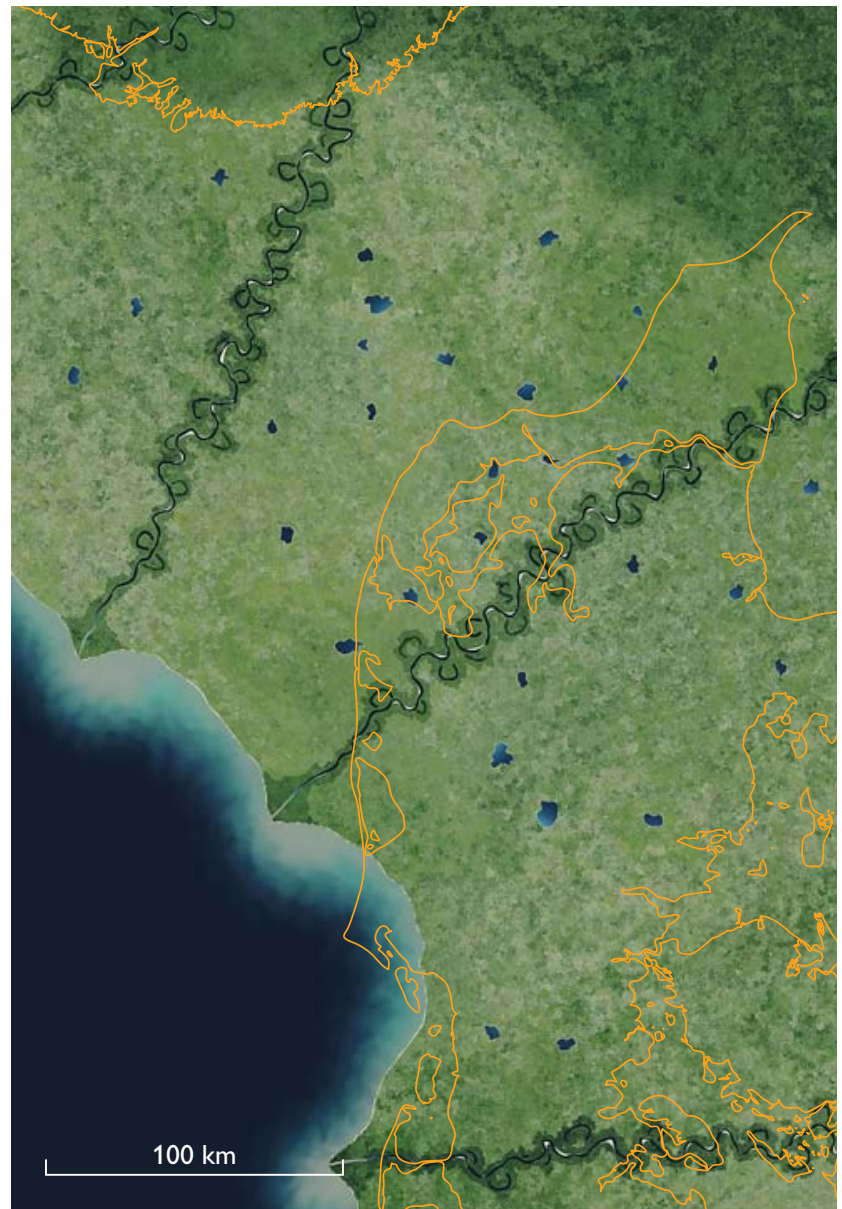

Fig. 88. Palaeogeographic reconstruction of the Late Miocene (Tortonian; Marbæk Formation). The marked progradation of the shoreline during the Late Miocene resulted in subaerial conditions over most of Jylland and deposition of shoreface deposits only in the extreme western part of Jylland. At the end of the Miocene, the shoreline was located c. $250 \mathrm{~km}$ west of the present-day west coast of Jylland.

\section{Acknowledgements}

This project would not have been possible without the enthusiastic participation of the geologists working in the municipalities of Vejle, Ringkøbing, Ribe, Århus and Sønderjylland (subsequently restructured into MC Ribe, MC Ringkøbing, MC Århus and Region Syddanmark). The fundamental sedimentological and stratigraphic research on which this study is based was supported financially by the Carlsberg Foundation. Statens Naturvidenskabelige Forskningsråd (Danish Natural Science Research Council) generously supported the drilling of the cored borehole at Sdr. Vium. Keld Rømer Rasmussen kindly provided the gamma-ray log from the Addit gravel-pit borehole. Tibor Czako and K. Ingemann Schnetler are thanked for fruitful discussions on Miocene geology. Claus HeilmannClausen is thanked for guidance to the localities in the Limfjorden area. The authors thank Claus HeilmannClausen and Dan Evans for thorough and constructive reviews; Claus Heilmann-Clausen also provided data and descriptions from the Sydklint Member. 


\section{References}

Asgaard, U. \& Bromley, R.G. 1974: Sporfossiler fra den Mellem Miocæne transgression i Søby-Fasterholt området. Dansk Geologisk Forening Årskrift 1973, 11-19.

Bendix-Almgreen, S.E. 1983: Carcharodon megalodon from the Upper Miocene of Denmark, with comments on elasmobranch tooth enameloid: coronoïn. Bulletin of the Geological Society of Denmark 32, 1-32.

Bertelsen, F. 1978: The Upper Triassic - Lower Jurassic Vinding and Gassum Formations of the Norwegian-Danish Basin. Danmarks Geologiske Undersøgelse Serie B 3, 26 pp.

Berthelsen, A. 1992: Mobile Europe. In: Blundell, D., Freeman, R. \& Mueller, St. (eds): A continent revealed: the European geotraverse, 11-32. Cambridge: Cambridge University Press.

Beyrich, E. 1853: Die Conchylien des norddeutschen Tertiärgebirges. Zeitschrift der Deutsche Geologisches Gesellschaft 5, 273-358.

Bøggild, O.B. 1918: Den vulkanske Aske i Moleret samt en Oversigt over Danmarks ældre Tertiærbjærgarter. Danmarks Geologiske Undersøgelse II. Række 33, 159 pp. + atlas.

Bromley, R.G. 1996: Trace fossils: biology, taphonomy and applications. 2nd edition, 361 pp. London: Chapman \& Hall.

Buchardt, B. 1978: Oxygene isotope palaeotemperatures from the Tertiary period in the North Sea area. Nature 275, 121-123.

Buchardt-Larsen, B. \& Heilmann-Clausen, C. 1988: The Danish subbasin, southern Jylland. In: Vinken R. (compiler): The northwest European Tertiary Basin: results of the International Geological Correlation Program No 124. Geologisches Jahrbuch 100, 83-91.

Bukry, D. 1981: Synthesis of silicoflagellate stratigraphy for Maestrichtian to Quaternary marine sediments. In: Warme, T.E., Douglas, R.C. \& Winterer, E.L. (eds): The Deep Sea Drilling Project: a decade of progress. Society of Economic Paleontologists and Mineralogists (SEPM) Special Publication 32, 433-444.

Christensen, E.F. 1975: The Søby-flora: fossil plants from the Middle Miocene delta deposits of the Søby-Fasterholt area, central Jutland, Denmark. Part I. Danmarks Geologiske Undersøgelse II. Række 103, 41 pp.

Christensen, E.F. 1976: The Søby-flora: fossil plants from the deltaic deposits of the Søby-Fasterholt area, central Jutland, Denmark. Part II. Danmarks Geologiske Undersøgelse II. Række 108, 49 pp.

Christensen, L. \& Ulleberg, K. 1973: Sedimentology and micropalaeontology of the Middle Oligocene sequence at Sofienlund. Bulletin of the Geological Society of Denmark 22, 283-305.

Clausen, O.R., Gregersen, U., Michelsen, O. \& Sørensen, J.C. 1999: Factors controlling the Cenozoic sequence development in the eastern parts of the North Sea. Journal of the Geological Society (London) 156, 809-816.

Dalgas, E. 1868: Geographiske Billeder fra Heden 2, 125 pp. København: Det Danske Hedeselskab.
Danielsen, M., Michelsen, O. \& Clausen, O.R. 1997: Oligocene sequence stratigraphy and basin development in the Danish sector of the North Sea based on log interpretations. Marine and Petroleum Geology 14, 931-950.

Deegan, C.E. \& Schull, B.J. (compilers) 1977: A standard lithostratigraphic nomenclature for the central and northern North Sea. Institute of Geological Science Report 77/25, 36 pp. London: Her Majesty's Stationary Office.

Dinesen, B. 1976: Geochemical properties of the marine Younger Miocene at Gram, SW Jutland. Danmarks Geologiske Undersøgelse Årbog 1975, 5-29.

Doré, A.G., Lundin, E.R., Kusznir, N.J. \& Pascal, C. 2008: Potential mechanisms for the genesis of Cenozoic domal structures on the NE Atlantic margin: pros, cons and some new ideas. In: Johnson, H. et al. (eds): The nature and origin of compression in passive margins. Geological Society Special Publication (London) 306, 1-26.

Dybkjær, K. 2004a: Dinocyst stratigraphy and palynofacies studies used for refining a sequence stratigraphic model - uppermost Oligocene to Lower Miocene, Jylland, Denmark. Review of Palaeobotany and Palynology 131, 201-249.

Dybkjær, K. 2004b: Morphological and abundance variations in Homotryblium-cyst assemblages related to depositional environments; uppermost Oligocene - Lower Miocene, Jylland, Denmark. Palaeogeography, Palaeoclimatology, Palaeoecology 206, 41-58.

Dybkjær, K. \& Piasecki, S. 2008: A new Neogene biostratigraphy for Denmark. Geological Survey of Denmark and Greenland Bulletin 15, 29-32.

Dybkjær, K. \& Piasecki, S. 2010: Neogene dinocyst zonation in the eastern North Sea Basin, Denmark. Review of Palaeobotany and Palynology 161, 1-29.

Dybkjær, K. \& Rasmussen E.S. 2000: Palynological dating of the Oligocene-Miocene successions in the Lille Bælt area, Denmark. Bulletin of the Geological Society of Denmark 47, 87-103.

Dybkjær, K. \& Rasmussen, E.S. 2007: Organic-walled dinoflagellate cyst stratigraphy in an expanded Oligocene-Miocene boundary section in the eastern North Sea Basin (Frida-1 well, Denmark) and correlation from basinal to marginal areas. Journal of Micropalaeontology 26, 1-17.

Eder, V.G., Martín-Algarra, A., Sánchez-Navas, A., Zanin, Y.N., Zamirailova, G. \& Lebedev, Y.N. 2007: Depositional controls on glaucony texture and composition, Upper Jurassic, West Siberian Basin. Sedimentology 54, 1365-1387.

Eidvin, T. \& Rundberg, Y. 2007: Post-Eocene strata of the southern Viking Graben, northern North Sea; integrated biostratigraphic, strontium isotopic and lithostratigraphic study. Norwegian Journal of Geology 87, 391-450.

Eriksen, K. 1937: En foreløbig Meddelelse om Tertiæret ved Brejning paa Sydsiden af Vejle Fjord. Meddelelser fra Dansk Geologisk Forening 9, 137-150. 
Faleide, J.I., Kyrkjebø, R., Kjennerud, T., Gabrielsen, R.H., Jordt, H., Fanavoll, S. \& Bjerke, M.D. 2002: Tectonic impact on sedimentary processes during Cenozoic evolution of the northern North Sea and surrounding areas. In: Doré, A.G. et al. (eds): Exhumation of the North Atlantic margin: timing, mechanism and implications for petroleum exploration. Geological Society Special Publication (London) 196, 235-269.

Forchhammer, J.G. 1835: Danmarks geognostiske Forhold, forsaavidt som de ere afhængige af Dannelser, der ere sluttede fremstillede i et Indbydelsesskrift til Reformationsfesten den 14de November 1835, 112 pp. København: Kongelig og UniversitetsBogtrykker J.H. Schultz.

Friis, E.M. 1975: Climatic implications of microcarpological analyses of the Miocene Fasterholt flora, Denmark. Bulletin of the Geological Society of Denmark 24, 179-191.

Friis, E.M. 1979: The Damgaard flora: a new Middle Miocene flora from Denmark. Bulletin of the Geological Society of Denmark 27, 117-142.

Friis, H. 1976: Weathering of a Neogene fluviatile fining-upwards sequence at Voervadsbro, Denmark. Bulletin of the Geological Society of Denmark 25, 99-105.

Friis, H. 1994: Lithostratigraphy and sedimentary petrography of the Oligocene sediments from the Harre borehole, Denmark. Aarhus Geoscience 1, 35-43. Aarhus, Denmark: University of Aarhus.

Friis, H. 1995: Neogene aflejringer. In: Nielsen, O.B. (ed.): Danmarks geologi fra Kridt til i dag. Aarhus Geokompendier 1, 115-128. Aarhus, Danmark: Aarhus Universitet.

Friis, H., Mikkelsen, J. \& Sandersen, P. 1998: Depositional environment of the Vejle Fjord Formation of the Upper OligoceneLower Miocene of Denmark: a barrier island/barrier-protected depositional complex. Sedimentary Geology 17, 221-244.

Gabrielsen, R.H., Faleide, J.I., Pascal, C., Braathen, A., Nystuen, J.P., Etzelmuller, B. \& O’Donnell, S. 2010: Latest Caledonian to Present tectonomorphogical development of southern Norway. Marine and Petroleum Geology 27, 709-723.

Galloway, W.E. 2002: Paleogeographic setting and depositional architecture of a sand-dominated shelf depositional system, Miocene Utsira Formation, North Sea. Journal of Sedimentary Research 72, 447-490.

Garboe, A. 1961: Geologiens historie i Danmark I \& II, 283 pp., 522 pp. København: C.A. Reitzels Forlag.

Gradstein, F.M. et al. 2004: A geological time scale, 610 pp. Cambridge: Cambridge University Press.

Gravesen, P. 1990: Oligozän in Ost-Jütland, 2. Teil. Fossilien 3/90, $117-120$.

Håkansson, E. \& Pedersen, S.A.S. 1992: Geologisk kort over den danske undergrund. Varv [special publication]. København: Tidsskriftet Varv.

Hansen, H.C. 1995: Tertiary fluvial deposits of Jylland, Addit area. In: Michelsen O. (ed.): Proceedings of the 2 nd symposium on marine geology: geology of the North Sea and Skagerrak, Aarhus Universitet, 1993. Danmarks Geologiske Undersøgelse Serie C 12, 39-51.
Hansen, J.Ø. 1985: En lithofacies undersøgelse af nogle kvartssandforekomster i Midtjylland, 126 pp. Unpublished MSc thesis, Aarhus Universitet, Danmark.

Hansen, J.P.V. \& Rasmussen, E.S. 2008: Structural, sedimentologic, and sea-level controls on sand distribution in a steep-clinoform asymmetric wave-dominated delta: Miocene Billund sand, eastern Danish North Sea and Jylland. Journal of Sedimentary Research 78, 130-146.

Hardt, T., Holtar, E., Isaksen, D., Kyllingstad, G., Lervik, K.S., Lycke, A.S. \& Tonstad, K. 1989: Revised Tertiary lithostratigraphic nomenclature for the Norwegian North Sea. In: Isaksen, D. \& Tonstad, K. (eds): A revised Cretaceous and Tertiary lithostratigraphic nomenclature for the Norwegian North Sea. Norwegian Petroleum Directorate (NDP) Bulletin 5, 35-55.

Hartz, N. 1909: Bidrag til Danmarks tertiære og diluviale Flora, 292 pp. Tekst og atlas.

Harzhauser, M. \& Piller, W.E. 2007: Benchmark data of a changing sea - Palaeogeography, Palaeobiogeography and events in the central Paratethys during the Miocene. Palaeogeography, Palaeoclimatology, Palaeoecology 253, 8-31.

Heilmann-Clausen, C. 1982: The Paleocene-Eocene boundary in Denmark. Newsletters on Stratigraphy 11, 55-63.

Heilmann-Clausen, C. 1995: Palæogene aflejringer over Danskekalken. In: Nielsen, O.B. (ed.): Danmarks geologi fra Kridt til i dag. Aarhus Geokompendier 1, 69-114. Aarhus: Geologisk Institut, Aarhus Universitet.

Heilmann-Clausen, C. 1997: How one diatomite led to the development of another diatomite - the Oligocene section at Silstrup, NW Denmark. Tertiary Research 18, 31-34.

Heilmann-Clausen, C. \& Surlyk, F. 2006: Koralrev og lerhav. In: Larsen, G. (ed.): Naturen i Danmark: Geologien, 181-226. København: Gyldendal.

Heilmann-Clausen, C., Nielsen, O.B. \& Gersner, F. 1985: Lithostratigraphy and depositional environments in the upper Palaeocene and Eocene of Denmark. Bulletin of the Geological Society of Denmark 33, 287-323.

Helland-Hansen, W. \& Gjelberg, J.G. 1994: Conceptual basis and variability in sequence stratigraphy: a different perspective. Sedimentary Geology 92, 31-52.

Heller, E. 1960: Keld Milthers' arbejde med brunkulseftersøgningen. Meddelelser fra Dansk Geologisk Forening 14, 447-453.

Hinsch, W. 1990: Subdivision and palaeogeography of the Gramian and Syltian stages (Late Miocene) in Schleswig-Holstein and Wursten (NW Germany). Tertiary Research 11(2-4), 159-177.

Hoch, E. 2008: Hvaler for 8 millioner år siden. In: Adriansen, I. et al. (eds): Under fælles hat. Årbog for Museum Sønderjylland, 41-56. Haderslev: Museum Sønderjylland.

Japsen, P. 1993: Influence of lithology and Neogene uplift on seismic velocities in Denmark: implications for depth conversion of maps. AAPG Bulletin 77, 194-211. Tulsa, Oklahoma: American Association of Petroleum Geologists.

Japsen, P. \& Bidstrup, T. 1999: Quantification of late Cenozoic erosion in Denmark based on sonic data and basin modelling. Bulletin of the Geological Society of Denmark 46, 79-99. 
Japsen, P. \& Langtofte, C. 1991: Geological map of Denmark, 1:400 000. The Danish Basin. Danmarks Geologiske UndersøgelseK ortserie 29, 2 pp., 3 maps.

Japsen, P., Bidstrup, T. \& Rasmussen, E.S. 2002: Comment on: "Cenozoic evolution of the eastern Danish North Sea" by M. Huuse, H. Lykke-Andersen and O. Michelsen. Marine Geology 186, 571-575.

Japsen, P., Green, P., Nielsen, L.H., Rasmussen, E.S. \& Bidstrup, T. 2007: Mesozoic-Cenozoic exhumation events in the eastern North Sea Basin: A multi-disciplinary study based on palaeothermal, palaeoburial, stratigraphic and seismic data. Basin Research 19, 451-490.

Jesse, J. 1995: Arkitekturelementanalyse af aflejringer fra den mellem miocæne Odderup Formation. Geologisk Tidsskrift 2, 95 only.

Jørgensen, K.D. 1945: Marint Pliocæn? ved Esbjerg. Meddelelser fra Dansk Geologisk Forening 10, 460-467.

Knox, R. et al. 2010: Cenozoic. In: Doornenbal, J.C. \& Stevenson, A.G. (eds): Petroleum geological atlas of the southern Permian Basin area. Print + DVD. Houten, The Netherlands: EAGE Publications b.v.

Knudsen, C. 1998: Heavy mineral exploration in Miocene sediments, Jylland. Danmarks og Grønlands Geologiske Undersøgelse Rapport 1998/45, 44 pp.

Knudsen, C., Frei, D., Rasmussen, T., Rasmussen, E.S. \& McLimans, R. 2005: New methods in provenance studies based on heavy minerals: an example from Miocene sands in Jylland, Denmark. Geological Survey of Denmark and Greenland Bulletin 7, 29-32.

Koch, B.E. 1989: Geology of the Søby-Fasterholt area. Danmarks Geologiske Undersøgelse Serie A 22, 171 pp. + atlas.

Koch, E. 1977: Stand der geologisch-paläobotanishen Untersuchung miozäner Ablagerungen des zentralen Jütlands, Dänemark. Courier Forschungsinstitut Senckenberg 24, 77-82.

Koch, E. \& Friedrich, W.L. 1970: Geologisch-paläontologische Untersuchung der miozänen Braunkohlen bei Fasterholt in Jütland, Dänemark. Bulletin of the Geological Society of Denmark 20, 169-191.

Koch, E., Friedrich, W.L., Christensen, E.F. \& Friis, E.M. 1973: Den miocæne brunkulsflora og dens geologiske miljø i SøbyFasterholt området sydøst for Herning. Dansk Geologisk Forening Årsskrift 1972, 1-57.

Larsen, G. \& Dinesen, A. 1959: Vejle Fjord Formation ved Brejning: sedimenterne og foraminiferfaunaen (Oligocæn -Miocæn). Danmarks Geologiske Undersøgelse II. Række 82, 114 pp.

Larsen, G. \& Kronborg, C. 1994: Geologisk set: det mellemste Jylland, 272 pp. Odense/København: Geografforlaget, Miljøministeriet \& Skov- og Naturstyrelsen.

Larsson, L.M., Vajda, V. \& Rasmussen, E.S. 2006: Early Miocene pollen and spores from central Jylland, Denmark - environmental and climatic implications. GFF 128, 261-272. Stockholm: Geological Society of Sweden.

Larsson, L.M., Vajda, V. \& Dybkjær, K. 2010: Vegetation and climate in the latest Oligocene - earliest Miocene in Jylland, Denmark. Review of Palaeobotany and Palynology 159, 166-176.
Larsson-Lindgren, L. 2009: Climate and vegetation during the Miocene - evidence from Danish palynological assemblages. $\mathrm{PhD}$ thesis. Litholund theses 19, paper III, $21 \mathrm{pp}$. [unpaginated].

Laursen, G. \& Kristoffersen, F.N. 1999: Detailed foraminiferal biostratigraphy of Miocene formations in Denmark. Contributions to Tertiary and Quaternary Geology 36, 73-107.

Laursen, G.V., Poulsen, N.E. \& Rasmussen. L.B. 1998: Correlation of northwest European Miocene stages with the international stages - preliminary results. Newsletters on Stratigraphy 36(1), $55-61$.

Liboriussen, J., Ashton, P. \& Tygesen, T. 1987: The tectonic evolution of the Fennoscandian Border Zone in Denmark. Tectonophysics $\mathbf{1 3 7}, 21-29$.

Løseth, H. \& Henriksen, S. 2005: A Middle to Late Miocene compression phase along the Norwegian passive margin. In: Doré, A.G. \& Vinding, B.A. (eds): Petroleum geology: NorthWest Europe and global perspectives - Proceedings of the 6th petroleum geology conference, 845-859. London: Geological Society.

Mai, D.B. 1967: Die Florenzonen, der Florenwechsel und die Vorstellung über den Klimaablauf im Jungtertiär der DDR. Abhandlungen Zentral Geologische Institut 10, 55-81.

Martinsen, O.J., Bøen, F., Charnock, M.A., Mangerud, G. \& Nøttvedt, A. 1999: Cenozoic development of the Norwegian margin $60-64^{\circ} \mathrm{N}$ : sequences and sedimentary response to variable basin physiography and tectonic setting. In: Fleet, A.J. \& Boldy, S.A.R. (eds): Petroleum geology of Northwest Europe: Proceedings of the 5th conference, 293-304. London: Geological Society.

Michelsen, O. 1994: Stratigraphic correlation of the Danish onshore and offshore Tertiary successions based on sequence stratigraphy. Bulletin of the Geological Society of Denmark 41, 145-161.

Michelsen, O., Thomsen, E., Danielsen, M., Heilmann-Clausen, C., Jordt, H. \& Laursen, G.V. 1998: Cenozoic sequence stratigraphy in the eastern North Sea. In: De Graciansky, P.C., Jacquin, T. \& Vail, P.R. (eds): Mesozoic and Cenozoic sequence stratigraphy of European basins. Society for Sedimentary Geology (SEPM) Special Publication 60, 91-118.

Miller, K.G., Wright, J.D. \& Fairbanks, R.G. 1991: Unlocking the ice house: Oligocene-Miocene oxygen isotopes, eustasy, and margin erosion. Journal of Geophysical Research 96, 68296848.

Miller, K.G., Mountain, G.S., the Leg 150 Shipboard Party \& members of the New Jersey Coastal Plain Drilling Project 1996: Drilling and dating New Jersey Oligocene-Miocene sequences: ice volume, global sea level, and Exxon records. Science 271, 1092-1095.

Miller, K.G., Mountain, G.S., Browning, J.V., Kominz, M.A., Sugarman, P.J., Christie-Blick, N., Katz, M.E. \& Wright, J.D. 1998: Cenozoic global sea level, sequences and the New Jersey transect: results from coastal plain and continental slope drilling. Review of Geophysics 36, 569-601.

Miller, K.G. et al. 2005: The Phanerozoic record of global sea-level changes. Science 310, 1293-1298. 
Milthers, K. 1949: Nogle hovedlinier i brunkullenes lejringsforhold. Meddelelser fra Dansk Geologisk Forening 11, 486 pp.

Milthers, V. 1939: Beskrivelse til geologisk Kort over Danmark (i Maalestok 1:100.000). Kortbladet Brande. Danmarks Geologiske Undersøgelse I Række 18, 162 pp.

Mogensen, T. \& Jensen, L.N. 1994: Cretaceous subsidence and inversion along the Tornquist Zone from Kattegat to the Egernsund Basin. First Break 12, 211-222.

Møller, L.K., Rasmussen, E.S. \& Clausen, O.R. 2009: Clinoform migration patterns of a Late Miocene delta complex in the Central Graben; implications for relative sea-level changes. In: Henriksen, S. et al. (eds): Trajectory analysis in stratigraphy. Basin Research 21, 704-720.

Mørch, O. 1874: Forhandlingerne ved de skandinaviske Naturforskeres 11te Møde i Kjøbenhavn fra 3die til 9de Juli 1873, 274-298. Kjøbenhavn: Schultz.

Mosar, J., Lewis, G. \& Torsvik, T.H. 2002: North Atlantic sea-floor spreading rates: implication for the Tertiary development of inversion structures of the Norwegian-Greenland Sea. Journal of the Geological Society (London) 159, 503-515.

Muto, T. \& Steel, R.J. 2002: Role of autoretreat and A/S changes in the understanding of deltaic shoreline trajectory: a semi-quantitative approach. Basin Research 14, 303-318.

Olivarius, M. 2009: Provenance and facies of Miocene sand successions in western Denmark based on bulk geochemistry, heavy minerals and zircon age datings, $90 \mathrm{pp}$. [unpaginated]. Unpublished MSc thesis, University of Copenhagen, Denmark.

Oszczypko, N. 2006: Late Jurassic-Miocene evolution of the outer Carpatian fold-and-thrust belt and its foredeep basin (Western Carpatians, Poland). Geological Quarterly 50, 169-194.

Piasecki, S. 1980: Dinoflagellate cyst stratigraphy of the Miocene Hodde and Gram Formations, Denmark. Bulletin of the Geological Society of Denmark 29, 53-76.

Piasecki, S. 2005: Dinoflagellate cysts of the Middle-Upper Miocene Gram Formation, Denmark. In: Roth, F. \& Hoedemarkers, K. (eds): The Gram book. Palaeontos 7, 143-155.

Piasecki, S., Rasmussen, E.S. \& Dybkjær, K. 2003: Neogene sedimenter ved Sjælborg og Marrebæk Klint, Esbjerg, Vestjylland. Danmarks og Grønlands Geologiske Undersøgelse Rapport 2003/83, 18 pp.

Pontén, A. \& Plink-Björklund, P. 2007: Depositional environments in an extensive tide-influenced plain, Middle Devonian Gauja Formation, Devonian Baltic. Sedimentology 54, 969-1006.

Potter, P.E. \& Szatmari, P. 2009: Global Miocene tectonics and the modern world. Earth-Science Reviews 96, 279-295.

Prentice, M.L. \& Matthews, R.K. 1988: Cenozoic ice-volume history: development of a composite oxygen isotope record. Geology 16, 963-966.

Radwanski, A., Friis, H. \& Larsen, G. 1975: The Miocene Hagenør-Børup sequence at Lillebælt (Denmark): its biogenic structures and depositional environment. Bulletin of the Geological Society of Denmark 24, 229-260.

Rasmussen, E.S. 1987: En mineralogisk og geokemisk undersøgelse af Vejle Fjord Formationen (Ø. Oligocæn - N. Miocæn), 223 pp. Unpublished cand. scient. thesis, Aarhus Universitet, Danmark.
Rasmussen, E.S. 1995: Vejle Fjord Formation: clay mineralogy and geochemistry. Bulletin of the Geological Society of Denmark $\mathbf{4 2}$, 57-67.

Rasmussen, E.S. 1996: Sequence stratigraphic subdivision of the Oligocene and Miocene succession in South Jylland. Bulletin of the Geological Society of Denmark 43, 143-155.

Rasmussen, E.S. 2004a: The interplay between true eustatic sealevel changes, tectonics, and climatical changes: What is the dominating factor in sequence formation of the Upper Oligocene-Miocene succession in the eastern North Sea Basin, Denmark? Global and Planetary Changes 41, 15-30.

Rasmussen, E.S. 2004b: Stratigraphy and depositional evolution of the uppermost Oligocene - Miocene succession in Denmark. Bulletin of the Geological Society of Denmark 51, 89-109.

Rasmussen, E.S. 2005: The geology of the upper Middle - Upper Miocene Gram Formation in the Danish area. In: Roth, F. \& Hoedemarkers, K. (eds): The Gram book. Paleontos 7, 5-18.

Rasmussen, E.S. 2009a: Neogene inversion of the north-eastern North Sea. Tectonophysic 465, 84-97.

Rasmussen, E.S. 2009b: Detailed mapping of marine erosional surfaces and the geometry of clinoforms on seismic data: a tool to identify the thickest reservoir sand. In: Henriksen, S. et al. (eds): Trajectory analysis in stratigraphy. Basin Research 21, 721-737.

Rasmussen, E.S. \& Dybkjær, K. 2005: Sequence stratigraphy of the Upper Oligocene - Lower Miocene of eastern Jylland, Denmark: role of structural relief and variable sediment supply in controlling sequence development. Sedimentology 52, 25-63.

Rasmussen, E.S. \& Larsen, O.H. 1989: Mineralogi og geokemi i det Øvre Miocæne Gram ler. Danmarks Geologiske Undersøgelse Serie D 7, 81 pp.

Rasmussen, E.S., Vejbæk, O.V., Bidstrup, T., Piasecki, S. \& Dybkjær, K. 2005: Late Cenozoic depositional history of the Danish North Sea Basin: implications for the petroleum systems in the Kraka, Halfdan, Siri and Nini fields. In: Doré, A.G. \& Vining, B.A. (eds): Petroleum geology: North-West Europe and global perspectives. Proceedings of the 6th Petroleum Geology Conference I, 1347-1358. London: Geological Society.

Rasmussen, E.S., Dybkjær, K. \& Piasecki, S. 2006: Neogene fluvial and marginal marine deposits of the Salten section, Denmark. Bulletin of the Geological Society of Denmark 53, 23-37.

Rasmussen, E.S., Vangkilde-Pedersen, T. \& Scharling, P. 2007: Prediction of reservoir sand in Miocene deltaic deposits in Denmark based on high-resolution seismic data. Geological Survey of Denmark and Greenland Bulletin 13, 17-20.

Rasmussen, E.S., Heilmann-Clausen, C., Waagstein, R. \& Eidvin, T. 2008: Tertiary of Norden. Episodes 31, 66-72.

Rasmussen, L.B. 1956: The marine Upper Miocene of South Jutland and its molluscan fauna. Danmarks Geologiske Undersøgelse II. Række 81, 166 pp.

Rasmussen, L.B. 1958: Det marine ungtertiær ved Sæd. Meddelelser fra Dansk Geologisk Forening 14, 1-28.

Rasmussen, L.B. 1961: De Miocæne formationer i Danmark. Danmarks Geologiske Undersøgelse IV Række 5, 45 pp.

Rasmussen, L.B. 1966: Biostratigraphical studies on the marine 
younger Miocene of Denmark. Based on the molluscan faunas. Danmarks Geologiske Undersøgelse II. Række 88, 358 pp.

Rasmussen, L.B. 1968: Molluscan faunas and biostratigraphy of the marine younger Miocene formations in Denmark. Part II: Palaeontology. Danmarks Geologiske Undersøgelse II. Række 92, 265 pp.

Rasmussen, L.B. 1975: Tertiærperioden. In: Nørrevang, A. \& Meyer, T.J. (eds): Danmarks natur I, 161-198. København: Politikens Forlag.

Rasmussen, L.B. 1988: En jordisk krønike. Træk af DGUs historie 1888-1988, 114 pp. København: Danmarks Geologiske Undersøgelse.

Rasser, M.W. et al. 2008: Palaeogene and Neogene. In: McCann, T. (ed.): The geology of central Europe 2: Mesozoic and Cenozoic, 1031-1138. London: Geological Society.

Ravn, J.P.J. 1906: Nogle Bemærkninger om de Oligocæne og Miocæne Aflejringer i Jylland. Meddelelser fra Dansk Geologisk Forening 12, 1-6.

Ravn, J.P.J. 1907: Molluskfaunaen i Jyllands Tertiæraflejringer. Det Kongelige Danske Videnskabernes Selskabs Skrifter Række 7. Naturvidenskablige og Mathematiske Afdeling III(2), 217-385.

Ribero, A., Kullberg, M.C., Kullberg, J.C., Manuppellea, G. \& Pripps, S. 1990: A review of Alpine tectonics in Portugal: foreland detachment and cover rocks. Tectonophysics 184, 357-366.

Rundberg, Y. \& Eidvin, T. 2005: Controls on depositional history and architecture of the Oligocene-Miocene succession, northern North Sea Basin. In: Wandaas, B.T.G. et al. (eds): Onshore -offshore relationships on the North Atlantic margin. NPF Special Publication 12, 207-239. Amsterdam: Elsevier.

Salvador, A. 1994: International stratigraphic guide. A guide to stratigraphic classification, terminology, and procedure. Second edition, 214 pp. Boulder: Geological Society of America Inc.

Schiøler, P. et al. 2007: Lithostratigraphy of the Palaeogene - Lower Neogene succession of the Danish North Sea. Geological Survey of Denmark and Greenland Bulletin 12, 77 pp.

Schnetler, K.I. 2005: The mollusca from the stratotype of the Gram Formation (Late Miocene, Denmark). Roth, F. \& Hoedemarkers, K. (eds): The marine Gram Formation at Gram, Denmark: Late Miocene geology and palaeontology. Palaeontos 7, 62-189.

Schnetler, K.I. \& Beyer, C. 1987: A late Chattian (Chattian B) mollusc fauna from the clay-pit of Galten brickworks at Nørre Vissing, Jylland, Denmark. Mededelingen van de Werkgroep voor Tertiaire en Kwartaire Geologie (Contributions to Tertiary and Quaternary Geology) 24, 193-224.

Schnetler, K.I. \& Beyer, C. 1990: A Late Oligocene (Chattian B) molluscan fauna from the coastal cliff at Mogenstrup, North of Skive, Jutland, Denmark. Contributions to Tertiary and Quatenary Geology 27, 39-81.

Sorgenfrei, T. 1940: Marint Nedre-Miocæn i Klintinghoved paa Als. Danmarks Geologiske Undersøgelse II. Række 65, 143 pp.

Sorgenfrei, T. 1957: Formations of Denmark. In: Pruvost, P. (ed.): Lexique Stratigraphique International 1(2d), 44 pp.

Sorgenfrei, T. 1958: Molluscan assemblages from the marine Middle Miocene of South Jutland and their environments. Danmarks Geologiske Undersøgelse II. Række 79, 503 pp.
Sorgenfrei, T. \& Berthelsen, A. 1954: Geology and water well boring. Danmarks Geologiske Undersøgelse III. Række 31, 106 pp.

Spjeldnæs, N. 1975: Palaeogeography and facies distribution in the Tertiary of Denmark and surrounding areas. Norges Geologiske Undersøkelse 316, 289-311.

Steeman, M.E. 2009: A new baleen whale from the Late Miocene of Denmark and early mysticete hearing. Palaeontology 52, 11691190.

Ulleberg, K. 1987: Foraminiferal zonation of the Danish Oligocene sediments. Bulletin of the Geological Society of Denmark 36, 191-202.

Ulleberg, K. 1994: Oligocene foraminifera and stratigraphy from the Harre borehole, Denmark. Aarhus Geoscience 1, 81-83. Aarhus, Denmark: University of Aarhus.

Utescher, T., Mosbrugger, V. \& Ashraf, A.R. 2000: Terrestrial climate evolution in Northwest Germany over the last 25 million years. Palaios 15, 430-449.

Utescher, T., Mosbrugger, V., Ivanov, D. \& Dilcher, D.L. 2009: Present-day climatic equivalents of European Cenozoic climates. Earth and Planetary Science Letters 284, 544-552.

Vejbæk, O.V. 1992: Geodynamic modelling of the Danish Central Trough. In: Larsen, R.M. et al. (eds): Structural and tectonic modelling and its application to petroleum geology. Norwegian Petroleum Society, Special Publication 1, 1-17. Amsterdam: Elsevier.

Vejbæk, O.V. 1997: Dybe strukturer i danske sedimentære bassiner. Geologisk Tidsskrift 4, 1-31.

Vejbæk, O.V. \& Andersen, C. 2002: Post mid-Cretaceous inversion tectonics in the Danish Central Graben - regionally synchronous tectonic events. Bulletin of the Geological Society of Denmark 49, 139-144.

von Salis, K. 1993: First Oligocene silicoflagellates from N. Europe (Silstrup, Denmark). Zitteliana 20, 79-86.

von Salis Perch-Nielsen, K. 1994: Neogene and Paleogene calcareous nannofossils from the Harre borehole, Denmark. In: Nielsen, O.B. (ed.): Lithostratigraphy and biostratigraphy of the Tertiary sequence from the Harre borehole, Denmark. Aarhus Geoscience 1, 45-51. Aarhus, Denmark: University of Aarhus.

Wagner, P. \& Koch, B.E. 1974: Fossil roots of Sequoia type from two localities of the Miocene delta deposits of the Søby area. Geological Society of Denmark Bulletin 23, 134-158.

Weibel, R. 1996: Petrified wood from an unconsolidated sediment, Voervadsbro, Denmark. Sedimentary Geology 101, 31-41.

Zachos, J., Pagani, M., Sloan, L., Thomas, E. \& Billups, K. 2001: Trends, rhythms, and aberrations in global climate $65 \mathrm{Ma}$ to Present. Science 292, 686-693.

Ziegler, P.A. 1982: Geological atlas of western and central Europe, 130 pp. The Hague: Shell Internationale Petroleum Maatschappij B.V.

Ziegler, P.A. 1990: Geological atlas of western and central Europe, 2nd edition, 239 pp. The Hague: Shell Internationale Petroleum Maatschappij B.V.

Ziegler, P.A., Cloetingh, S. \& van Wees, J.D. 1995: Geodynamics of intraplate compressional deformation: the Alpine foreland and other examples. Tectonophysics 252, 7- 59 . 



\section{De Nationale Geologiske Undersøgelser for Danmark og Grønland (GEUS) Geological Survey of Denmark and Greenland Øster Voldgade 10, DK-1350 Copenhagen K Denmark}

The series Geological Survey of Denmark and Greenland Bulletin started in 2003 and replaced the two former bulletin series of the Survey, viz. Geology of Greenland Survey Bulletin and Geology of Denmark Survey Bulletin. Some of the twenty-one volumes published since 1997 in those two series are listed on the facing page. The present series, together with Geological Survey of Denmark and Greenland Map Series, now form the peer-reviewed scientific series of the Survey.

\section{Geological Survey of Denmark and Greenland Bulletin}

1 The Jurassic of Denmark and Greenland, 948 pp. (28 articles), 2003. Edited by J.R. Ineson \& F. Surlyk.

2 Fish otoliths from the Paleocene of Denmark, 94 pp., 2003. By W. Schwarzhans.

100.00

3 Late Quaternary environmental changes recorded in the Danish marine molluscan faunas, 268 pp., 2004. By K.S. Pedersen.

6 East Greenland Caledonides: stratigraphy, structure and geochronology, 93 pp. (6 articles), 2004. Edited by A.K. Higgins and F. Kalsbeek.

7 Review of Survey activities 2004, 80 pp. (19 articles), 2005. Edited by M. Sønderholm \& A.K. Higgins.

180.00

8 Structural analysis of the Rubjerg Knude Glaciotectonic Complex, Vendsyssel, northern Denmark, 192 pp., 2005. By S.A.S. Pedersen.

300.00

9 Scientific results from the deepened Lopra-1 borehole, Faroe Islands, 156 pp. (11 articles), 2006. Edited by J.A. Chalmers \& R. Waagstein.

10 Review of Survey activities 2005, 68 pp. (15 articles), 2006. Edited by M. Sønderholm \& A.K. Higgins.

11 Precambrian crustal evolution and Cretaceous-Palaeogene faulting in West Greenland, 204 pp. (12 articles), 2006. Edited by A.A. Garde \& F. Kalsbeek.

12 Lithostratigraphy of the Palaeogene - Lower Neogene succession of the Danish North Sea, 77 pp., 2007. By P. Schiøler, J. Andsbjerg, O.R. Clausen, G. Dam, K. Dybkjær, L. Hamberg, C. Heilmann-Clausen, E.P. Johannessen, L.E. Kristensen, I. Prince \& J.A. Rasmussen. Review of Survey activities 2006, 76 pp. (17 articles), 2007. Edited by M. Sønderholm \& A.K. Higgins.

14 Quaternary glaciation history and glaciology of Jakobshavn Isbræ and the Disko Bugt region, West Greenland: a review, 78 pp., 2007. By A. Weidick \& O. Bennike.

16 Evaluation of the quality, thermal maturity and distribution of potential source rocks in the Danish part of the Norwegian-Danish Basin, 66 pp., 2008. By H.I. Petersen, L.H. Nielsen, J.A. Bojesen-Koefoed,

A. Mathiesen, L. Kristensen \& F. Dalhoff.

18 Greenland from Archaean to Quaternary. Descriptive text to the 1995 Geological map of Greenland, 1:2 500 000.2nd edition, 126 pp., 2009. By N. Henriksen, A.K. Higgins, F. Kalsbeek \& T.C.R. Pulvertaft.

19 Lithostratigraphy of the Cretaceous-Paleocene Nuussuaq Group, Nuussuaq Basin, West Greenland, 171 pp., 2009. By G. Dam, G.K. Pedersen, M. Sønderholm, H.H. Midtgaard, L.M. Larsen, H. Nøhr-Hansen \& A.K. Pedersen. 


\section{Geological Survey of Denmark and Greenland Map Series}

1 Explanatory notes to the Geological map of Greenland, 1:500 000, Humboldt Gletscher, Sheet 6, 48 pp., 2004. By P.R. Dawes

2 Explanatory notes to the Geological map of Greenland, 1:500 000, Thule, Sheet 5 (1991),

97 pp. + map, 2006. By P.R. Dawes.

3 Explanatory notes to the Geological map of Greenland, 1:100 000, Ussuit 67 V.2 Nord,

40 pp. + map, 2007. By J.A.M. van Gool \& M. Marker.

4 Descriptive text to the Geological map of Greenland, 1:500 000, Dove Bugt, Sheet 10,

32 pp. + map, 2009. By N. Henriksen \& A.K. Higgins

5 Descriptive text to the Geological map of Greenland, 1:100 000, Kangaatsiaq 68 V.1 Syd and Ikamiut 68 V.1 Nord, 41 pp. +2 maps, 2010. By A.A. Garde \& J.A. Hollis.

\section{Geology of Greenland Survey Bulletin (discontinued)}

179 The Citronen Fjord massive sulphide deposit, Peary Land, North Greenland: discovery, stratigraphy, mineralization and structural setting, 40 pp., 1998. By F.W. van der Stijl \& G.Z. Mosher.

180 Review of Greenland activities 1997, 176 pp. (26 articles), 1998. Edited by A.K. Higgins \& W.S. Watt.

181 Precambrian geology of the Disko Bugt region, West Greenland, 179 pp. (15 articles), 1999.

Edited by F. Kalsbeek.

182 Vertebrate remains from Upper Silurian - Lower Devonian beds of Hall Land, North Greenland,

80 pp., 1999. By H. Blom.

183 Review of Greenland activities 1998, 81 pp. (10 articles), 1999. Edited by A.K. Higgins \& W.S. Watt.

184 Collected research papers: palaeontology, geochronology, geochemistry, 62 pp. (6 articles), 1999.

185 Greenland from Archaean to Quaternary. Descriptive text to the Geological map of Greenland, 1:2 500 000, 93 pp., 2000. By N. Henriksen, A.K. Higgins, F. Kalsbeek \& T.C.R. Pulvertaft.

186 Review of Greenland activities 1999, 105 pp. (13 articles), 2000. Edited by P.R. Dawes \& A.K. Higgins.

187 Palynology and deposition in the Wandel Sea Basin, eastern North Greenland, 101 pp. (6 articles), 2000.

160.00

188 The structure of the Cretaceous-Palaeogene sedimentary-volcanic area of Svartenhuk Halvø, central West Greenland, 40 pp., 2000. By J. Gutzon Larsen \& T.C.R. Pulvertaft.

189 Review of Greenland activities 2000, 131 pp. (17 articles), 2001. Edited by A.K. Higgins \& K. Secher.

190 The Ilímaussaq alkaline complex, South Greenland: status of mineralogical research with new results, 167 pp. (19 articles), 2001. Edited by H. Sørensen.

191 Review of Greenland activities 2001, 161 pp. (20 articles), 2002.

Edited by A.K. Higgins, K. Secher \& M. Sønderholm.

\section{Geology of Denmark Survey Bulletin (discontinued)}

36 Petroleum potential and depositional environments of Middle Jurassic coals and non-marine deposits, Danish Central Graben, with special reference to the Søgne Basin, 78 pp., 1998.

By H.I. Petersen, J. Andsbjerg, J.A. Bojesen-Koefoed, H.P. Nytoft \& P. Rosenberg.

37 The Selandian (Paleocene) mollusc fauna from Copenhagen, Denmark: the Poul Harder 1920 collection, 85 pp., 2001. By K.I. Schnetler. 
